\title{
The paleolimnology of \\ Haynes Lake, and Teapot Lake, Ontario: \\ documenting anthropogenic disturbances within \\ Canada's largest city
}

By

Melissa A. Watchorn

A thesis submitted to the Faculty of Graduate Studies and Research in partial fulfillment of the requirements for the degree of

Master of Science

Department of Earth Sciences and

Ottawa-Carleton Geoscience Centre

Carleton University,

Ottawa, Ontario

April 7, 2008

(C) 2008, Melissa A. Watchorn 


$\begin{array}{ll}\begin{array}{l}\text { Library and } \\ \text { Archives Canada }\end{array} & \begin{array}{l}\text { Bibliothèque et } \\ \text { Archives Canada }\end{array} \\ \begin{array}{l}\text { Published Heritage } \\ \text { Branch }\end{array} & \begin{array}{l}\text { Direction du } \\ \text { Patrimoine de l'édition }\end{array} \\ \begin{array}{l}\text { 395 Wellington Street } \\ \text { Ottawa ON K1A 0N4 } \\ \text { Canada }\end{array} & \begin{array}{l}\text { 395, rue Wellington } \\ \text { Ottawa ON K1A 0N4 } \\ \text { Canada }\end{array}\end{array}$

Your file Votre référence

ISBN: 978-0-494-40663-2

Ourfile Notre référence

ISBN: 978-0-494-40663-2

NOTICE:

The author has granted a nonexclusive license allowing Library and Archives Canada to reproduce, publish, archive, preserve, conserve, communicate to the public by telecommunication or on the Internet, loan, distribute and sell theses worldwide, for commercial or noncommercial purposes, in microform, paper, electronic and/or any other formats.

The author retains copyright ownership and moral rights in this thesis. Neither the thesis nor substantial extracts from it may be printed or otherwise reproduced without the author's permission.
AVIS:

L'auteur a accordé une licence non exclusive permettant à la Bibliothèque et Archives Canada de reproduire, publier, archiver, sauvegarder, conserver, transmettre au public par télécommunication ou par l'Internet, prêter, distribuer et vendre des thèses partout dans le monde, à des fins commerciales ou autres, sur support microforme, papier, électronique et/ou autres formats.

L'auteur conserve la propriété du droit d'auteur et des droits moraux qui protège cette thèse. $\mathrm{Ni}$ la thèse ni des extraits substantiels de celle-ci ne doivent être imprimés ou autrement reproduits sans son autorisation.
In compliance with the Canadian Privacy Act some supporting forms may have been removed from this thesis.

While these forms may be included in the document page count, their removal does not represent any loss of content from the thesis.
Conformément à la loi canadienne sur la protection de la vie privée, quelques formulaires secondaires ont été enlevés de cette thèse.

Bien que ces formulaires aient inclus dans la pagination, il n'y aura aucun contenu manquant.

\section{Canada}




\section{Acknowledgements and Contributions}

This research was a collaborative effort between myself and several other people, without whom, this work would not exist. This project began in 2005 when field work was completed with the assistance of Dr. R. Timothy Patterson, Cherylee Black, Davin Carter, and Dr. Bob Boudreau, all from Carleton University, Dr. Ian Clark, and Tina Ziten from the University of Ottawa, and Dr. Helen M. Roe from Queen's University of Belfast. Subsequent field work in Teapot Lake and Haynes Lake were completed in 2006 with Tina Ziten and Paul Hamilton and, again, in 2007 with Paul Hamilton. This research was supported by a NSERC Discover Grant and funding from the Toronto and Region Conservation Authority (TRCA) to Tim Patterson.

I would like to acknowledge the contribution of Dave Mans and Aaron Phillips, both Carleton University Earth Sciences Graduate students, who provided all of the raw thecamoebian data that was used in the Haynes Lake study. I would also like to acknowledge the contribution of Dr. Jennifer M. Galloway, a former Carleton University Earth Sciences Graduate student, who provided the pollen data and analysis thereof, for the Teapot Lake study. The Northwest Territories Geoscience Office in Yellowknife provided the microscope and camera used for the palynological analysis.

Many thanks go to Mark Nixon, from the Geological Survey of Canada (GSC), for allowing use of the temperature data loggers, and recovering the data from them. 
Also thank you to Dr. Roger McNeely, for coordinating contact between the GSC and me, and for his words of wisdom.

I would like to express my most sincere thanks to Paul Hamilton, from the Canadian Museum of Nature for his endless support, guidance, expertise and collaboration. I would also like to thank Tim Patterson for his support and guidance throughout this project. Many thanks also to the Canadian Museum of Nature for allowing my use of space and laboratory equipment.

Lastly, I would like to thank my family for their patience and understanding throughout this process. 


\section{Chapter 1. General Introduction}

At Carleton University, students are encouraged to publish the results of their research. Therefore, a thesis can be formatted as a manuscript at the outset, to ease the process of submission to a scientific journal. As a result, this thesis has been formatted so that two journal articles can be extracted and published. The first, a study of Haynes Lake, Ontario (Chapter 2), will be submitted to "Environmental Geology" and the second, a study of Teapot Lake, Ontario (Chapter 3) will be submitted to "Hydrobiologia".

The human ecological footprint is a method of measuring anthropogenic impacts to ecosystems. The Greater Toronto Area (GTA) has been drastically changed since humans have settled in the area, and, therefore this area scores very high

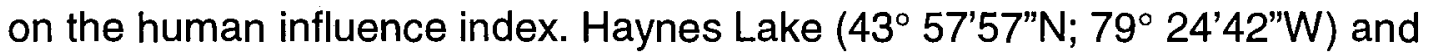
Teapot Lake $\left(43^{\circ} 45^{\prime} 14^{\prime \prime} \mathrm{N} ; 79^{\circ} 48^{\prime} 14^{\prime \prime} \mathrm{W}\right)$ were the focus of this research given their location within the GTA, and their close proximity to Swan Lake $\left(43^{\circ}\right.$ $\left.57^{\prime} 00^{\prime \prime} \mathrm{N} ; 7^{\circ} 24^{\prime} 51^{\prime \prime} \mathrm{W}\right)$, Ontario, and the subject of my undergraduate research project. Haynes Lake, like Swan Lake, is located on the Oak Ridges Moraine (ORM), an area recognized for containing an important source of ground water

for the Greater Toronto Area (GTA), and also one that is biologically diverse. The purpose of this research is to study anthropogenic and natural stressors on Haynes Lake, and evaluate the degree of change that may have occurred with the movement of the human species into the region, using diatoms and thecamoebians extracted from lake sediments as the biological proxy. Further, I 
evaluated if similar anthropogenic changes to the landscape clearly evident in the Swan Lake aquatic ecosystem were also evident in Haynes Lake.

Although Teapot Lake is not located on the ORM, it is also located within the GTA. Visual inspection of water property data from Teapot Lake indicated the lake may be meromictic, and might therefore provide a detailed record of the history of the lake. The land surrounding Teapot Lake, except for a small, thick screen of forest, has been subjected to clearance first for agriculture and housing for European settlers, and, more recently, for many highways and housing to accommodate explosive population growth in the area. Therefore, Teapot Lake was studied to determine if anthropogenic changes to the landscape, confirmed through palynology, could be detected in the aquatic ecosystem, also using diatoms as the biological proxy, and if so, were these changes similar to changes observed in Haynes Lake and in Swan Lake.

The results of these studies indicate that Haynes Lake showed evidence of similar impacts to the aquatic ecosystem as were observed in the Swan Lake study. Both lakes indicated that anthropogenic alterations of the landscape had an impact on the aquatic ecosystem. Conversely, the results of the Teapot Lake study did not show significant changes in the aquatic ecosystem using diatoms as the biological proxy even though it was shown that the lake is meromictic, and therefore the sediments should provide an accurate record of changes to the lake concomitant with anthropogenic stresses. It is hypothesized that either the 
sediments have been disturbed when the massive roadways were constructed or repaired nearby, or phosphorus is not biologically available for diatom growth due to the meromictic nature of the lake. 


\section{Table of Contents}

Acknowledgements and Contributions.......................................................... 1

Chapter 1. General Introduction .................................................................... 3

List of Figures and Tables....................................................................... 8

Chapter 2. The paleolimnology of Haynes Lake, Oak Ridges Moraine, Ontario: documenting 700 years of anthropogenic disturbance ..................................... 9

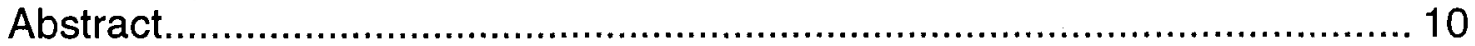

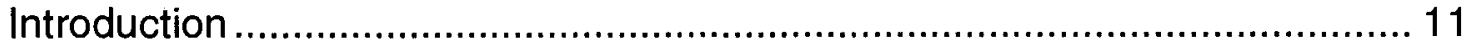

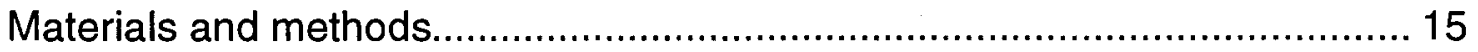

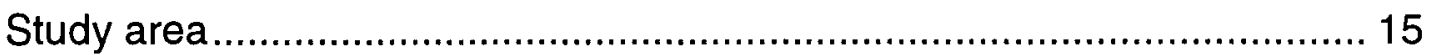

Sediment Core Details and Chronology ................................................ 17

Diatom Preparation and Enumeration .................................................... 19

Thecamoebian Preparation and Enumeration ........................................ 21

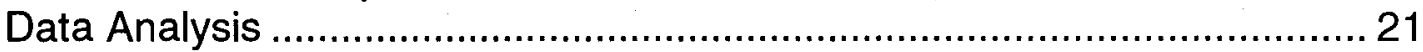

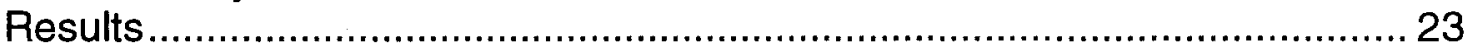

Sediment Core Details and Chronology …............................................. 23

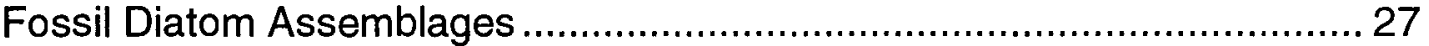

Diatom-inferred pH (DI-pH) and Total Phosporus (DI-TP) .......................... 28

Fossil Thecamoebian Assemblages........................................................ 31

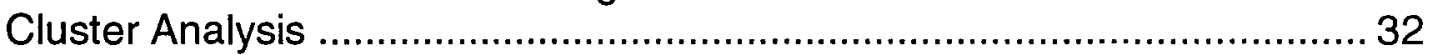

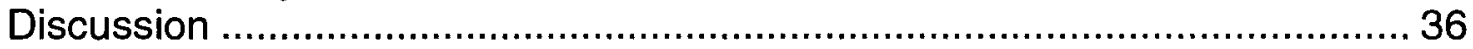

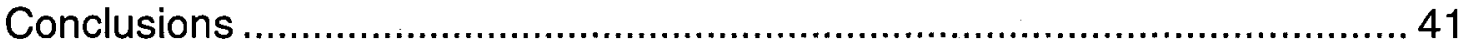

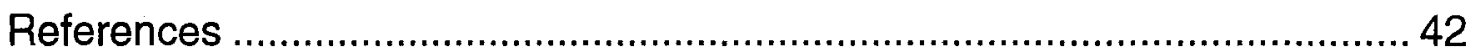

Chapter 3. A paleolimnological study of meromictic Teapot Lake, Ontario ........50

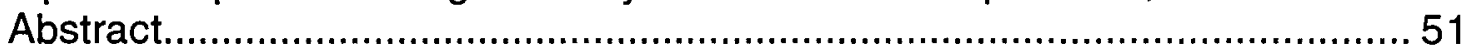

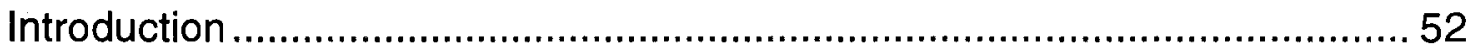

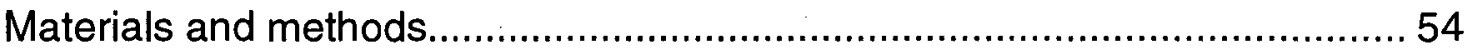

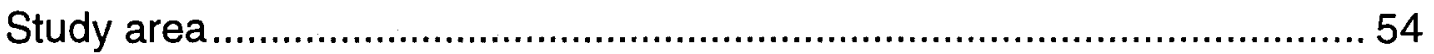

Sedimentology and sediment core details............................................5 57

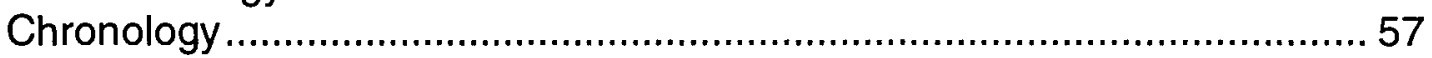

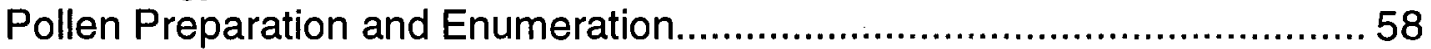

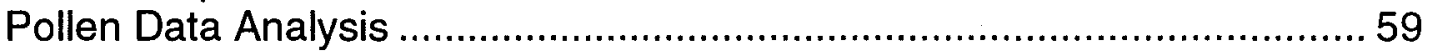

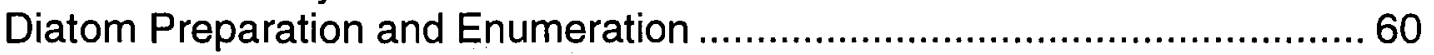

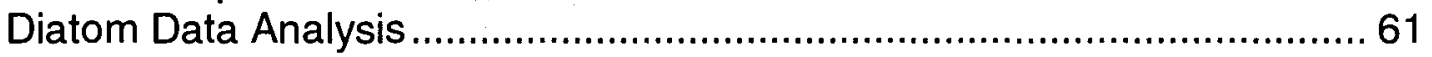

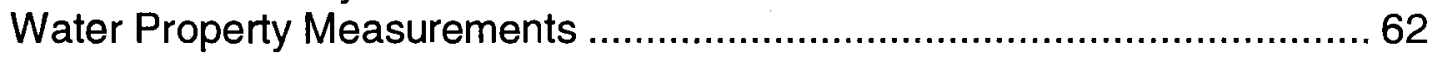

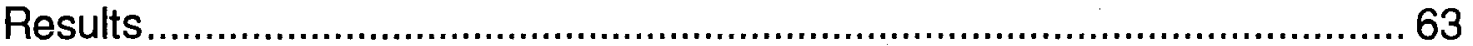

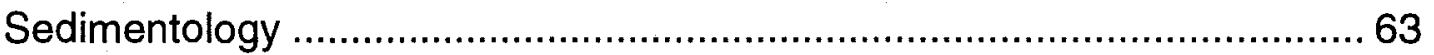

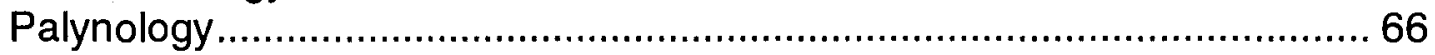

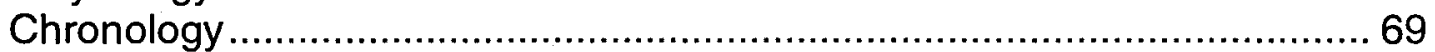

Water Properties and Physical Characteristics of Teapot Lake.................. 73

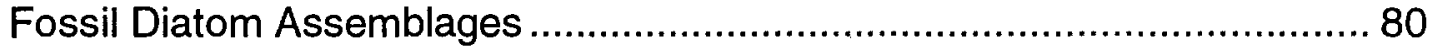

Diatom-inferred pH and Total Phosphorus (DI-pH and DI-TP) .................. 83

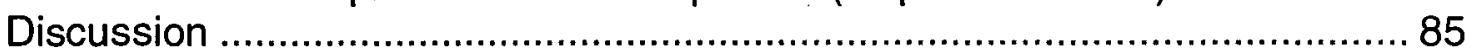

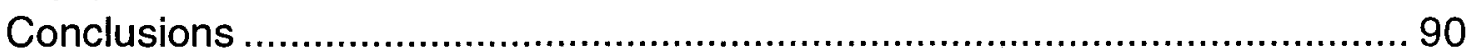

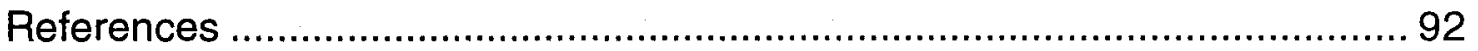


Appendix 1. Diatom percent abundance data: Haynes Lake, Ontario ............... 98

Appendix 2. Haynes Lake Diatom Subsampling Data .................................... 104

Appendix 3. Thecamoebian percent abundance data: Haynes Lake, Ontario.. 105

Appendix 4. Haynes Lake ${ }^{210} \mathrm{~Pb}$ data ........................................................ 106

Appendix 5. Haynes Lake Water Chemistry Data ...................................... 107

Appendix 6. Common diatom species images: Haynes Lake, Ontario ............. 108

Appendix 7. Sediment core x-ray images: Haynes Lake, Ontario .................... 112

Appendix 8. Diatom percent abundance data: Teapot Lake, Ontario .............. 114

Appendix 9. Teapot Lake Diatom Subsampling Data .................................... 126

Appendix 10. Pollen percent abundance data: Teapot Lake, Ontario .............. 128

Appendix 11. Teapot Lake ${ }^{210} \mathrm{~Pb}$ data ....................................................... 136

Appendix 12. Common diatom species images: Teapot Lake, Ontario ............ 137

Appendix 13. Sediment core x-ray images: Teapot Lake, Ontario ................... 141 


\section{List of Figures and Tables}

\section{Chapter 2 Figures and Tables}

Fig. 1. Site Map of Haynes Lake, Ontario, Canada ....................................... 16

Fig. 2A. Haynes Lake Core $x$-ray: $0-20 \mathrm{~cm}$ depth from core HYC1-1.......... 24

Fig. 2B. Haynes Lake Core $x$-ray: $14-34 \mathrm{~cm}$ depth from core HYC1-1......... 24

Fig. 2C. Haynes Lake Core $x$-ray: $54-74 \mathrm{~cm}$ depth from Core HYC1-1........ 24

Fig. 2D. Haynes Lake Core $x$-ray: $114-134 \mathrm{~cm}$ depth from core HYC1-2..... 25

Fig. 2E. Haynes Lake Core x-ray: $134-154 \mathrm{~cm}$ depth from core HYC1-2..... 25

Fig. 3. Graph of Haynes Lake sediment age .............................................. 26

Fig. 4. Diatom percent abundance, DI-TP, and DI-pH from Haynes Lake, Ontario.

Fig. 5. Thecamoebian percent abundance from Haynes Lake, Ontario. ............ 33

Fig. 6. Cluster analysis of diatom species percent abundance from Haynes Lake,

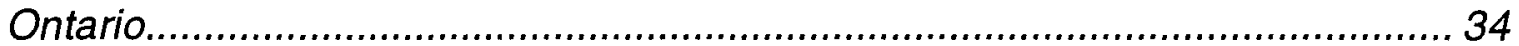

Fig. 7. Cluster analysis of thecamoebian species percent abundance from

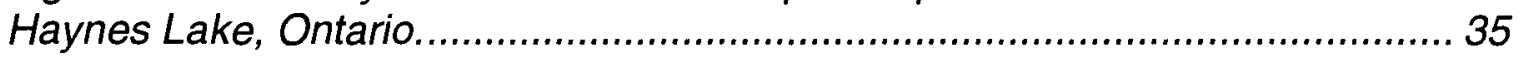

\section{Chapter 3 Figures and Tables}

Fig. 1. Site map of Teapot Lake, Ontario, Canada........................................ 56

Fig. 2A. Teapot Lake Core $x$-ray: $20-40 \mathrm{~cm}$ depth from core TPLC2-1....... 64

Fig. 2B. Teapot Lake core x-ray: $130-150 \mathrm{~cm}$ depth from core TPLC2-2..... 64

Fig. 2C. Teapot Lake Core $x$-ray: $180-206 \mathrm{~cm}$ depth from core TPLC2-2.... 64

Fig. 2D. Teapot Lake Core $x$-ray: $285-305 \mathrm{~cm}$ depth from core TPLC2-3..... 65

Fig. 2E. Teapot Lake Core $x$-ray: $~ 335-355 \mathrm{~cm}$ depth from core TPLC2-4 .... 65

Fig. 2F. Teapot Lake core x-ray: 375 - $395 \mathrm{~cm}$ depth from core TPLC2-4...... 65

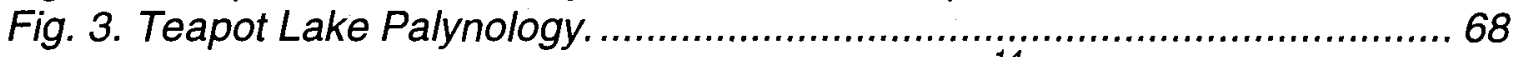

Table 1. Teapot Lake Sediment and Wood Fragment ${ }^{14} \mathrm{C}$ Dating Results .......... 70

Fig. 4A. Graph of Teapot Lake sediment age using ${ }^{210} \mathrm{~Pb}$ dating methods. ...... 71

Fig. 4B. Graph of Teapot Lake sediment age using ${ }^{210} \mathrm{~Pb}$ and palynology ........ 72

Table 2. Teapot Lake Water Property Profile, August 17, 2005 ...................... 77

Table 3. Teapot Lake Water Property Values............................................. 77

Fig. 5. Graph of Teapot Lake Water Temperatures from April 21, 2006 to March

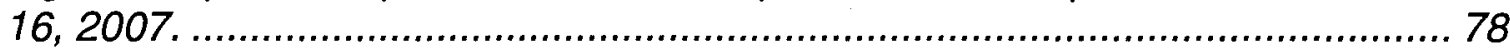

Fig. 6. Sub-bottom profiles of Teapot Lake, Ontario..................................... 79

Fig. 7. Diatom percent abundance, DI-TP, and DI-pH from Teapot Lake, Ontario. 81

Fig. 8. Cluster analysis of diatom species percent abundance from Teapot Lake, Ontario. 84 
Chapter 2. The paleolimnology of Haynes Lake, Oak Ridges Moraine, Ontario: documenting 700 years of anthropogenic disturbance 


\section{Abstract}

Haynes Lake is a small kettle lake located on the Oak Ridges Moraine (ORM), Ontario, and is within the Greater Toronto Area (GTA); Canada's most populous region. The ORM is an important recharge and discharge area for ground water and drinking water in the GTA, and is a natural habitat for a diverse array of plant and animal species. Diatoms and thecamoebians extracted from Haynes Lake sediment cores were used as biological proxies to quantify changes in water chemistry through time, and thus infer changes in the limnology and ecosystem biology. High-resolution details of the sedimentary history of the lake were determined through $\mathrm{x}$-ray analysis of the sediment cores. There were three periods of disturbance to the Haynes Lake ecosystem from ca A.D. 656 through to $c a$ A.D. 2003 which were significant enough to cause major changes in lake sedimentation, the diatom flora, and thecamoebian fauna. The first disturbance was concomitant with Iroquoian population expansion in the area during the period from A.D. 1300 to A.D. 1550 . The second period of disturbance occurred between ca. A.D. 1670 - 1750 following the first appearance of European settlers in the area. The most severe disturbance to the ecosystem, however, occurred ca A.D. 1890 due to increased erosion caused by a growing population of European settlers in the vicinity who cleared land for agriculture, housing and built a road adjacent to the lake. 


\section{Introduction}

The global human footprint is expressed as the sum total of all ecological footprints of the human population (human influence index (HII)), and has been estimated to cover $83 \%$ of the earth's landmass (Sanderson et al. 2002). Scoring $\sim 60 \%$ on the HII, it would be expected that heavily populated and industrialized southern Ontario, including the Toronto area, Canada's most populous region, has been significantly influenced by anthropogenic activity (Sanderson et al. 2002; Statistics Canada 2007a). The ultimate impact of anthropogenic disturbances through land use change and population growth on both short term and long term ecosystem stability is a subject of much debate (Burden et al. 1986b; Ekdahl et al. 2007; Patterson et al. 2002; Trombulak and Frissell 2000; Watchorn et al. 2008; Whitelaw and Eagles 2007). Measuring the impact of these disturbances can be an important first step in long-term conservation planning, which may help ensure that at least parts of Canada remain as the "last of the wild", and that developed areas containing small islands of biogeographical diversity do not lose the biological diversity that remains (Sanderson et al. 2002).

Early in the $17^{\text {th }}$ century, European explorers arrived in the Great Lakes area to find already well-traveled trails leading from one body of water to another (Guillet 1933; Smith 1989). There is evidence that indigenous peoples inhabited Southern Ontario as early as A.D. 500, although it was not until some time between A.D. 1250 and A.D. 1420 that the Amerindian population of the area is estimated to have increased from $\sim 11,000$ to 29,000 individuals; a remarkable $1.07 \%$ per annum growth rate (Warrick 2000). Archaeological evidence of this 
population increase has been found in the form of the remains of many native villages dating from this time, located in upland locations away from traditional settlement areas near major rivers and lakes, and separated from each other by only 20 - $30 \mathrm{~km}$ (Warrick 2000). This increase in population resulted in changes to the landscape as land was cleared for agriculture and settlements, and as deer became less significant in local diets (Kapches 1981). An excellent example of indirect paleolimnological evidence of anthropogenic disturbances has been observed in cores from Crawford Lake, Ontario, which was adjacent to a known Amerindian (Iroquoian) village, using diatoms and pollen as biological proxies of this pre-European settlement land use change (Ekdahl et al. 2007; McAndrews and Turton 2007). High population growth (ca A.D. 1300), combined with finite availability of food (maize, fish, game), necessitated the relocation of many Iroquoian communities as well as the founding of new ones (Warrick 2000). Migrating Iroquoian communities generally did not locate on the Oak Ridges Moraine region with its poorer soils, as compared to the sand plains found surrounding Lake Ontario. However, archaeological studies have found the remains of at least one Iroquoian settlement on the Oak Ridges Moraine dating from this period of population increase and migration. The Wilcox Lake Iroquoian settlement, the Esox site (see Fig. 1), was a 1.2 ha village (early A.D. 1300's) located on the eastern end of the Oak Ridges Moraine, and was within $2 \mathrm{~km}$ of Haynes Lake (Austin 1994). The Iroquoians subsequently left the Oak Ridges Moraine area by the year 1550 A.D., as the physical and geographical constraints of food resources around Lake Ontario encouraged relocation to the 
north, particularly to the rich hunting grounds of the Lake Simcoe area (Warrick 2000; Stamp 1991).

Prior to A.D. 1825, Ontario was sparsely populated by Europeans, with only three communities having populations larger than 1000 , with Toronto, then known as York, being one of them. In 1795, the Governor of Upper Canada, John Graves Simcoe, planned to build the first highway in the area, which was to follow existing Amerindian trails. This highway became known as Yonge Street, and was to be built over 25 years to open a route between Lake Ontario and Lake Huron. The first portion of the road, which extended to Lake Simcoe, was completed in a year, and opened the area to settlement (Stamp 1991). To counter American expansionism from the south, the British military further encouraged settlement by clearing land for agriculture and for more roads in this area between A.D. 1825 - 1851. As a direct result, Ontario experienced rapid population growth as settlers poured in to establish farms on the fertile soils of the province (Gentilcore and Wood 1978). As Ontario's population swelled, roads were extended north to the Precambrian Shield between A.D. 1861 and 1891. By A.D. 1878 , the land immediately surrounding Haynes Lake had been cleared and was being farmed by several landowners including George Spraxton, Quetton St. George, Peter Baker and Christopher Smith (Canniff 1869; McGill University 2001). Evidence of significant anthropogenic disturbances to lake ecosystems as a result of this rapid $19^{\text {th }}$ century population growth and associated land clearance have been seen in many lakes in Ontario. For example, studies 
variously using diatoms, palynology and thecamoebians as biological proxies, in analysis of sediments from Grignac, Second, Swan and Crawford lakes have recorded significant impact to lake water quality as a result of disturbances to the landscape related to deforestation activities as the new settlements grew (Burden et al. 1986a; Patterson et al. 2002; Ekdahl et al. 2007; McAndrews and Turton 2007; Watchorn et al. 2008)

Previous research has indicated that it is possible to predict past water quality variables using a model based on the relationship between diatoms extracted from surface sediments and current water quality variables (Anderson 1995; Dixit et al. 2002; Enache and Prairie 2002; Hall and Smol 1996; Reavie and Smol 2001; Siver 1999; Watchorn et al. 2008). Similarly, many thecamoebian taxa have been shown to have preferences for particular environmental variables and, as such, analysis of changes in their populations provide important paleolimnological information (Kumar and Patterson 2000; Patterson and Kumar 2002; Patterson et al. 2002). The purpose of this study is to utilize both diatoms and thecamoebians to assess temporal changes in biological diversity in Haynes Lake, to determine whether both Medieval Iroquoian and $19^{\text {th }}$ century European settlement activities have had a long lasting impact on lake water quality and ecosystem stability, and to compare results of this study with results of a study of Swan Lake, Ontario (Watchorn et al. 2008), located $<1 \mathrm{~km}$ to the southwest. 


\section{Materials and methods}

\section{Study area}

Haynes Lake is a kettle lake located on the ORM (Fig. 1). The ORM area extends $160 \mathrm{~km}$ from the Trent River in the east to the Niagara Escarpment in the west. It is a $>100 \mathrm{~m}$-thick, till-glaciofluvial-glaciolacustrine sediment complex deposited as an inter-lobate moraine between about 13,000 and 15,000 years BP (Karrow 1989; Sharpe et al. 2004). This moraine acts as a recharge and discharge area for groundwater, supporting some 65 watercourses, and is a drinking water source for local communities (Gerber and Howard 2002; Whitelaw and Eagles 2007). The ORM also provides natural habitat for a large number of plant and animal species (Whitelaw and Eagles 2007). The ORM, with a population of approximately 100,000 residents, is situated within the Greater Toronto Area (GTA), which has a population of approximately 5.2 million people (2006 Census, Statistics Canada 2007b; Whitelaw and Eagles 2007). 


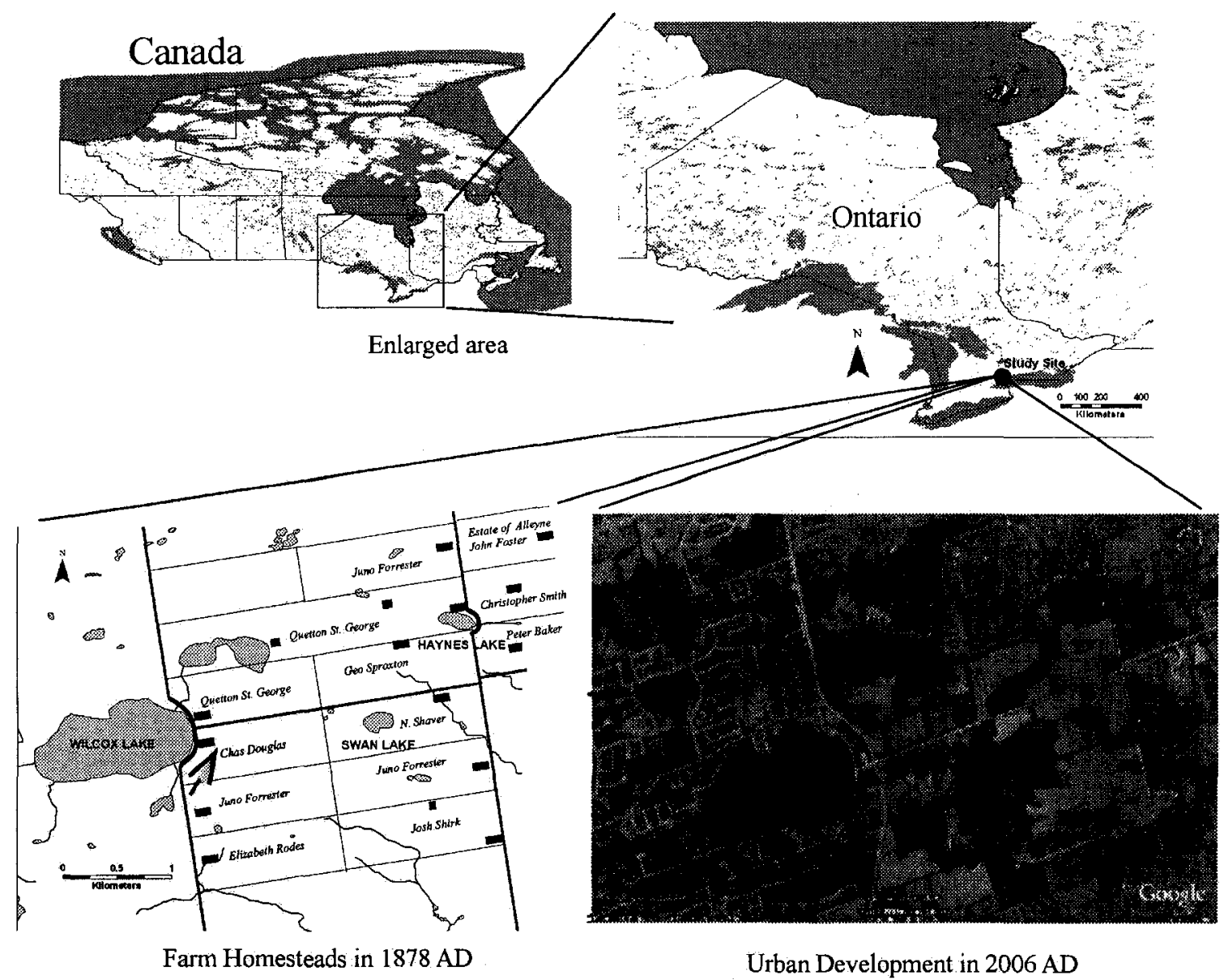

Fig. 1. Site Map of Haynes Lake, Ontario, Canada.

Note the location of Swan Lake Ontario, $<1 \mathrm{~km}$ to the west, and the Iroquoian settlement, Esox Site, $300 \mathrm{~m}$ to the east of Wilcox Lake, indicated with an arrow (DMTI Spatial Inc. 2003; Google Earth ${ }^{T M}$ Mapping Service 2007; Natural Resources Canada 2002; Stamp 1991; Statistics Canada 2001). 
Haynes Lake $\left(43^{\circ} 57^{\prime} 57^{\prime \prime} \mathrm{N} ; 79^{\circ} 24^{\prime} 42^{\prime \prime} \mathrm{W}\right)$ is one of many kettle depressions in the moraine (Fig. 1). It is a small lake, at $0.4 \mathrm{~km}$ long by $0.13 \mathrm{~km}$ wide, with a maximum depth of $16 \mathrm{~m}$, and is at about $255 \mathrm{~m}$ above sea level. The surrounding land is level with the lake to the east and the south, while land on the north side lies about $20 \mathrm{~m}$ above water level, and land from mid-way between Wilcox Lake and Haynes Lake on the west side slopes gently towards the lake. There is a road (Regional Road 12) located immediately adjacent to the lake and well within the floodplain of Haynes Lake. When lake levels are high, particularly in the spring, a portion of the highway is often submerged. One house is situated on the north side of Haynes Lake, and there is a golf course just to the north of the house. The rest of the lake is surrounded by mixed deciduous and coniferous forest, with roads, farmland, and residential areas beyond. There were Common Cattails (Typha latifolia L.), Eurasian Water Milfoil (Myriophyllum spicatum L.), and zebra mussels (Dreissena polymorpha Pallas) observed in the water. Populations of Canada Geese (Branta canadensis L.) were also observed on the lake during spring and fall.

\section{Sediment Core Details and Chronology}

Sediment cores were extracted from the bottom of Haynes Lake $\left(43^{\circ} 57^{\prime} 55^{\prime \prime} \mathrm{N}\right.$; $79^{\circ} 24^{\prime} 48^{\prime \prime}$ ) ) using a Livingstone corer (Deevey 1965) on August 20, 2005 at $16 \mathrm{~m}$ water depth. One sediment core, Haynes HYC1, was collected in three sections measuring $94.5 \mathrm{~cm}, 96.0 \mathrm{~cm}$, and $81.0 \mathrm{~cm}$ respectively, for a total of $269.5 \mathrm{~cm}$. Two other cores, Haynes HYC2 and Haynes HYC3, were collected 
from the same location to provide material for dating, and for study utilizing other proxies.

The three sections of the core used in this study (HYC1-1, HYC1-2, and HYC1-3) were $\mathrm{x}$-rayed to identify distinct layers with a Kevex x-ray machine at $40 \mathrm{kV}$, and 27 - $44 \mathrm{~mA}$, with exposure times ranging from 90 - 180 seconds. The images were captured on erasable phosphor plates and digitally recovered using an OREX scanner with VideoRen® software (version 1.0).

One sediment sample $(1000 \mathrm{mg})$ from Haynes Core HYC1-3-22-23 $(211 \mathrm{~cm}$ core depth) was sent to IsoTrace Radiocarbon Laboratory (University of Toronto) for bulk dating analysis. Two separate analyses (normal precision) were conducted, correcting for natural and sputtering isotope fractionation. Results were measured using the ${ }^{13} \mathrm{C} /{ }^{12} \mathrm{C}$ ratio, with sample age quoted as an uncalibrated conventional radiocarbon date in years before present, using the Libby ${ }^{14} \mathrm{C}$ mean life of 8033 years. The error represents the $68.3 \%$ confidence limit.

Thirteen samples from Haynes Core $\mathrm{HYC}$, taken from $0-36.5 \mathrm{~cm}$ core depth, were sent to the Science Museum of Minnesota for ${ }^{210} \mathrm{~Pb}$ dating analysis. Dates and sedimentation rates were determined according to the c.r.s. (constant rate of supply) model (Appleby et al. 1986; Appleby and Oldfield 1978) with confidence intervals calculated by first-order error analysis of counting uncertainty (Binford 1990). 


\section{Diatom Preparation and Enumeration}

Diatoms were used as a biological proxy in this study to infer changes in water chemistry through time. Diatoms deposited in Haynes Lake sediment were analyzed by extracting them from twenty $1 \mathrm{~cm}$ thick subsamples from Core $\mathrm{HYC1}$, corresponding to a range of sample depths from $1 \mathrm{~cm}$ to $188.5 \mathrm{~cm}$.

Approximately $1 \mathrm{cc}$ of wet sediment was extracted, weighed and freeze-dried from each of the subsamples. The subsamples were then prepared for diatom analysis by weighing out $0.032 \mathrm{~g}-0.058 \mathrm{~g}$ of dry sediment. A $10 \mathrm{ml}$ solution of 50:50 nitric/sulfuric acid was added to each sediment sample and heated for approximately 20 minutes to remove organic material. The acid mixture was then diluted with distilled water and sonicated to disaggregate the diatom frustules into single valves. Subsequently, the acid was removed from the samples through centrifugation and a series of at least five distilled water dilutions. Finally, washed samples were stored for further processing in $45 \mathrm{ml}$ of distilled water.

Aliquots of $0.5 \mathrm{ml}$ from the washed diatom solution were pipetted onto $18 \mathrm{~mm} \mathrm{x}$ $18 \mathrm{~mm}$ coverglasses and allowed to air-dry. The coverglasses were fixed onto microscope slides with Naphrax ${ }^{\circledR}$ mountant. Two microscope slides were prepared for each sample; one for analysis with a Leica $D \mathrm{R}^{\circledR}$ light microscope with phase contrast optics, and the others as reserve slides for cross-reference and verification. Prior to diatom counting, two scanning electron microscope stubs was prepared from two samples to identify small diatoms using an FEI XL 
Environmental Scanning Electron Microscope (ESEM). All of the quantified prepared microscope slides, the remaining subsample material, associated notes and photomicrographs are archived in the National Collection at the Canadian Museum of Nature, in Ottawa.

At least 600 diatoms were counted at $1600 \mathrm{X}$ magnification from each slide using a transect counting protocol (Pappas and Stoermer 1996; Watchorn et al. 2008). The number of valves per gram dry weight (total valves $\mathrm{g}^{-1} \mathrm{dwt}$ ) and percent abundance were subsequently calculated for each taxon. Flux rates were subsequently determined using ${ }^{210} \mathrm{~Pb}$ and sediment accumulation measures. The diatoms were identified using standard taxonomic references (e.g. Camburn and Charles 2000; Fallu et al. 2000; Germain 1981; Jahn et al. 2001; Krammer 1997a, b, 2000, 2002, 2003; Krammer and Lange-Bertalot 1986, 1988, 1991a, 1991b; Lange-Bertalot 2001; Lange-Bertalot and Krammer 1989; Lange-Bertalot et al. 1996; Meltzeltin et al. 2005; Patrick and Reimer 1966,1975; Reavie and Smol 1998; Reichardt 1999; Round et al. 1990; Siver et al. 2005; Van de Vijver et al. 2004; Werum and Lange-Bertalot 2004). 


\section{Thecamoebian Preparation and Enumeration}

Twenty samples for thecamoebian analysis were obtained from the same Haynes Lake subsamples as were used for diatom analysis. Each $1 \mathrm{cc}$ sample prepared for thecamoebian study was screened with a $43 \mu \mathrm{m}$ sieve to retain thecamoebians and to remove silts and clays. Wet aliquots were then examined under an Olympus binocular stereomicroscope at 40 - 80X magnification. Taxa identification followed Kumar and Dalby (1998). Each entire $1 \mathrm{cc}$ sample was counted for thecamoebians. Relative fractional abundance was subsequently calculated for each taxonomic unit.

\section{Data Analysis}

A diatom-water quality transfer function for Haynes Lake was developed following the format of Watchorn et al. (2008) using the program C2 version 1.5 (Juggins 2005). Fifty lakes from the Reavie and Smol (2001) calibration set that had complete data for spring growing conditions, including $\mathrm{pH}$, and total phosphorus (TP), were used as the calibration model to infer past water chemistry values in Haynes Lake. Lakes used in the calibration set are located $<275 \mathrm{~km}$ to the east of Haynes Lake and are situated on bedrock formations of limestone (Trenton and Beekmantown formations), granitic (Precambrian Shield) rock, or a mixture of the two (Chapman and Putnam 1966). Reconstruction of past water chemistry values for Haynes Lake were generated using 85 taxa from the fossil assemblage that were also found in the Reavie and Smol (2001) calibration set. The species relative abundance data was square-root transformed for weighted 
averaging (WA) analyses to reduce the effect of dominant taxa, as previously described in Reavie and Smol (2001).

MVSP version 3.13p software was used for cluster analysis to determine . associations between core depth and diatom and thecamoebian species in Haynes Lake. The diatom and thecamboebian species percent abundance data was first square-root transformed to normalize the data, and then the Squared Euclidean (minimum variance) method of Cluster Analysis was used to determine the relationships. 


\section{Results}

\section{Sediment Core Details and Chronology}

$\mathrm{X}$-ray analysis indicated distinctive laminations and changes in sedimentology in

Haynes Lake sediments through time (Fig. 2A, 2B, 2C, 2D, 2E). The top $30 \mathrm{~cm}$ of the core was composed of very dense, finely layered clay. In order to capture a clear x-ray image of this very dense section, the top $30 \mathrm{~cm}$ of the core was subjected to the longest exposure times and highest amperages of any section of the core. There was a distinctive change in sedimentology at $30 \mathrm{~cm}$ core depth, with layers higher in organic material (appearing as dark areas on the x-ray images) alternating with layers higher in clay content below this core depth. A thick, distinctive region of high organic content was observed at approximately 70 $\mathrm{cm}$, with frequent changes in bedding orientation beginning at this horizon and continuing to about $140 \mathrm{~cm}$ depth, where bedding orientation returned to a horizontal orientation, as was observed in the top $70 \mathrm{~cm}$ of sediments.

Radiocarbon and ${ }^{210} \mathrm{~Pb}$ dating methods indicate that the sediments recovered in the examined core span ca A.D. $656(211.5 \mathrm{~cm})$ to ca A.D. $2003(1 \mathrm{~cm})$, with a margin of error ranging from 2 to 47 years. Interpolation of these data using a second order polynomial curve $\left(R^{2}=0.998\right)$ provided estimates for the ages of intervening sediment samples (Fig. 3). 


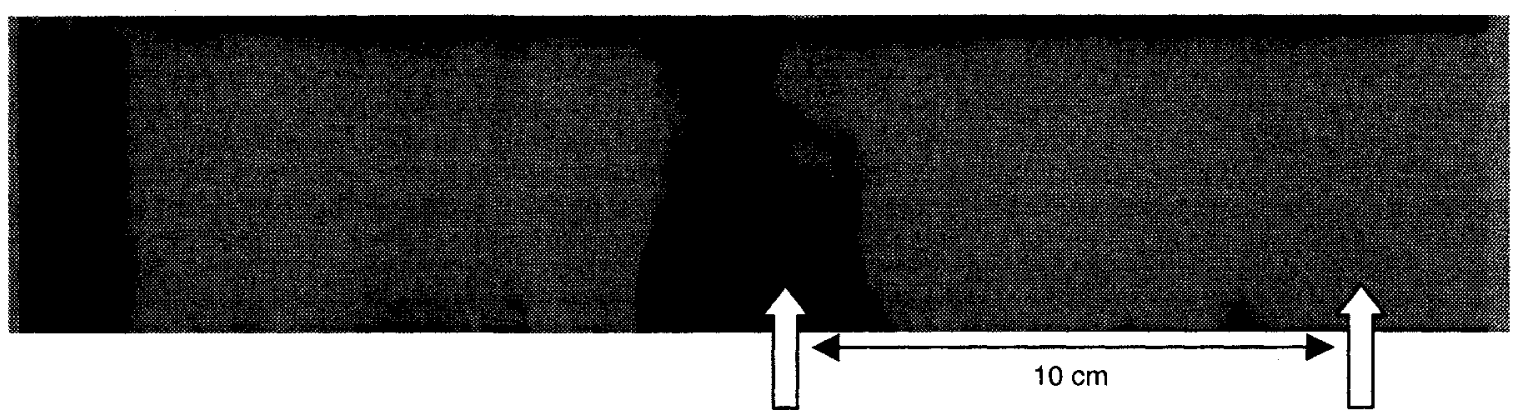

Fig. 2A. Haynes Lake Core x-ray: $\sim 0-20 \mathrm{~cm}$ depth from core HYC1-1. The top direction is to the left.

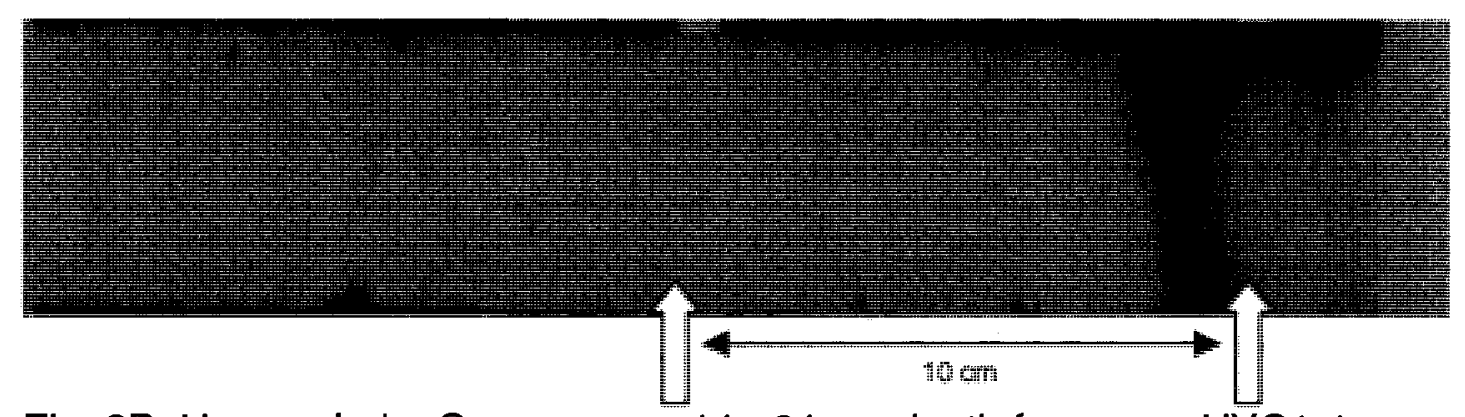

Fig. 2B. Haynes Lake Core x-ray: $\sim 14-34 \mathrm{~cm}$ depth from core HYC1-1. The top direction is to the left.

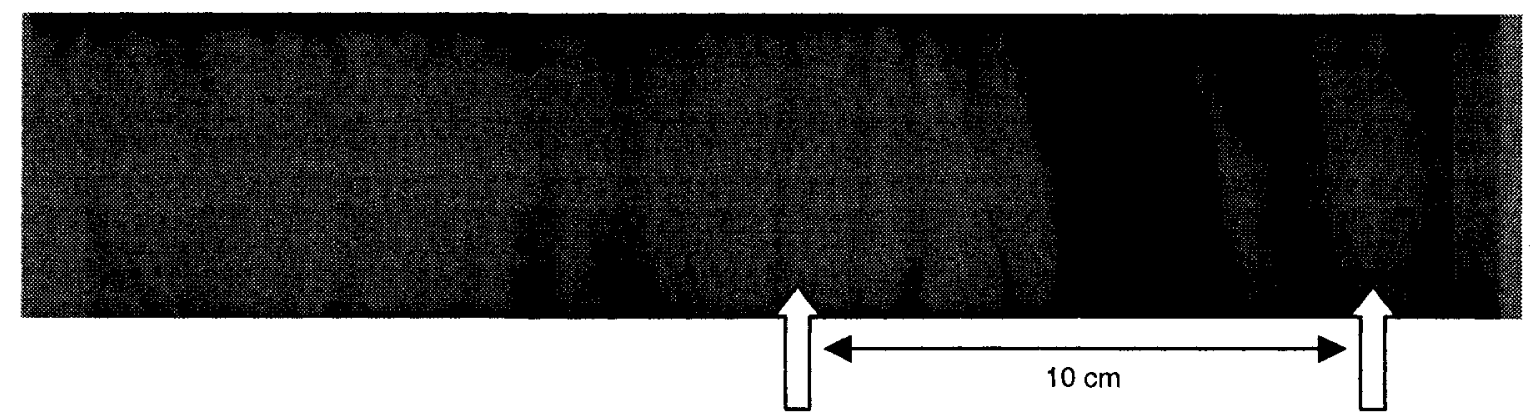

Fig. 2C. Haynes Lake Core X-ray: $\sim 54-74 \mathrm{~cm}$ depth from Core HYC1-1. The top direction is to the left. 


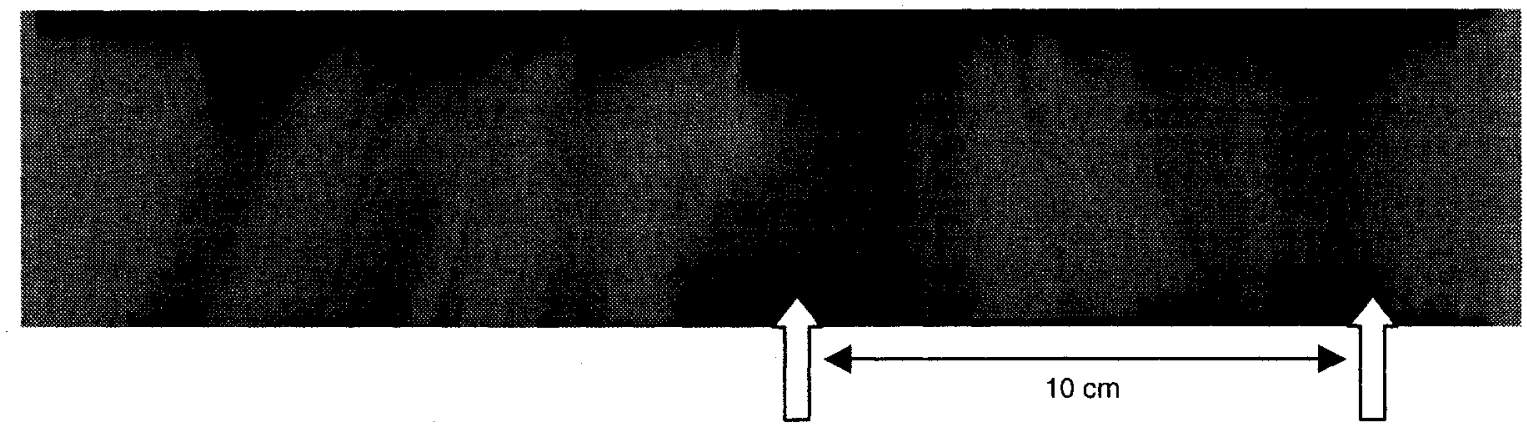

Fig. 2D. Haynes Lake Core x-ray: $114-134 \mathrm{~cm}$ depth from core HYC1-2. The top direction is to the left.

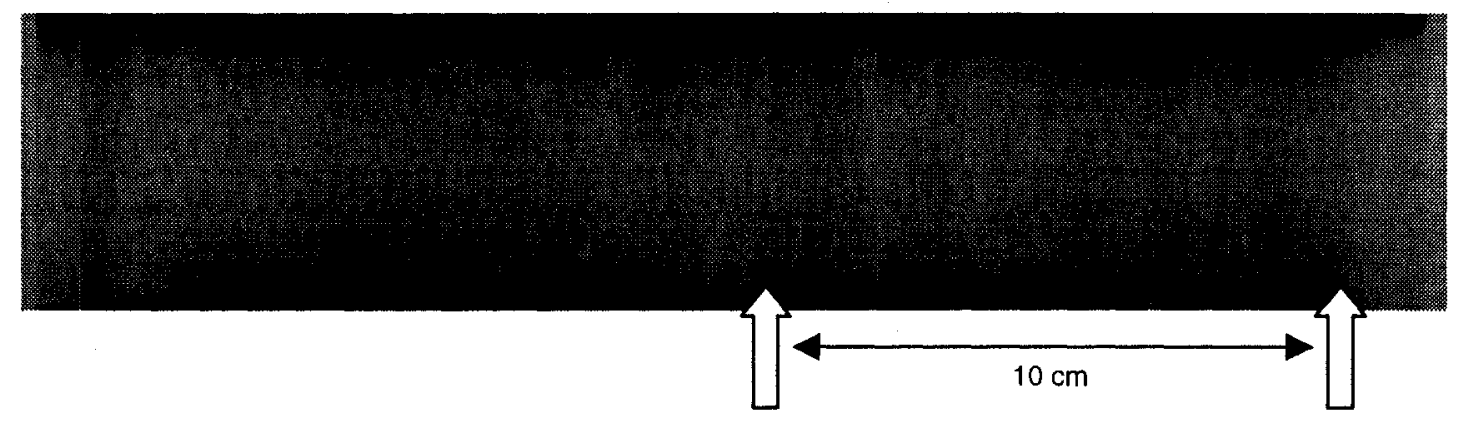

Fig. 2E. Haynes Lake Core x-ray: $134-154 \mathrm{~cm}$ depth from core HYC1-2. The top direction is to the left. 


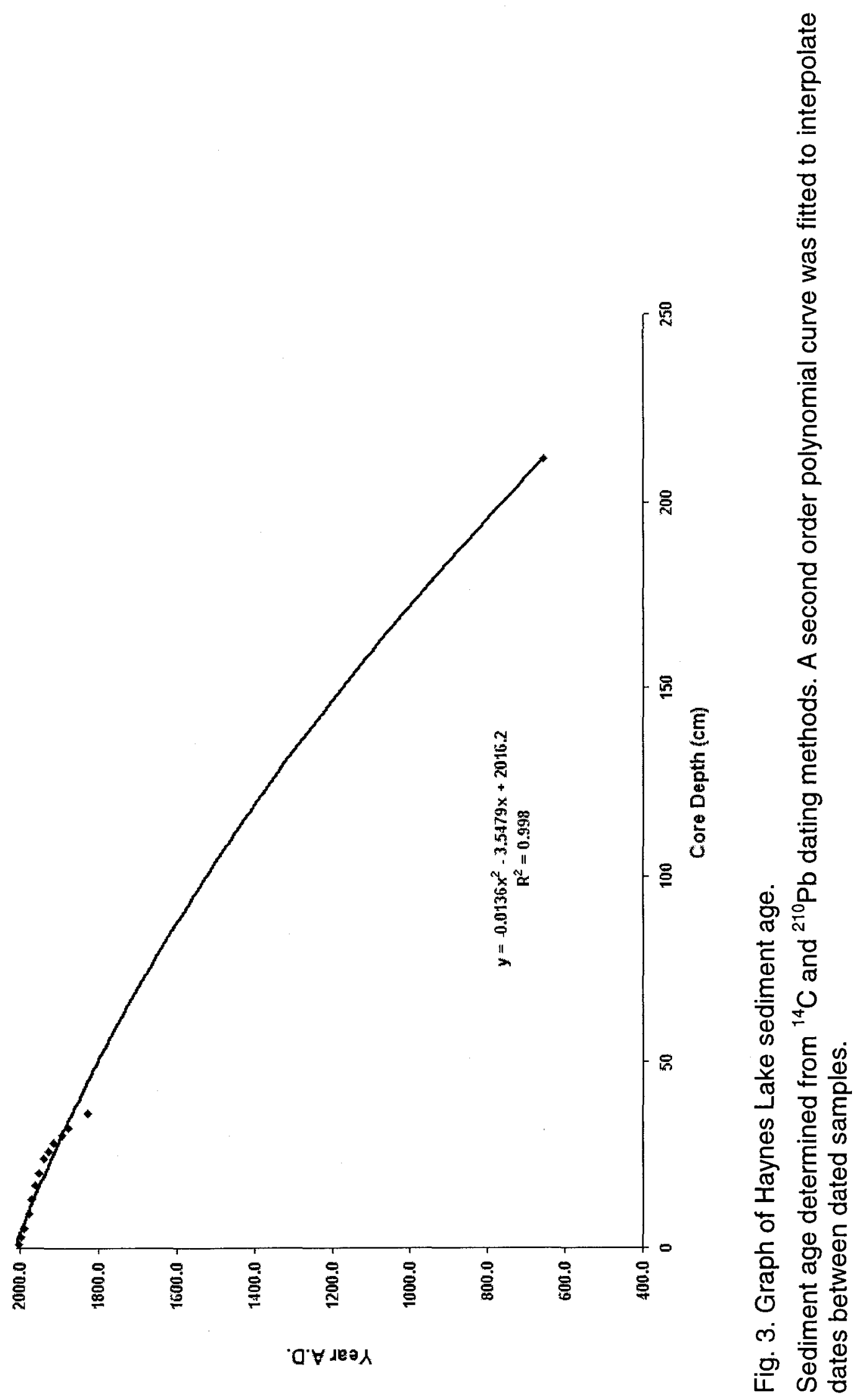




\section{Fossil Diatom Assemblages}

Ninety-six different taxa were identified from twenty-five genera in the Haynes Lake sediment core. Of these taxa, sixteen were present at $>5 \%$ abundance in at least one sample and were deemed present in statistically significant enough amounts for subsequent analysis (Patterson and Fishbein, 1989). Species assemblages changed as sediment depth decreased, with particularly distinct changes noted through the top $30 \mathrm{~cm}$ and below $130 \mathrm{~cm}$ in the core (Fig. 4).

At the base of the core $(188.5-140 \mathrm{~cm})$, the dominant species were Cyclotella comensis Grunow 1882, Cyclotella michiganiana Skvortzow 1937, and Cyclotella pseudostelligera Hustedt 1939 (Fig. 4). Other prominent species included Encyonema silesiacum Bleisch 1861, Nitzschia amphibia Grunow 1862, Fragilaria capucina Desmazieres 1825 sensu lato and Navicula cryptotenella Krammer \& Lange-Bertalot 1985 . The diatom community changed dramatically at $130 \mathrm{~cm}$ core depth (ca. A.D. 1325), with Fragilaria nanana Lange-Bertalot 1993 temporarily increasing in abundance along with Navicula cryptotenella, Encyonema silesiacum, Achnanthidium minutissimum (Kützing) Czarnecki 1994, and Fragilaria capucina sensu lato. From 130 to $\sim 30 \mathrm{~cm}$ (ca. A.D. 1325 - ca. A.D. 1890), there was a general decline in Encyonema silesiacum and Nitzschia amphibia, with successional increases in C. pseudostelligera $(120 \mathrm{~cm}), C$. comensis $(100 \mathrm{~cm})$, Cyclotella bodanica Grunow 1878 sensu lato $(75 \mathrm{~cm})$ and $C$. michiganiana $(60 \mathrm{~cm})$. From $30-2 \mathrm{~cm}$, a clay layer was present with a successional shift in the diatom flora from Fragilaria capucina, Navicula cryptotenella and Nitzschia amphibia to C. pseudostelligera $(30 \mathrm{~cm})$, Fragilaria 
nanana $(15 \mathrm{~cm})$, Cyclotella michiganiana $(11 \mathrm{~cm})$, and Achnanthidium

minutissimum $(5 \mathrm{~cm})$. At the top of the core $(<5 \mathrm{~cm})$ Asterionella formosa Hassall 1850 and Stephanodiscus medius Håkansson, 1986, became more prominent in conjunction with a decline in the relative abundance of $A$. minutissimum. Asterionella formosa was absent down-core, but at the top of the core represented the third most dominant species, at $14.5 \%$ abundance. Stephanodiscus medius was also absent below $25 \mathrm{~cm}$, but in the top $5 \mathrm{~cm}$ composed $12.9 \%$ of the assemblage.

\section{Diatom-inferred pH (DI-pH) and Total Phosporus (DI-TP)}

There were distinct changes in spring diatom-inferred pH (Fig. 4) recognized throughout the Haynes Lake sediment core. The inferred pH ranged from 7.9 8.3 in the deepest part of the core $(188.5 \mathrm{~cm}-110 \mathrm{~cm})$. The highest DI-pH (8.7) occurred at $100 \mathrm{~cm}$ core depth, and fluctuated between 7.9 and 8.5 from $80 \mathrm{~cm}$ core depth to $40 \mathrm{~cm}$. At $30 \mathrm{~cm}$ core depth, the DI-pH dropped to 7.7 and remained near these levels to $1 \mathrm{~cm}$ depth, where it rose to 8.0. The lowest DI-pH was documented at $15 \mathrm{~cm}$ depth (7.6). Direct measurements of $\mathrm{pH}$ from Haynes Lake water samples provided values of 7.97 (August 2005), and 8.13 (September 2007), closely correlating with the diatom inferred $\mathrm{pH}$ value obtained in the top $\mathrm{cm}$ of the core.

Diatom-inferred total phosphorus (DI-TP) was subject to large error, and changes through time were not significant (Fig. 4). Interestingly, however, DI-TP at $1 \mathrm{~cm}$ core depth was determined to be $0.011 \mathrm{mg} \mathrm{L}^{-1}$, while instrument measured TP 
was nearly identical, ranging from $0.011-0.012 \mathrm{mg} \mathrm{L}^{-1}$. The highest DI-TP values corresponded to $45 \mathrm{~cm}$ core depth at $0.013 \mathrm{mg} \mathrm{L}^{-1}$, while the lowest values were observed at $110-120 \mathrm{~cm}$ and $30 \mathrm{~cm}$ core depth $\left(\sim 0.008 \mathrm{mg} \mathrm{L}^{-1}\right)$. 


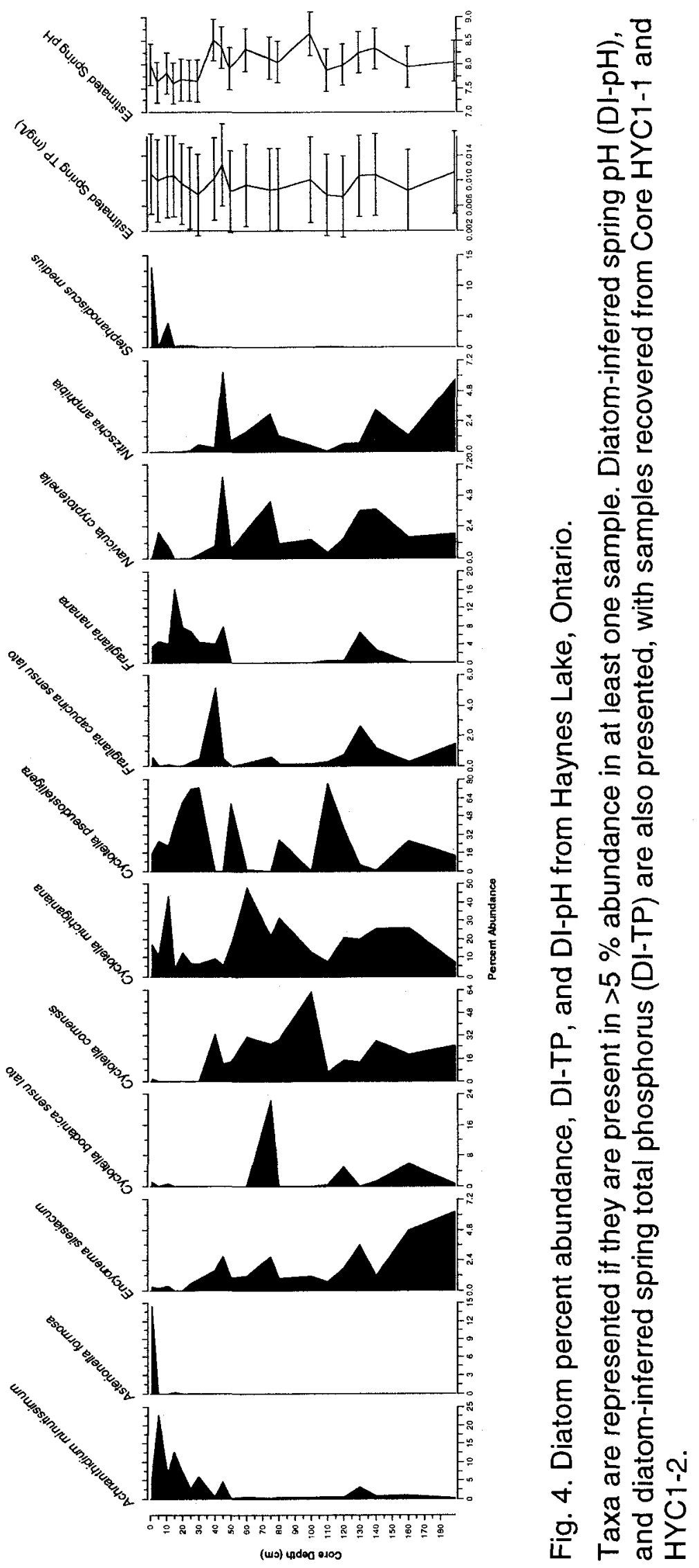




\section{Fossil Thecamoebian Assemblages}

Sixteen taxa were identified in the Haynes Lake core. Of these taxa, seven were present in at least $5 \%$ abundance in at least one sample (Fig. 5). In the lowermost core section (188.5 - $140 \mathrm{~cm}$ ), the dominant species were Arcella vulgaris (Ehrenberg, 1830) and Centropyxis aculeata "discoides" (Ehrenberg, 1832). At $130 \mathrm{~cm}$ core depth, $A$. vulgaris remained the dominant thecamoebian. However a change in species composition was noted at this horizon, with Cucurbitella tricuspis (Carter, 1856) becoming the second most dominant species at $18 \%$ abundance. Arcella vulgaris remained the dominant species until $30 \mathrm{~cm}$ core depth, when it dropped to $2 \%$ abundance, and rose in abundance to $7 \%$ abundance at $1 \mathrm{~cm}$ core depth. At $60 \mathrm{~cm}$ core depth, the assemblage was almost entirely comprised of $C$. tricuspis and $A$. vulgaris (ca. 1750 A.D.).

Above this core depth, Centropyxis aculeata "aculeata" (Ehrenberg, 1832) increased in abundance (at $50 \mathrm{~cm}$ ) generally making up $>20 \%$ of the assemblage to the top of the core. $C$. triscuspis temporarily decreased in abundance above $50 \mathrm{~cm}$, increasing to at $\sim 40 \%$ at $30 \mathrm{~cm}$. Cucurbitella tricuspis abundance remained at $>28 \%$ above this horizon, becoming the dominant species at $1 \mathrm{~cm}$ depth (62\% abundance). 


\section{Cluster Analysis}

Cluster analysis of the diatom data resulted in recognition of three main clusters, with the most distinctive cluster comprising the samples from the top $30 \mathrm{~cm}$ of the core (Fig. 6). This cluster was separated from the next closest cluster by about

2.5 times the squared Euclidean distance, while a distance of approximately 5.5 times the squared Euclidean distance separated the third cluster. Cluster analysis of the thecamoebian data (Fig. 7) also resulted in recognition of three main clusters, with the most obvious cluster also comprising samples from the top $30 \mathrm{~cm}$. 


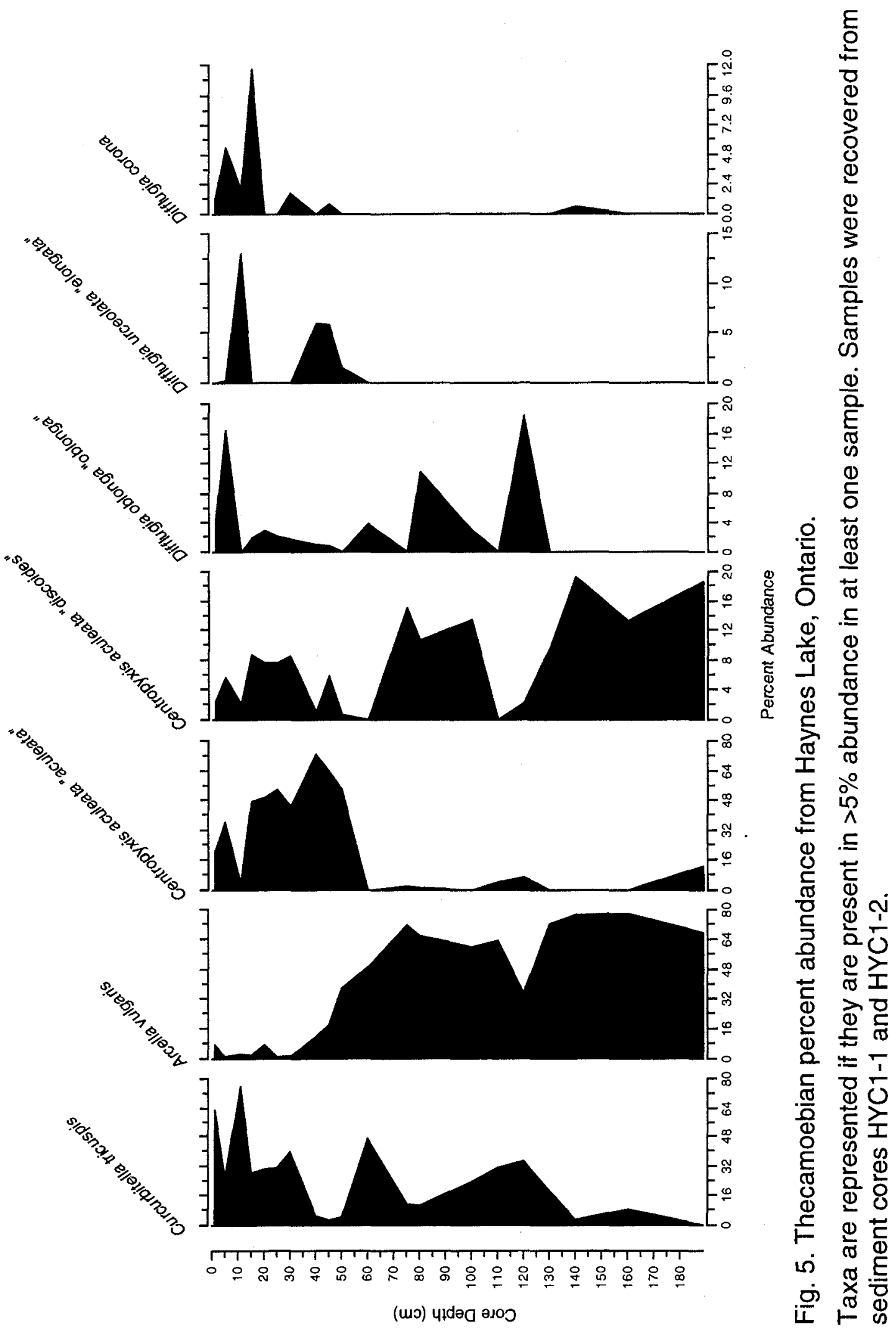




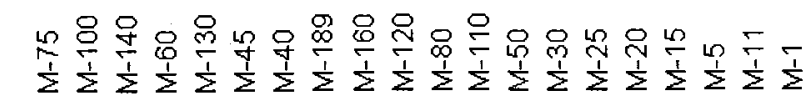

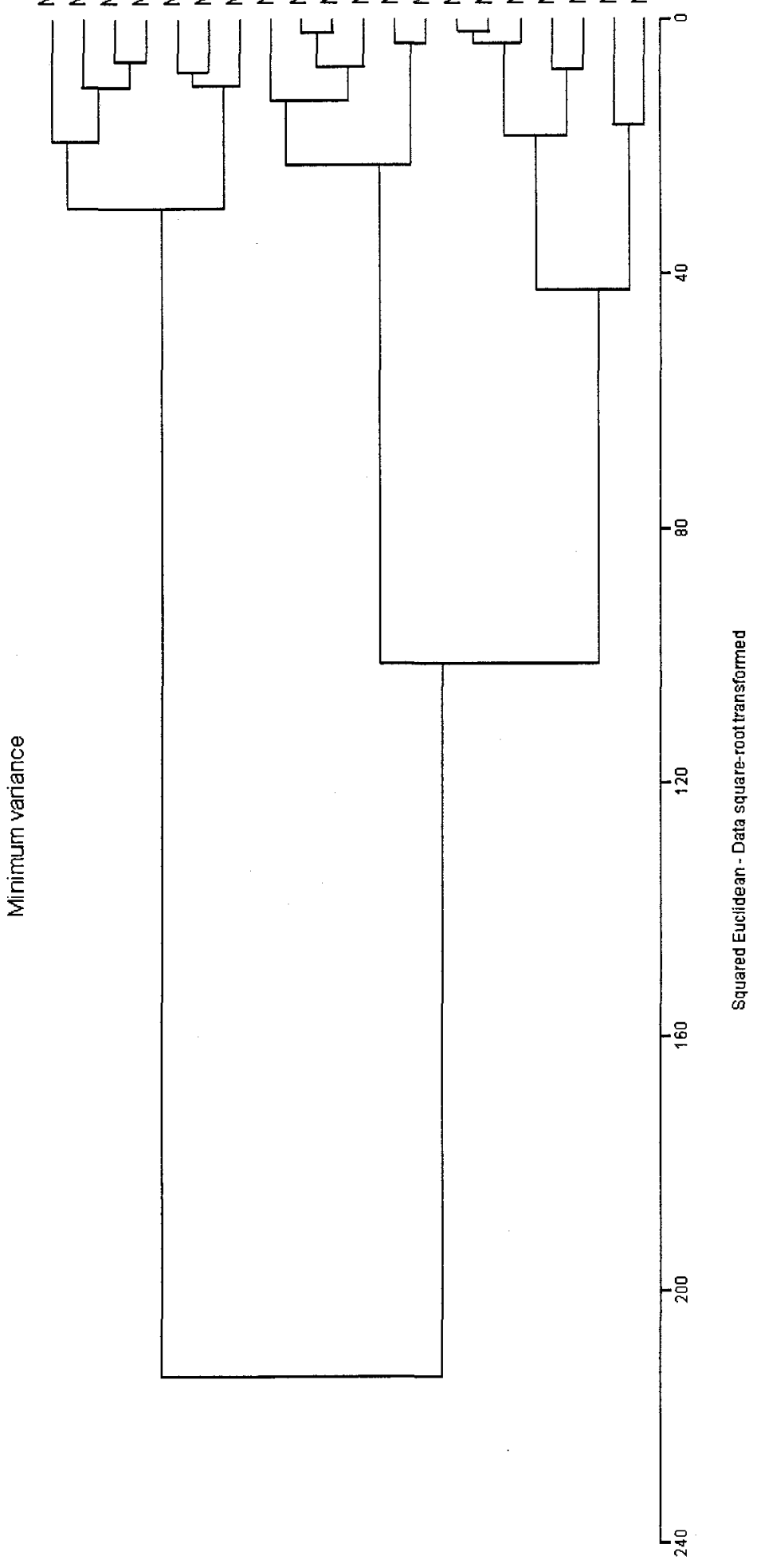

$\stackrel{0}{\stackrel{5}{*}}$

劳

立

$\stackrel{\square}{ \pm}$

ن

ब

寻 主

응 응 믄

交 $\frac{1}{1}$

采

은 主

过

동

\% 3

จ

त

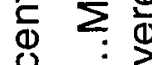

ฮั

造

这

क응ㅎㅇ

등 응

.0.

\%

ॅ․

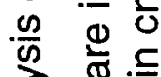

ते

สิ N

๘

ว क

๑ 응 응

宅 


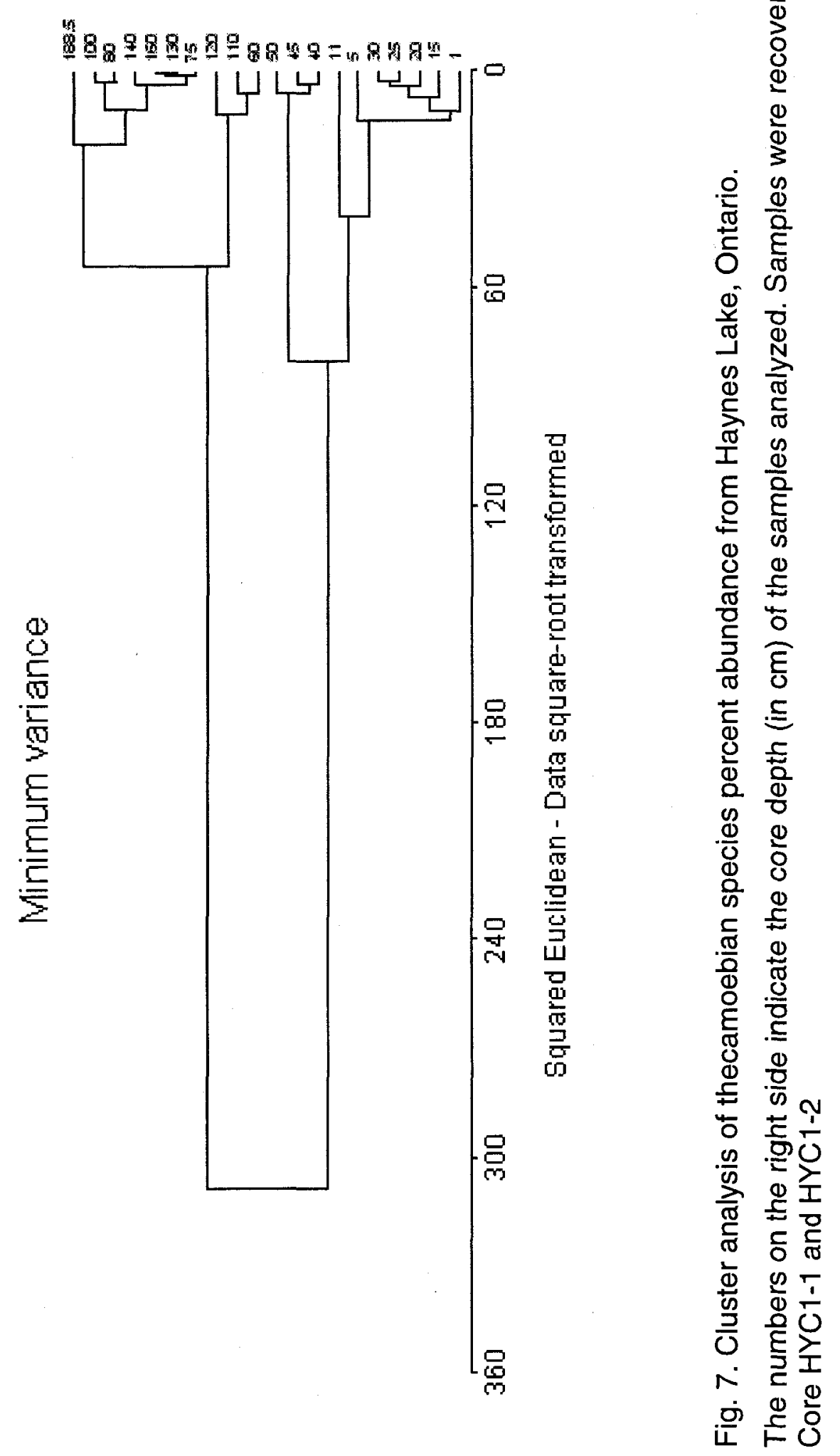




\section{Discussion}

Interpretation of the microfossil and sedimentary record from a core collected from Haynes Lake, ORM, Ontario, spanning the period from ca. A.D. 656 to the present indicates that there were three periods of significant disturbance to the lake ecosystem through this interval. These disturbances, all associated with major changes in sedimentology, diatom flora assemblages and thecamoebian fauna assemblages, can all be linked to human-induced alteration of the surrounding landscape.

Frequent changes in bedding orientation of the sediments commencing above $140 \mathrm{~cm}$ core depth, as observed through x-ray analysis (Figs. 2D, 2E), provide the earliest record that the lake was altered. A major change in the diatom flora at $130 \mathrm{~cm}$ core depth (ca. A.D. 1325 A.D.) is also indicative of a significant change to the lake ecosystem. For example, Fragilaria capucina sensu lato, Fragilaria nanana and Achnanthidium minutissimum, an epiphytic species that can tolerate a broad range of disturbance conditions (Beaver 1981; Potapova and Hamilton 2008), were found to increase in abundance at this horizon. Cyclotella bodanica also decreased in abundance in comparison to assemblages found in older sediments in the core. These changes in the core record correlate well with increases in the rate of Iroquoian population growth, which has been linked to increased rates of land clearance for maize agriculture in Southern Ontario (Warrick 2000), suggesting a link between anthropogenic activities and changes in the lake ecosystem. The limnological changes observed in Haynes 
Lake are similar to lake ecosystem modifications observed at Crawford Lake $\sim 70 \mathrm{~km}$ to the west, on the Niagara Escarpment, which has also been linked to Iroquoian agricultural land clearance. As observed at Haynes Lake, $A$. minutissimum increased in abundance in sediments deposited in Crawford Lake following Iroquoian settlement of the area (Ekdahl et al. 2007). Similarly, $C$. bodanica decreased in abundance in Crawford Lake through this interval, as also observed at Haynes Lake (Ekdahl et al. 2007).

Significant changes in the thecamoebian fauna also occurred at the $130 \mathrm{~cm}$ horizon in Haynes Lake, when Cucurbitella tricuspis, a species that has been correlated with eutrophic conditions (Patterson et al. 2002), dramatically increased in abundance. These results also correlate well with the results of a paleolimnological study at nearby Swan Lake, where an ecologically destabilized assemblage of thecamoebians indicated there was a period of deforestation spanning the interval from ca. A.D. 1350 - A.D. 1700 (Patterson et al. 2002). These observations provide corroborative evidence that there was a significant widespread environmental impact on lake ecosystems caused by the higher rate of land clearance for maize agriculture, that was required to support the expanding Iroquoian populations, and increased number of native villages in the $14^{\text {th }}$ and $15^{\text {th }}$ centuries. Indeed, the close proximity $(<2 \mathrm{~km})$ of the Wilcox Lake archaeological site (Esox Site; Fig. 1) to Haynes Lake presents even stronger evidence for direct links between land clearance for maize agriculture there, and 
its impact on local water quality and lake biodiversity (Austin 1994; Stamp 1991; Warrick, 2000).

Analysis of the $75-60 \mathrm{~cm}$ interval of the Haynes Lake core provides evidence of a second period of disturbance as indicated by changes in sedimentology, and diatom and thecamoebian assemblages. This interval was deposited ca. A.D. $1670-1750$ and correlates with the first contact between the Iroquoians and Europeans who arrived from France and began initial settlement of the area by building forts in Toronto and Niagara, and then later by clearing and burning the virgin forest to make way for housing and agricultural activities (Guillet 1946; Smith 1989; Mitchell 1952). X-rayed images of the core reveal that changing sedimentation patterns that characterized the $140-70 \mathrm{~cm}$ interval in the core differed from the horizontal, laminar style of sedimentation above $70 \mathrm{~cm}$ (Fig. 2C). A major change in the diatom assemblage through the $75-60 \mathrm{~cm}$ interval provides biological evidence of the changing land-use patterns, with C. michiganiana, a meso-eutrophic planktonic species (Ekdahl et al. 2007), becoming the dominant species by $60 \mathrm{~cm}$ core depth. Cyclotella pseudostelligera decreased in importance at $75 \mathrm{~cm}$ depth, while Cyclotella bodanica, also a meso-eutrophic species (Reavie et al. 1995), appeared in the assemblage in significant numbers for the first time at the $75 \mathrm{~cm}$ horizon. Above the $60 \mathrm{~cm}$ core horizon (ca. 1750 A.D.), the thecamoebian assemblage in the Haynes Lake sediment core are almost entirely composed of the alkalphilic species $C$. tricuspis and $A$. vulgaris, a stressed environment indicator (Patterson 
and Kumar 2001), providing further evidence of significant land-use change in the area around the lake.

The top $30 \mathrm{~cm}$ of the Haynes Lake sediment core, which encompasses the interval from ca. AD 1890 to the present day, correlates with the flood of European settlers that came to the area at that time (Canniff 1869). More precisely, clearance of the land immediately to the west of Haynes Lake probably began soon after parcels were granted to two settlers; William Bond, (Concession II, Lot 7, Whitchurch Township) in 1798 (Archives of Ontario 1979), who developed his land into a nursery and fruit farm (Guillet 1946), and William Wilcocks (Concession II, Lot 6, Whitchurch Township), in 1802. This portion of the core, with its high clay content, would have been deposited as a result of anthropogenic resuspended sediment, which was introduced as a consequence of erosion due to deforestation for housing and agriculture, and with the construction of Regional Road 12 along the edge of the lake (Gentilcore and Wood 1978; Langman 1971).

At $30 \mathrm{~cm}$ core depth (ca. A.D. 1890), changes in diatom species assemblage were also noted when Cyclotella comensis, Navicula cryptotenella, and Nitzschia amphibia all decreased in abundance. Also, C. comensis, a species associated with oligotrophic conditions (Sorvari and Korhola 1998), and N. amphibia did not appear in the assemblage above this core depth. The $\mathrm{DI}-\mathrm{pH}$ ratio declined to 7.7 at $30 \mathrm{~cm}$ depth, and further declined to 7.6 at $15 \mathrm{~cm}$ depth, the lowest $\mathrm{DI}-\mathrm{pH}$ ratio 
of the samples that were analyzed, indicative of the clastic deposition of clay as shown by the x-ray results. Similar changes in diatom floral makeup have been observed with road construction and resultant clay input in other lakes (e.g.Third Sister Lake, Michigan; Hammer and Stoermer 1997).

The changes in the diatom species assemblage in Haynes Lake in the postEuropean settlement phase were not as significant as those noted to have occurred in Swan Lake during this same time period. At Swan Lake, the highest DI-TP levels were inferred to have occurred during the European settlement period, indicating a high degree of erosion due to deforestation (Watchorn et al., 2008), whereas changes in DI-TP across the European settlement horizon in Haynes Lake were much more equivocal, with large error estimates. The DI-pH ratio (Fig. 4), however, does provide a good way to explain temporal changes in the diatom species assemblages in Haynes Lake.

Thecamoebian data from the top $30 \mathrm{~cm}$ of the Haynes Lake sediment core agree with results observed in the diatom flora obtained from the same sample depths. Cluster analysis of both diatom and thecamoebian data indicate that this portion of the core is distinctly different from the rest of the core (Figs. 6, 7). Although $C$. tricuspis continued as a dominant taxa above $30 \mathrm{~cm}$, significant changes in thecamoebian assemblage are indicated by the emergence of $C$. aculeata "aculeata", another stressed environment indicator, as a dominant taxa through the top $30 \mathrm{~cm}$, and by a large reduction in the proportion of $A$. vulgaris through 
this interval. Changes in assemblage were also noted in nearby Swan Lake from the European settlement period, with $C$. aculeata and $A$. vulgaris present in higher proportions than that observed in older sediments (Patterson et al. 2002). This provides further evidence of the disturbed ecosystems that exist in many modern lakes as a direct result of anthropogenic disturbances to the landscape, such as erosion due to deforestation and road building, that occurred during the European settlement period (Hall and Smol 1996; Hammer and Stoermer 1997; Patterson et al. 2002; Reavie and Smol 2001; Watchorn et al. 2008).

\section{Conclusions}

This multiproxy dataset indicates varying degrees of disturbance occurred in the Haynes Lake ecosystem through the period from ca. A.D. 656 to ca. A.D. 2003. Both Iroquoian inhabitation and European settlement had an impact on lake water quality and sedimentation in Haynes Lake, with the most severe disturbance indicated by the diatom flora, the thecamoebian fauna, and sedimentology comprising the period from ca. A.D. 1890 to the present. Although the predicted changes in water quality (limnological impact) were not as significant as that observed in nearby Swan Lake, or in Crawford Lake, the same anthropogenic-induced alterations of the landscape caused a disturbance to the aquatic ecosystem in Haynes Lake, and these effects remain evident in the modern lake habitat. 


\section{References}

Anderson NJ (1995) Using the past to predict the future: lake sediments and the modelling of limnological disturbance. Ecol Model 78: 149-172.

Appleby PG, Nolan PJ, Gifford DW, Godfrey MJ, Oldfield F, Anderson NJ, Battarbee RW (1986) ${ }^{210} \mathrm{~Pb}$ dating by low background gamma counting. Hydrobiologia 143: 21-27.

Appleby PG, Oldfield F (1978) The calculation of lead-210 dates assuming a constant rate of supply of unsupported ${ }^{210} \mathrm{~Pb}$ to the sediment. Catena 5: 18.

Archives of Ontario (1979) Ontario Archives land record index township listing, p. 3387.

Austin SJ (1994) The Wilcox Lake site (AlGu-17): Middle Iroquoian exploitation of the Oak Ridges Moraine. Ontario Archaeology 58: 49-84.

Beaver J (1981) Apparent ecological characteristics of some common freshwater diatoms. Ontario Ministry of the Environment. Don Mills, Ontario, 513 pp.

Binford MW (1990) Calculation and uncertainty analysis of ${ }^{210} \mathrm{~Pb}$ dates for PIRLA project lake sediment cores. J Paleolimnol 3: 253-267.

Burden ET, McAndrews JH, Norris G (1986a) Palynology of Indian and European forest clearance and farming in lake sediment cores from Awenda Provincial Park, Ontario. Can J Earth Sci 23: 43-54.

Burden ET, Norris G, McAndrews JH (1986b) Geochemical indicators in lake sediment of upland erosion caused by Indian and European farming, Awenda Provincial Park, Ontario. Can J Earth Sci 23: 55-65.

Camburn KE, Charles DF (2000) Diatoms of Low-Alkalinity Lakes in the Northeastern United States. The Academy of Natural Sciences :Philadelphia, USA. 152 pp.

Canniff W (1869) History of the Settlement of Upper Canada, (Ontario) with Special Reference to The Bay of Quinte. Dudley and Burns, Printers, Victoria Hall, Toronto, $666 \mathrm{pp}$.

Chapman LJ, Putnam DF (1966) The physiography of southern Ontario. University of Toronto Press, Toronto, $386 \mathrm{pp}$. 
Deevey ESJ (1965) Sampling Lake Sediments by use of the Livingstone Sampler. In: Kummel B, Raup D (eds) Handbook of Paleontological Techniques. W.H. Freeman and Company, San Francisco and London.

Dixit SS, Dixit AS, Smol JP (2002) Diatom and chrysophyte transfer functions and inferences of post-industrial acidification and recent recovery trends in Killarney lakes (Ontario, Canada). J Paleolimnol 27: 79-96.

DMTI Spatial Inc (2003) Esri Data and Maps. Canada Water Bodies. Redlands California, USA.

Ekdahl EJ, Teranes JL, Wittkop CA, Stoermer EF, Reavie ED, Smol JP (2007) Diatom assemblage response to Iroquoian and Euro-Canadian eutrophication of Crawford Lake, Ontario, Canada. J Paleolimnol 37: 233246.

Enache M, Prairie YT (2002) WA-PLS diatom-based pH, TP and DOC inference models from 42 lakes in the Abitibi clay belt area (Quebec, Canada). J Paleolimnol 27: 151-171.

Fallu MA, Allaire N, Pienitz R (2000) Freshwater Diatoms from northern Québec and Labrador (Canada). J. Cramer. Stuttgart, Germany. 200 pp.

Gentilcore RL, Wood D (1978) A Military Colony in a Wilderness: The Upper Canada Frontier. In: Wood JD (ed) Perspectives on Landscape and Settlement in Nineteenth Centry Ontario. The MacMillan Company of Canada Ltd., Toronto, pp 32-42.

Gerber RE, Howard K (2002) Hydrogeology of the Oak Ridges Moraine aquifer system: implications for protection and management from the Duffins Creek watershed. Can J Earth Sci 39(9): 1333-1348.

Germain H (1981) Flore des Diatomées Diatomophycées eaux douces et saumâtres du massif Armoricain et des contrées voisines d'Europe occidentale. Société Nouvelle Des Éditions Boubée. Paris. 436 pp.

Google Earth ${ }^{\mathrm{TM}}$ Mapping Service (2007) http://downloadingnow.com/googleearth/1/ Cited 24 February 2008.

Guillet EC (1933) Pioneer Travel in Upper Canada. University of Toronto Press, Toronto, $241 \mathrm{pp}$.

Guillet EC (1946) Pioneer Life in the County of York. Hess-Trade Typesetting Company, Toronto, $166 \mathrm{pp}$. 
Hall RI, Smol JP (1996) Paleolimnological assessment of long-term water-quality changes in south-central Ontario lakes affected by cottage development and acidification. Can J Fish Aquat Sci 53: 1-17.

Hammer BK, Stoermer EF (1997) Diatom-based interpretation of sediment banding in an urbanized lake. J Paleolimnol 17: 437-449.

Jahn R, Kociolek JP, Witkowski A, Compère P (ed) (2001) Studies on Diatoms. A.R.G. Gantner Verlag K.G. Germany. 633 pp.

Juggins S (2005) C2 Version 1.5: Software for ecological and paleoecological data analysis and visualization.

http://www.campus.ncl.ac.uk/staff/Stephen.Juggins/software/C2Home.htm . Cited 14 January 2008.

Kapches M (1981) The Middleport Pattern in Ontario Iroquoian Prehistory, PhD dissertation, University of Toronto.

Karrow PF (1989) Quaternary geology of the Great Lakes Subregion. In: Fulton RJ (ed) Quaternary Geology of Canada and Greenland. Geological Survey of Canada, Geology of Canada, No.1, pp 326-350.

Krammer K (1997a) Die Cymbelloiden Diatomeen: Eine Monographie der wetweit bekannten Taxa Teil 1. Allgemeines und Encyonema Part. J. Cramer. Stuttgart, Germany $382 \mathrm{pp}$.

Krammer K (1997b) Die cymbelloiden Diatomeen Eine Monographie der weltweit bekanten Taxa Teil 2. Encyonema part., Encyonopsis and Cymbellopsis. J. Cramer. Stuttgart, Germany. 469 pp.

Krammer K (2000) Diatoms of Europe: Diatoms of the European Inland Waters and Comparable Habitats.vol 1 The genus Pinnularia, (ed) Horst LangeBertalot. A.R.G. Gantner Verlag K.G. Germany 703 pp.

Krammer K (2002) Diatoms of Europe: Diatoms of the European Inland Waters and Comparable Habitats.vol 3 Cymbella (ed) Horst Lange-Bertalot. A.R.G. Gantner Verlag K.G. Germany 584 pp.

Krammer K (2003) Diatoms of Europe: Diatoms of the European Inland Waters and Comparable Habitats.vol 4 Cymopleura, Delicata, Navicymbula, Gomphocymbellopsis, Afrocymbella, (ed) Horst Lange-Bertalot. A.R.G. Gantner Verlag K.G. Germany 530 pp.

Krammer K (1997) Die Cymbelloiden Diatomeen: Eine Monographie der wetweit bekannten Taxa Teil 1. Allgemeines und Encyonema Part. J. Cramer. Stuttgart, Germany $382 \mathrm{pp}$. 
Krammer K (1997) Die cymbelloiden Diatomeen Eine Monographie der weltweit bekanten Taxa Teil 2. Encyonema part., Encyonopsis and Cymbellopsis. J. Cramer. Stuttgart, Germany. $469 \mathrm{pp}$.

Krammer K, Lange-Bertalot H (1986) Bacillariophyceae Süßwasserflora von Mitteleuropa, 2/1. Teil: Naviculaceae. Gustav Fischer Verlag Stuttgart, New York, 876 pp.

Krammer K, Lange-Bertalot H (1988) Bacillariophyceae Süßwasserflora von Mitteleuropa, 2/2. Teil: Bacillariaceae, Epithemiaceae, Surirellaceae. Gustav Fischer Verlag Stuttgart, New York, 596 pp.

Krammer K, Lange-Bertalot H (1991a) Bacillariophyceae Süßwasserflora von Mitteleuropa, 2/3. Teil: Centrales, Fragilariaceae, Eunotiaceae. Gustav Fischer Verlag Stuttgart, New York, 576 pp.

Krammer K, Lange-Bertalot H (1991b) Bacillariophyceae Sü $\beta$ wasserflora von Mitteleuropa, 2/4. Teil: Achnanthaceae, Kritische Ergänzungen Zu Navicula (Lineolatae) und Gomphonema Gesamtliteraturverzeichnis Teil 1-4. Gustav Fischer Verlag Stuttgart, New York, 437 pp.

Krammer K, Lange-Bertalot H (2000) Bacillariophyceae Part 5. (ed) Büdel B, Gärtner G, Krienitz L, Lokhorst GM. Spektrum Akademischer Verlag Heidelberg, Berlin, Germany. 311 pp.

Kumar A, Dalby AP (1998) Identification key for holocene lacustrine arcellacean (thecamoebian) taxa. http://palaeoelectronica.org/1998 1/dalby/issue1.htm.

Kumar A, Patterson RT (2000) Arcellaceans (thecamoebians): new tools for monitoring long- and short-term changes in lake bottom acidity. Environ Geol 39: 689-697.

Lange-Bertalot $\mathrm{H}$ (2001) Diatoms of Europe: Diatoms of the European Inland Waters and Comparable Habitats.vol 2 Navicula sensu stricto, 10 Genera Separated from Navicula sensu lato, Frustulia, (ed) Horst Lange-Bertalot. A.R.G. Gantner Verlag K.G. Germany 526 pp.

Lange-Bertalot H, Krammer K (1989) Achnanthes eine Monographie der Gattung mit Definition der Gattung Cocconeis und Nachträgen zu den Naviculaceae. J. Cramer. Stuttgart, Germany. 393 pp.

Lange-Bertalot H, Külbs K, Lauser T, Nörpel-Schemp M, Willman M (1996) Diatom Taxa introduced by Georg Krasske Documentation and Revision. Koeltz Scientific Books. Germany. 358 pp. 
Langman RC (1971) Patterns of Settlement in Southern Ontario. McClelland and Stewart Limited, Toronto, $140 \mathrm{pp}$.

McAndrews JH, Turton CL (2007) Canada Geese dispersed cultigen pollen grains from prehistoric iroquoian fields to Crawford Lake, Ontario, Canada. Palynology 31: 9-18.

McGill University (2001) The Canadian County Atlas Digital Project.

http://digital.library.mcgill.ca/CountyAtlas/SearchMapframes.php. Cited 13 January 2008.

Meltzeltin D, Lange-Bertalot H, García-Rodríguez A (2005) Diatoms of Uruguay Compared with other taxa from South America and elsewhere. A.R.G. Gantner Verlag K.G. Germany. 736 pp.

Natural Resources Canada (2002) GeoBase Geopolitical boundaries - Level 1. Ottawa, Ontario, Canada.

Pappas JL, Stoermer EF (1996) Quantitative methods for determining a representative algal count. J Phycol 32: 693-696.

Patrick R, Reimer CW (1966) The diatoms of the United States Exclusive of Hawaii. Vol. 1. Fragilariaceae, Eunotiaceae, Achnanthaceae, Naviculaceae. The Academy of Natural Sciences of Philadelphia. USA. $688 \mathrm{pp}$.

Patrick R, Riemer CW (1975) The Diatoms of the United States Exclusive of Alaska and Hawaii. Vol. 2 Part 1. Entomoneidaceae, Bymbellaceae, Gomphonemaceae, Epithemiaceae. The Academy of Natural Sciences of Philadelphia. USA. 213 pp.

Patterson RT, Dalby A, Kumar A, Henderson LA, Boudreau REA (2002) Arcellaceans (thecamoebians) as indicators of land-use change: settlement history of the Swan Lake area, Ontario as a case study. J Paleolimnol 28: 297-316.

Patterson RT, Fishbein E (1989) Re-examination of the statistical methods used to determine the number of point counts needed for micropaleontological quantitative research. J Paleontol 63: 245-248.

Patterson RT, Kumar A (2002) A review of current testate rhizopod (thecamoebian) research in Canada. Palaeogeogr Palaeoclimatol Palaeoecol 180: 225-251. 
Potapova M, Hamilton PB (2007) Morphological and ecological variation within the Achnanthidium minutissimum (Bacillariophyceae) species complex. $\mathrm{J}$ Phycol 43: 561-575.

Reavie ED, Hall RI, Smol JP (1995) An expanded weighted-averaging model for inferring past total phosphorus concentrations from diatom assemblages in eutrophic British Columbia (Canada) lakes. J Paleolimnol 14: 49-67.

Reavie ED, Smol JP (1998) Freshwater diatoms from the St. Lawrence River. (ed) Lange-Bertalot H, Kociolek P. J. Cramer. Stuttgart, Germany. 137 pp.

Reavie ED, Smol JP (2001) Diatom-environmental relationships in 64 alkaline southeastern Ontario (Canada) lakes: a diatom-based model for water quality reconstructions. J Paleolimnol 25: 25-42.

Reichardt E (1999) Zur Revision der Gattung Gomphonema Die Arten um G. affine/insigne, $G$. aungustatum/micropus, $G$. acuminatum sowie gomphonemoide Diatomeen aus dem Oberoligozäm om Böhmen. A.R.G. Gantner Verlag K.G. Germany. 203 pp.

Round FE, Crawford RM, Mann DG (1990) The Diatoms: Biology and Morphology of the Genera. Cambridge University Press. New York, USA. $747 \mathrm{pp}$.

Sanderson EW, Jaiteh M, Levy MA, Redford KH, Wannebo AV, Woolmer G (2002) The Human Footprint and the Last of the Wild. Bioscience 52: 891904.

Sharpe D, Pugin A, Pullan S, Shaw J (2004) Regional unconformities and the sedimentary architecture of the Oak Ridges Moraine area, southern Ontario. Can J Earth Sci 41: 183-198.

Siver PA (1999) Development of paleolimnological inference models for $\mathrm{pH}$, total nitrogen and specific conductivity based on planktonic diatoms. J Paleolimnol 21: 45-59.

Siver PA, Hamilton PB, Stachura-Suchoples' K, Kociolek JP (2005) Diatoms of North America, the freshwater flora of Cape Cod, Massachusetts, U.S.A. Iconographia Diatomologica 14:1-463.

Smith DB (1989) The Dispossession of the Mississauga Indians: a Missing Chapter in the Early History of Upper Canada. In: Johnson JK, Wilson BG (eds.) Historical Essays on Upper Canada, New Perspectives. Carleton University Press, Ottawa, pp. 23-43. 
Sorvari S, Korhola A (1998) Recent diatom assemblage changes in subarctic Lake Saanajärvi, NW Finnish Lapland, and their paleoenvironmental implications. J Paleolimnol 20: 205-215.

Stamp RM (1991) Early Days in Richmond Hill: A History of the Community to 1930. Richmond Hill Public Library Board, Ch. $1 \& 2$.

http://edrh.rhpl.richmondhill.on.ca/default.asp?ID=s2.2 Cited 17 February 2008.

Statistics Canada (2007a) Population and dwelling counts, for Canada, census metropolitan areas census agglomerations and census subdivisions (municipalities), 2006 and 2001 censuses.

http://www12.statcan.ca/english/census06/data/popdwell/Table.cfm?T=20 $\underline{5 \& R P P}=50$. Cited 13 January 2008.

Statistics Canada (2007b) Population and dwelling counts, for Canada, census metropolitan areas census agglomerations and census subdivisions (municipalities), 2006 and 2001 censuses. http://www12.statcan.ca/english/census06/data/popdwell/Table.cfm? T =30 $3 \& \mathrm{CMA}=535 \& \mathrm{~S}=0 \& \mathrm{O}=\mathrm{A} \& \mathrm{RPP}=25 \#$ FootCSDType. . Cited 4 November 2007.

Statistics Canada (2001) Province of Ontario Data Spatial Files. Statistical Reference Centre. (National Capital Region), Ottawa, Ontario, Canada.

Trombulak SC, Frissell CA (2000) Review of Ecological Effects of Roads on Terrestrial and Aquatic Communities. Conserv Biol 14: 18-30.

Van de Vijver B, Beyens L, Lange-Bertalot H (2004) The Genus Stauroneis in the Arctic and (Sub-) Antarctic Regions. J. Cramer. Stuttgart, Germany. 317 pp.

Warrick G (2000) The Precontact Iroquoian Occupation of Southern Ontario. Journal of World Prehistory 14: 415-466.

Watchorn MA, Hamilton PB, Anderson TW, Roe HM, Patterson RT (2008) Diatoms and pollen as indicators of water quality and land use change: a case study from the Oak Ridges Moraine, Southern Ontario, Canada. J Paleolimnol 39: 491-509.

Werum M, Lange-Bertalot $\mathrm{H}$ (2004) Diatoms in Springs from Central Europe and elsewhere under the influence of hydrogeology and anthropogenic impacts. A.R.G. Gantner Verlag K.G. Germany. 417 pp. 
Whitelaw GS, Eagles PFJ (2007) Planning for Long, Wide Conservation Corridors on Private Lands in the Oak Ridges Moraine, Ontario, Canada. Conserv Biol 21: 675-683. 
Chapter 3. A paleolimnological study of meromictic Teapot Lake, Ontario 


\section{Abstract}

Teapot Lake $\left(43^{\circ} 45^{\prime} 14^{\prime \prime} \mathrm{N} ; 7^{\circ} 48^{\prime} 14^{\prime \prime} \mathrm{W}\right)$ is a small lake located within the Greater

Toronto Area (GTA). Study of the water column indicated it is meromictic, therefore analysis of the sediment should provide an accurate record of past water conditions. Pollen and diatoms extracted from the sediment dated from ca. 5600 YBP to the present indicate only slight changes in the aquatic ecosystem concomitant with anthropogenic changes to the landscape for agriculture and housing by both Iroquoian inhabitants (ca. 500 A.D. to 1500 A.D.) and by European settlers (ca. A.D. 1850). Furthermore, changes in diatom-inferred $\mathrm{pH}$ and total phosphorus were not significant and subject to large error. This is contrary to many other published studies, indicating either the sediment record of Teapot Lake has been disturbed, or that excess phosphorus in the aquatic ecosystem is not available for diatom growth. It is possible that much of the available phosphorus doesn't circulate into the epilimnion due to the meromictic nature of Teapot Lake, and remains in the hypolimnion. Excess phosphorus becomes bound with iron and manganese observed in high concentrations below the thermocline to produce either iron-phosphates or manganese-phosphates. 


\section{Introduction}

Meromictic lakes are noted for archiving detailed, undisturbed sediment records that are useful for studying lake histories since anoxic bottom waters preclude the presence of bioturbators (Cohen 2003; Ekdahl et al. 2007; Rybak and Dickman 1988; Smol et al. 1983). Biological proxies such as diatoms respond rapidly to any changes in lake ecosystems and will thus provide a detailed record of limnological change, particularly in the undisturbed sediments of meromictic lakes. Models developed based on observed diatom assemblages have been shown to be able to predict past water quality variables based on current optima (Anderson 1995; Hall and Smol 1996; Hall and Smol 1999; Patrick and Reimer 1966; Reavie and Smol 2001; Watchorn et al. 2008).

Palynology has also been proven to be a useful paleolimnolocal tool for determining past changes in the landscape, and for providing estimates for ages of sediment deposited in lakes (Allison et al. 1986; Bennett and Fuller 2002; Bhiry and Filion 1996; Boucherle et al. 1986; Burden et al. 1986; Chalcote 2003). If used together, pollen and diatoms can provide a multiproxy paleolimnological lake history, and can be used to determine if there was a correlation between changes in the terrestrial ecosystem and changes in the aquatic ecosystem (Boucherle et al. 1986; St. Jacques et al. 2000; Watchorn et al. 2008)

Previous qualitative assessments and limited water property data collection from Teapot Lake, Heart Lake Conservation Area, Brampton, Ontario suggested that 
the lake may be meromictic, since it is very small, deep and surrounded by a $100 \mathrm{~m}$ wide wind-blocking forest screen (Don Ford, Toronto and Region Conservation Authority (TRCA), personal communication 2005). Determination that the lake is meromictic would be very useful, as interpretation of the contained sedimentary record might provide an accurate record of changes to the aquatic ecosystem as a result of anthropogenic changes to the landscape in the Greater Toronto Area (GTA), a region that has changed drastically as a result of settlement and massive population growth, particularly in the adjacent Brampton area (Canniff 1869; Statistics Canada 2007).

The purpose of this study was to collect water property data from Teapot Lake over an extended period of time to determine whether the lake was, in fact, meromictic, and to determine if diatoms and pollen extracted from a Holocene sediment core could detect changes in the aquatic ecosystem concomitant with anthropogenic disturbances to the adjacent landscape. 


\section{Materials and methods}

\section{Study area}

Teapot Lake is located in the Etobicoke Creek Watershed within the Heart Lake Conservation Area. The lake is $8 \mathrm{~km}$ north of the city of Brampton and on the Brampton Esker (Fig. 1). The Brampton Esker is about $8 \mathrm{~km}$ long and $1.8 \mathrm{~km}$ wide and formed during the retreat of the Lake Ontario ice lobe from the Brampton area ca. 13,300 YBP (Karrow et al. 1977; Motz and Morgan 2001). The esker is composed of course glaciofuvial sands and gravels, and is capped by a layer of clay till. The esker is an important aquifer and source of groundwater, with the sands and gravels holding and purifying water as it percolates downwards. The esker has been, and continues to be, an important source of aggregate for construction and road building in the Brampton area. The Heart Lake Conservation Area contains 43.5 hectares of deciduous, coniferous and mixed forest. This is the largest block of forest in a highly fragmented landscape (Karrow et al. 1977; Motz and Morgan 2001; TRCA 1998).

Teapot Lake $\left(43^{\circ} 45^{\prime} 14^{\prime \prime} \mathrm{N} ; 79^{\circ} 48^{\prime} 14^{\prime \prime} \mathrm{W}\right)$ is a very small but deep lake, measuring approximately $125 \mathrm{~m}$ wide and $125 \mathrm{~m}$ across, with a maximum depth of $12 \mathrm{~m}$, and is located about $255 \mathrm{~m}$ above mean sea-level (AMSL). It is surrounded on all sides by an approximately $100 \mathrm{~m}$ wide band of thick forest cover consisting of a mixture of birch (Betula spp.), spruce (Picea spp.), pine (Pinus spp.), maple (Acer spp.), alder (Alnus spp.), poplar (Populus spp.), ash (Fraxinus spp.), tamarack (Larix spp.), highbush cranberry (Vaccinium spp.), and willow (Salix spp.). 
Beyond the forested area, there is a mixture of farm, residential and commercial land uses supported by a substantial road network. 


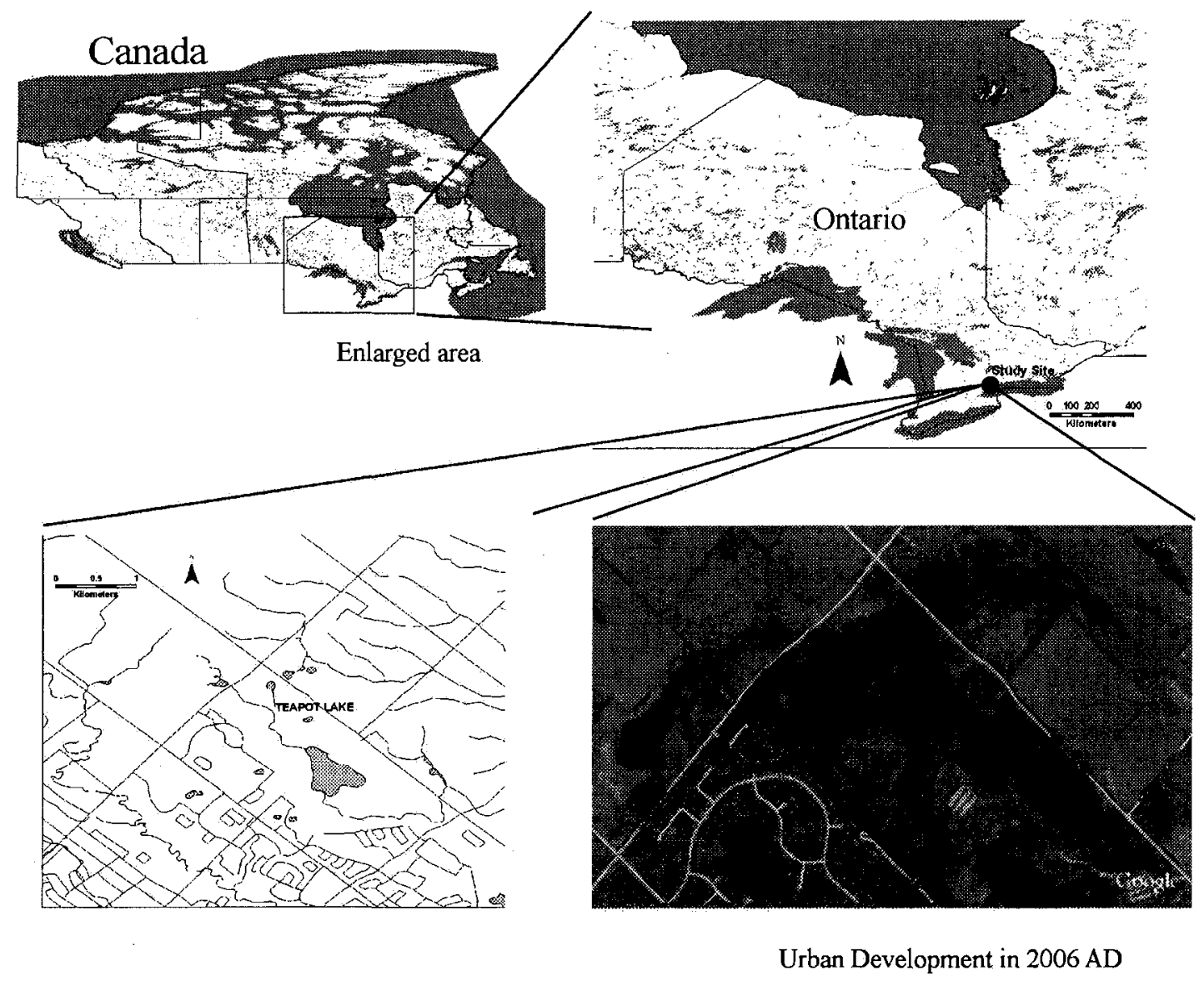

Fig. 1. Site map of Teapot Lake, Ontario, Canada.

(DMTI Spatial Inc. 2003; Google Earth ${ }^{\text {TM }}$ Mapping Service 2007; Natural Resources Canada 2002; Statistics Canada 2001) 


\section{Sedimentology and sediment core details}

One sediment core was collected in five sections measuring $109.0 \mathrm{~cm}$ (TPLC21), $97.0 \mathrm{~cm}$ (TPLC2-2), $108.0 \mathrm{~cm}$ (TPLC2-3), $107.5 \mathrm{~cm}$ (TPLC2-4), and $75.0 \mathrm{~cm}$ (TPLC2-5), for a total of $496.5 \mathrm{~cm}$. The core was extracted from the center of

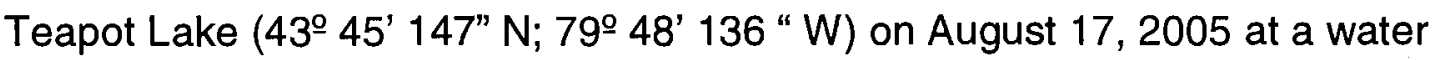
depth of $12 \mathrm{~m}$, using a Livingstone corer (Deevey 1965). Five other sediment cores were collected from Teapot Lake to provide material for dating, and for separate studies utilizing other proxies.

The five sections of the core were x-rayed to identify any subtle sedimentary features, and to recognize in particular, any laminar structure, with a Kevex x-ray machine at $40 \mathrm{kV}$, and $27 \mathrm{~mA}$, with exposure times ranging from $90-180$ seconds. The images were captured on erasable phosphor plates and digitally recovered using an OREX scanner with VideoRen $®$ software (version 1.0).

\section{Chronology}

Thirteen samples from Teapot Lake Core TPLC1-1, from $0-18.9 \mathrm{~cm}$ core depth, were sent to the Science Museum of Minnesota for ${ }^{210} \mathrm{~Pb}$ dating analysis. Core TPLC1-1 was taken from the same location as core TPLC2 (sections 1 through 5), which is the core that was used for diatom analysis. Dates and sedimentation rates were determined according to the c.r.s. (constant rate of supply) model (Appleby et al. 1986; Appleby and Oldfield 1978) with confidence intervals calculated by first-order error analysis of counting uncertainty (Binford 1990). 
Several samples (TPLC2-3-35 [bulk sediment; 750 mg]; TPLC2-4-80 [bulk sediment; 634 mg]; TPLC4-3-4-5 [bulk sediment; 106 mg]; TPLC4-8-2-3 [bulk sediment; $876 \mathrm{mg}$ ]; TPLC1-5A 1-2 [wood fragment]) from Teapot Lake were sent to IsoTrace Radiocarbon Laboratory (University of Toronto) for ${ }^{14} \mathrm{C}$-dating analysis. Two or four separate analyses (normal precision) were conducted on each sample, correcting for natural and sputtering isotope fractionation. Results were measured using the ${ }^{13} \mathrm{C} /{ }^{12} \mathrm{C}$ ratio, with sample age quoted as an uncalibrated conventional radiocarbon date in years before present (YBP), using the Libby ${ }^{14} \mathrm{C}$ mean life of 8033 years. The error represents the $68.3 \%$ confidence limit.

Due to the difficulties associated with obtaining reliable ${ }^{14} \mathrm{C}$ dates from Teapot Lake, palynology was used as an important tool for not only gaining information about the Holocene ecology of the area surrounding the lake, but to also chronologically constrain the Holocene history of the core.

\section{Pollen Preparation and Enumeration}

Pollen preparation followed methods described by Fægri and Iversen (1989).

Forty-two $50 \mathrm{~mm}^{3}$ aliquots of wet sediment from Teapot Lake sediment cores TPLC2-1, TPLC2-2. TPLC2-3, TPLC2-4, and TPLC2-5 were subjected to hot treatments of $10 \%$ hydrochloric acid and $10 \%$ potassium hydroxide followed by acetolysis. Sieving and hydrofluoric acid treatments were omitted. Slurries were stained with safranin, dehydrated sequentially with alcohol, and stored in silicone oil. One tablet containing a known quantity of Lycopodium clavatum spores was 
added to the majority of samples prior to processing in order to calculate pollen concentrations (batch No. 938 934, n=10,679 +/- 953 std. error spores/tablet; Benninghoff 1962; Stockmarr 1971). There was, unfortunately, an insufficient quantity of spores to spike each sample. Pollen and spores were identified and counted at 500x magnification with an Olympus BX50 transmitted light microscope. Total terrestrial pollen and spores counted per slide were consistently above 300 , and more frequently above 400 , except at one horizon $(131 \mathrm{~cm})$ where 257 grains and spores were enumerated.

Pollen keys by McAndrews et al. (1988), Fægri and Iversen (1989), and Kapp et al. (2000) aided pollen identification. Pinus pollen was identified as diploxylontype, haploxylon-type, or was classified as undifferentiated (Fægri and Iversen 1989). Juniperus and Thuja occidentalis pollen were grouped together as Cupressaceae since their pollen is difficult to differentiate using light microscopy. Pteropsida (monolete) spores include all monolete members of the class Pteridophyta.

\section{Pollen Data Analysis}

The main pollen sum includes all total terrestrial pollen and spores, including fern spores since this group constitutes an important component of the modern vegetation of Ontario. The frequency of aquatic taxa, fungal spores, Nymphaea hairs, Pediastrum, sponge spicules, and microscopic charcoal was calculated from the total pollen sum. Calculation of absolute pollen abundance followed Stockmarr (1971). Percentage and concentration pollen data were graphed using 
Tilia version 2.0 (Grimm 1993). The CONISS program for stratigraphically constrained cluster analysis using a square root data transformation was applied to aid pollen diagram zonation (Gordon and Birks 1976; Grimm 1987; Fægri and Iversen 1989).

\section{Diatom Preparation and Enumeration}

Diatoms were used as a biological proxy in this study to infer changes in lake water properties through time. Diatoms deposited in Teapot Lake sediment were analyzed by extracting them from forty-two subsamples distributed from $1-410 \mathrm{~cm}$ throughout four sections of Core TPLC2 (TPLC2-1, TPLC2-2, TPLC23, TPLC2-4).

Approximately $1 \mathrm{cc}$ of wet sediment was extracted, weighed and freeze-dried from each subsample. The subsamples were then prepared for diatom analysis by weighing out $0.0200 \mathrm{~g}-0.0516 \mathrm{~g}$ of dry sediment. A $10 \mathrm{ml}$ solution of $50: 50$ nitric/sulfuric acids was added to each sediment sample and heated for approximately 20 minutes to remove organic material. The acid mixture was then diluted with distilled water and sonicated to disaggregate the diatom frustules into single valves. Subsequently, the acid was removed from the samples through centrifugation and a series of at least five distilled water dilutions. Finally, washed samples were stored for further processing in $45 \mathrm{ml}$ of distilled water.

Aliquots of $0.5 \mathrm{ml}$ from the washed diatom solution were pipetted onto $18 \mathrm{~mm} \mathrm{x}$ $18 \mathrm{~mm}$ coverglasses and allowed to air-dry. The coverglasses were fixed onto 
microscope slides with Naphrax ${ }^{\circledR}$ mountant. Two microscope slides were prepared for each sample; one for analysis with a Leica $\mathrm{DMR}^{\circledR}$ light microscope with phase contrast optics, and the others as reserve slides for cross-reference and verification. Prior to diatom counting, six scanning electron microscope stubs were prepared from six core horizons to identify small diatoms using an FEI XL Environmental Scanning Electron Microscope (ESEM). All of the quantified prepared microscope slides, the remaining subsample material, associated notes and photomicrographs are archived in the National Collection at the Canadian Museum of Nature, in Ottawa.

At least 600 diatoms were counted at $1600 \times$ magnification from each slide using a transect counting protocol (Pappas and Stoermer 1996; Watchorn et al. 2008). The number of valves per gram dry weight (total valves $\mathrm{g}^{-1} \mathrm{dwt}$ ) and percent abundance were subsequently calculated for each taxon. Flux rates were subsequently determined using ${ }^{210} \mathrm{~Pb}$ and sediment accumulation measures. The diatoms were identified using standard taxonomic references (e.g. Krammer 2003, 2002, 2000, 1997a, 1997b; Krammer and Lange-Bertalot 1988, 1986, 1991a, 1991b; Lange-Bertalot 2001; Patrick and Reimer 1966; Potapova and Hamilton 2007; Siver and Kling 1997).

\section{Diatom Data Analysis}

A diatom-water quality transfer function for Teapot Lake was developed following the format of Watchorn et al. (2008) using the program C2 version 1.5 (Juggins 2005). Fifty lakes from the Reavie and Smol (2001) calibration set that had 
complete data for spring growing conditions, including $\mathrm{pH}$, and total phosphorus (TP), were used as the calibration model to infer past water chemistry values in Teapot Lake. Lakes used in the calibration set are located $<300 \mathrm{~km}$ to the east of Teapot Lake and are situated on bedrock formations of limestone (Trenton and Beekmantown formations), granitic (Precambrian Shield) rock, or a mixture of the two (Chapman and Putnam 1966). Reconstruction of past water chemistry values for Teapot Lake were generated using 29 taxa from the fossil assemblage that were also found in the Reavie and Smol (2001) calibration set. The species relative abundance data was square-root transformed for weighted averaging (WA) analyses to reduce the effect of dominant taxa, as previously described in Reavie and Smol (2001).

\section{Water Property Measurements}

A profile through the lake water column of water property variables including temperature, dissolved oxygen, depth, conductance, $\mathrm{pH}$ and redox were measured using a Hydrolab Surveyor 3 on August 17, 2005, and on April 13, 2006. Samples of Teapot Lake water were also collected in plastic bottles for laboratory analysis at the Ottawa-Carleton Water Quality Laboratory for variables such as pH and TP on August 17 and 18, 2005, and on April 14, 2006.

Three Minilog-T temperature data loggers were moored from a permanent raft anchored at the center of Teapot Lake ( $\left.43^{\circ} 45^{\prime} 147^{\prime \prime} \mathrm{N} ; 79^{\circ} 48^{\prime} 136^{\prime \prime} \mathrm{W}\right)$ at $1 \mathrm{~m}$ (ID \# 1056E), 3m (ID \# 1055E), and 8m (ID \# 1044E) water depth on April 13, 2006. These data loggers were set to record hourly water temperatures from 
April 21, 2006 to March 16, 2007 for the purpose of determining whether the lake is truly meromictic.

Sub-bottom profiles of Teapot Lake were also collected in August 2005 using a Knudsen Engineering 320BP portable echosounder to determine the nature and shape of the bottom.

\section{Results}

\section{Sedimentology}

Visual inspection of the core indicated that the top $100 \mathrm{~cm}$ were primarily composed of gyttja, with no distinctive laminations observed. Digital x-ray analysis confirmed that Teapot Lake sediments from this core were not laminated through the top $100 \mathrm{~cm}$ (Fig. 2A), but that there were finely layered, planar laminations from about $100 \mathrm{~cm}$ depth to approximately $200 \mathrm{~cm}$ depth (Fig. 2B). Laminations were again absent from $200 \mathrm{~cm}$ to about $260 \mathrm{~cm}$ (Fig. 2C), while planar laminations were observed from $260 \mathrm{~cm}$ to about $315 \mathrm{~cm}$ (Fig. 2D). Sediments changed orientation frequently, and were, at times, sloped at a steep angle through the $315-350 \mathrm{~cm}$ (Fig. 2E) interval of the core. From $350 \mathrm{~cm}$ to the bottom of the analyzed portion of the core $(410 \mathrm{~cm})(\mathrm{Fig} .2 \mathrm{~F})$, finely-layered, flatlying laminations were again observed. 


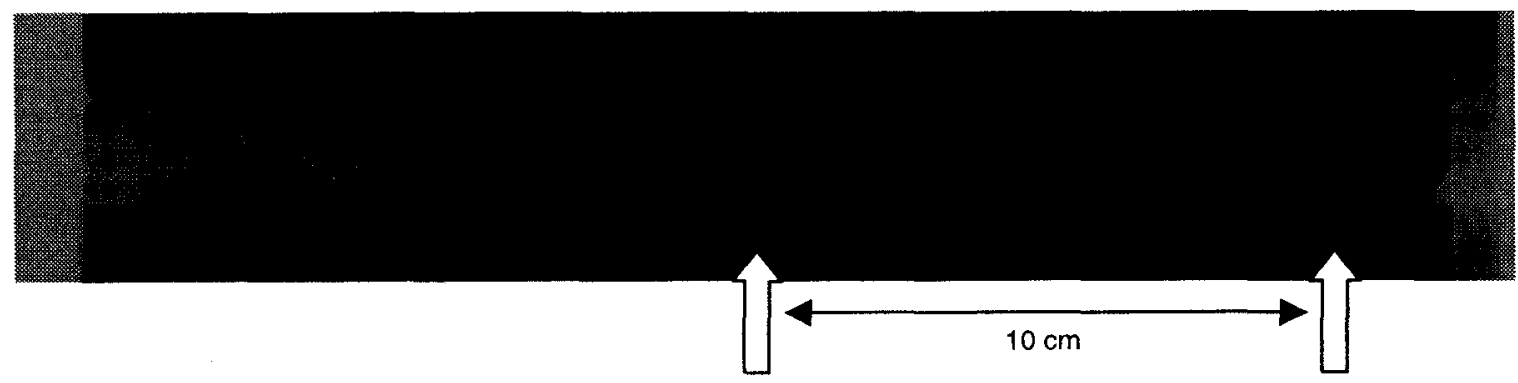

Fig. 2A. Teapot Lake Core x-ray: $\sim 20-40 \mathrm{~cm}$ depth from core TPLC2-1. The top direction is to the left.

Fig. 2B. Teapot Lake core x-ray: $\sim 130-150 \mathrm{~cm}$ depth from core TPLC2-2. The top direction is to the left.

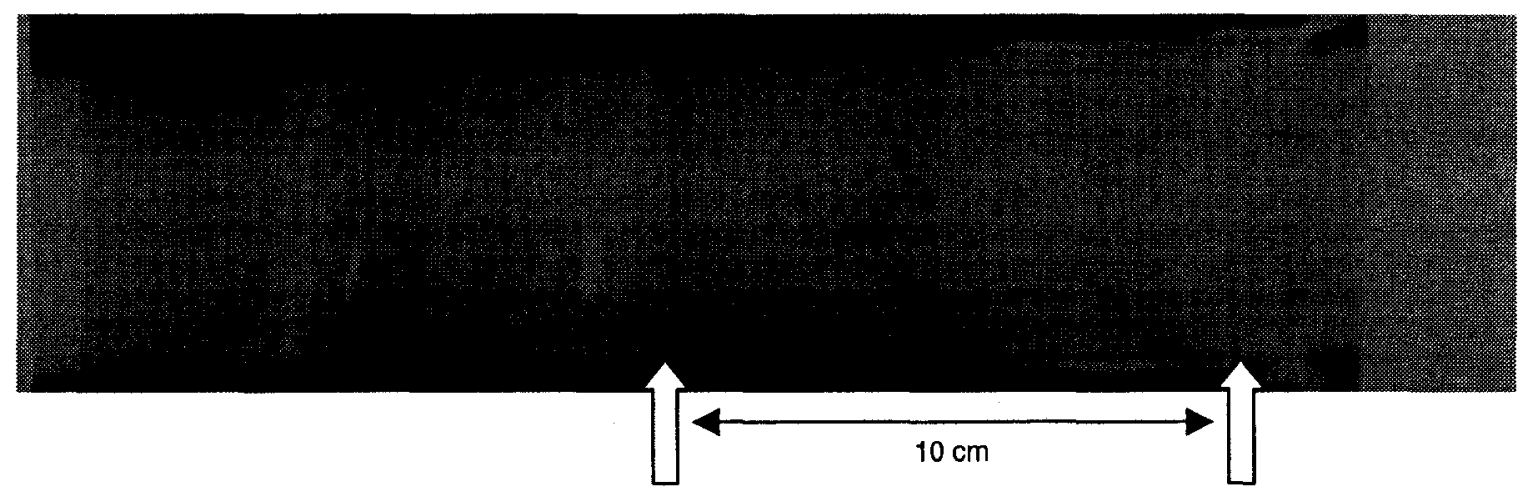

Fig. 2C. Teapot Lake Core $x$-ray: $\sim 180-206 \mathrm{~cm}$ depth from core TPLC2-2. The top direction is to the left. 


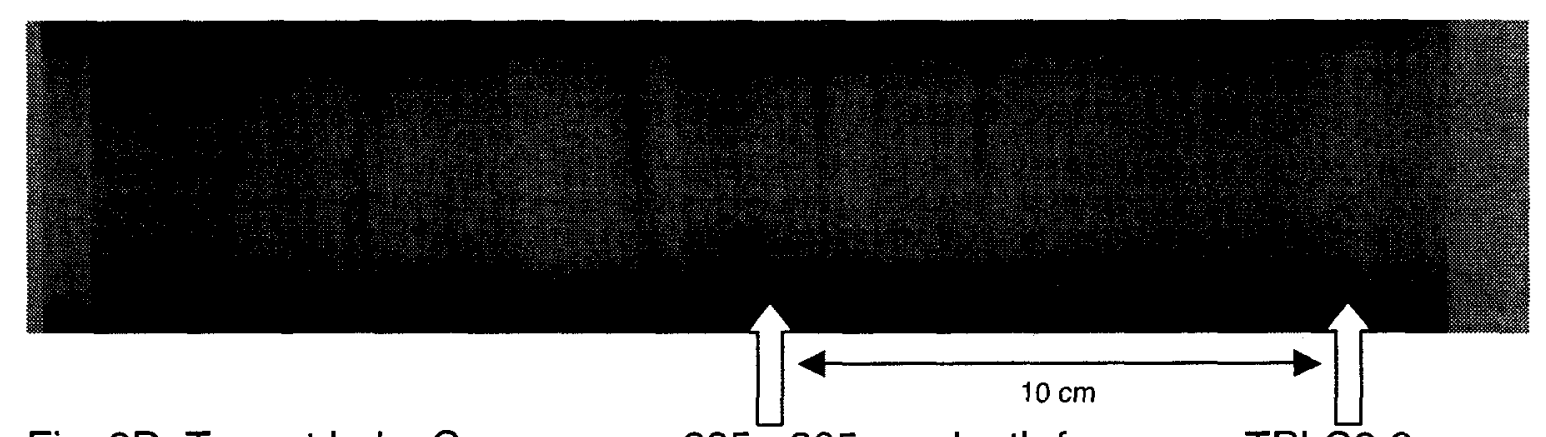

Fig. 2D. Teapot Lake Core $x$-ray: $\sim 285-305 \mathrm{~cm}$ depth from core TPLC2-3.

The top direction is to the left.

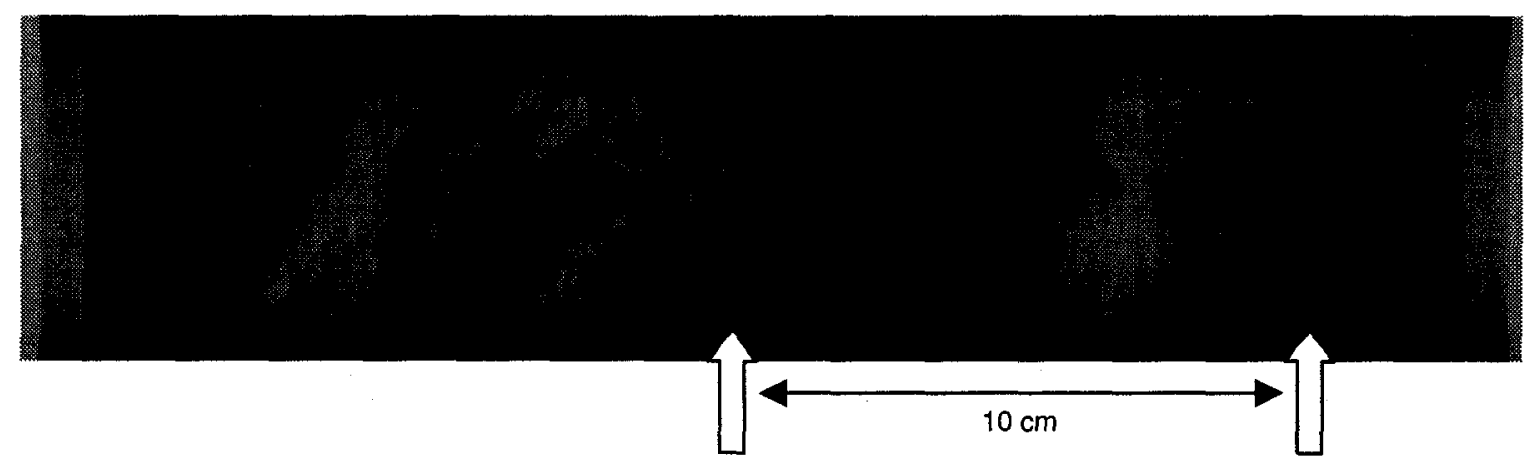

Fig. 2E. Teapot Lake Core x-ray: $~ 335-355 \mathrm{~cm}$ depth from core TPLC2-4. The top direction is to the left.

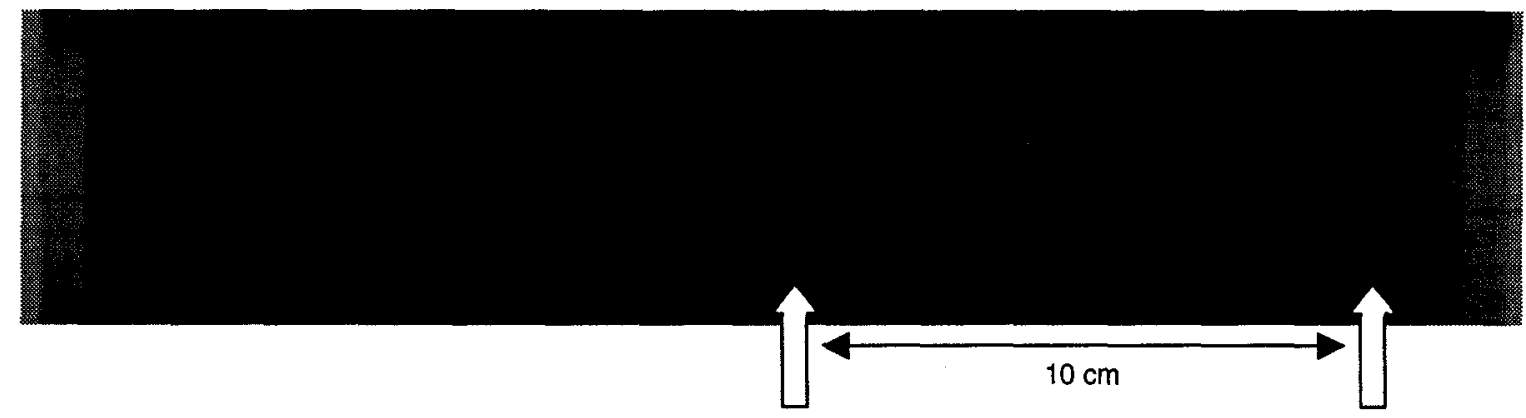

Fig. 2F. Teapot Lake core x-ray: $~ 375$ - $395 \mathrm{~cm}$ depth from core TPLC2-4. The top direction is to the left. 


\section{Palynology}

Fifty-two pollen and spore taxa were identified from forty-two horizons in the Teapot Lake sediment core TPLC2-1 through TPLC2-5 (Fig. 3). Four pollen assemblage zones were recognized based on CONISS and visual inspection.

\section{Zone TPZ-1 $(500-420 \mathrm{~cm})$}

Picea was the dominant pollen type in this basal zone, reaching over $30 \%$ abundance mid-zone ( $470 \mathrm{~cm}$ core depth), before declining. Quercus and Larix pollen were also relatively abundant in this zone. Tsuga canadensis began to increase mid-zone, following the decline in Picea pollen, and reached $20 \%$ abundance by the end of Zone TPZ-1.

\section{Zone TPZ-2 $(420-270 \mathrm{~cm})$}

Tsuga canadensis pollen continued to increase at the onset of this zone, and peaked at $25 \%$ abundance at $413 \mathrm{~cm}$ core depth, before declining to $\sim 3 \%$ at $399 \mathrm{~cm}$ depth. A biostratigraphic age of ca. 5400 calendar YBP has been applied to this decline (Fuller 1998; Bennett and Fuller 2002; Calcotte 2003). Fagus pollen increased abruptly at the beginning of this zone, and sustained a relative abundance from $10 \%$ to $20 \%$ throughout Zone TPZ-2. Tsuga canadensis pollen recovered at $320 \mathrm{~cm}$, and rose to $28 \%$ abundance at $277 \mathrm{~cm}$ core depth. A biostratigraphic age of ca. 3450 calendar YBP has been applied to the event at $320 \mathrm{~cm}$ core depth (Fuller 1998). Sponge spicules were also noted to increase in abundance through this zone, and fluctuated from $<1 \%$ to $10 \%$. 


\section{Zone TPZ-3 $(270-110 \mathrm{~cm})$}

Tsuga canadensis pollen declined at the beginning of this zone, concomitant with a slight increase in Fagus pollen, succeeded by a marginal rise in Betula pollen. Following the initial decline, T. canadensis pollen peaked to a core maximum of $\sim 40 \%$ at $187 \mathrm{~cm}$ depth. At $180 \mathrm{~cm}$ sediment depth, $T$. canadensis declined steeply to $6 \%$ abundance, but throughout the remainder of the zone, this pollen type fluctuated between $11 \%$ and $22 \%$ abundance. Trends in the relative abundance of $T$. canadensis were inversely mirrored by fluctuations in the frequency of microscopic charcoal, with a peak in abundance of $31 \%$ observed at $180 \mathrm{~cm}$ sediment depth. 


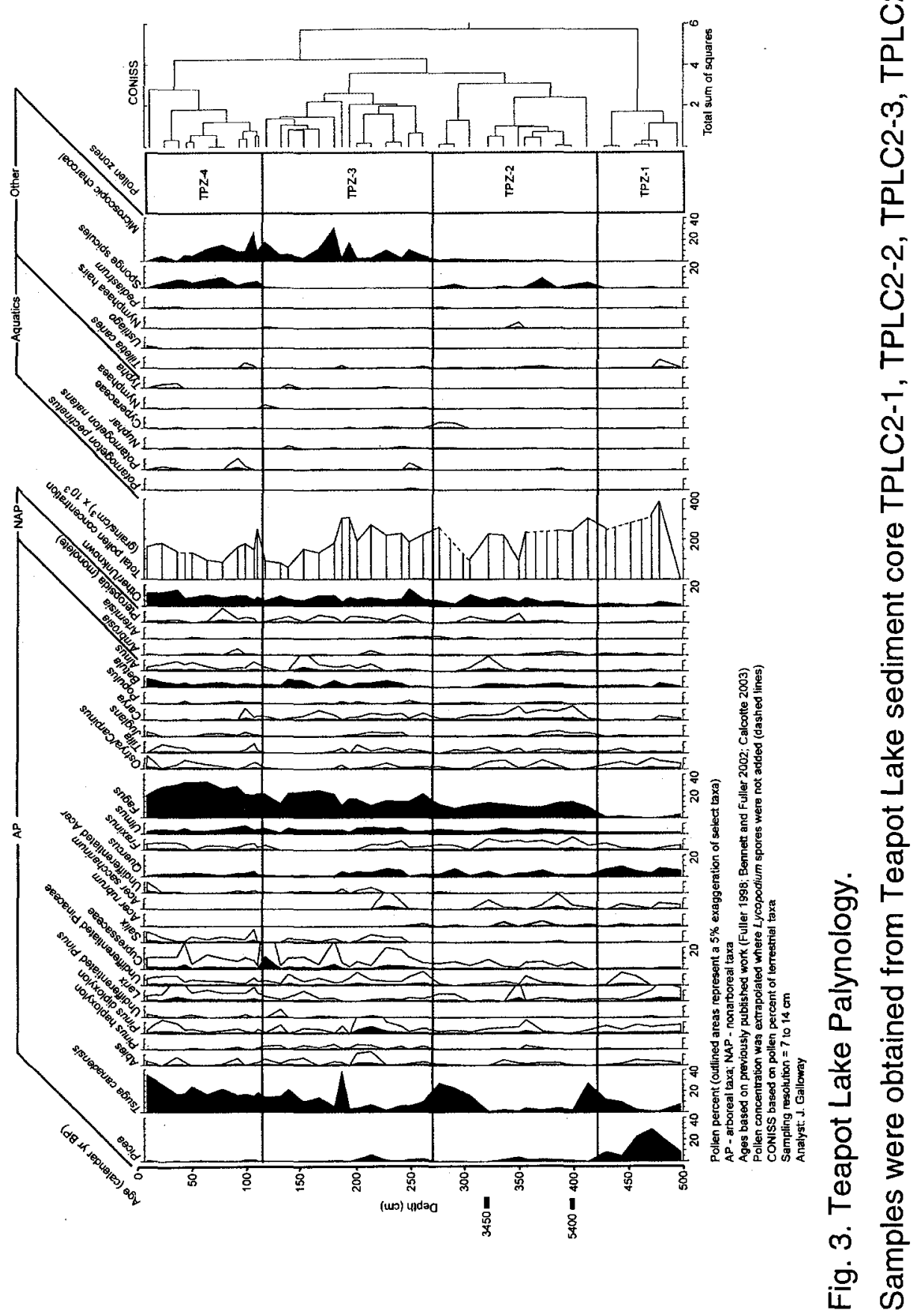




\section{Zone TPZ-4 (110-0 cm)}

Tsuga canadensis pollen continued to increase steadily throughout this zone, to reach $35 \%$ abundance near the top of the sediment core, at $8 \mathrm{~cm}$ depth. Fagus pollen also increased in Zone TPZ-4, and reached a core maximum of $30 \%$ abundance from $64 \mathrm{~cm}$ to $43 \mathrm{~cm}$ depth, before declining slightly to $21 \%$ abundance at $8 \mathrm{~cm}$ depth. Microscopic charcoal increased at the start of this zone to reach a peak abundance of $26 \%$ at $107 \mathrm{~cm}$ depth, then declined through to the top of the core. Sponge spicules were relatively abundant following nearabsence in the previous zone.

\section{Chronology}

Radiocarbon dating of four bulk sediment samples and one wood fragment sample did not provide any conclusive results (Paul Gammon, personal communication 2007). Two separate analyses of samples TPLC2-3-35 $(241 \mathrm{~cm}$ depth) and TPLC2-4-80 (400 cm depth), taken from core TPLC2, which was obtained from the center of Teapot Lake, indicated there was not enough material to indicate the age of the samples (Table 1). Analysis of a wood fragment from TPLC1-5A - 1-2 (474 cm core depth), taken from core TPLC1, also extracted from the center of Teapot Lake, indicated the fragment was less than 50 years of age, which is obviously erroneous. Two more bulk sediment samples were dated, this time from core TPLC4, which was taken from a second sampling location, closer to the shore. Four separate analyses of sample TPLC4-3-4-5 (88 $\mathrm{cm}$ core depth) indicated sediment age to be $1790+/-50$ YBP while four separate analyses of sample TPLC4-8-2-3 (582 cm depth), indicated sediment 
age to be $770+/-40$ YBP. These results were deemed to be highly inaccurate as younger sediments cannot accumulate on top of older sediments.

\begin{tabular}{|l|c|c|c|c|c|}
\hline \multicolumn{6}{|c|}{ Table 1. Teapot Lake Sediment and Wood Fragment ${ }^{14} \mathrm{C}$ Dating Results } \\
\hline Sample ID & Location & $\begin{array}{c}\text { Sediment } \\
\text { Depth } \\
\text { (cm) }\end{array}$ & $\begin{array}{c}\text { Sample } \\
\text { Description }\end{array}$ & $\begin{array}{c}\text { Sample } \\
\text { Weight } \\
\text { (mg) }\end{array}$ & $\begin{array}{c}\text { Age } \\
\text { (YBP) }\end{array}$ \\
\hline TPLC2-3-35 & center & 241 & sediment & 750 & no result \\
TPLC2-4-80 & center & 400 & sediment & 634 & no result \\
TPLC1-5A-1-2 & center & 474 & wood fragment & - & $<50$ \\
TPLC4-3-4-5 & near shore & 88 & sediment & 106 & $1790+/-50$ \\
TPLC4-8-2-3 & near shore & 582 & sediment & 876 & $770+/-40$ \\
\hline
\end{tabular}

Since the lower portion of the core could not be reliably dated using ${ }^{14} \mathrm{C}$ methods, palynology was used to chronologically constrain the portions of the core below where ${ }^{210} \mathrm{~Pb}$ dating was effective. The pollen derived age estimates and ${ }^{210} \mathrm{~Pb}$ dating indicated that the sediments recovered from the portion of the core examined for diatom assemblages span ca. 5600 YBP $(410 \mathrm{~cm})$ to ca A.D. 2001 $\left(1 \mathrm{~cm}\right.$ ), with a margin of error ranging from 1 to 25 years for the ${ }^{210} \mathrm{~Pb}$ data (from $1 \mathrm{~cm}$ to $18.9 \mathrm{~cm})$. Interpolation of these data using second order polynomial curves provided estimates for the ages of intervening sediment samples. Separate curves were used, with one curve used to interpolate dates in the top $30 \mathrm{~cm}$ using the ${ }^{210} \mathrm{~Pb}$ data $\left(\mathrm{R}^{2}=0.9873\right)$ and the second curve $\left(\mathrm{R}^{2}=0.9993\right)$ used all of the data to interpolate approximate dates derived from palynological analysis for the rest of the core (Fig. 4A, 4B). 


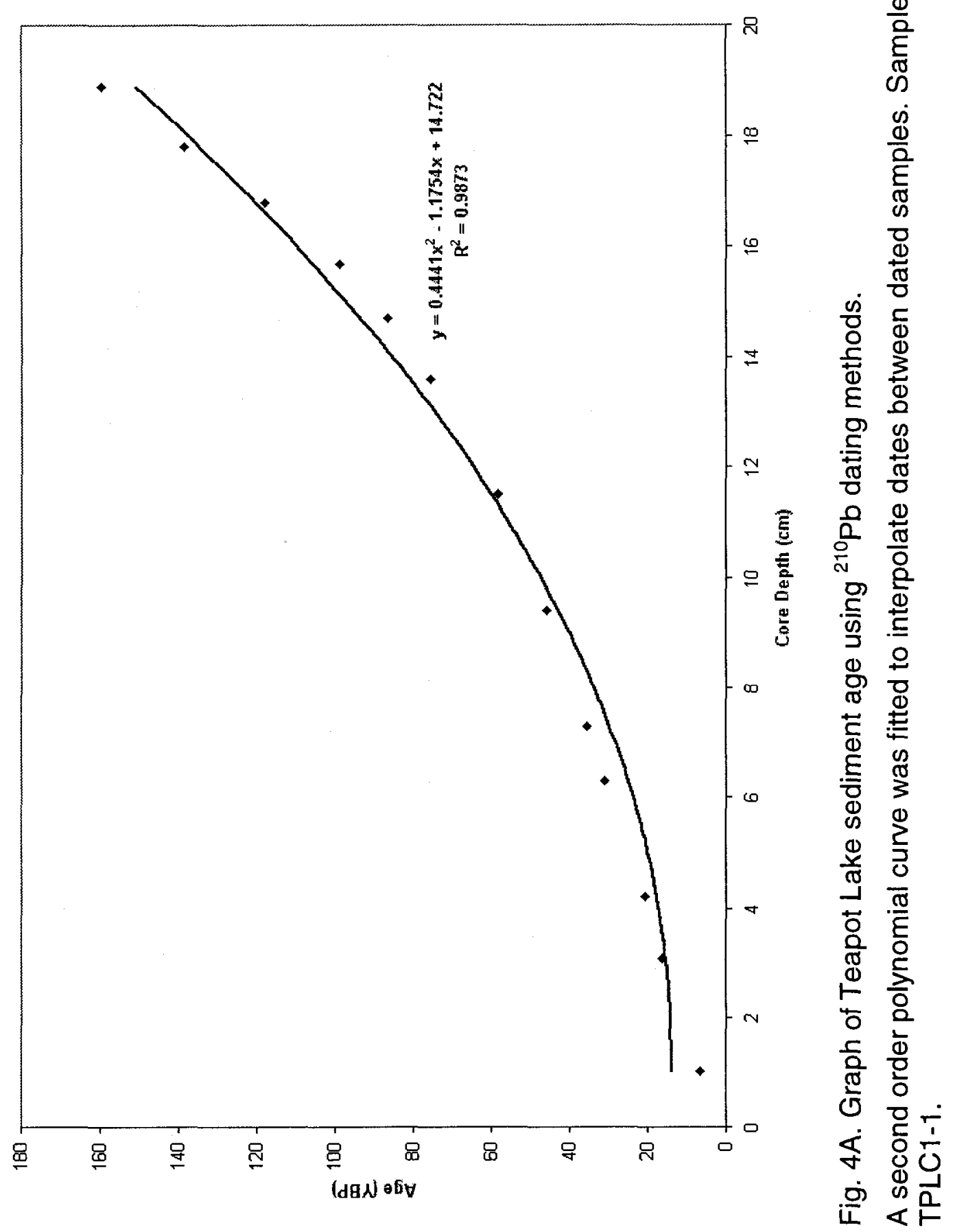




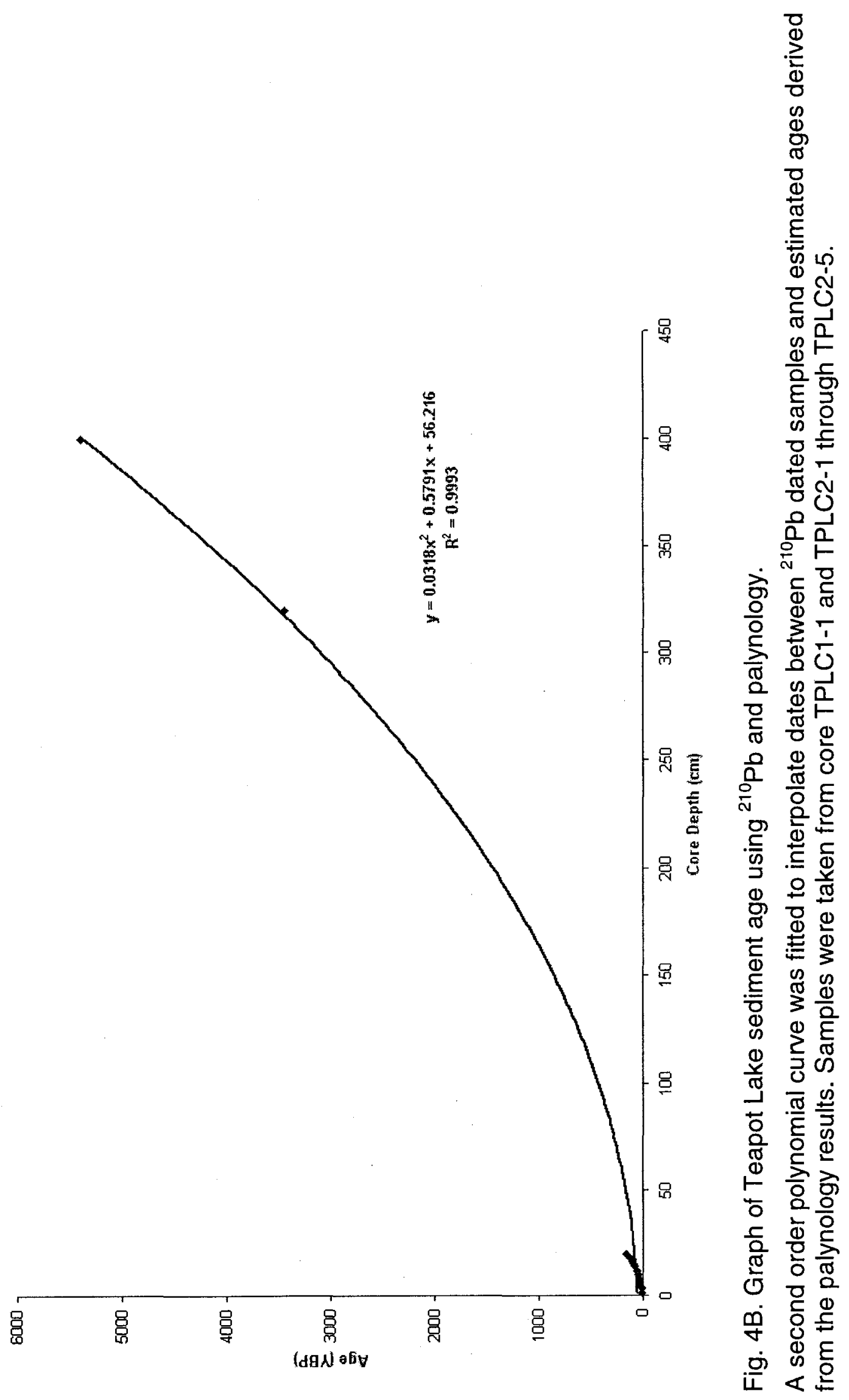




\section{Water Properties and Physical Characteristics of Teapot Lake}

Teapot Lake is very small in size relative to its depth $(12 \mathrm{~m})$, and is surrounded by thick forest cover, which impedes wind-driven water circulation, resulting in continuous stratification. Water property data measurements collected from Teapot Lake on August 17, 2005 (Table 2) indicated that the water was stratified with a distinct thermocline; the top $2.5 \mathrm{~m}$ being distinctly different from the rest of the water column. Between $2.5 \mathrm{~m}$ and $3.0 \mathrm{~m}$ depth, water temperature decreased by $4.4{ }^{\circ} \mathrm{C}$, and from $23.70^{\circ} \mathrm{C}$ at the surface to $9.85^{\circ} \mathrm{C}$ at $3.0 \mathrm{~m}$ depth. The water column temperature declined progressively beneath $3 \mathrm{~m}$ to $5.1^{\circ} \mathrm{C}$ at the lake bottom (12 m). Similarly, dissolved oxygen decreased from $18.2 \mathrm{mgL}^{-1}$ at $2 \mathrm{~m}$ water depth to $0.82 \mathrm{mgL}^{-1}$ by $3 \mathrm{~m}$ water depth. Dissolved oxygen content in the water progressively decreased from this horizon to the lake bottom where a value of $0.32 \mathrm{mgL}^{-1}$ was observed (Table 2). The water column in Teapot Lake was sampled again on April 13, 2006, when similar results and trends were observed.

Total phosphorus (TP) measurements indicated concentrations ranged from $0.19-0.20 \mathrm{mgL}^{-1}$ from $0.5-1.0 \mathrm{~m}$ depth in August 2005 (Table 3). Measurements taken the following spring indicated little change in TP, with a value of $0.22 \mathrm{mgL}^{-1}$ observed at $0.5 \mathrm{~m}$ water depth. TP concentrations were observed to increase with increasing water depth, with a value of $1.53 \mathrm{mgL}^{-1}$ measured at $9 \mathrm{~m}$ water depth. Similarly, concentrations of iron and manganese increased with increasing water depth (Table 3). 
Analysis of a 12-month temperature data logger record indicated the thermocline observed in Teapot Lake in August 2005 remained undisturbed year-round, with the exception of an 11-hour period. At each of $1 \mathrm{~m}, 3 \mathrm{~m}$, and $8 \mathrm{~m}$ water depths, where the temperature loggers were deployed, there were a total of 8064 temperature measurements recorded in Teapot Lake between April 15, 2006 and March 17, 2007. Mean recorded temperatures were $13.0 \pm 8.4{ }^{\circ} \mathrm{C}(1 \mathrm{~m}), 8.7 \pm 4.8$ ${ }^{\circ} \mathrm{C}(3 \mathrm{~m})$, and $4.4 \pm 0.3^{\circ} \mathrm{C}(8 \mathrm{~m})$. There was also a range in temperature of $26.8^{\circ} \mathrm{C}$ at $1 \mathrm{~m}$ depth, $13.6^{\circ} \mathrm{C}$ at $3 \mathrm{~m}$ depth, and only $1.1^{\circ} \mathrm{C}$ at $8 \mathrm{~m}$ water depth. There was an eleven-hour period, on December 2, 2006, when at all three water depths the same temperature $\left(4.9^{\circ} \mathrm{C}\right)$ was recorded. Measurements for the rest of the study period indicated that water temperatures were otherwise always different at these water depths (Fig. 5). There is also no evidence that any significant fall turnover occurred during the short interval in which the lake was the same temperature at $1 \mathrm{~m}, 3 \mathrm{~m}$, and $8 \mathrm{~m}$, as oxygen profiles measured in the lake before and after this date were always characterized by anoxic conditions at the lake bottom.

From the surface of the water, down to $3.75 \mathrm{~m}$ water depth, algae had grown on the chain holding the temperature data loggers in place during the 18-month period that it was submerged. Below that depth, there was no growth of any kind observed, a further indication of anoxic bottom waters. Algae had also grown on the top two data loggers ( $1 \mathrm{~m}$ and $3 \mathrm{~m}$ water depth), while a freshwater sponge had grown on the data logger located at $1 \mathrm{~m}$ depth. The data logger located at 8 
$\mathrm{m}$ water depth had no overgrowths whatsoever providing further qualitative evidence of the anoxic conditions existing at depth in Teapot Lake.

A sub-bottom profile of Teapot Lake (Fig. 6) indicated that the lake bottom in Teapot Lake is characterized by a series of abruptly dropping off terraced benches on all sides and at several depths (Fig. 6). These distinct features, which can be traced laterally around Teapot Lake suggest that the water body may have been characterized by several different water depths through its history, probably related to paleoclimate. The variation in the size and depth of Teapot Lake related to these changes could have had a significant impact on diatom community composition (Reavie and Smol 2001). Unfortunately, it is impossible to date these terraces with the available data so their possible relationship to observed diatom assemblage changes cannot be ascertained.

During a site visit on September 22, 2007, a number of very large bottom mats, varying in size, but measuring up to $80 \mathrm{~m}$ in length and $1 \mathrm{~m}$ in depth, appeared to have floated to the surface of the lake. They were composed of thick masses of moss, plant roots and gyttja, with Canada Goose (Branta canadensis) droppings and feathers noted on top of some of the mats. A Great Blue Heron (Ardea herodius) was also observed standing on the largest bottom mat for an extended period of time. These bottom mats were not present during other visits to Teapot Lake in August 2005, or in April 2006, and TRCA authority personnel had no recollection of ever seeing any at other times in the past (Don Ford, personal 
communication 2007). The mats may have been dislodged and floated to the surface as a result of explosives related seismic activity related to the massive new Highway 410 extension construction project occurring $<1 \mathrm{~km}$ to the northeast in 2007 . Confirmation of the unique nature of this event was provided by examination of cores taken at water depths beneath the thermocline where no vegetation is found. No evidence of previous floating mats is found at any horizon through these cores. In addition, the ${ }^{210} \mathrm{~Pb}$ chronology obtained was uninterrupted indicating that no allochthonous sediment was present in the upper $20 \mathrm{~cm}$ of the core. 
Table 2. Teapot Lake Water Property Profile, August 17, 2005.

(Hydrolab Surveyor 3)

\begin{tabular}{|c|c|c|c|c|c|c|}
\hline $\begin{array}{c}\text { Depth } \\
(\mathrm{m})\end{array}$ & $\begin{array}{c}\text { Temperature } \\
\left({ }^{\circ} \mathrm{C}\right)\end{array}$ & $\begin{array}{c}\text { Dissolved } \\
\text { Oxygen } \\
\left(\mathrm{mgL}^{-1}\right)\end{array}$ & $\begin{array}{c}\text { Conductance } \\
\left(\mu \mathrm{Scm}^{-1}\right)\end{array}$ & $\mathrm{pH}$ & Redox & $\begin{array}{c}\% \\
\text { Dissolved } \\
\text { Oxygen }\end{array}$ \\
\hline 0.5 & 23.70 & 6.82 & 320 & 8.23 & 578 & 83.5 \\
1.0 & 23.53 & 6.80 & 319 & 8.13 & 570 & 81.7 \\
1.5 & 22.12 & 9.92 & 332 & 7.88 & 578 & 116.7 \\
2.0 & 18.12 & 18.20 & 334 & 9.16 & 358 & 198.2 \\
2.5 & 14.29 & 1.29 & 345 & 7.32 & 535 & 13.7 \\
3.0 & 9.85 & 0.82 & 348 & 6.85 & 60 & 7.1 \\
3.5 & 7.24 & 0.70 & 347 & 6.68 & 32 & 5.7 \\
4.0 & 5.90 & 0.62 & 348 & 6.57 & -4 & 5.0 \\
4.5 & 4.92 & 0.53 & 354 & 6.47 & -39 & 4.1 \\
5.0 & 4.41 & 0.46 & 358 & 6.41 & -54 & 3.6 \\
5.5 & 4.15 & 0.39 & 368 & 6.30 & -64 & 2.9 \\
6.0 & 3.98 & 0.34 & 378 & 6.22 & -69 & 2.6 \\
6.5 & 3.95 & 0.31 & 387 & 6.15 & -70 & 2.4 \\
7.0 & 3.96 & 0.27 & 399 & 6.07 & -68 & 2.0 \\
7.5 & 4.04 & 0.26 & 440 & 5.96 & -65 & 2.0 \\
8.0 & 4.17 & 0.23 & 488 & 5.84 & -48 & 1.8 \\
8.5 & 4.30 & 0.20 & 535 & 5.76 & -53 & 1.6 \\
9.0 & 4.42 & 0.21 & 592 & 5.70 & -55 & 1.6 \\
9.5 & 4.60 & 0.19 & 680 & 5.63 & -55 & 1.5 \\
10.0 & 4.71 & 0.20 & 793 & 5.59 & -55 & 1.6 \\
10.5 & 4.89 & 0.35 & 946 & 5.56 & -63 & 2.9 \\
11.0 & 5.00 & 0.35 & 1132 & 5.56 & -55 & 2.8 \\
11.5 & 5.11 & 0.34 & 1241 & 5.56 & -61 & 2.7 \\
12.0 & 5.13 & 0.32 & 1237 & 5.57 & -52 & 2.7 \\
\hline
\end{tabular}

Table 3. Teapot Lake Water Property Values.

(Ottawa-Carleton Water Quality Laboratory)

\begin{tabular}{|c|c|c|c|c|c|c|}
\hline $\begin{array}{c}\text { Date } \\
\text { Collected }\end{array}$ & $\begin{array}{c}\text { Water } \\
\text { Depth }(\mathrm{m})\end{array}$ & $\begin{array}{c}\text { Conductivity } \\
(\mu \mathrm{S} / \mathrm{cm})\end{array}$ & $\begin{array}{c}\mathrm{TP} \\
\left(\mathrm{mgL}^{-1}\right)\end{array}$ & $\mathrm{pH}$ & $\begin{array}{c}\mathrm{Fe} \\
(\mathrm{mg} / \mathrm{L})\end{array}$ & $\begin{array}{c}\mathrm{Mn} \\
(\mathrm{mg} / \mathrm{L})\end{array}$ \\
\hline 17-Aug-05 & 0.5 & 310 & 0.020 & 7.8 & 0.020 & 0.0166 \\
14-Apr-06 & 0.5 & 270 & 0.022 & 7.63 & 0.077 & 0.046 \\
18-Aug-05 & 1.0 & 310 & 0.019 & 7.72 & 0.022 & 0.021 \\
17-Aug-05 & 5.0 & 350 & 0.060 & 7.17 & 0.630 & 0.460 \\
18-Aug-05 & 6.0 & 370 & 0.050 & 6.97 & 0.780 & 0.420 \\
18-Aug-05 & 9.0 & 500 & 1.53 & 6.92 & 4.90 & 0.670 \\
\hline
\end{tabular}




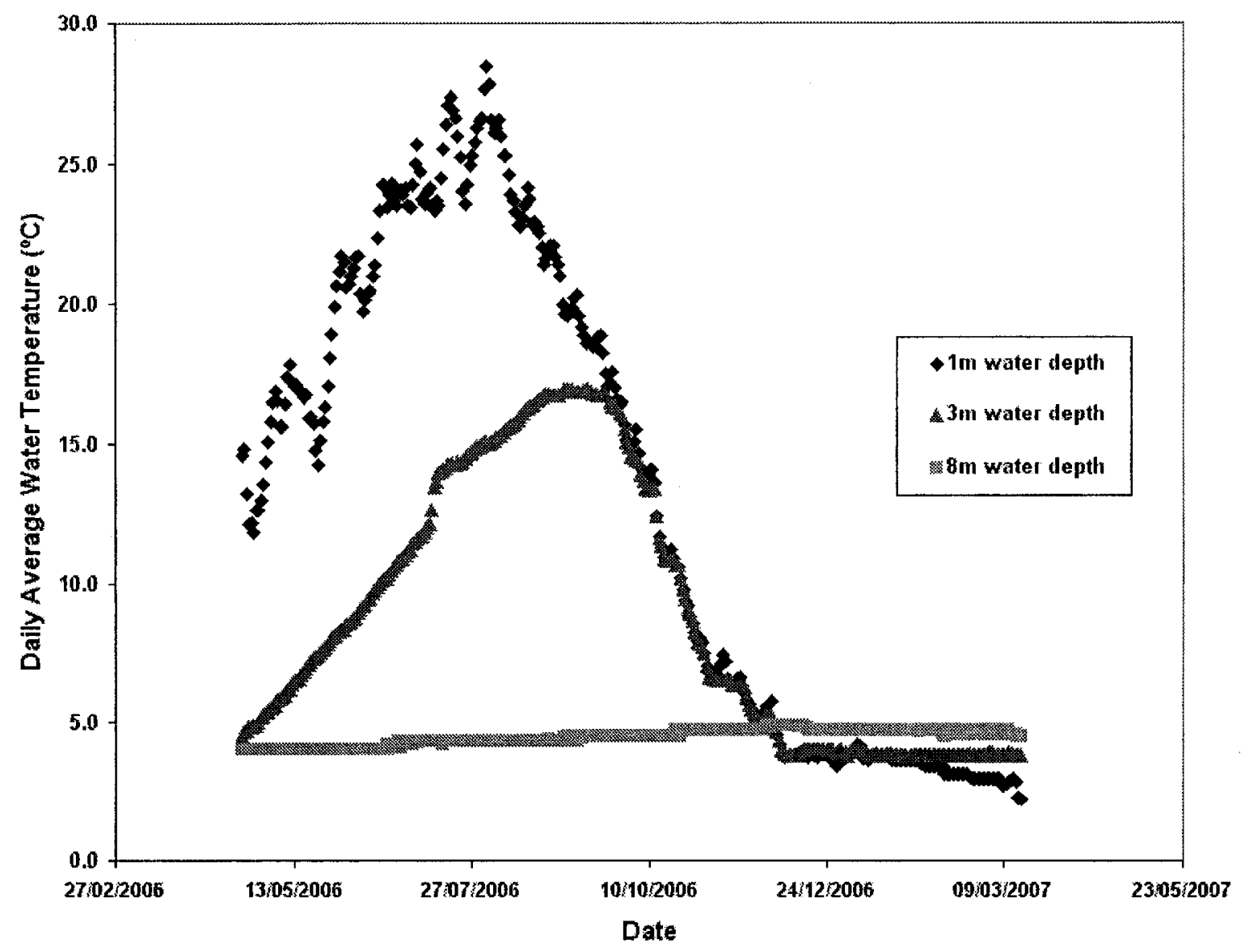

Fig. 5. Graph of Teapot Lake Water Temperatures from April 21, 2006 to March 16, 2007. 

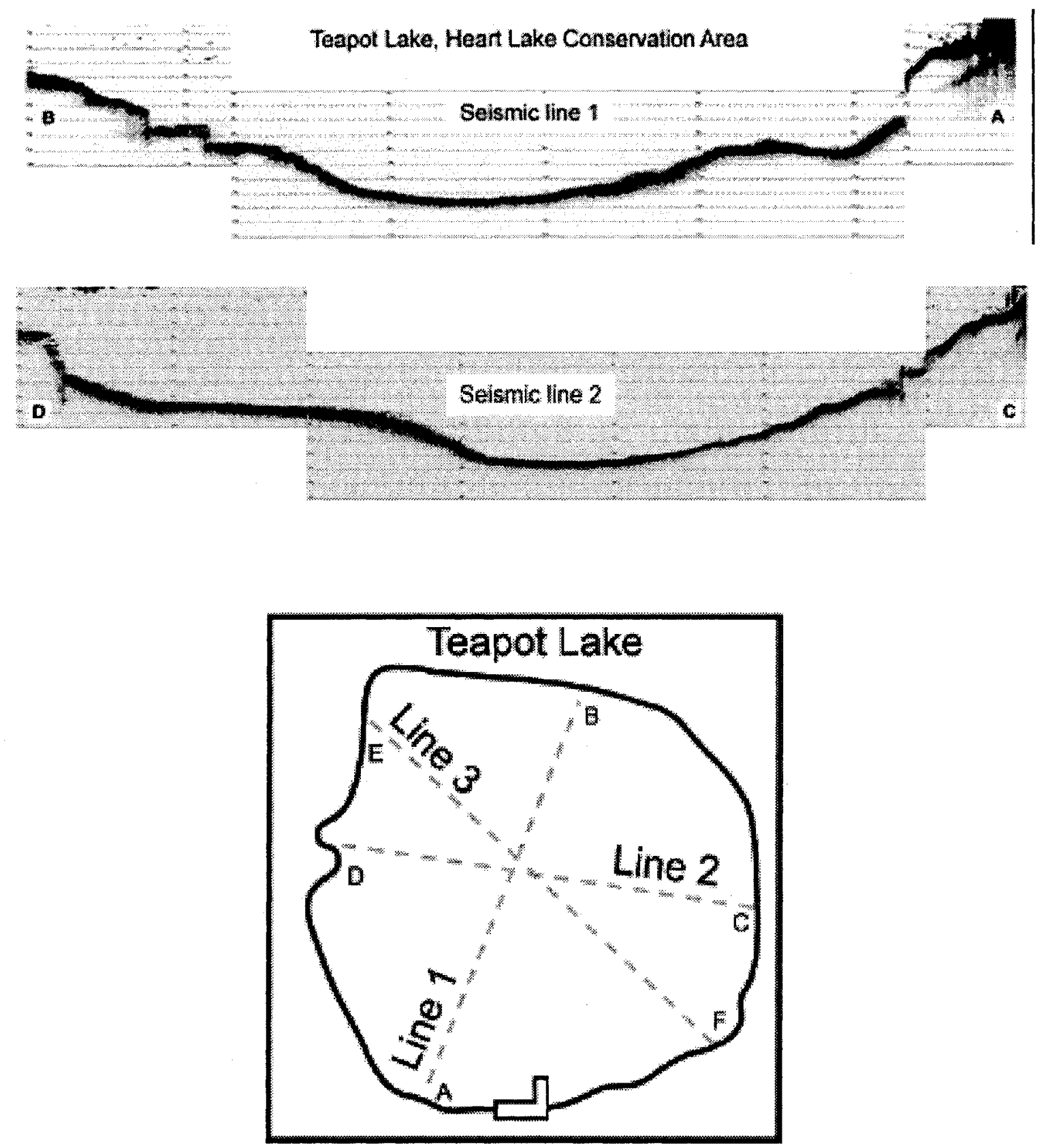

Fig. 6. Sub-bottom profiles of Teapot Lake, Ontario. 


\section{Fossil Diatom Assemblages}

One hundred and twenty-five taxa were identified from twenty-four genera in the Teapot Lake sediment core. Of these taxa, eighteen were present at $>5 \%$ abundance, in at least one sample, and thus deemed to be present in statistically significant number (Patterson and Fishbein 1989) (Fig. 7).

The results obtained for the stratigraphically lowermost sample analyzed, at 410 $\mathrm{cm}$ depth (ca. 5600 YBP), was significantly different from the rest of the samples examined, as indicated by cluster analysis of the diatom data (Fig. 8), and based on sedimentology (Fig. 2F). The most abundant species at this core depth was Fragilaria nanana Lange-Bertalot 1993 at $26 \%$ abundance, with Cyclotella comensis Grunow 1882 (20\% abundance), Fragilaria tenera Lange-Bertalot 1980 (15\% abundance), and Cyclotella michiganiana Skvortzow 1937 (13\% abundance) being the second, third and fourth most abundant species, respectively. Fragilaria nanana temporarily disappeared from the assemblage above this depth, however $C$. comensis, and $C$. michiganiana never reached $>1 \%$ of the assemblage in any of the other samples analyzed. 


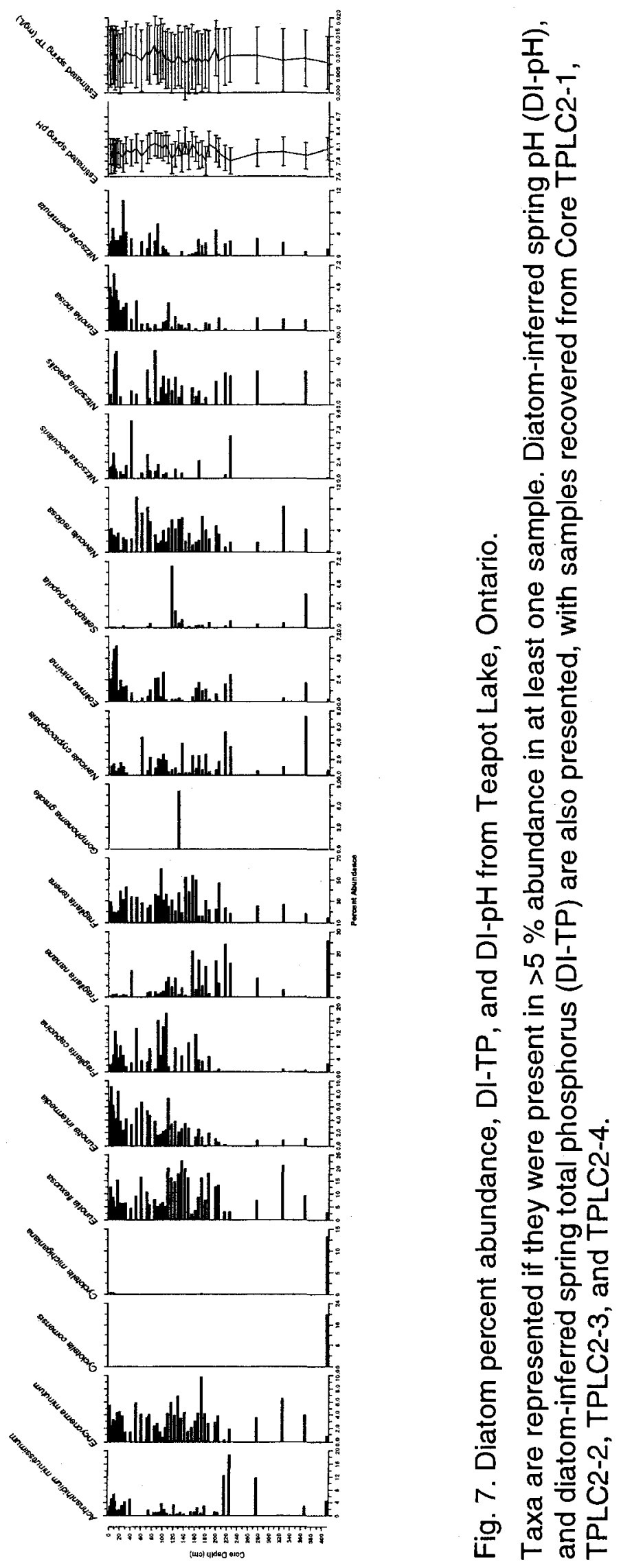


There were no drastic changes in diatom species assemblages observed in sediment samples from 368 to $40 \mathrm{~cm}$ core depth, and all samples clustered relatively closely. Throughout this interval, Fragilaria tenera comprised at least $14 \%$ of the assemblage, was never ranked lower than third in total abundance, and reached a peak abundance of $60 \%$ at $95 \mathrm{~cm}$ core depth. There were slight changes in species assemblages noted through this interval though, which were concomitant with changes in sedimentation patterns. From $260 \mathrm{~cm}$ to $200 \mathrm{~cm}$, there were no laminations observed, while distinct, fine laminations were observed through x-ray analysis from $200 \mathrm{~cm}$ to $100 \mathrm{~cm}$ sediment depth. At about $204 \mathrm{~cm}$ depth (ca. 510 A.D.), Achananthidium minutissimum (Kützing) Czarnecki 1994, which had varied from $12 \%$ to $19 \%$ abundance from $277 \mathrm{~cm}$ to $216 \mathrm{~cm}$ depth, decreased abruptly to only $1 \%$ abundance, and did not increase again to $>5 \%$ abundance until $40 \mathrm{~cm}$ depth. At this same interval, F. tenera doubled in abundance and Eunotia flexuosa (Brebisson in Kutzing) Kützing 1849, Eunotia intermedia (Krasske ex Hustedt) Nörpel \& Lange-Bertalot in LangeBertalot 1993, and Fragilaria capucina Desmazières 1925 all increased in abundance, and remained in the assemblage to the top of the core. A change in sedimentology was again noted at $100 \mathrm{~cm}$ depth (ca. 1575 A.D.), with no laminar pattern being observed from $100 \mathrm{~cm}$ depth to the top of the core. Just before the change in sedimentation pattern (at $105 \mathrm{~cm}$ sediment depth), E. flexuosa underwent a sharp decrease in abundance to $5 \%$ from a $>15 \%$ abundance in the $110-148 \mathrm{~cm}$ core interval. E. flexuosa did not increase to $>10 \%$ abundance again until the $70 \mathrm{~cm}$ core horizon. Similarly, at the $105 \mathrm{~cm}$ core depth, Fragilaria 
capucina increased to $18 \%$ abundance from a $<9 \%$ abundance in the $110-154$ $\mathrm{cm}$ core interval.

Cluster analysis of diatom percent abundance indicated that the top $30 \mathrm{~cm}$ of the core was distinctly different from the rest of the core (Fig. 8). Based on extrapolation using the polynomial equation calculated with the ${ }^{210} \mathrm{~Pb}$ data, this core interval encompassed the period from ca. A.D. 1620 to present. This section of the core was characterized by an abundance of $F$. tenera (ranging from $14 \%$ $43 \%$ abundance), with a notable spike in abundance ( $10 \%$ of the assemblage) of Nitzschia palea (Kützing) W. Smith 1856 at $25 \mathrm{~cm}$ depth, and an evenly distributed assemblage of Achnanthidium minutissimum, Encyonema minutum (Hilse) Mann in Round et al. 1990, Eunotia flexuosa, Eunotia intermedia, Fragilaria capucina, and Navicula radiosa Kützing 1844 comprising the rest of the assemblage in this interval.

\section{Diatom-inferred pH and Total Phosphorus (DI-pH and DI-TP)}

Diatom-inferred total phosphorus (DI-TP) for this core was subject to large error, and changes through time were not significant (Fig. 7). DI-TP ranged from $0.008-0.013 \mathrm{mgL}^{-1}$ while measured values from $0.5 \mathrm{~m}$ water depth ranged from $0.020-0.022 \mathrm{mgL}^{-1}$. DI-pH ranged from 7.8 to 8.2 (Fig. 7), indicating there was very little change inferred in the $\mathrm{pH}$ of Teapot Lake from ca. 5600 YBP to the present day. The calculated DI-pH of 8.0 determined for $1 \mathrm{~cm}$ sediment depth closely corresponds with water chemistry measurements taken in August 2005, and in April 2006, which provided a pH value of $7.63-7.8$ for the lake - bottom sediment -water interface. 


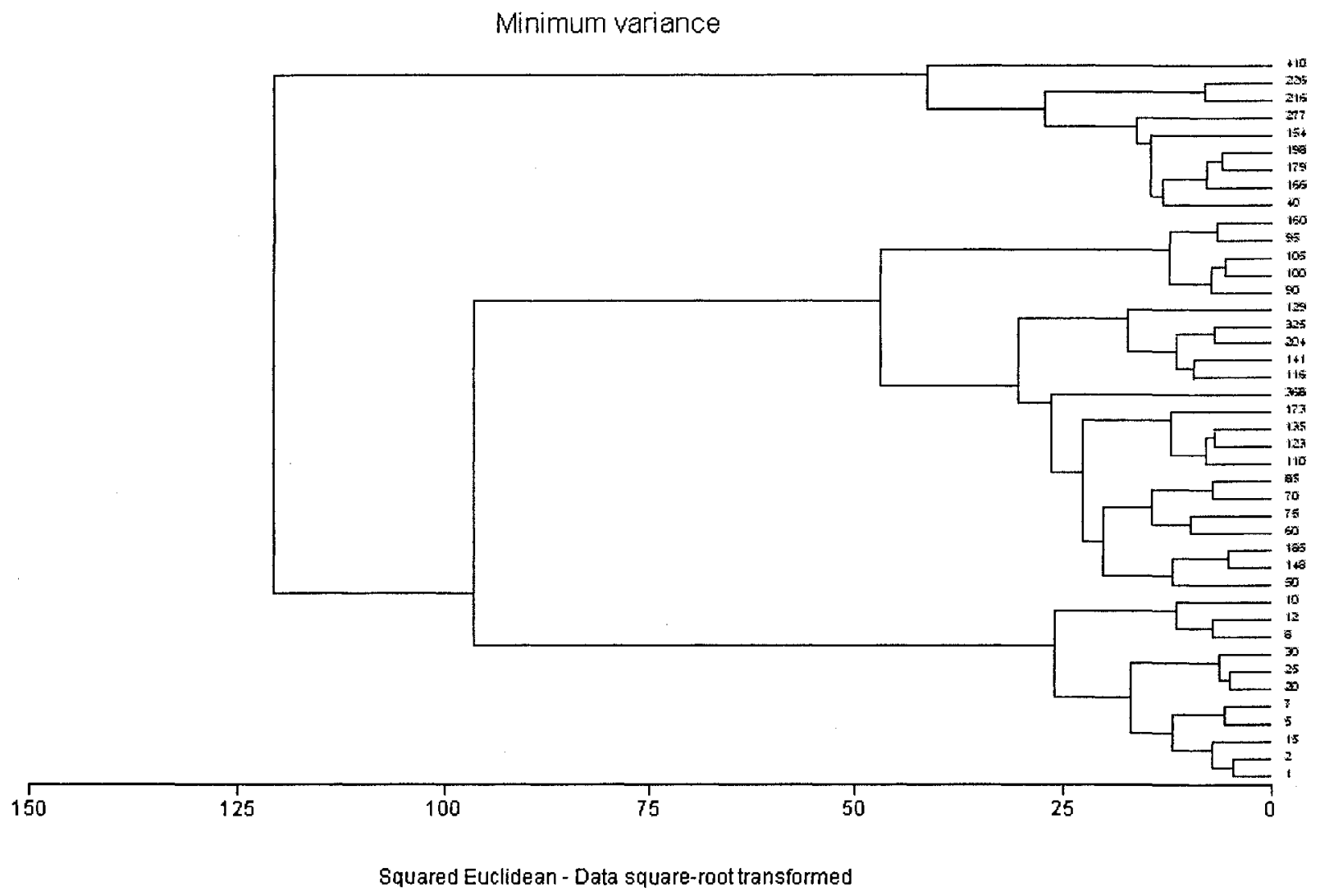

Fig. 8. Cluster analysis of diatom species percent abundance from Teapot Lake, Ontario.

The numbers on the right side indicate the core depth (in $\mathrm{cm}$ ) of the samples analyzed. Samples were recovered from Core TPLC2-1, TPLC2-2, TPLC2-3, and TPLC2-4. 


\section{Discussion}

The results of the temperature logger study indicate there is a distinctive thermocline and chemocline in Teapot Lake, and that there is no vertical mixing of the water column through the year. The lake is therefore meromictic (Cohen 2003; McNeely 1973), despite the lack of laminated sediments in the upper portion of the core. Diatom assemblages recovered from downcore should therefore provide a high-resolution paleolimnological record of conditions in the lake (Cohen 2003; Hall and Smol, 1999; Reavie and Smol, 2001).

Cluster analysis of the diatom data indicated that the sample from $410 \mathrm{~cm}$ core depth is significantly different from the flora recovered from any other samples collected up core. Palynological evidence of a disturbance in the terrestrial ecosystem is observed just above this core depth, at $400 \mathrm{~cm}$ depth, as indicated by the rapid decline of Tsuga canadensis (Eastern Hemlock), a decline in Picea (Spruce), and an increase in abundance of the successional species Fagus (Beech). The change in Eastern Hemlock abundance in this region has previously been dated at ca. 5400 YBP (Bennett and Fuller 2002; Chalcote 2003; Fuller 1998; Davis 1981) and may be related to an insect outbreak (Allison et al. 1986; Bhiry and Filion 1996) linked to warming during the hypsithermal warm period in the present-day Brampton area (Edwards and Fritz 1986) and elsewhere (Lamb 1977). Other studies show that this change to the regional forest ecosystem also had a significant impact in many Ontario lake ecosystems (e.g. Little Round Lake, Sunfish Lake, MacKay Lake, Flower Round Lake, Long 
Lake, Singleton Lake, and van Nostrand Lake; Boucherle et al. 1986; Hall and Smol 1993; St. Jacques et al. 2000). A peak in estimated hypsithermal DI-TP values in van Nostrand, Long and Singleton Lakes provide indirect evidence of this eutrophication (Hall and Smol 1993; St. Jacques et al. 2000). There is no corresponding peak in DI-TP dating from sediments deposited during the hypsithermal in Teapot Lake, although the inference is subject to large error. There is however, an associated diatom floral response observed in Teapot Lake as indicated by the presence of the meso-eutrophic planktonic species Cyclotella michiganiana (Ekdahl et al. 2007), and Cyclotella comensis which, together, comprised $>33 \%$ of the assemblage at $410 \mathrm{~cm}$ sediment depth. Above $410 \mathrm{~cm}$ depth, neither of these two species were present in the assemblage above $1 \%$ abundance in any other sample.

Frequent changes in sediment bedding orientation observed through $x$-ray analysis from $350 \mathrm{~cm}-315 \mathrm{~cm}$ are indicative of the adjustments to sedimentary inputs that the lake underwent through this time period. The pollen data indicates the return of Eastern Hemlock to the area at $325 \mathrm{~cm}$, which has been observed elsewhere in the region to occur at ca. 3450 YBP (Fuller 1998). The increased abundance of the diatom taxa Navicula radiosa, and Eunotia flexuosa indicate that nutrient conditions were changing (Enache and Prairie 2002) through this interval. 
The next notable change in the diatom species assemblage occurred at $204 \mathrm{~cm}$ sediment depth (ca. A.D. 510) and is accompanied by another change in sedimentology. Achananthidium minutissimum, an epiphytic species that can tolerate a broad range of nutrient and disturbance conditions (Beaver 1981; Potapova and Hamilton 2008), decreased abruptly in relative abundance at this horizon, and did not reappear in the assemblage to any great degree until $40 \mathrm{~cm}$ sediment depth. Also at $204 \mathrm{~cm}$ depth, the tychoplanktonic taxa Fragilaria tenera doubled in abundance and other taxa such as Eunotia flexuosa, Eunotia intermedia, and Fragilaria capucina also increased in abundance, an indication that there was a change in nutrient conditions in the lake. The palynological results indicate that there were changes occurring in the landscape that could have affected lake water, with increases in Picea observed at $214 \mathrm{~cm}$ sediment depth, while abundance of Tsuga canadensis remained low.

At $105 \mathrm{~cm}$ depth (ca. A.D. 1540) there is another change in the diatom assemblage, again accompanied by a change in sedimentology, which correlates with a spike in abundance of microscopic charcoal. Eunotia flexuosa underwent a sharp decrease in abundance to $5 \%$ and did not increase to $>10 \%$ abundance again until the $70 \mathrm{~cm}$ core horizon. Fragilaria capucina also increased in abundance at $105 \mathrm{~cm}$ providing a further indication of a disturbance to the ecosystem. Although the changes in sedimentology and observed levels of microscopic charcoal correlated with changes in the diatom species assemblages, the changes are not significant enough to impact either the 
inferred DI-TP or DI-pH, suggesting that the lake was largely sheltered from terrestrial influences during this period. These changes could be related to natural forest fires or even possible induced fire disturbance resulting from Iroquoian habitation (ca A.D. 500-1500) in the region (Warrick 2000). However, the changes to the Teapot Lake ecosystem through this interval are minor compared to the more considerable changes observed in other Ontario lake ecosystems (e.g. Crawford Lake, Swan Lake, and Wilcox Lake), which have been linked with Iroquoian land clearance for agriculture and housing (Ekdahl et al. 2007, Patterson et. al. 2002; Warrick 2000).

The top $30 \mathrm{~cm}$ of sediment collected from Teapot Lake are deposited from ca. A.D. 1620 to the present. Cluster analysis of the diatom percent abundance data indicate these samples are the most similar compared with the other samples (Fig. 8). Fragilaria tenera is the most abundant diatom through this section of the core, and Nitzschia palea reached its peak abundance in the core, at $25 \mathrm{~cm}$ core depth. There were no other major changes in the floral assemblage noted through this section, nor were there significant inferred changes in $\mathrm{DI}-\mathrm{pH}$ or DITP documented.

Results of previous studies from other lakes in the region (e.g. Swan Lake, Crawford Lake, Little Round Lake, Grignac Lake, and Second Lake) have been characterized by significant changes in diatom assemblages that provide a clear correlation with deforestation associated with European settlement and 
agriculture (beginning ca. A.D.1850), as well as more recent increases in population growth (ca. A.D.1965 to present) (Burden et al. 1986; Ekdahl et al. 2007; Patterson et al. 2002; Watchorn et al. 2008). In Teapot Lake, recognition of this signal associated with settlement related land use changes is not evident from either the observed diatom assemblages or the inferred DI-TP or DI-pH values. As Teapot Lake is meromictic, and not subject to bioturbation related "assemblage averaging" as would have occurred in the other studied lakes, the sedimentary record should provide a complete, undisturbed historic record of the lake, with sharp changes in diatom assemblages occurring when anthropogenic land use change occurred. As such assemblage changes are not noted in Teapot Lake, the lake must have been somehow protected from the impact of land use change in the area, or this lake has other properties that compensate for these anthropogenic effects.

A possible clue for the lack of evidence of recognizable anthropogenic influence may be related to the unique water chemistry of Teapot Lake. Concentrations of TP, iron and manganese all increase with increasing water depth (Table 3). In lakes with high concentrations of $\mathrm{Fe}$ and $\mathrm{Mn}$, which is the case with Teapot Lake, phosphorus sorbs with the Fe or Mn (Cohen 2003) and is deposited as vivianite or other iron or manganese phosphates on the lake bottom (Gammon, personal communication 2007). Since Teapot Lake is meromictic, the phosphorus deposited as vivianite at the bottom of the lake does not circulate to the upper part of the water column, and is therefore unavailable for diatom growth. 


\section{Conclusions}

Teapot Lake is a meromictic lake, which should contain an accurate sediment record due to lack of bioturbation. Analysis of diatom and pollen assemblages extracted from a sediment core dated from ca. 5600 YBP to present indicated there were minor adjustments in the aquatic ecosystem associated with disturbances to the landscape. The first disturbance was observed with a unique diatom assemblage from sediments dated at ca. 5600 YBP when Eastern Hemlock nearly disappeared due to an insect outbreak brought on by the hypsithermal warm period. Changes in sedimentology, and diatom assemblage, as well as increases in microscopic charcoal were observed in sediments dated from the period ca. A.D. 500 to 1500 which could be related to natural forest fires or to Iroquoian land clearance for agriculture and housing, although much more significant impacts have been observed in other lakes. The top $30 \mathrm{~cm}$ of the sediment core (ca. 1620 A.D. to present) grouped together in cluster analysis, and there should have been significant changes in diatom assemblage, DI-TP, $\mathrm{DI}-\mathrm{pH}$ and palynology through this section given the fact that European settlers moved into the area en masse during this period. However, this was not the case, and other changes observed indicated there was no significant correlation between diatom paleo-assemblages, or in diatom-inferred total phosphorus or $\mathrm{pH}$ that can be related to anthropogenic changes to the landscape. The most likely explanation is related to the unique geochemistry of the lake. Phosphorus entering the system, natural or anthropogenically produced, sorbs to $\mathrm{Fe}$ and $\mathrm{Mn}$, which are present at very high concentrations, to form vivianite and various other minerals that are deposited and thus sequestered on the lake bottom due to the 
meromictic nature of Teapot Lake. Thus, there is no paleolimnological evidence of the eutrophism, using diatoms as the biological proxy, associated with $19^{\text {th }}$ century land clearance and settlement, which characterizes all other examined lakes in the area. 


\section{References}

Allison TD, Moeller RE, Davis MB (1986) Pollen in laminated sediments provides evidence for a mid-Holocene forest pathogen outbreak. Ecology 67: 11011105.

Anderson NJ (1995) Using the past to predict the future: lake sediments and the modelling of limnological disturbance. Ecol Model 78: 149-172.

Appleby PG, Nolan PJ, Gifford DW, Godfrey MJ, Oldfield F, Anderson NJ, Battarbee RW $(1986){ }^{210} \mathrm{~Pb}$ dating by low background gamma counting. Hydrobiologia 143: 21-27.

Appleby PG, Oldfield F (1978) The calculation of lead-210 dates assuming a constant rate of supply of unsupported ${ }^{210} \mathrm{~Pb}$ to the sediment. Catena 5: 18.

Bennett KD, Fuller JL (2002) Determining the age of the mid-Holocene Tsuga canadensis (hemlock) decline, eastern North America. The Holocene 12: 421-429.

Beaver J (1981) Apparent ecological characteristics of some common freshwater diatoms. Ontario Ministry of the Environment. Don Mills, Ontario, $513 \mathrm{pp}$.

Benninghoff WS (1962) Calculation of pollen and spore density in sediments by addition of exotic pollen in known quantities. Pollen et Spores 4: 332-333.

Bhiry N, Filion L (1996) Mid-Holocene Hemlock Decline in Eastern North America linked with phytophagous insect activity. Quat Res 45: 312-320.

Binford MW (1990) Calculation and uncertainty analysis of ${ }^{210} \mathrm{~Pb}$ dates for PIRLA project lake sediment cores. J Paleolimnol 3: 253-267.

Boucherle MM, Smol JP, Oliver TC, Brown SR, McNeely R (1986) Limnological consequences of the decline in hemlock 4800 years ago in three Southern Ontario lakes. Hydrobiologia 143: 217-225.

Burden ET, McAndrews JH, Norris G (1986) Palynology of Indian and European forest clearance and farming in lake sediment cores from Awenda Provincial Park, Ontario. Can J Earth Sci 23: 43-54.

Calcote, R (2003) Mid-Holocene climate and the hemlock decline: the range limit of Tsuga Canadensis in the western Great Lakes regions, USA. The Holocene 13: 215-224. 
Canniff W (1869) History of the Settlement of Upper Canada, (Ontario) with Special Reference to The Bay of Quinte. Dudley and Burns, Printers, Victoria Hall, Toronto, $666 \mathrm{pp}$.

Chapman LJ, Putnam DF (1966) The physiography of southern Ontario. University of Toronto Press, Toronto, $386 \mathrm{pp}$.

Cohen AS (2003) Paleolimnology: The History of the Evolution of Lake Systems. Oxford University Press, New York, 398 pp.

Davis MB (1981) Outbreaks of forest pathogens in Quaternary history. Proceedings of the IV International Palynology Conference, Lucknow, (1976-1977) 3: 216-227.

Deevey ESJ (1965) Sampling Lake Sediments by use of the Livingstone Sampler. In: Kummel B, Raup D (eds) Handbook of Paleontological Techniques. W.H. Freeman and Company, San Francisco and London.

DMTI Spatial Inc (2003) Esri Data and Maps. Canada Water Bodies. Redlands California, USA.

Edwards TWD, Fritz $P$ (1986) Assessing meteoric water composition and relative humidity from ${ }^{18} \mathrm{O}$ and ${ }^{2} \mathrm{H}$ in wood cellulose: paleoclimatic implications for southern Ontario, Canada. Applied Geochemistry 1: 712-723.

Ekdahl EJ, Teranes JL, Wittkop CA, Stoermer EF, Reavie ED, Smol JP (2007) Diatom assemblage response to Iroquoian and Euro-Canadian eutrophication of Crawford Lake, Ontario, Canada. J Paleolimnol 37: 233246.

Enache M, Prairie YT (2002) WA-PLS diatom-based pH, TP and DOC inference models from 42 lakes in the Abitibi clay belt area (Quebec, Canada) $\mathrm{J}$ Paleolimnol 27: 151-171.

Fægri K, Iversen J (1989) Textbook of Pollen Analysis, fourth ed. The Blackburn Press: New Jersey, 328 pp.

Fuller JL (1998) Ecological impact of the mid-Holocene hemlock decline in southern Ontario, Canada. Ecology 79: 2337-2351.

Gordon AD, Birks HJB (1972) Numerical methods in Quaternary palaeoecology. New Phytol 71: 961-979.

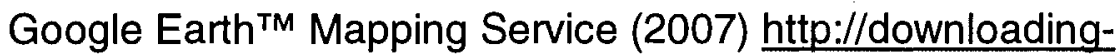
now.com/googleearth/1/ Cited 20 March 2008. 
Grimm EC (1987) CONISS: a FORTRAN 77 program for stratigraphically constrained cluster analysis by the method of incremental sum of squares. Computers and Geoscience 13: 13-35.

Grimm EC (1993) TILIA v2.0 Illinois State Museum, Research and Collections Center, Springfield.

Hall RI, Smol JP (1999) Diatoms as indicators of lake eutrophication. In: Stoermer EF, Smol JP (eds) The Diatoms: Applications for the Environmental and Earth Sciences. Cambridge University Press, Cambridge, pp. 128-159.

Hall RI, Smol JP (1996) Paleolimnological assessment of long-term water-quality changes in south-central Ontario lakes affected by cottage development and acidification. Can J Fish Aquat Sci 53: 1-17.

Hall RI, Smol JP (1993) The influence of catchment size on lake trophic status during the hemlock decline and recovery (4800-3500 BP) in southern Ontario Lakes. Hydrobiologia 269/270: 370-390.

Juggins S (2005) C2 Version 1.5: Software for ecological and paleoecological data analysis and visualization.

http://www.campus.ncl.ac.uk/staff/Stephen.Juggins/software/C2Home.htm Cited 14 January 2008.

Kapp RO, Davis OK, King JE (2000) Pollen and Spores, second ed. The American Association of Stratigraphic Palynologists: College Station, 279 pp.

Karrow PF, Harrison W, Saunderson HC (1977) Reworked Middle Wisconsinan (?) plant fossils from the Brampton esker, southern Ontario. Can J Earth Sci 14: 426-430.

Krammer K (2003) Diatoms of Europe: Diatoms of the European Inland Waters and Comparable Habitats.vol 4 Cymopleura, Delicata, Navicymbula, Gomphocymbellopsis, Afrocymbella, (ed) Horst Lange-Bertalot. A.R.G. Gantner Verlag K.G. Germany, 530 pp.

Krammer K (2002) Diatoms of Europe: Diatoms of the European Inland Waters and Comparable Habitats.vol 3 Cymbella (ed) Horst Lange-Bertalot.

A.R.G. Gantner Verlag K.G. Germany, 584 pp.

Krammer K (2000) Diatoms of Europe: Diatoms of the European Inland Waters and Comparable Habitats.vol 1 The genus Pinnularia, (ed) Horst LangeBertalot. A.R.G. Gantner Verlag K.G. Germany, 703 pp. 
Krammer K (1997a) Die Cymbelloiden Diatomeen: Eine Monographie der wetweit bekannten Taxa Teil 1. Allgemeines und Encyonema Part. J. Cramer. Stuttgart, Germany, $382 \mathrm{pp}$.

Krammer K (1997b) Die cymbelloiden Diatomeen Eine Monographie der weltweit bekanten Taxa Teil 2. Encyonema part., Encyonopsis and Cymbellopsis. J. Cramer. Stuttgart, Germany, $469 \mathrm{pp}$.

Krammer K, Lange-Bertalot H (1986) Bacillariophyceae Süßwasserflora von Mitteleuropa, 2/1. Teil: Naviculaceae. Gustav Fischer Verlag Stuttgart, New York, 876 pp.

Krammer K, Lange-Bertalot H (1988) Bacillariophyceae Süßwasserflora von Mitteleuropa, 2/2. Teil: Bacillariaceae, Epithemiaceae, Surirellaceae. Gustav Fischer Verlag Stuttgart, New York, 596 pp.

Krammer K, Lange-Bertalot $\mathrm{H}$ (1991a) Bacillariophyceae Süßwasserflora von Mitteleuropa, 2/3. Teil: Centrales, Fragilariaceae, Eunotiaceae. Gustav Fischer Verlag Stuttgart, New York, 576 pp.

Krammer K, Lange-Bertalot H (1991b) Bacillariophyceae Süßwasserflora von Mitteleuropa, 2/4. Teil: Achnanthaceae, Kritische Ergänzungen Zu Navicula (Lineolatae) und Gomphonema Gesamtliteraturverzeichnis Teil 1-4. Gustav Fischer Verlag Stuttgart, New York, 437 pp.

Lamb HH (1977) Climatic History and the Future. Methuen \& Co. Ltd., London, $711 \mathrm{pp}$.

Lange-Bertalot $\mathrm{H}$ (2001) Diatoms of Europe: Diatoms of the European Inland Waters and Comparable Habitats.vol 2 Navicula sensu stricto, 10 Genera Separated from Navicula sensu lato, Frustulia, (ed) Horst Lange-Bertalot. A.R.G. Gantner Verlag K.G. Germany, 526 pp.

McNeely R (1973) Limnological investigations of a small meromictic lake, Little Round Lake, Ontario, unpublished PhD dissertation, Queen's University, Ontario, $196 \mathrm{pp}$.

Motz JE, Morgan AV (2001) Holocene paleoclimate and paleoecology determined from fossil Coleoptera at Brampton, Ontario, Canada. Can J Earth Sci 38: 1451-1462.

Natural Resources Canada (2002) GeoBase Geopolitical boundaries - Level 1. Ottawa, Ontario, Canada. 
Pappas JL, Stoermer EF (1996) Quantitative methods for determining a representative algal count. J Phycol 32: 693-696.

Patrick R, Reimer CW (1966) The diatoms of the United States Exclusive of Hawaii. Vol. 1. Fragilariaceae, Eunotiaceae, Achnanthaceae, Naviculaceae. The Academy of Natural Sciences of Philadelphia. USA, $688 \mathrm{pp}$.

Patterson RT, Dalby A, Kumar A, Henderson LA, Boudreau REA (2002) Arcellaceans (thecamoebians) as indicators of land-use change: settlement history of the Swan Lake area, Ontario as a case study. J Paleolimnol 28: 297-316.

Patterson RT, Fishbein E (1989) Re-examination of the statistical methods used to determine the number of point counts needed for micropaleontological quantitative research. J Paleontol 63: 245-248.

Potapova M, Hamilton PB (2007) Morphological and ecological variation within the Achnanthidium minutissimum (Bacillariophyceae) species complex. J Phycol 43: 561-575.

Reavie ED, Smol JP (2001) Diatom-environmental relationships in 64 alkaline southeastern Ontario (Canada) lakes: a diatom-based model for water quality reconstructions. J Paleolimnol 25: 25-42.

Siver PA, Kling H (1997) Morphological observations of Aulocoseira using scanning electron microscopy. Can J Bot 75: 1807-1835.

Statistics Canada (2007) Population and dwelling counts, for Canada, census metropolitan areas census agglomerations and census subdivisions (municipalities), 2006 and 2001 censuses. http://www12.statcan.ca/english/census06/data/popdwell/Table.cfm?T=20 5\&RPP $=50$. Cited 13 January 2008.

Statistics Canada (2001) Province of Ontario Data Spatial Files. Statistical Reference Centre. (National Capital Region), Ottawa, Ontario, Canada.

St. Jacques J-M, Douglas MS, McAndrews JH (2000) Mid-Holocene hemlock decline and diatom communites in van Nostrand Lake, Ontario, Canada. J Paleolimnol 23: 385-397.

Stockmarr J (1971) Tablets with spores used in absolute pollen analysis. Pollen et Spores 13: 615-621. 
TRCA (1998) Toronto and Region Conservation Authority. State of the Watershed Report: Etobicoke and Mimico Creek Watershed Reports. http://www.trca.on.ca/water_protection/strategies/etobicoke/pdf/EMcwshe d98.pdfPp. 53, 76. Cited 20 January 2006.

Warrick G (2000) The Precontact Iroquoian Occupation of Southern Ontario. Journal of World Prehistory 14: 415-466.

Watchorn MA, Hamilton PB, Anderson TW, Roe HM, Patterson RT (2008) Diatoms and pollen as indicators of water quality and land use change: a case study from the Oak Ridges Moraine, Southern Ontario, Canada. J Paleolimnol 39: 491-509. 


\section{Appendix 1. Diatom percent abundance data: Haynes Lake, Ontario}

\begin{tabular}{|c|c|c|c|c|c|c|c|}
\hline \multicolumn{8}{|c|}{ Diatom percent abundance: Haynes Lake, Ontario } \\
\hline \multirow[t]{2}{*}{ Taxon } & \multicolumn{7}{|c|}{ Core Depth } \\
\hline & $1 \mathrm{~cm}$ & $5 \mathrm{~cm}$ & $11 \mathrm{~cm}$ & $15 \mathrm{~cm}$ & $20 \mathrm{~cm}$ & $25 \mathrm{~cm}$ & $30 \mathrm{~cm}$ \\
\hline Ach. lanc. lanceolata & 0.576 & 0.000 & 0.000 & 0.143 & 0.000 & 0.000 & 0.000 \\
\hline A. minutissimum total & 4.317 & 22.760 & 6.892 & 12.751 & 7.532 & 2.718 & 5.894 \\
\hline Amphora capulata & 0.000 & 0.000 & 0.000 & 0.000 & 0.000 & 0.000 & 0.000 \\
\hline Brachysira brebissonii & 0.000 & 0.000 & 0.000 & 0.000 & 0.000 & 0.143 & 0.000 \\
\hline Asterionella formosa & 14.532 & 0.000 & 0.000 & 0.287 & 0.000 & 0.000 & 0.000 \\
\hline Cymb. amphicephala & 0.144 & 0.000 & 0.000 & 0.000 & 0.000 & 0.000 & 0.000 \\
\hline Cymbella cesatii & 0.000 & 0.000 & 0.000 & 0.000 & 0.000 & 0.000 & 0.999 \\
\hline Cymbella subcistula & 0.000 & 0.179 & 0.363 & 0.000 & 0.000 & 0.000 & 1.299 \\
\hline Cymbella falaisensis & 0.000 & 0.000 & 0.000 & 0.000 & 0.000 & 0.000 & 0.500 \\
\hline Encyonema minuta & 0.288 & 0.179 & 0.363 & 0.000 & 0.000 & 0.572 & 0.699 \\
\hline Encyonema silesiacum & 0.000 & 0.000 & 0.000 & 0.000 & 0.000 & 0.000 & 0.200 \\
\hline Cocconeis euglyta & 0.000 & 0.000 & 0.000 & 0.000 & 0.000 & 0.000 & 0.000 \\
\hline Cyclotella bodanica & 1.151 & 0.000 & 0.605 & 0.000 & 0.000 & 0.000 & 0.000 \\
\hline Cycotella comensis & 1.727 & 0.000 & 0.000 & 0.000 & 0.000 & 0.000 & 0.100 \\
\hline Cyclo. michiganiana & 16.691 & 10.753 & 43.047 & 3.725 & 12.597 & 6.724 & 6.194 \\
\hline Cyclotella stelligera & 15.827 & 26.344 & 22.128 & 40.688 & 60.390 & 71.388 & 72.927 \\
\hline Eunotia praerupta & 0.000 & 0.000 & 0.000 & 0.000 & 0.000 & 0.000 & 0.300 \\
\hline Fragilaria biceps & 0.000 & 0.000 & 0.000 & 0.000 & 0.000 & 0.000 & 0.000 \\
\hline Fragilaria brevistriata & 0.000 & 0.000 & 0.000 & 0.000 & 0.000 & 0.000 & 0.000 \\
\hline Fragilaria cap. v. gracilis & 0.576 & 0.000 & 0.121 & 0.000 & 0.000 & 0.286 & 0.500 \\
\hline Staurosira construens & 0.144 & 0.179 & 0.000 & 0.000 & 0.000 & 0.000 & 0.000 \\
\hline Fragilaria cyclopum & 0.000 & 1.075 & 0.000 & 0.573 & 0.000 & 0.143 & 0.200 \\
\hline Frag. delicatissima & 2.446 & 3.047 & 1.451 & 5.874 & 2.597 & 1.574 & 1.099 \\
\hline Fragilaria leptostauron & 0.000 & 0.000 & 0.000 & 0.000 & 0.000 & 0.000 & 0.000 \\
\hline F. nanana Total & 3.453 & 4.659 & 3.990 & 16.046 & 7.662 & 6.724 & 4.396 \\
\hline Fragilaria pinnata & 0.863 & 0.358 & 0.605 & 0.000 & 0.130 & 0.000 & 0.000 \\
\hline Fragilaria tenera & 0.000 & 0.000 & 0.000 & 0.000 & 0.000 & 0.286 & 0.100 \\
\hline Gomp. acuminatum & 0.000 & 0.000 & 0.242 & 0.000 & 0.000 & 0.000 & 0.100 \\
\hline Gomp angustatum & 0.000 & 0.000 & 0.000 & 0.000 & 0.000 & 0.000 & 0.000 \\
\hline G. cap and truncatum TOT & 0.000 & 0.358 & 0.000 & 0.287 & 0.130 & 0.000 & 0.000 \\
\hline Navicula gastrum & 0.288 & 0.000 & 0.121 & 0.000 & 0.000 & 0.000 & 0.000 \\
\hline Nav. cryptocephala & 0.288 & 0.000 & 0.726 & 0.000 & 0.130 & 0.143 & 0.000 \\
\hline cf. Nav. cryptotonella & 0.000 & 1.971 & 0.967 & 0.000 & 0.000 & 0.000 & 0.300 \\
\hline Eolimna minima & 0.719 & 1.613 & 0.726 & 1.433 & 0.000 & 0.000 & 0.000 \\
\hline Navicula pseudoventralis & 0.432 & 0.000 & 0.000 & 0.430 & 0.000 & 0.000 & 0.000 \\
\hline Sellaphora pupula & 1.007 & 0.358 & 0.000 & 0.000 & 0.000 & 0.286 & 0.200 \\
\hline Navicula radiosa & 0.000 & 0.000 & 0.000 & 0.860 & 0.000 & 0.000 & 0.000 \\
\hline Navicula seminulum & 0.000 & 0.358 & 0.000 & 0.000 & 0.000 & 0.000 & 0.000 \\
\hline Navicula tuscula & 0.000 & 0.000 & 0.000 & 0.000 & 0.000 & 0.000 & 0.100 \\
\hline Navicula veneta & 0.144 & 0.000 & 0.000 & 0.000 & 0.000 & 0.000 & 0.000 \\
\hline Nitzschia angustata & 0.000 & 0.358 & 0.000 & 0.000 & 0.000 & 0.000 & 0.000 \\
\hline Nitzschia dissipata & 0.576 & 0.179 & 0.121 & 0.287 & 0.260 & 0.000 & 0.000 \\
\hline Nitzschia flexoides & 0.000 & 0.000 & 0.000 & 0.000 & 0.000 & 0.000 & 0.000 \\
\hline Nitzschia fonticola & 1.727 & 2.509 & 1.935 & 1.003 & 0.519 & 0.143 & 0.000 \\
\hline Nitzschia gracilis & 2.158 & 0.358 & 0.363 & 0.000 & 0.649 & 0.286 & 0.000 \\
\hline Nitzschia palea & 0.000 & 0.000 & 0.121 & 0.430 & 0.519 & 0.858 & 0.000 \\
\hline Rhopalodia gibba & 0.000 & 0.000 & 0.000 & 0.000 & 0.000 & 0.000 & 0.000 \\
\hline Staur. anceps v. gracilis & 0.000 & 0.000 & 0.000 & 0.000 & 0.000 & 0.000 & 0.000 \\
\hline Stephano. medius & 12.950 & 0.000 & 3.990 & 0.143 & 0.260 & 0.286 & 0.000 \\
\hline Tabellaria quadriseptata & 0.863 & 0.717 & 0.000 & 0.000 & 0.000 & 0.000 & 0.000 \\
\hline A. exigua v. heterovalvata & 0.000 & 0.000 & 0.121 & 0.000 & 0.000 & 0.000 & 0.000 \\
\hline Achnanthes holsatica & 0.288 & 0.538 & 0.121 & 0.287 & 0.130 & 0.000 & 0.000 \\
\hline Ach. jackii form 1 & 0.000 & 0.000 & 0.000 & 1.433 & 0.519 & 0.143 & 0.000 \\
\hline
\end{tabular}




\begin{tabular}{|c|c|c|c|c|c|c|c|}
\hline \multicolumn{8}{|c|}{ Diatom percent abundance: Haynes Lake, Ontario } \\
\hline \multirow[t]{2}{*}{ Taxon } & \multicolumn{7}{|c|}{ Core Depth } \\
\hline & $1 \mathrm{~cm}$ & $5 \mathrm{~cm}$ & $11 \mathrm{~cm}$ & $15 \mathrm{~cm}$ & $20 \mathrm{~cm}$ & $25 \mathrm{~cm}$ & $30 \mathrm{~cm}$ \\
\hline Ach. jackii form2 & 0.144 & 0.358 & 0.121 & 0.000 & 0.000 & 0.000 & 0.000 \\
\hline Ach. lanceolata v. dubia & 0.000 & 0.000 & 0.121 & 0.000 & 0.000 & 0.000 & 0.000 \\
\hline Achnanthes saprophila & 1.439 & 9.140 & 4.111 & 3.438 & 0.909 & 1.574 & 0.200 \\
\hline Brach. microcephala & 0.000 & 0.538 & 0.121 & 0.716 & 0.390 & 1.001 & 0.699 \\
\hline Cyclotella glomerata & 1.295 & 0.000 & 0.242 & 0.000 & 0.000 & 0.000 & 0.000 \\
\hline Cymatopleura elliptica & 0.144 & 0.000 & 0.000 & 0.143 & 0.000 & 0.000 & 0.000 \\
\hline Cymbella sp1 & 0.000 & 0.000 & 0.000 & 0.000 & 0.000 & 0.000 & 0.100 \\
\hline cf. Cymbella parva & 0.576 & 0.717 & 0.121 & 0.430 & 0.130 & 1.717 & 0.000 \\
\hline Encyo. microcephala & 3.022 & 3.405 & 1.572 & 1.146 & 1.299 & 0.572 & 0.000 \\
\hline Denticula subtilis & 0.000 & 0.000 & 0.000 & 0.000 & 0.000 & 0.000 & 0.300 \\
\hline Eolimna sp1 & 0.863 & 0.000 & 0.242 & 1.433 & 0.000 & 0.000 & 0.000 \\
\hline Eolimna sp2 & 0.000 & 0.717 & 0.121 & 0.573 & 0.519 & 0.000 & 0.000 \\
\hline Eolimna sp4 & 0.432 & 0.896 & 0.242 & 0.143 & 0.000 & 0.000 & 0.000 \\
\hline Eolimna minima2 & 0.000 & 0.000 & 0.000 & 0.143 & 0.000 & 0.143 & 0.000 \\
\hline Eunotia flexuosa & 0.000 & 0.000 & 0.000 & 0.000 & 0.000 & 0.000 & 0.000 \\
\hline Fragilaria sp1 & 0.000 & 0.000 & 0.242 & 0.000 & 0.000 & 0.000 & 0.000 \\
\hline Frag. Pinn. v. lanceolat & 0.000 & 0.538 & 0.242 & 0.430 & 0.000 & 0.000 & 0.000 \\
\hline Frag. ulna v. danica & 1.583 & 0.000 & 0.000 & 0.000 & 0.000 & 0.000 & 0.000 \\
\hline Gomphonema sp2 & 0.000 & 0.358 & 0.000 & 0.000 & 0.000 & 0.000 & 0.100 \\
\hline Gomphonema sp3 & 0.000 & 0.000 & 0.242 & 0.000 & 0.000 & 0.143 & 0.000 \\
\hline Gomphonema sp4 & 0.000 & 0.000 & 0.000 & 0.000 & 0.000 & 0.000 & 0.000 \\
\hline Gomphonema cf. intricatum & 0.000 & 0.000 & 0.000 & 0.000 & 0.000 & 0.000 & 0.000 \\
\hline Hantzschia amphioxys & 0.000 & 0.000 & 0.121 & 0.000 & 0.000 & 0.000 & 0.000 \\
\hline Navicula sp1 & 0.000 & 0.179 & 0.000 & 0.000 & 0.000 & 0.000 & 0.000 \\
\hline Navicula sp2 & 1.007 & 0.000 & 0.000 & 0.287 & 0.519 & 0.143 & 0.000 \\
\hline Navicula sp3 & 0.288 & 0.538 & 0.000 & 0.000 & 0.000 & 0.429 & 0.000 \\
\hline Navicula sp6 & 0.000 & 0.000 & 0.000 & 0.000 & 0.000 & 0.000 & 0.000 \\
\hline Navicula chiarae & 0.863 & 0.896 & 0.484 & 0.716 & 0.260 & 1.288 & 0.400 \\
\hline Nav. cryptocephala? & 0.000 & 0.000 & 0.121 & 0.000 & 0.000 & 0.000 & 0.000 \\
\hline Neidium bisulcatum & 0.000 & 0.000 & 0.000 & 0.000 & 0.000 & 0.000 & 0.000 \\
\hline Nitzschia sp1 & 0.576 & 0.000 & 0.000 & 0.000 & 0.000 & 0.000 & 0.000 \\
\hline Nitzschia sp5 & 0.000 & 0.000 & 0.000 & 0.000 & 0.000 & 0.000 & 0.000 \\
\hline Nitzschia agnita & 3.022 & 2.509 & 1.693 & 3.582 & 1.818 & 0.000 & 1.499 \\
\hline Nitzschia amphibia & 0.000 & 0.000 & 0.000 & 0.000 & 0.000 & 0.143 & 0.599 \\
\hline Nitzschia Fragilaria & 0.144 & 0.000 & 0.000 & 0.000 & 0.000 & 0.000 & 0.000 \\
\hline Nitzschia sigmoidea & 0.432 & 0.000 & 0.000 & 0.000 & 0.000 & 0.000 & 0.000 \\
\hline Nitzschia sinuata & 0.000 & 0.000 & 0.605 & 0.143 & 0.000 & 0.000 & 0.000 \\
\hline cf. Pinnularia anglica & 0.000 & 0.000 & 0.121 & 0.000 & 0.000 & 0.000 & 0.000 \\
\hline Pinnularia sp1 & 0.000 & 0.000 & 0.000 & 0.000 & 0.000 & 0.000 & 0.000 \\
\hline Stauroneis intricans & 0.000 & 0.358 & 0.000 & 0.000 & 0.130 & 0.143 & 0.000 \\
\hline Teapot Frag sp3 & 0.000 & 0.000 & 0.000 & 0.000 & 0.000 & 0.000 & 0.000 \\
\hline Epithemia sp1 & 0.000 & 0.000 & 0.000 & 0.000 & 0.000 & 0.000 & 0.000 \\
\hline Eunotia monodon v. monod. & 0.000 & 0.000 & 0.000 & 0.000 & 0.000 & 0.000 & 0.000 \\
\hline Cymbopleura cuspidata & 0.000 & 0.000 & 0.000 & 0.000 & 0.000 & 0.000 & 0.000 \\
\hline Navicula bryophila & 0.000 & 0.000 & 0.000 & 0.000 & 0.000 & 0.000 & 0.000 \\
\hline Navicula abiskoensis & 0.000 & 0.000 & 0.000 & 0.000 & 0.000 & 0.000 & 0.000 \\
\hline sp96 & 0.000 & 0.000 & 0.000 & 0.000 & 0.000 & 0.000 & 0.000 \\
\hline sp96-004 & 0.000 & 0.000 & 0.000 & 0.000 & 0.000 & 0.000 & 0.000 \\
\hline
\end{tabular}




\begin{tabular}{|c|c|c|c|c|c|c|c|}
\hline \multicolumn{8}{|c|}{ Diatom percent abundance: Haynes Lake, Ontario } \\
\hline \multirow[t]{2}{*}{ Taxon } & \multicolumn{7}{|c|}{ Core Depth } \\
\hline & $40 \mathrm{~cm}$ & $45 \mathrm{~cm}$ & $50 \mathrm{~cm}$ & $60 \mathrm{~cm}$ & $75 \mathrm{~cm}$ & $80 \mathrm{~cm}$ & $100 \mathrm{~cm}$ \\
\hline Ach. lanc. lanceolata & 0.000 & 0.000 & 0.000 & 0.000 & 0.000 & 0.000 & 0.000 \\
\hline A. minutissimum total & 0.627 & 4.729 & 0.221 & 0.565 & 0.331 & 0.484 & 0.491 \\
\hline Amphora capulata & 0.000 & 0.231 & 0.000 & 0.000 & 0.331 & 0.000 & 0.000 \\
\hline Brachysira brebissonii & 0.000 & 0.000 & 0.000 & 0.000 & 0.000 & 0.000 & 0.000 \\
\hline Asterionella formosa & 0.000 & 0.000 & 0.000 & 0.000 & 0.000 & 0.000 & 0.000 \\
\hline Cymb. amphicephala & 0.000 & 0.000 & 0.000 & 0.000 & 0.000 & 0.000 & 0.000 \\
\hline Cymbella cesatii & 2.038 & 4.383 & 0.663 & 2.197 & 2.152 & 1.290 & 3.601 \\
\hline Cymbella subcistula & 1.724 & 1.615 & 0.442 & 0.565 & 1.821 & 0.323 & 1.637 \\
\hline Cymbella falaisensis & 0.784 & 4.268 & 0.221 & 0.377 & 0.828 & 0.968 & 2.128 \\
\hline Encyonema minuta & 1.567 & 0.692 & 0.110 & 0.565 & 0.000 & 0.000 & 0.000 \\
\hline Encyonema silesiacum & 0.000 & 2.076 & 0.884 & 0.565 & 2.649 & 0.968 & 1.146 \\
\hline Cocconeis euglyta & 0.000 & 0.231 & 0.000 & 0.000 & 0.000 & 0.000 & 0.000 \\
\hline Cyclotella bodanica & 0.000 & 0.000 & 0.000 & 0.000 & 22.351 & 0.000 & 0.000 \\
\hline Cycotella comensis & 32.915 & 11.995 & 13.370 & 30.948 & 25.993 & 29.677 & 62.848 \\
\hline Cyclo. michiganiana & 9.404 & 5.190 & 16.796 & 47.960 & 21.026 & 31.613 & 12.930 \\
\hline Cyclotella stelligera & 0.000 & 0.115 & 58.453 & 1.444 & 0.000 & 27.903 & 0.000 \\
\hline Eunotia praerupta & 0.000 & 0.461 & 0.110 & 0.377 & 0.497 & 0.000 & 0.327 \\
\hline Fragilaria biceps & 0.000 & 0.807 & 0.000 & 0.314 & 0.000 & 0.161 & 0.164 \\
\hline Fragilaria brevistriata & 0.000 & 0.000 & 0.221 & 0.000 & 0.331 & 0.161 & 0.000 \\
\hline Fragilaria cap. v. gracilis & 5.172 & 0.461 & 0.000 & 0.188 & 0.662 & 0.161 & 0.164 \\
\hline Staurosira co & 0.000 & 0.000 & 0.000 & 0.000 & 0.000 & 0.000 & 0.000 \\
\hline Fragilaria cyclopum & 0.157 & 0.000 & 0.000 & 0.000 & 0.000 & 0.000 & 0.000 \\
\hline Frag. delic & 3.605 & 5.306 & 0.221 & 0.502 & 0.166 & 0.000 & 0.655 \\
\hline Fragilaria leptostauron & 0.000 & 0.346 & 0.663 & 0.188 & 0.331 & 0.000 & 0.000 \\
\hline F. nanana Total & 4.075 & 7.728 & 0.000 & 0.000 & 0.000 & 0.000 & 0.000 \\
\hline Fragilaria pinnata & 0.000 & 0.000 & 0.663 & 0.063 & 0.000 & 0.000 & 0.000 \\
\hline Fragilaria tenera & 4.389 & 1.615 & 0.221 & 0.126 & 0.000 & 0.000 & 0.000 \\
\hline Gomp. acuminatum & 0.157 & 0.231 & 0.000 & 0.063 & 0.000 & 0.000 & 0.327 \\
\hline Gomp angustatum & 0.157 & 0.000 & 0.000 & 0.000 & 0.000 & 0.000 & 0.000 \\
\hline G. cap and G. truncatum TOT & 0.940 & 0.346 & 0.000 & 0.063 & 0.000 & 0.161 & 0.000 \\
\hline Navicula gastrum & 0.000 & 0.000 & 0.000 & 0.000 & 0.000 & 0.000 & 0.000 \\
\hline Nav. cryptocephala & 0.313 & 0.000 & 0.000 & 0.000 & 0.662 & 0.000 & 0.000 \\
\hline cryptotonella & 0.940 & 6.228 & 0.773 & 2.197 & 4.305 & 1.129 & 1.473 \\
\hline Eolimna $\mathrm{m}$ & 0.157 & 0.346 & 0.110 & 0.000 & 0.000 & 0.161 & 0.000 \\
\hline loventralis & 0.000 & 0.000 & 0.000 & 0.000 & 0.000 & 0.000 & 0.000 \\
\hline Sellaphora & 0.627 & 0.923 & 0.552 & 0.439 & 0.497 & 0.000 & 0.000 \\
\hline Navic & 0.784 & 0.807 & 0.000 & 0.063 & 0.166 & 0.000 & 0.655 \\
\hline Navicula seminulum & 0.000 & 0.000 & 0.000 & 0.000 & 0.000 & 0.000 & 0.000 \\
\hline Navicula tuscula & 2.194 & 3.230 & 0.663 & 0.502 & 1.821 & 0.323 & 0.655 \\
\hline Navic & 0.000 & 0.000 & 0.000 & 0.000 & 0.000 & 0.000 & 0.000 \\
\hline Nitzs & 0.157 & 0.000 & 0.000 & 0.000 & 0.000 & 0.000 & 0.000 \\
\hline Nitzs & 0.313 & 0.000 & 0.000 & 0.126 & 0.000 & 0.000 & 0.000 \\
\hline Nitzschia flexoides & 0.313 & 0.000 & 0.000 & 0.000 & 0.000 & 0.000 & 0.000 \\
\hline Nitzsc & 0.000 & 0.000 & 0.000 & 0.000 & 0.000 & 0.000 & 0.000 \\
\hline Nitzschia gracilis & 1.567 & 0.346 & 0.000 & 0.000 & 0.000 & 0.000 & 0.000 \\
\hline Nitzschia palea & 0.000 & 0.231 & 0.000 & 0.000 & 0.000 & 0.000 & 0.000 \\
\hline dia gibba & 1.724 & 3.345 & 0.663 & 0.000 & 1.656 & 0.000 & 0.327 \\
\hline eps v. gracilis & 0.000 & 0.000 & 0.000 & 0.188 & 0.000 & 0.000 & 0.000 \\
\hline Steph & 0.000 & 0.000 & 0.000 & 0.000 & 0.000 & 0.000 & 0.000 \\
\hline iseptata & 0.000 & 0.000 & 0.000 & 0.063 & 0.331 & 0.000 & 0.000 \\
\hline heterovalvata & 0.000 & 0.000 & 0.000 & 0.000 & 0.000 & 0.000 & 0.000 \\
\hline hes holsatica & 0.000 & 0.115 & 0.331 & 0.000 & 0.000 & 0.000 & 0.000 \\
\hline Ach. jackii form 1 & 0.000 & 0.000 & 0.000 & 0.000 & 0.000 & 0.000 & 0.000 \\
\hline Ach. jackii form2 & 0.000 & 0.000 & 0.000 & 0.000 & 0.000 & 0.000 & 0.000 \\
\hline Ach. lanceolata v. dubia & 0.000 & 0.231 & 0.000 & 0.000 & 0.000 & 0.000 & 0.000 \\
\hline Achnanthes saprophila & 4.389 & 2.768 & 0.000 & 0.628 & 0.166 & 0.323 & 0.982 \\
\hline Brach. microcephala & 0.157 & 0.231 & 0.221 & 0.439 & 1.656 & 0.000 & 0.327 \\
\hline Cyclotella glomerata & 0.000 & 0.000 & 0.000 & 0.000 & 0.000 & 0.000 & 0.000 \\
\hline
\end{tabular}




\begin{tabular}{|c|c|c|c|c|c|c|c|}
\hline \multicolumn{8}{|c|}{ Diatom percent abundance: Haynes Lake, Ontario } \\
\hline \multirow[t]{2}{*}{ Taxon } & \multicolumn{7}{|c|}{ Core Depth } \\
\hline & $40 \mathrm{~cm}$ & $45 \mathrm{~cm}$ & $50 \mathrm{~cm}$ & $60 \mathrm{~cm}$ & $75 \mathrm{~cm}$ & $80 \mathrm{~cm}$ & $100 \mathrm{~cm}$ \\
\hline Cymatopleura elliptica & 0.000 & 0.000 & 0.000 & 0.000 & 0.000 & 0.000 & 0.000 \\
\hline Cymbella sp1 & 2.194 & 1.269 & 0.221 & 0.628 & 1.656 & 0.000 & 0.491 \\
\hline cf. Cymbella parva & 0.470 & 0.000 & 0.000 & 0.188 & 0.331 & 0.161 & 0.164 \\
\hline Encyo. microcephala & 3.918 & 3.922 & 0.110 & 1.193 & 0.166 & 1.129 & 2.619 \\
\hline Denticula subtilis & 0.000 & 4.268 & 0.663 & 0.000 & 0.497 & 0.323 & 1.309 \\
\hline Eolimna sp1 & 0.000 & 0.000 & 0.000 & 0.000 & 0.000 & 0.000 & 0.000 \\
\hline Eolimna sp2 & 0.000 & 0.000 & 0.000 & 0.000 & 0.000 & 0.000 & 0.000 \\
\hline Eolimna sp4 & 0.000 & 0.000 & 0.000 & 0.000 & 0.000 & 0.000 & 0.000 \\
\hline Eolimna minima2 & 0.000 & 0.000 & 0.000 & 0.000 & 0.000 & 0.000 & 0.000 \\
\hline Eunotia flexuosa & 0.157 & 0.115 & 0.000 & 0.126 & 0.166 & 0.000 & 0.327 \\
\hline Fragilaria sp1 & 0.157 & 0.000 & 0.000 & 0.000 & 0.000 & 0.000 & 0.000 \\
\hline Frag. Pinn. v. lanceolat & 0.157 & 0.000 & 0.000 & 0.063 & 0.331 & 0.000 & 0.000 \\
\hline Frag. ulna v. danica & 1.411 & 2.076 & 0.110 & 0.251 & 0.000 & 0.000 & 0.327 \\
\hline Gomphonema sp2 & 0.000 & 0.000 & 0.000 & 0.000 & 0.000 & 0.000 & 0.000 \\
\hline Gomphonema sp3 & 0.313 & 0.000 & 0.000 & 0.000 & 0.662 & 0.000 & 0.000 \\
\hline Gomphonema sp4 & 0.470 & 2.537 & 0.773 & 1.569 & 1.159 & 0.484 & 0.982 \\
\hline Gomphonema cf. intricatum & 0.000 & 1.269 & 0.442 & 0.000 & 0.662 & 0.000 & 0.164 \\
\hline Hantzschia amphioxys & 0.000 & 0.000 & 0.000 & 0.000 & 0.000 & 0.000 & 0.000 \\
\hline Navicula sp1 & 0.000 & 0.000 & 0.000 & 0.000 & 0.000 & 0.000 & 0.000 \\
\hline Navicula sp2 & 0.000 & 0.000 & 0.000 & 0.000 & 0.000 & 0.000 & 0.000 \\
\hline Navicula sp3 & 0.000 & 0.000 & 0.000 & 0.000 & 0.000 & 0.000 & 0.000 \\
\hline Navicula sp6 & 0.940 & 0.346 & 0.000 & 1.067 & 0.000 & 0.323 & 0.327 \\
\hline Navicula chiarae & 4.545 & 0.923 & 0.000 & 1.130 & 0.331 & 0.161 & 1.637 \\
\hline Nav. cryptocephala? & 0.000 & 0.000 & 0.000 & 0.000 & 0.000 & 0.000 & 0.000 \\
\hline Neidium bisulcatum & 0.000 & 0.231 & 0.221 & 0.126 & 0.000 & 0.000 & 0.000 \\
\hline Nitzschia sp1 & 0.157 & 0.000 & 0.000 & 0.000 & 0.000 & 0.000 & 0.164 \\
\hline Nitzschia sp5 & 1.881 & 1.384 & 0.000 & 0.251 & 0.000 & 0.323 & 0.000 \\
\hline Nitzschia agnita & 0.784 & 2.537 & 0.000 & 0.000 & 0.000 & 0.000 & 0.000 \\
\hline Nitzschia amphibia & 0.313 & 6.228 & 0.884 & 1.569 & 2.980 & 1.290 & 0.491 \\
\hline Nitzschia Fragilaria & 0.000 & 0.000 & 0.000 & 0.000 & 0.000 & 0.000 & 0.000 \\
\hline Nitzschia sigmoidea & 0.000 & 0.000 & 0.000 & 0.000 & 0.000 & 0.000 & 0.000 \\
\hline Nitzschia sinuata & 0.000 & 0.000 & 0.000 & 0.000 & 0.000 & 0.000 & 0.000 \\
\hline cf. Pinnularia anglica & 0.000 & 0.000 & 0.000 & 0.000 & 0.000 & 0.000 & 0.000 \\
\hline Pinnularia sp1 & 0.000 & 0.923 & 0.000 & 0.126 & 0.000 & 0.000 & 0.164 \\
\hline Stauroneis intricans & 0.000 & 0.000 & 0.000 & 0.000 & 0.000 & 0.000 & 0.000 \\
\hline Teapot Frag sp3 & 0.784 & 0.000 & 0.000 & 0.000 & 0.000 & 0.000 & 0.000 \\
\hline Epithemia sp1 & 0.000 & 0.346 & 0.000 & 0.000 & 0.000 & 0.000 & 0.000 \\
\hline Eunotia monodon v. monod. & 0.000 & 0.000 & 0.000 & 0.000 & 0.331 & 0.000 & 0.000 \\
\hline Cymbopleura cuspidata & 0.000 & 0.000 & 0.000 & 0.000 & 0.000 & 0.000 & 0.000 \\
\hline Navicula bryophila & 0.000 & 0.000 & 0.000 & 0.000 & 0.000 & 0.000 & 0.000 \\
\hline Navicula abiskoensis & 0.000 & 0.000 & 0.000 & 0.000 & 0.000 & 0.000 & 0.000 \\
\hline sp96 & 0.000 & 0.000 & 0.000 & 0.000 & 0.000 & 0.000 & 0.000 \\
\hline sp96-004 & 0.000 & 0.000 & 0.000 & 0.000 & 0.000 & 0.000 & 0.000 \\
\hline
\end{tabular}




\begin{tabular}{|c|c|c|c|c|c|c|}
\hline \multicolumn{7}{|c|}{ Diatom percent abundance: Haynes Lake, Ontario } \\
\hline \multirow[t]{2}{*}{ Taxon } & \multicolumn{6}{|c|}{ Core Depth } \\
\hline & $110 \mathrm{~cm}$ & $120 \mathrm{~cm}$ & $130 \mathrm{~cm}$ & $140 \mathrm{~cm}$ & $160 \mathrm{~cm}$ & $188.5 \mathrm{~cm}$ \\
\hline Ach. lanc. lanceolata & 0.000 & 0.000 & 0.000 & 0.000 & 0.000 & 0.000 \\
\hline A. minutissimum total & 0.606 & 0.433 & 3.361 & 0.988 & 1.059 & 0.123 \\
\hline Amphora capulata & 0.076 & 0.000 & 0.000 & 0.000 & 0.000 & 0.000 \\
\hline Brachysira brebissonii & 0.000 & 0.000 & 0.000 & 0.000 & 0.106 & 1.472 \\
\hline Asterionella formosa & 0.000 & 0.000 & 0.000 & 0.000 & 0.000 & 0.000 \\
\hline Cymb. amphicephala & 0.000 & 0.000 & 0.000 & 0.000 & 0.000 & 0.000 \\
\hline Cymbella cesatii & 0.379 & 2.091 & 5.042 & 1.153 & 1.801 & 2.699 \\
\hline Cymbella subcistula & 0.114 & 0.505 & 1.541 & 0.165 & 0.530 & 2.331 \\
\hline Cymbella falaisensis & 1.061 & 0.865 & 0.700 & 0.494 & 1.271 & 0.368 \\
\hline Encyonema minuta & 0.455 & 0.216 & 0.420 & 0.000 & 0.000 & 0.613 \\
\hline Encyonema silesiacum & 0.227 & 1.586 & 3.221 & 1.153 & 4.767 & 5.644 \\
\hline Cocconeis euglyta & 0.000 & 0.000 & 0.000 & 0.165 & 0.000 & 0.000 \\
\hline Cyclotella bodanica & 0.417 & 5.191 & 0.000 & 1.318 & 5.932 & 0.613 \\
\hline Cycotella comensis & 6.404 & 14.564 & 13.866 & 28.501 & 18.962 & 25.031 \\
\hline Cyclo. michiganiana & 7.503 & 20.692 & 20.028 & 25.535 & 26.271 & 7.117 \\
\hline Cyclotella stelligera & 76.279 & 37.635 & 5.462 & 0.494 & 26.695 & 13.620 \\
\hline Eunotia praerupta & 0.076 & 0.288 & 0.000 & 0.165 & 0.000 & 0.491 \\
\hline Fragilaria biceps & 0.038 & 0.072 & 0.140 & 0.329 & 0.106 & 0.000 \\
\hline Fragilaria brevistriata & 0.000 & 0.072 & 0.000 & 0.000 & 0.000 & 0.245 \\
\hline Fragilaria cap. v. gracilis & 0.303 & 0.793 & 2.661 & 1.153 & 0.318 & 1.472 \\
\hline Staurosira construens & 0.000 & 0.000 & 0.000 & 0.000 & 0.000 & 0.000 \\
\hline Fragilaria cyclopum & 0.000 & 0.216 & 0.000 & 0.165 & 0.000 & 0.000 \\
\hline Frag. delicatissima & 0.796 & 2.668 & 10.224 & 5.931 & 0.318 & 0.491 \\
\hline Fragilaria leptostauron & 0.038 & 0.000 & 0.560 & 0.000 & 0.000 & 0.245 \\
\hline F. nanana Total & 0.531 & 0.577 & 6.583 & 2.801 & 0.106 & 0.245 \\
\hline Fragilaria pinnata & 0.076 & 0.000 & 0.000 & 0.000 & 0.106 & 0.000 \\
\hline Fragilaria tenera & 0.189 & 0.144 & 2.101 & 0.000 & 0.000 & 0.123 \\
\hline Gomp. acuminatum & 0.000 & 0.000 & 0.000 & 0.000 & 0.000 & 0.123 \\
\hline Gomp angustatum & 0.000 & 0.000 & 0.000 & 0.000 & 0.000 & 0.000 \\
\hline G. cap and G. truncatum TOT & 0.000 & 0.000 & 0.000 & 0.000 & 0.000 & 0.123 \\
\hline Navicula gastrum & 0.000 & 0.000 & 0.000 & 0.000 & 0.000 & 0.368 \\
\hline Nav. cryptocephala & 0.114 & 0.000 & 0.000 & 0.000 & 0.000 & 0.491 \\
\hline cf. Nav. cryptotonella & 0.455 & 1.514 & 3.641 & 3.789 & 1.589 & 1.840 \\
\hline Eolimna minima & 0.000 & 0.000 & 0.000 & 0.165 & 0.106 & 0.000 \\
\hline Navicula pseudoventralis & 0.000 & 0.000 & 0.000 & 0.000 & 0.000 & 0.000 \\
\hline Sellaphora pupula & 0.000 & 0.721 & 0.000 & 0.000 & 0.530 & 0.613 \\
\hline Navicula radiosa & 0.000 & 0.433 & 1.261 & 0.659 & 0.424 & 1.350 \\
\hline Navicula seminulum & 0.000 & 0.000 & 0.000 & 0.000 & 0.000 & 0.000 \\
\hline Navicula tuscula & 0.341 & 0.793 & 1.821 & 1.977 & 0.106 & 9.448 \\
\hline Navicula veneta & 0.000 & 0.000 & 0.000 & 0.000 & 0.000 & 0.000 \\
\hline Nitzschia angustata & 0.000 & 0.000 & 0.000 & 0.000 & 0.000 & 0.000 \\
\hline Nitzschia dissipata & 0.000 & 0.000 & 0.000 & 0.329 & 0.000 & 0.245 \\
\hline Nitzschia flexoides & 0.000 & 0.000 & 0.000 & 0.000 & 0.000 & 0.000 \\
\hline Nitzschia fonticola & 0.000 & 0.000 & 0.000 & 0.000 & 0.000 & 0.000 \\
\hline Nitzschia gracilis & 0.000 & 0.000 & 0.000 & 0.329 & 0.000 & 0.245 \\
\hline Nitzschia palea & 0.000 & 0.000 & 0.000 & 0.000 & 0.000 & 0.000 \\
\hline Rhopalodia gibba & 0.076 & 0.000 & 0.560 & 1.153 & 0.530 & 0.859 \\
\hline Stauroneis anceps v. gracilis & 0.000 & 0.000 & 0.000 & 0.000 & 0.000 & 0.000 \\
\hline Stephano. medius & 0.114 & 0.000 & 0.000 & 0.000 & 0.000 & 0.000 \\
\hline Tabellaria quadriseptata & 0.000 & 0.000 & 0.140 & 0.000 & 0.000 & 0.000 \\
\hline Ach. exigua v. heterovalvata & 0.000 & 0.000 & 0.000 & 0.000 & 0.212 & 0.000 \\
\hline Achnanthes holsatica & 0.000 & 0.072 & 0.000 & 0.000 & 0.000 & 0.000 \\
\hline Ach. jackii form 1 & 0.000 & 0.144 & 0.280 & 1.318 & 0.000 & 0.000 \\
\hline Ach. jackii form2 & 0.000 & 0.000 & 0.000 & 0.000 & 0.000 & 0.000 \\
\hline Ach. lanceolata v. dubia & 0.000 & 0.000 & 0.000 & 0.000 & 0.000 & 0.000 \\
\hline Achnanthes saprophila & 0.682 & 0.793 & 1.541 & 0.988 & 1.483 & 0.245 \\
\hline Brach. microcephala & 0.114 & 0.288 & 1.821 & 1.318 & 0.212 & 2.331 \\
\hline Cyclotella glomerata & 0.000 & 0.000 & 0.000 & 0.000 & 0.000 & 0.000 \\
\hline
\end{tabular}




\begin{tabular}{|c|c|c|c|c|c|c|}
\hline \multicolumn{7}{|c|}{ Diatom percent abundance: Haynes Lake, Ontario } \\
\hline \multirow[t]{2}{*}{ Taxon } & \multicolumn{6}{|c|}{ Core Depth } \\
\hline & $110 \mathrm{~cm}$ & $120 \mathrm{~cm}$ & $130 \mathrm{~cm}$ & $140 \mathrm{~cm}$ & $160 \mathrm{~cm}$ & $188.5 \mathrm{~cm}$ \\
\hline Cymatopleura elliptica & 0.000 & 0.000 & 0.000 & 0.000 & 0.000 & 0.000 \\
\hline Cymbella sp1 & 0.265 & 0.793 & 1.401 & 0.165 & 0.530 & 0.123 \\
\hline cf. Cymbella parva & 0.000 & 0.000 & 0.000 & 0.000 & 0.000 & 3.067 \\
\hline Encyo. microcephala & 0.872 & 1.730 & 3.361 & 2.471 & 0.212 & 0.245 \\
\hline Denticula subtilis & 0.114 & 0.793 & 0.700 & 1.318 & 0.530 & 3.190 \\
\hline Eolimna sp1 & 0.000 & 0.000 & 0.000 & 0.000 & 0.000 & 0.000 \\
\hline Eolimna sp2 & 0.000 & 0.000 & 0.000 & 0.000 & 0.000 & 0.000 \\
\hline Eolimna sp4 & 0.000 & 0.000 & 0.000 & 0.000 & 0.000 & 0.000 \\
\hline Eolimna minima2 & 0.000 & 0.000 & 0.000 & 0.000 & 0.000 & 0.000 \\
\hline Eunotia flexuosa & 0.000 & 0.144 & 0.000 & 0.000 & 0.212 & 0.000 \\
\hline Fragilaria sp1 & 0.000 & 0.000 & 0.000 & 0.165 & 0.000 & 0.000 \\
\hline Frag. Pinn. v. lanceolat & 0.000 & 0.000 & 0.140 & 0.000 & 0.000 & 0.000 \\
\hline Frag. ulna v. danica & 0.076 & 0.649 & 1.261 & 3.460 & 0.318 & 0.123 \\
\hline Gomphonema sp2 & 0.076 & 0.000 & 0.000 & 0.000 & 0.000 & 0.000 \\
\hline Gomphonema sp3 & 0.000 & 0.000 & 0.000 & 0.329 & 0.318 & 1.840 \\
\hline Gomphonema sp4 & 0.114 & 0.288 & 0.420 & 0.165 & 1.483 & 1.104 \\
\hline Gomphonema ct. intricatum & 0.076 & 0.216 & 1.120 & 0.494 & 0.106 & 0.982 \\
\hline Hantzschia amphioxys & 0.000 & 0.000 & 0.000 & 0.000 & 0.000 & 0.123 \\
\hline Navicula sp1 & 0.000 & 0.000 & 0.000 & 0.000 & 0.000 & 0.000 \\
\hline Navicula sp2 & 0.114 & 0.000 & 0.560 & 0.000 & 0.000 & 0.000 \\
\hline Navicula sp3 & 0.000 & 0.000 & 0.000 & 0.000 & 0.000 & 0.245 \\
\hline Navicula sp6 & 0.000 & 0.433 & 0.000 & 0.988 & 0.000 & 0.000 \\
\hline Navicula chiarae & 0.303 & 0.360 & 0.840 & 1.318 & 0.318 & 0.245 \\
\hline Nav. cryptocephala? & 0.000 & 0.000 & 0.000 & 0.000 & 0.000 & 0.000 \\
\hline Neidium bisulcatum & 0.000 & 0.000 & 0.140 & 0.000 & 0.106 & 0.000 \\
\hline Nitzschia sp1 & 0.000 & 0.000 & 0.000 & 0.000 & 0.000 & 0.000 \\
\hline Nitzschia sp5 & 0.114 & 0.144 & 0.840 & 2.142 & 0.212 & 0.368 \\
\hline Nitzschia agnita & 0.227 & 0.360 & 1.120 & 0.659 & 0.318 & 1.104 \\
\hline Nitzschia amphibia & 0.076 & 0.649 & 0.700 & 3.295 & 1.271 & 5.644 \\
\hline Nitzschia Fragilaria & 0.000 & 0.000 & 0.000 & 0.000 & 0.000 & 0.000 \\
\hline Nitzschia sigmoidea & 0.000 & 0.000 & 0.000 & 0.000 & 0.000 & 0.000 \\
\hline Nitzschia sinuata & 0.000 & 0.000 & 0.000 & 0.000 & 0.000 & 0.000 \\
\hline cf. Pinnularia anglica & 0.000 & 0.000 & 0.000 & 0.000 & 0.000 & 0.000 \\
\hline Pinnularia sp1 & 0.000 & 0.072 & 0.140 & 0.494 & 0.212 & 0.000 \\
\hline Stauroneis intricans & 0.000 & 0.000 & 0.000 & 0.000 & 0.000 & 0.000 \\
\hline Teapot Frag sp3 & 0.000 & 0.000 & 0.000 & 0.000 & 0.000 & 0.000 \\
\hline Epithemia sp1 & 0.114 & 0.000 & 0.280 & 0.000 & 0.000 & 0.000 \\
\hline Eunotia monodon v. monod. & 0.000 & 0.000 & 0.000 & 0.000 & 0.000 & 0.000 \\
\hline Cymbopleura cuspidata & 0.000 & 0.000 & 0.000 & 0.000 & 0.106 & 0.000 \\
\hline Navicula bryophila & 0.000 & 0.000 & 0.000 & 0.000 & 0.106 & 0.000 \\
\hline Navicula abiskoensis & 0.000 & 0.000 & 0.000 & 0.000 & 0.106 & 0.000 \\
\hline sp96 & 0.000 & 0.000 & 0.000 & 0.000 & 0.000 & 0.245 \\
\hline sp96-004 & 0.000 & 0.000 & 0.000 & 0.000 & 0.000 & 0.123 \\
\hline
\end{tabular}




\section{Appendix 2. Haynes Lake Diatom Subsampling Data}

\begin{tabular}{|ccccc|}
\hline $\begin{array}{c}\text { Sample } \\
\text { Depth } \\
(\mathrm{cm})\end{array}$ & $\begin{array}{c}\text { Total Wet } \\
\text { Weight } \\
(\mathrm{g})\end{array}$ & $\begin{array}{c}\text { Total Dry } \\
\text { Weight } \\
(\mathrm{g})\end{array}$ & $\begin{array}{c}\text { Water } \\
\text { Weight } \\
(\mathrm{g})\end{array}$ & $\begin{array}{c}\text { Subsample } \\
\text { Weight } \\
(\mathrm{g})\end{array}$ \\
\hline 1.0 & 1.0079 & 0.3944 & 0.6135 & 0.0579 \\
5.0 & 1.0471 & 0.3340 & 0.7131 & 0.0464 \\
11.0 & 1.1683 & 0.5521 & 0.6162 & 0.0573 \\
15.0 & 1.4903 & 0.8708 & 0.6195 & 0.0517 \\
20.0 & 1.2691 & 0.6603 & 0.6088 & 0.0456 \\
25.0 & 1.2798 & 0.7238 & 0.5560 & 0.0462 \\
30.0 & 1.4837 & 0.7930 & 0.6907 & 0.0468 \\
40.0 & 1.1656 & 0.3200 & 0.8456 & 0.0446 \\
45.0 & 1.1095 & 0.2485 & 0.8610 & 0.0399 \\
50.0 & 0.9606 & 0.1106 & 0.8500 & 0.0342 \\
60.0 & 1.1012 & 0.2190 & 0.8822 & 0.0467 \\
75.0 & 1.0277 & 0.0705 & 0.9572 & 0.0323 \\
80.0 & 0.9739 & 0.0972 & 0.8767 & 0.0449 \\
100.0 & 0.8481 & 0.0755 & 0.7726 & 0.0472 \\
110.0 & 0.9175 & 0.1789 & 0.7386 & 0.0346 \\
120.0 & 0.9504 & 0.1601 & 0.7903 & 0.0543 \\
130.0 & 0.9108 & 0.1681 & 0.7427 & 0.0335 \\
140.0 & 1.1469 & 0.1012 & 1.0457 & 0.0450 \\
160.0 & 0.8548 & 0.0784 & 0.7764 & 0.0334 \\
188.5 & 0.8238 & 0.0778 & 0.7460 & 0.0330 \\
\hline & & & &
\end{tabular}




\section{Appendix 3. Thecamoebian percent abundance data: Haynes Lake, Ontario}

\begin{tabular}{|c|c|c|c|c|c|c|c|c|}
\hline \multicolumn{2}{|c|}{ Thecamoebian Percent Abundance: Haynes Lake } \\
\hline $\begin{array}{l}\text { Core } \\
\text { Depth } \\
\text { (cm) }\end{array}$ & $\begin{array}{l}\text { Curcurbitella } \\
\text { tricuspis }\end{array}$ & $\begin{array}{l}\text { Arcella } \\
\text { vulgaris }\end{array}$ & $\begin{array}{l}\text { Centropyxis } \\
\text { aculeata } \\
\text { "aculeata" }\end{array}$ & $\begin{array}{l}\text { Centropyxis } \\
\text { aculeata } \\
\text { "discoides" }\end{array}$ & $\begin{array}{l}\text { Centropyxis } \\
\text { constricta } \\
\text { "aerophila" }\end{array}$ & $\begin{array}{l}\text { Centropyxis } \\
\text { constricta } \\
\text { "constricta" }\end{array}$ & $\begin{array}{l}\text { Difflugia } \\
\text { oblonga } \\
\text { "oblonga" }\end{array}$ & $\begin{array}{l}\text { Difflugia } \\
\text { oblonga } \\
\text { "bryophila" }\end{array}$ \\
\hline 1 & 62.73 & 7.45 & 19.88 & 2.48 & 0.62 & 0.62 & 4.35 & 0.00 \\
5 & 25.32 & 1.27 & 35.76 & 5.70 & 0.32 & 0.00 & 16.46 & 1.58 \\
11 & 76.03 & 2.74 & 3.42 & 2.05 & 0.00 & 0.00 & 0.00 & 0.00 \\
15 & 28.16 & 1.94 & 47.57 & 8.74 & 0.00 & 0.00 & 1.94 & 0.00 \\
20 & 30.77 & 7.69 & 49.23 & 7.69 & 0.00 & 1.54 & 3.08 & 0.00 \\
25 & 31.18 & 1.08 & 53.76 & 7.53 & 1.08 & 0.00 & 2.15 & 0.00 \\
30 & 39.83 & 1.69 & 44.92 & 8.47 & 0.85 & 0.00 & 1.69 & 0.00 \\
40 & 5.00 & 12.00 & 73.00 & 1.00 & 0.00 & 0.00 & 1.00 & 0.00 \\
45 & 2.67 & 18.22 & 64.00 & 5.78 & 0.89 & 0.89 & 0.89 & 0.00 \\
50 & 4.23 & 38.03 & 53.52 & 0.70 & 0.70 & 0.70 & 0.00 & 0.00 \\
60 & 47.06 & 49.02 & 0.00 & 0.00 & 0.00 & 0.00 & 3.92 & 0.00 \\
75 & 11.32 & 71.70 & 1.89 & 15.09 & 0.00 & 0.00 & 0.00 & 0.00 \\
80 & 10.94 & 66.04 & 1.13 & 10.57 & 0.00 & 0.38 & 10.94 & 0.00 \\
100 & 23.17 & 59.76 & 0.00 & 13.41 & 0.00 & 0.00 & 3.05 & 0.00 \\
110 & 31.08 & 62.84 & 4.05 & 0.00 & 0.00 & 0.00 & 0.00 & 0.00 \\
120 & 34.91 & 35.38 & 7.08 & 2.36 & 0.00 & 0.00 & 18.40 & 0.00 \\
130 & 18.10 & 72.38 & 0.00 & 9.52 & 0.00 & 0.00 & 0.00 & 0.00 \\
140 & 2.92 & 77.19 & 0.00 & 19.30 & 0.00 & 0.00 & 0.00 & 0.00 \\
160 & 8.61 & 78.15 & 0.00 & 13.25 & 0.00 & 0.00 & 0.00 & 0.00 \\
188.5 & 0.00 & 67.16 & 12.69 & 18.66 & 0.00 & 1.49 & 0.00 & 0.00 \\
\hline
\end{tabular}

\begin{tabular}{|c|c|c|c|c|c|c|c|c|}
\hline \multicolumn{8}{|c|}{ Thecamoebian Percent Abundance: Haynes Lake } \\
\hline $\begin{array}{l}\text { Core } \\
\text { Depth } \\
\text { (cm) }\end{array}$ & $\begin{array}{l}\text { Difflugia } \\
\text { oblonga } \\
\text { "glans" }\end{array}$ & $\begin{array}{l}\text { Difflugia } \\
\text { urceolata } \\
\text { "elongata" }\end{array}$ & $\begin{array}{l}\text { Difflugia } \\
\text { urceolata } \\
\text { "urceolata" }\end{array}$ & $\begin{array}{l}\text { Difflugia } \\
\text { corona }\end{array}$ & $\begin{array}{l}\text { Difflugia } \\
\text { bidens }\end{array}$ & $\begin{array}{l}\text { Difflugia } \\
\text { protaeioformes } \\
\text { "acuminata" }\end{array}$ & $\begin{array}{l}\text { Difflugia } \\
\text { protaeioformes } \\
\text { "amphoralis" }\end{array}$ & $\begin{array}{l}\text { Lesquereusia } \\
\text { spiralis }\end{array}$ \\
\hline 1 & 0.00 & 0.00 & 0.00 & 1.24 & 0.00 & 0.62 & 0.00 & 0.00 \\
5 & 2.22 & 0.32 & 0.95 & 5.38 & 0.32 & 3.48 & 0.32 & 0.63 \\
11 & 0.00 & 13.01 & 0.00 & 2.05 & 0.00 & 0.00 & 0.00 & 0.68 \\
15 & 0.00 & 0.00 & 0.00 & 11.65 & 0.00 & 0.00 & 0.00 & 0.00 \\
20 & 0.00 & 0.00 & 0.00 & 0.00 & 0.00 & 0.00 & 0.00 & 0.00 \\
25 & 0.00 & 0.00 & 0.00 & 0.00 & 0.00 & 3.23 & 0.00 & 0.00 \\
30 & 0.00 & 0.00 & 0.00 & 1.69 & 0.00 & 0.00 & 0.00 & 0.85 \\
40 & 0.00 & 6.00 & 0.00 & 0.00 & 0.00 & 0.00 & 0.00 & 2.00 \\
45 & 0.00 & 5.78 & 0.00 & 0.89 & 0.00 & 0.00 & 0.00 & 0.00 \\
50 & 0.00 & 1.41 & 0.00 & 0.00 & 0.00 & 0.00 & 0.00 & 0.70 \\
60 & 0.00 & 0.00 & 0.00 & 0.00 & 0.00 & 0.00 & 0.00 & 0.00 \\
75 & 0.00 & 0.00 & 0.00 & 0.00 & 0.00 & 0.00 & 0.00 & 0.00 \\
80 & 0.00 & 0.00 & 0.00 & 0.00 & 0.00 & 0.00 & 0.00 & 0.00 \\
100 & 0.00 & 0.00 & 0.00 & 0.00 & 0.00 & 0.00 & 0.00 & 0.61 \\
110 & 0.00 & 0.00 & 0.00 & 0.00 & 0.00 & 0.00 & 0.00 & 2.03 \\
120 & 0.00 & 0.00 & 0.00 & 0.00 & 0.00 & 0.00 & 0.00 & 1.89 \\
130 & 0.00 & 0.00 & 0.00 & 0.00 & 0.00 & 0.00 & 0.00 & 0.00 \\
140 & 0.00 & 0.00 & 0.00 & 0.58 & 0.00 & 0.00 & 0.00 & 0.00 \\
160 & 0.00 & 0.00 & 0.00 & 0.00 & 0.00 & 0.00 & 0.00 & 0.00 \\
188.5 & 0.00 & 0.00 & 0.00 & 0.00 & 0.00 & 0.00 & 0.00 & 0.00 \\
\hline
\end{tabular}




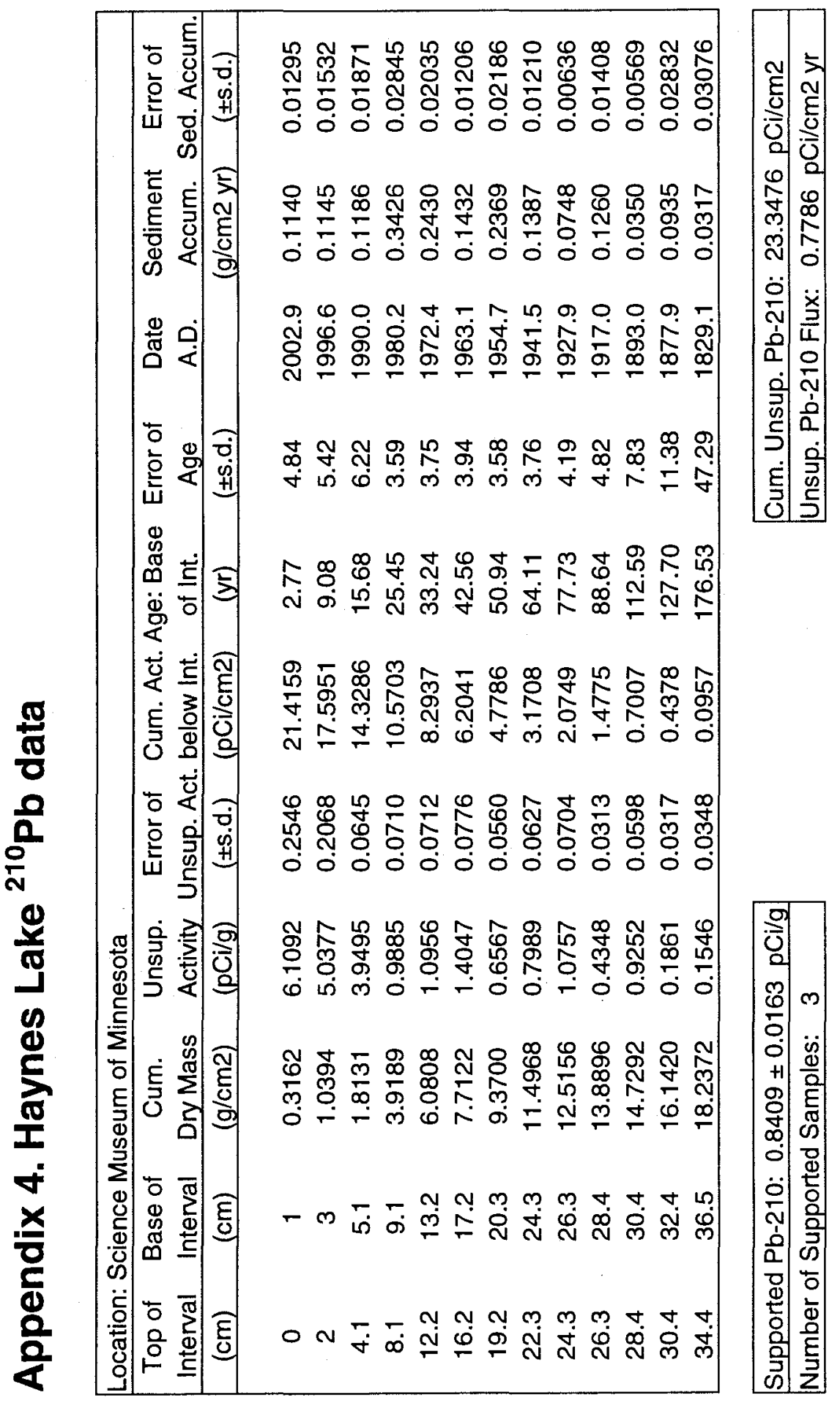




\section{Appendix 5. Haynes Lake Water Chemistry Data}

\begin{tabular}{|c|c|c|c|c|c|c|}
\hline \multicolumn{7}{|c|}{$\begin{array}{l}\text { Date: Aug. } 20 / 05 \\
\text { Atmospheric Pressure: } 98.1 \mathrm{kPa} \\
\text { Location: Site } 1 \text { Haynes Lake } 43^{\prime} 57.548 \mathrm{~N} ; 79^{\prime} 24.481 \mathrm{~W} \\
\text { Water Samples (3) Collected Approx. 1m depth : DC878 } \\
\text { Equipment: YSI Instrument }\end{array}$} \\
\hline $\begin{array}{l}\text { Depth } \\
(\mathrm{m})\end{array}$ & $\begin{array}{c}\text { Temperature } \\
\left({ }^{\circ} \mathrm{C}\right)\end{array}$ & $\begin{array}{c}\text { Dissolved } \\
\text { Oxygen } \\
(\mathrm{mg} / \mathrm{L})\end{array}$ & $\begin{array}{c}\text { Conductance } \\
\mu \mathrm{s} / \mathrm{cm}\end{array}$ & $\begin{array}{l}\text { Conductance } \\
\text { (corr. to } 25^{\circ} \mathrm{C} \text { ) }\end{array}$ & $\begin{array}{c}\text { Dissolved } \\
\text { Oxygen } \\
(\%)\end{array}$ & $\mathrm{pH}$ \\
\hline 0.5 & 23.3 & 5.89 & 784 & 811 & 67.0 & 7.97 \\
\hline 1.0 & 23.3 & 5.80 & 780 & 809 & 66.9 & \\
\hline 2.0 & 23.2 & 5.50 & 780 & 808 & 66.9 & \\
\hline 3.0 & 23.2 & 5.60 & 779 & 807 & 62.0 & \\
\hline 4.0 & 23.0 & 5.50 & 778 & 808 & 65.0 & \\
\hline 5.0 & 19.1 & 5.50 & 795 & 895 & 59.0 & \\
\hline 6.0 & 14.8 & 2.70 & 729 & 911 & 27.0 & \\
\hline 7.0 & 11.5 & 0.87 & 681 & 922 & 8.0 & \\
\hline 8.0 & 9.4 & 0.13 & 656 & 936 & 1.1 & \\
\hline 9.0 & 7.7 & 0.07 & 640 & 957 & 0.6 & \\
\hline 10.0 & 6.7 & 0.16 & 635 & 977 & 1.3 & \\
\hline 11.0 & 6.0 & 0.07 & 644 & 1010 & 0.6 & \\
\hline 12.0 & 5.5 & 0.06 & 670 & 1067 & 0.5 & \\
\hline 13.0 & 5.2 & 0.06 & 715 & 1149 & 0.5 & \\
\hline 14.0 & 5.1 & 0.06 & 731 & 1178 & 0.4 & \\
\hline 15.0 & 5.1 & 0.03 & 750 & 1210 & 0.3 & \\
\hline 16.0 & 5.1 & 0.02 & 749 & 1208 & 0.2 & 7.36 \\
\hline
\end{tabular}

\begin{tabular}{|cccc|}
\hline \multicolumn{4}{|c|}{ Analysis by: Ottawa-Carleton Water Quality Laboratory } \\
\hline $\begin{array}{c}\text { Subsample } \\
\text { Date }\end{array}$ & $\mathrm{pH}$ & $\begin{array}{c}\text { Total } \\
\text { Phosphorus } \\
(\mathrm{mg} / \mathrm{L})\end{array}$ & $\begin{array}{c}\text { Conductivity } \\
(\mu \mathrm{s} / \mathrm{cm})\end{array}$ \\
\hline Aug. 18/05 & 8.03 & 0.012 & 800 \\
\hline
\end{tabular}




\section{Appendix 6. Common diatom species images: Haynes Lake, Ontario}

These images, as well as subsample material and microscope slides, are archived at the Canadian Museum of Nature, Research Division, Ottawa, Ontario.

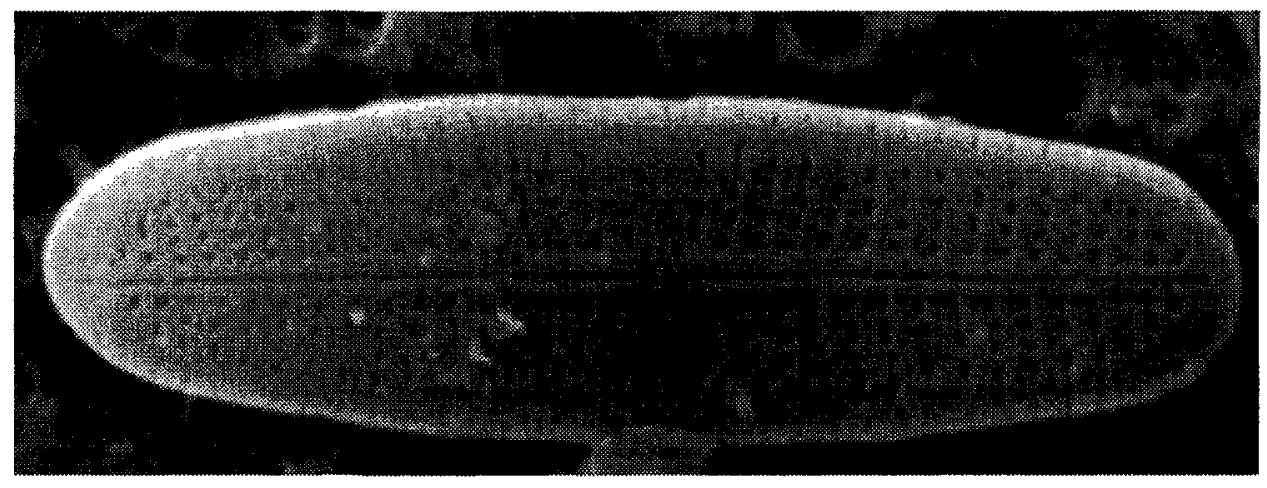

Achnanthidium minutissimum

Core Depth: $1 \mathrm{~cm}$

Length: $9.83 \mu \mathrm{m}$; Width: $2.9 \mu \mathrm{m}$

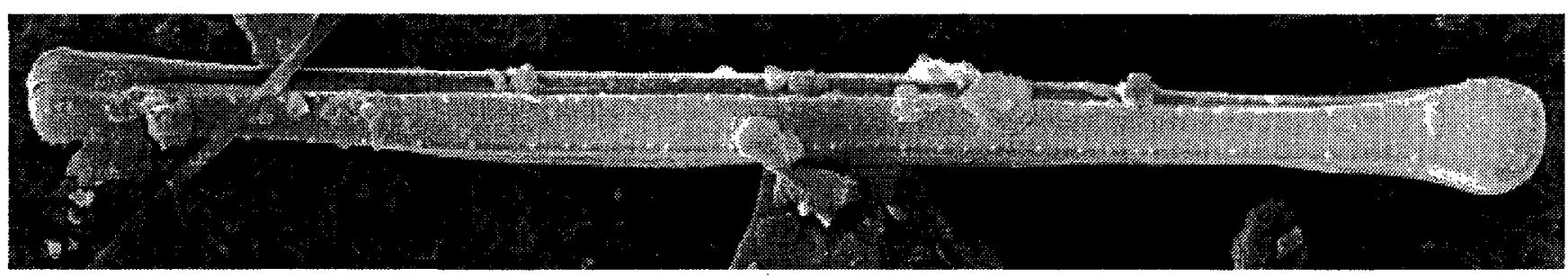

Asterionella formosa

Core Depth: $1 \mathrm{~cm}$

Length: $59.4 \mu \mathrm{m}$; Width: $2.48 \mu \mathrm{m}$ 


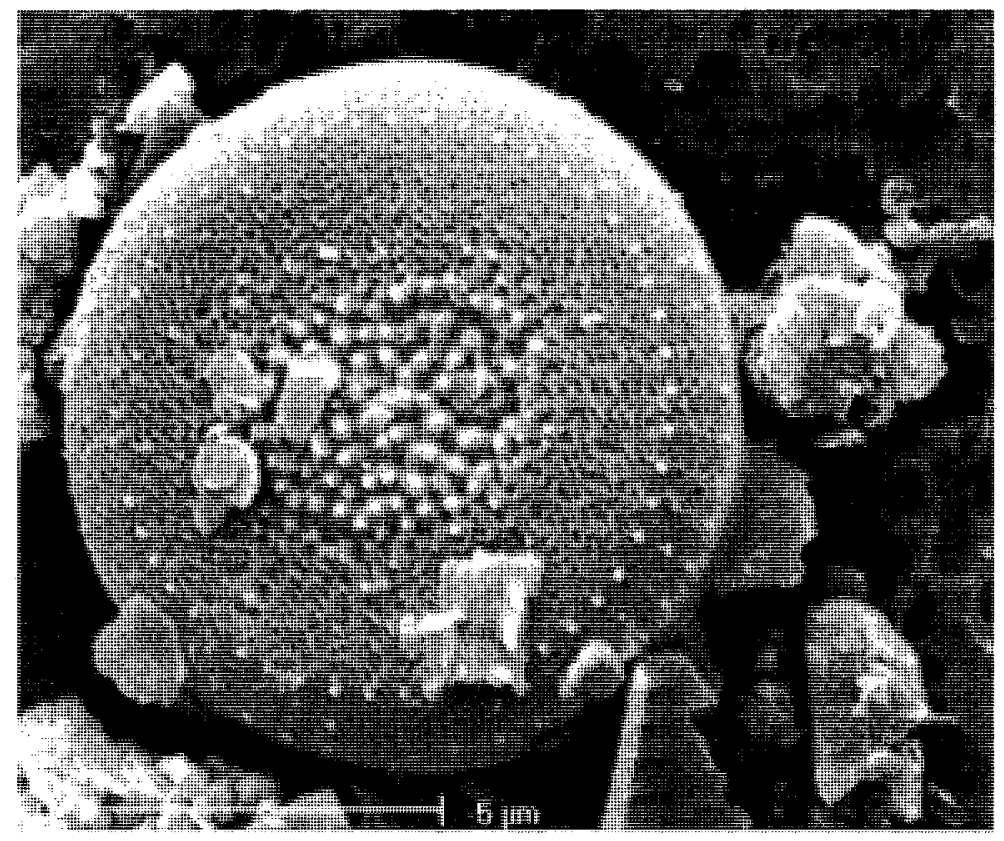

\section{Cycotella comensis \\ Core Depth: $1 \mathrm{~cm}$}

Length: $9.32 \mu \mathrm{m}$; Width: $10.1 \mu \mathrm{m}$

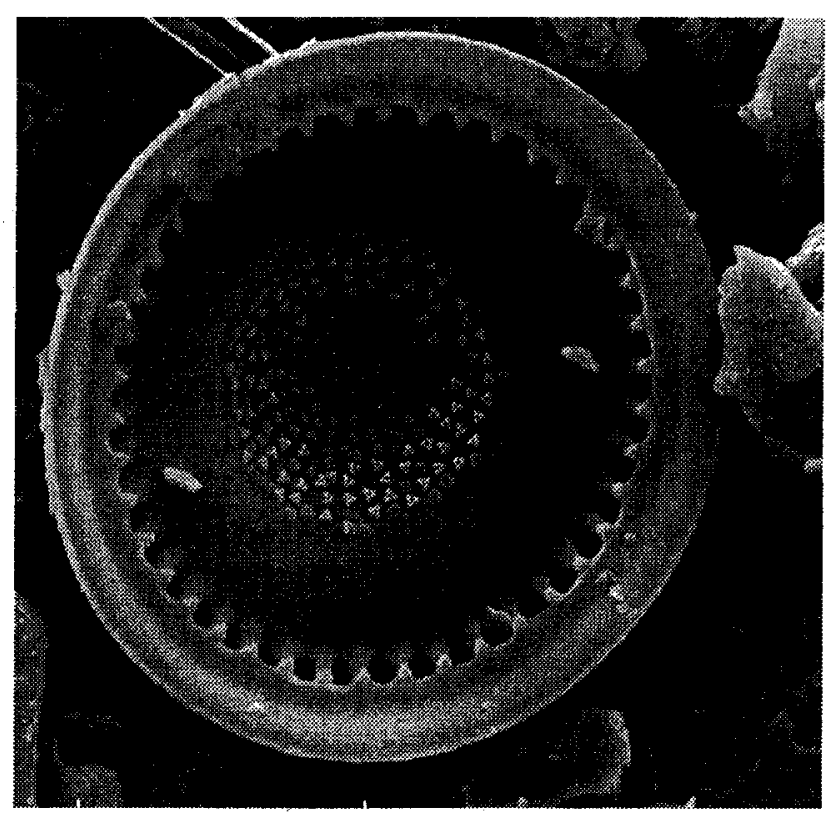

\section{Cyclotella bodanica \\ Core Depth: $1 \mathrm{~cm}$}

Length: $23.5 \mu \mathrm{m}$; Width: $25.5 \mu \mathrm{m}$ 


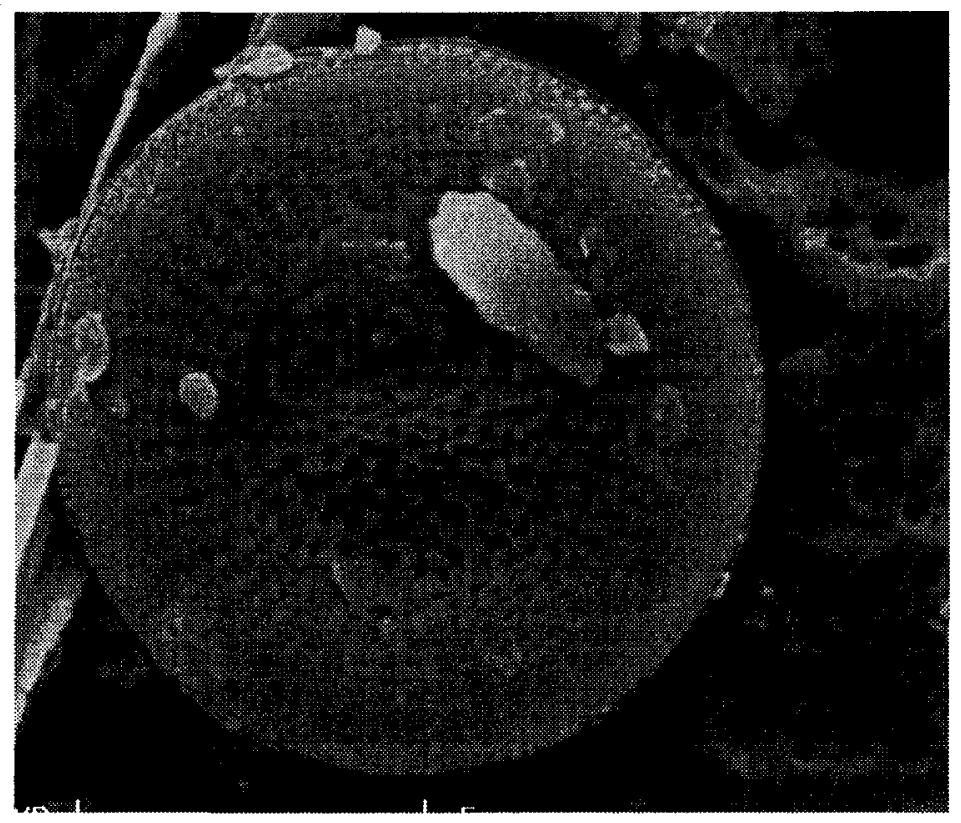

\section{Cyclotella michiganiana}

Core Depth: $1 \mathrm{~cm}$

Length: $10.2 \mu \mathrm{m}$; Width: $10.7 \mu \mathrm{m}$

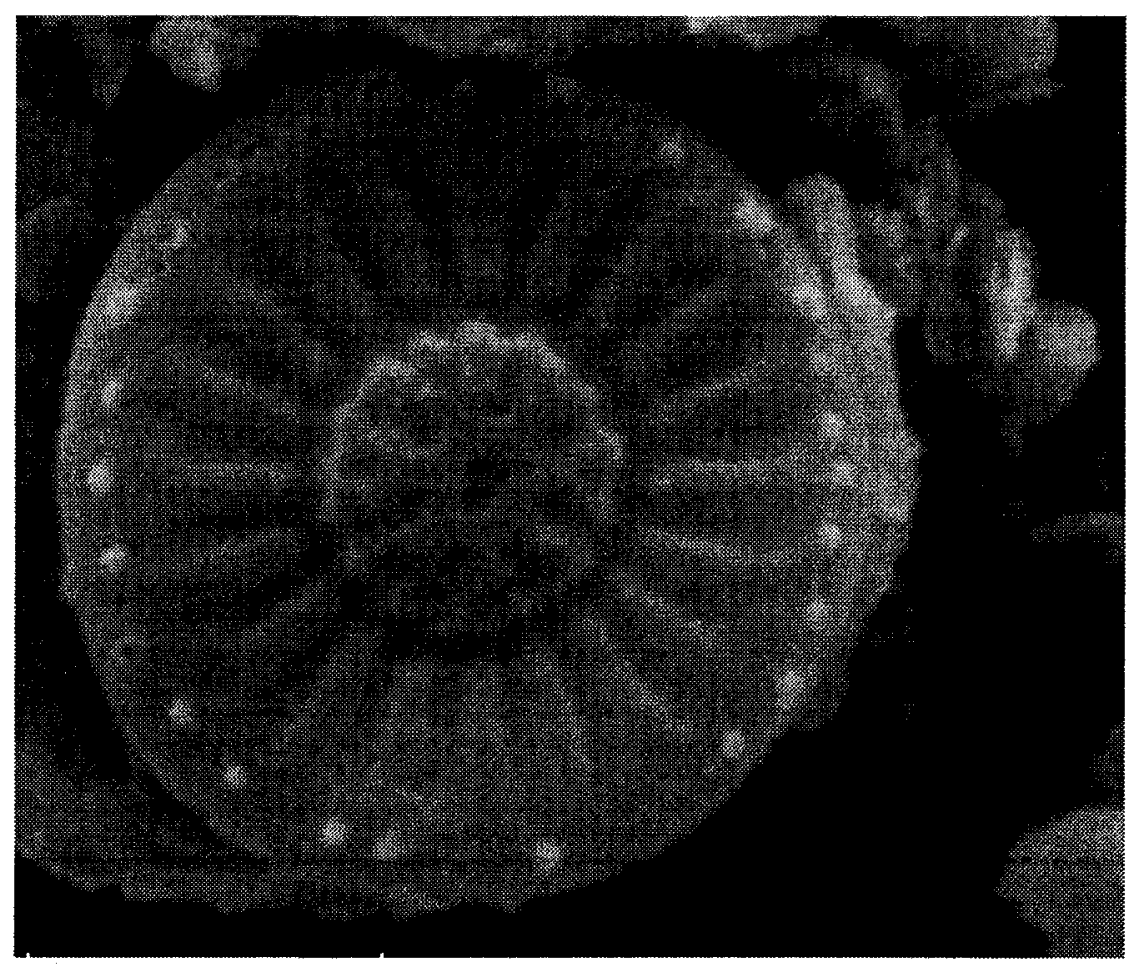

Cyclotella stelligera

Core Depth: $25 \mathrm{~cm}$

Length: $4.58 \mu \mathrm{m}$; Width: $4.93 \mu \mathrm{m}$ 


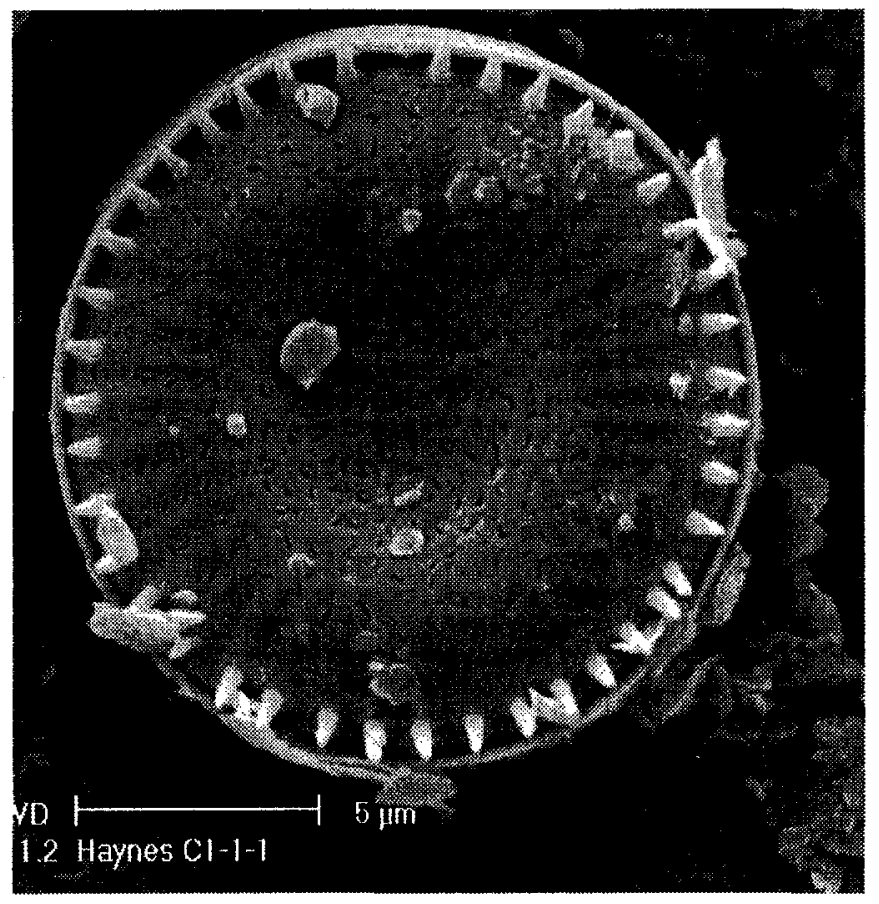

Stephanodiscus medius

Core Depth: $1 \mathrm{~cm}$

Length: $14.3 \mu \mathrm{m}$; Width: $14.6 \mu \mathrm{m}$

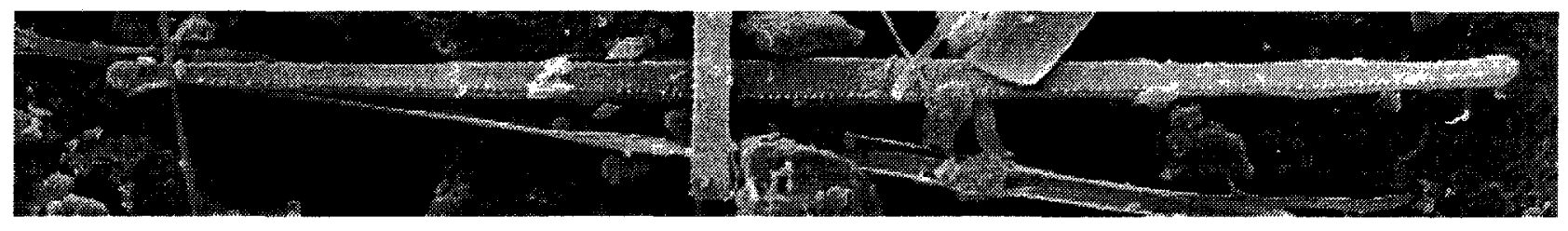

Fragilaria nanana

Core Depth: $1 \mathrm{~cm}$

Length: $69.8 \mu \mathrm{m}$; Width: $2.36 \mu \mathrm{m}$ 


\section{Appendix 7. Sediment core x-ray images: Haynes Lake, Ontario}

Note: The images below are those not included within the text. The top direction is all of these images is to the left.

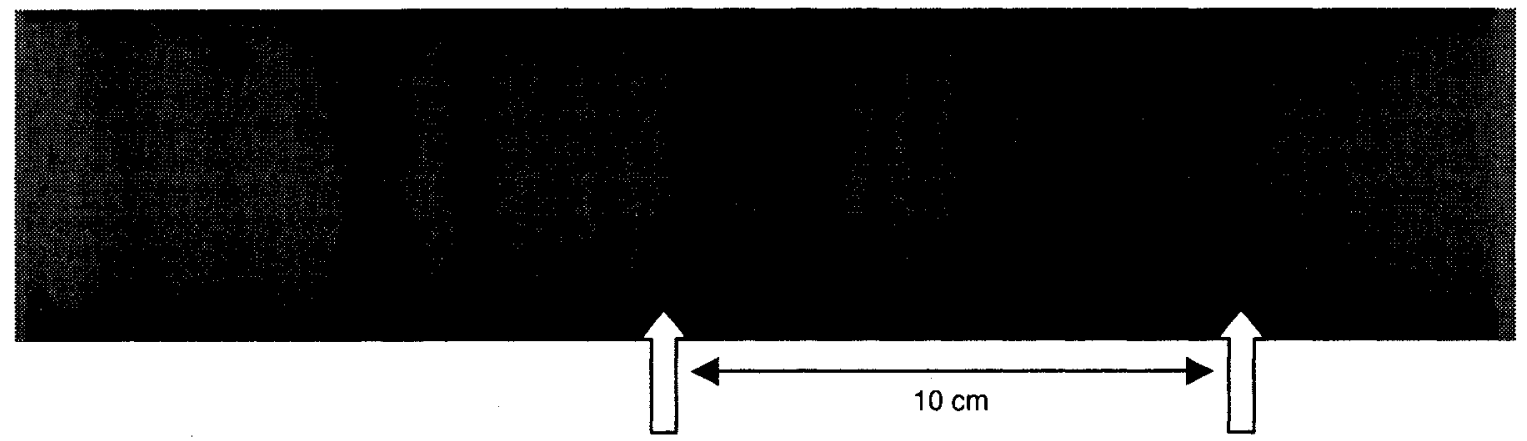

Haynes Lake Core HYC1-1: $34 \mathrm{~cm}-54 \mathrm{~cm}$ depth

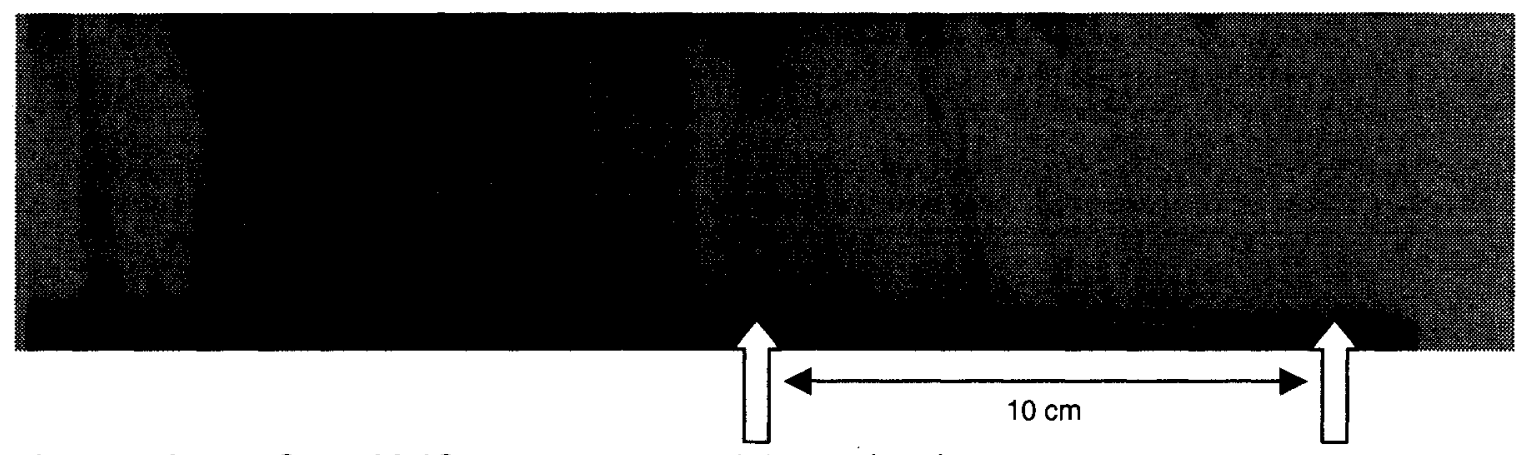

Haynes Lake Core HYC1-1: $74 \mathrm{~cm}-94 \mathrm{~cm}$ depth 


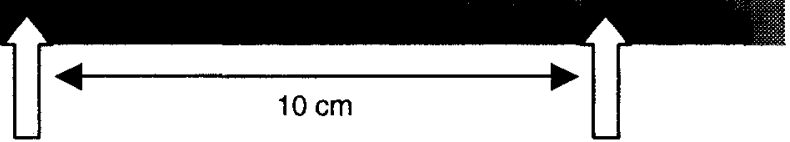

Haynes Lake Core 1-2: $95 \mathrm{~cm}-114 \mathrm{~cm}$ core depth

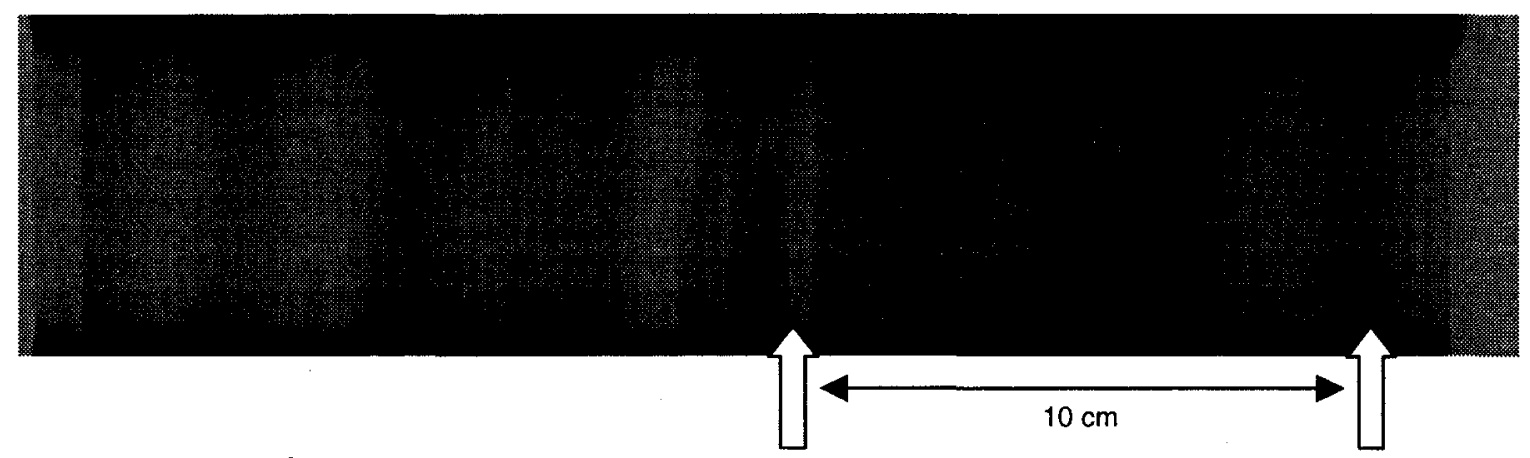

Haynes Lake Core HYC1-2: 153 - $173 \mathrm{~cm}$ core depth

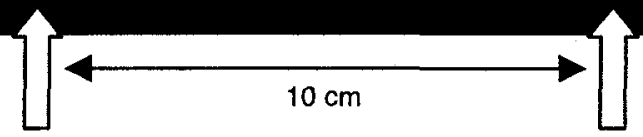

Haynes Lake Core HYC1-2: 173 cm $-188.5 \mathrm{~cm}$ 


\section{Appendix 8. Diatom percent abundance data: Teapot Lake, Ontario}

\begin{tabular}{|c|c|c|c|c|c|c|c|}
\hline \multicolumn{8}{|c|}{ Diatom percent abundance: Teapot Lake, Ontario } \\
\hline \multirow[t]{2}{*}{ Taxon } & \multicolumn{7}{|c|}{ Core Depth } \\
\hline & $\overline{1 \mathrm{~cm}}$ & $2 \mathrm{~cm}$ & $5 \mathrm{~cm}$ & $7 \mathrm{~cm}$ & $8 \mathrm{~cm}$ & $10 \mathrm{~cm}$ & $12 \mathrm{~cm}$ \\
\hline Achnanthes minutissimum & 1.5692 & 3.2653 & 5.5021 & 5.0824 & 2.4355 & 6.8831 & 4.5205 \\
\hline Achnanthes petersenii & 0.0000 & 2.9314 & 0.4910 & 0.0000 & 5.4565 & 2.2183 & 0.0000 \\
\hline Aulacoseira ambigua & 0.2853 & 0.4082 & 1.3755 & 1.6484 & 1.4327 & 0.0000 & 2.1918 \\
\hline Encyonema cesatii & 0.0000 & 0.0000 & 0.0000 & 0.2747 & 0.0000 & 0.0000 & 0.0000 \\
\hline Cymbella cistula & 0.0000 & 0.0000 & 0.0000 & 0.0000 & 0.0000 & 0.0000 & 0.0000 \\
\hline Encyonema minuta & 5.5635 & 2.1769 & 1.5131 & 2.3352 & 3.4384 & 2.3377 & 3.1507 \\
\hline Encyonema silesiacum & 3.4237 & 1.2245 & 4.2641 & 2.1978 & 2.4355 & 1.4286 & 1.7808 \\
\hline Cocconeis euglyta & 0.0000 & 0.0000 & 0.0000 & 0.0000 & 0.0000 & 0.0000 & 0.0000 \\
\hline Cyclotella atomus & 0.1427 & 0.1361 & 0.0000 & 0.0000 & 0.0000 & 0.0000 & 0.0000 \\
\hline Cyclotella comensis & 0.2853 & 0.0000 & 0.0000 & 0.0000 & 0.0000 & 0.0000 & 0.0000 \\
\hline C. michiganiana & 0.5706 & 0.4082 & 0.1376 & 0.5495 & 0.4298 & 0.2597 & 0.0000 \\
\hline Cyclotella stelligera & 0.7133 & 0.2721 & 0.1376 & 0.0000 & 0.0000 & 0.0000 & 0.0000 \\
\hline Eunotia flexuosa & 7.2753 & 12.7891 & 6.4649 & 8.9286 & 7.4499 & 5.1948 & 4.2466 \\
\hline E. intermedia & 6.8474 & 9.1156 & 6.3274 & 5.3571 & 3.4384 & 3.6364 & 4.2466 \\
\hline E. praerupta form 1 & 0.1427 & 0.4082 & 0.2751 & 0.6868 & 1.5759 & 0.2597 & 1.3699 \\
\hline Eunotia diadema & 0.5706 & 0.8163 & 1.2380 & 1.7857 & 2.2923 & 0.7792 & 0.6849 \\
\hline Fragilaria brevistriata & 0.0000 & 0.0000 & 0.0000 & 0.0000 & 0.0000 & 0.0000 & 0.0000 \\
\hline Frag. cap. var. cap. & 2.4251 & 0.6803 & 2.7510 & 5.4945 & 2.2923 & 12.7273 & 8.6301 \\
\hline Frag. cap. var. mesolepta & 0.1427 & 0.2721 & 0.5502 & 0.6868 & 0.8596 & 0.0000 & 0.8219 \\
\hline Frag. capucina v. rumpens & 0.0000 & 0.0000 & 0.0000 & 0.0000 & 0.0000 & 0.0000 & 0.0000 \\
\hline Staurosira construens & 0.0000 & 0.0000 & 0.1376 & 0.0000 & 0.0000 & 0.0000 & 0.0000 \\
\hline S. construens v. venter & 0.0000 & 0.0000 & 0.0000 & 0.5495 & 0.1433 & 0.0000 & 0.0000 \\
\hline Fragilaria leptostauron & 0.0000 & 0.0000 & 0.0000 & 0.4121 & 0.0000 & 0.0000 & 0.0000 \\
\hline Fragilaria nanana & 0.4280 & 0.8163 & 1.3755 & 1.0989 & 1.1461 & 0.0000 & 1.6438 \\
\hline Fragilaria pinnata & 0.0000 & 0.0000 & 0.2751 & 0.1374 & 0.0000 & 0.0000 & 0.0000 \\
\hline Fragilaria tenera & 29.5292 & 24.6259 & 17.3315 & 18.6813 & 20.3438 & 14.0260 & 19.7260 \\
\hline F. ulna and arcus & 0.0000 & 0.0000 & 0.0000 & 0.0000 & 0.0000 & 0.0000 & 0.0000 \\
\hline Cf. G. acuminatum & 0.0000 & 0.1361 & 0.1376 & 0.4121 & 0.8596 & 0.6494 & 0.5479 \\
\hline Gomphonema micropus & 0.0000 & 0.0000 & 0.0000 & 0.0000 & 0.0000 & 0.0000 & 0.0000 \\
\hline Gomphonema augur & 0.0000 & 0.0000 & 0.0000 & 0.1374 & 0.4298 & 0.2597 & 0.1370 \\
\hline G. angustatumgracileaffine & 0.0000 & 0.0000 & 0.0000 & 0.0000 & 0.0000 & 0.0000 & 0.0000 \\
\hline G. truncatumcapitatum+sp7 & 0.0000 & 0.0000 & 0.0000 & 0.0000 & 0.0000 & 0.0000 & 0.0000 \\
\hline Nitzschia sp6 & 0.0000 & 0.1361 & 0.0000 & 0.0000 & 0.0000 & 0.0000 & 0.0000 \\
\hline Meridion circulare Fm1 & 0.0000 & 0.0000 & 0.0000 & 0.0000 & 0.0000 & 0.0000 & 0.0000 \\
\hline Navicula sp3 & 0.0000 & 0.0000 & 0.0000 & 0.1374 & 0.0000 & 0.0000 & 0.0000 \\
\hline Naviculacryptocephala & 0.1427 & 1.2245 & 1.2380 & 1.5110 & 0.5731 & 0.2597 & 0.5479 \\
\hline Navicula cryptotonella & 0.8559 & 0.2721 & 0.1376 & 0.4121 & 0.4298 & 0.0000 & 0.6849 \\
\hline Cf. Eolimna minima & 2.5678 & 2.4490 & 4.4017 & 4.5330 & 5.8739 & 3.3766 & 6.1644 \\
\hline Navicula pseudoventralis & 0.0000 & 0.0000 & 0.4127 & 0.0000 & 0.4298 & 0.0000 & 0.0000 \\
\hline Sellaphora pupula & 0.1427 & 0.1361 & 0.1376 & 0.0000 & 0.0000 & 0.1299 & 0.0000 \\
\hline Navicula radiosa & 4.1369 & 4.4898 & 2.4759 & 1.3736 & 3.1519 & 2.8571 & 1.2329 \\
\hline Nitzschia sp4 & 1.7118 & 1.9048 & 2.0633 & 3.8462 & 2.0057 & 1.5584 & 1.0959 \\
\hline Nitzschia gracilis & 0.9986 & 0.0000 & 0.1376 & 0.0000 & 3.2951 & 4.6753 & 4.9315 \\
\hline Pinnularia subanglica & 1.2839 & 0.4082 & 0.6878 & 0.0000 & 0.5731 & 0.3896 & 0.2740 \\
\hline Pinnularia sp4 & 0.0000 & 0.0000 & 0.0000 & 0.1374 & 0.2865 & 0.0000 & 0.0000 \\
\hline Pinnularia viridis & 0.0000 & 0.0000 & 0.0000 & 0.0000 & 0.0000 & 0.0000 & 0.0000 \\
\hline Stauroneis gracilis & 0.1427 & 0.1361 & 0.0000 & 0.0000 & 0.8596 & 0.0000 & 0.0000 \\
\hline Stauroneis sp2 & 0.0000 & 0.0000 & 0.0000 & 0.0000 & 0.0000 & 0.0000 & 0.0000 \\
\hline Stephanodiscus medius & 0.0000 & 0.0000 & 0.0000 & 0.2747 & 0.0000 & 0.0000 & 0.1370 \\
\hline Surirella linearis & 0.0000 & 0.0000 & 0.0000 & 0.0000 & 0.0000 & 0.0000 & 0.0000 \\
\hline T. flocculosa v. 4 & 1.5692 & 2.3129 & 4.9519 & 2.6099 & 3.1519 & 2.8571 & 3.6986 \\
\hline Taballeria fenestrata & 0.1427 & 0.6803 & 0.1376 & 0.9615 & 0.4298 & 0.6494 & 0.4110 \\
\hline Achnanthes $\mathrm{sp}$ & 0.0000 & 2.0690 & 0.0000 & 0.0000 & 9.2534 & 8.9123 & 0.0000 \\
\hline
\end{tabular}




\begin{tabular}{|c|c|c|c|c|c|c|c|}
\hline \multicolumn{8}{|c|}{ Diatom percent abundance: Teapot Lake, Ontario } \\
\hline \multirow[t]{2}{*}{ Taxon } & \multicolumn{7}{|c|}{ Core Depth } \\
\hline & $1 \mathrm{~cm}$ & $2 \mathrm{~cm}$ & $5 \mathrm{~cm}$ & $7 \mathrm{~cm}$ & $8 \mathrm{~cm}$ & $10 \mathrm{~cm}$ & $12 \mathrm{~cm}$ \\
\hline A. exigua & 0.0000 & 0.0000 & 0.0000 & 0.0000 & 0.0000 & 0.0000 & 0.0000 \\
\hline A. minut. v. scotica & 0.1427 & 0.0000 & 0.0000 & 0.0000 & 0.0000 & 0.0000 & 0.0000 \\
\hline Aulacoseira islandica & 1.2839 & 1.3605 & 1.6506 & 0.6868 & 1.1461 & 4.4156 & 0.4110 \\
\hline Eunotia sp1 & 0.1427 & 0.4082 & 0.0000 & 0.0000 & 0.0000 & 0.7792 & 0.0000 \\
\hline Eunotia sp2 & 0.1427 & 0.0000 & 0.0000 & 0.0000 & 0.0000 & 0.0000 & 0.0000 \\
\hline Eunotia incisa & 4.8502 & 3.6735 & 3.7139 & 1.5110 & 6.3037 & 3.6364 & 4.5205 \\
\hline E. monodon total & 0.0000 & 0.3559 & 0.7117 & 0.0000 & 7.1007 & 3.5296 & 0.0000 \\
\hline E. paludosa & 1.1412 & 1.9048 & 1.1004 & 1.0989 & 0.1433 & 1.1688 & 0.5479 \\
\hline Fragilaria sp1 & 0.7133 & 0.0000 & 0.2751 & 0.0000 & 0.0000 & 0.0000 & 0.0000 \\
\hline Fragilaria sp2 & 0.0000 & 0.0000 & 0.0000 & 0.0000 & 0.0000 & 0.7792 & 0.1370 \\
\hline Fragilaria sp3 & 0.0000 & 0.0000 & 0.0000 & 0.0000 & 0.1433 & 0.0000 & 0.0000 \\
\hline Ct. Frag. neoproducta & 0.0000 & 0.0000 & 0.0000 & 0.0000 & 0.0000 & 0.0000 & 0.0000 \\
\hline Fragilaria senedra & 0.0000 & 0.0000 & 0.0000 & 0.0000 & 0.0000 & 0.0000 & 0.0000 \\
\hline Gomphonema sp2 & 0.1427 & 0.2721 & 0.6878 & 0.9615 & 0.0000 & 0.1299 & 0.4110 \\
\hline Gomphonema sp3 & 0.2853 & 0.5442 & 0.2751 & 0.1374 & 0.0000 & 0.0000 & 0.0000 \\
\hline Gomphonema sp4 & 0.4280 & 0.5442 & 0.5502 & 0.1374 & 0.2865 & 0.5195 & 0.2740 \\
\hline Ct. G. acum. v. Turris & 0.1427 & 0.0000 & 0.0000 & 0.0000 & 0.8596 & 0.0000 & 0.0000 \\
\hline G. cymbelliclinum & 0.4280 & 0.8163 & 0.0000 & 0.8242 & 0.5731 & 0.7792 & 0.5479 \\
\hline Gomphonema gracile & 0.0000 & 0.0000 & 0.0000 & 0.0000 & 0.0000 & 0.0000 & 0.0000 \\
\hline Gparvvparv.f.saprophilum & 0.1427 & 0.0000 & 0.0000 & 0.0000 & 0.0000 & 0.0000 & 0.0000 \\
\hline Neidium sp1 & 0.0000 & 0.0000 & 0.0000 & 0.0000 & 0.0000 & 0.0000 & 0.0000 \\
\hline Neidium sp2 & 0.0000 & 0.0000 & 0.0000 & 0.0000 & 0.0000 & 0.2597 & 0.0000 \\
\hline Neidium affine & 0.0000 & 0.4082 & 0.9629 & 0.5495 & 0.5731 & 0.3896 & 0.4110 \\
\hline Nitzschia sp1 & 0.0000 & 0.0000 & 0.0000 & 0.0000 & 0.0000 & 0.0000 & 0.0000 \\
\hline Nitzschia sp2 & 0.2853 & 0.0000 & 0.1376 & 0.0000 & 0.0000 & 0.0000 & 0.0000 \\
\hline Nitzschia sp3 & 0.0000 & 0.0000 & 0.0000 & 0.0000 & 0.0000 & 0.0000 & 0.0000 \\
\hline Nitzschia perminuta SM & 0.0000 & 0.0000 & 0.5502 & 2.1978 & 2.0057 & 0.5195 & 1.9178 \\
\hline Nitzschia perminuta & 2.1398 & 2.7211 & 5.0894 & 3.5714 & 1.0029 & 2.9870 & 0.2740 \\
\hline Nupela neotropica & 0.7133 & 0.6803 & 0.8253 & 1.2363 & 0.2865 & 2.3377 & 2.6027 \\
\hline Pinnularia macilenta & 0.0000 & 0.1361 & 0.2751 & 0.0000 & 0.0000 & 0.2597 & 0.0000 \\
\hline P. nodosa v. robusta & 0.0000 & 0.0000 & 0.0000 & 0.0000 & 0.0000 & 0.0000 & 0.0000 \\
\hline Stauroneis kriegeri & 0.0000 & 0.0000 & 1.2380 & 0.8242 & 0.1433 & 0.2597 & 0.4110 \\
\hline Stenopterobiaintermedia & 1.1412 & 0.5442 & 0.4127 & 0.5495 & 0.0000 & 0.2597 & 0.2740 \\
\hline Nitzschia agnita & 1.4265 & 1.2245 & 3.8514 & 0.9615 & 0.0000 & 0.0000 & 0.0000 \\
\hline Nitzschia sp5 & 0.0000 & 0.0000 & 0.0000 & 0.0000 & 0.4298 & 0.0000 & 0.0000 \\
\hline Pinnularia sp1 & 0.0000 & 0.0000 & 0.0000 & 0.0000 & 0.0000 & 0.0000 & 0.0000 \\
\hline Achnanthes lanc.lanc. & 0.0000 & 0.0000 & 0.0000 & 0.0000 & 0.0000 & 0.0000 & 0.0000 \\
\hline Meridion sp1 & 0.0000 & 0.0000 & 0.0000 & 0.0000 & 0.0000 & 0.0000 & 0.0000 \\
\hline Gomphonema sp5 & 0.0000 & 0.0000 & 0.0000 & 0.0000 & 0.0000 & 0.0000 & 0.0000 \\
\hline Achnanthes saprophila & 0.1427 & 0.0000 & 0.0000 & 0.0000 & 0.0000 & 0.0000 & 0.0000 \\
\hline Fragilaria sp4 & 0.0000 & 0.1361 & 0.1376 & 0.0000 & 0.0000 & 0.0000 & 0.0000 \\
\hline Pinnularia sp2 & 0.0000 & 0.0000 & 0.1376 & 0.5495 & 0.0000 & 0.0000 & 0.0000 \\
\hline Pinnularia sp3 & 0.0000 & 0.0000 & 0.1376 & 0.0000 & 0.0000 & 0.0000 & 0.0000 \\
\hline Achnanthes holsatica & 0.0000 & 0.0000 & 0.1376 & 0.0000 & 0.0000 & 0.0000 & 0.0000 \\
\hline Pinnularia sp5 & 0.0000 & 0.0000 & 0.0000 & 0.0000 & 0.1433 & 0.0000 & 0.2740 \\
\hline Nitzschia sp7 & 0.0000 & 0.0000 & 0.0000 & 0.0000 & 0.0000 & 0.0000 & 1.9178 \\
\hline Stephanodiscus sp1 & 0.0000 & 0.0000 & 0.0000 & 0.0000 & 0.0000 & 0.0000 & 0.2740 \\
\hline Brachysira microcephala & 0.0000 & 0.0000 & 0.0000 & 0.0000 & 0.7163 & 0.0000 & 0.0000 \\
\hline $\begin{array}{l}\text { Pinnularia sp6 } \\
\text { Pin }\end{array}$ & 0.0000 & 0.0000 & 0.0000 & 0.0000 & 0.0000 & 0.0000 & 0.0000 \\
\hline Cymbella sp1 & 0.0000 & 0.0000 & 0.0000 & 0.0000 & 0.0000 & 0.0000 & 0.0000 \\
\hline Gomphonema sp 6 & 0.0000 & 0.0000 & 0.0000 & 0.0000 & 0.0000 & 0.0000 & 0.0000 \\
\hline Navicula chiarae & 0.0000 & 0.0000 & 0.0000 & 0.0000 & 0.0000 & 0.0000 & 0.0000 \\
\hline Denticula sp1 & 0.0000 & 0.0000 & 0.0000 & 0.0000 & 1.1461 & 0.0000 & 0.5479 \\
\hline Gomphonema sp8 & 0.0000 & 0.0000 & 0.0000 & 0.0000 & 0.0000 & 0.0000 & 0.0000 \\
\hline Brachysira sp1 & 0.0000 & 0.0000 & 0.0000 & 0.0000 & 0.0000 & 0.0000 & 0.1370 \\
\hline Navicula sp4 & 0.0000 & 0.0000 & 0.0000 & 0.0000 & 0.0000 & 0.0000 & 0.0000 \\
\hline
\end{tabular}




\begin{tabular}{|c|c|c|c|c|c|c|c|}
\hline & atom perc & abundar & e: Teapot & ake, Onta & & & \\
\hline Taxon & & & & re Depth & & & \\
\hline & $15 \mathrm{~cm}$ & $20 \mathrm{~cm}$ & $25 \mathrm{~cm}$ & $30 \mathrm{~cm}$ & $40 \mathrm{~cm}$ & $50 \mathrm{~cm}$ & $60 \mathrm{~cm}$ \\
\hline Achnanthes minutissimum & 1.8692 & 2.1333 & 3.2967 & 4.4190 & 5.3333 & 0.0000 & 0.1570 \\
\hline Achnanthes petersenii & 0.3273 & 0.0000 & 0.0000 & 0.0000 & 13.0290 & 6.8652 & 1.0141 \\
\hline Aulacoseira ambigua & 1.0903 & 2.1333 & 1.7857 & 1.1457 & 0.0000 & 0.0000 & 0.1570 \\
\hline Encyonema cesatii & 0.0000 & 0.0000 & 0.0000 & 0.4910 & 0.0000 & 0.0000 & 0.0000 \\
\hline Cymbella cistula & 0.0000 & 0.0000 & 0.0000 & 0.0000 & 0.0000 & 0.0000 & 0.0000 \\
\hline Encyonema minuta & 4.5171 & 4.5333 & 3.9835 & 1.4730 & 1.5000 & 5.8531 & 4.2386 \\
\hline Encyonema silesiacum & 3.1153 & 0.5333 & 1.2363 & 0.9820 & 1.6667 & 0.2491 & 1.5699 \\
\hline Cocconeis euglyta & 0.0000 & 0.0000 & 0.0000 & 0.0000 & 0.0000 & 0.0000 & 0.0000 \\
\hline Cyclotella atomus & 0.1558 & 0.0000 & 0.0000 & 0.3273 & 0.0000 & 0.1245 & 0.0000 \\
\hline Cyclotella comensis & 0.0000 & 0.1333 & 0.0000 & 0.0000 & 0.0000 & 0.1245 & 0.0000 \\
\hline C. michiganiana & 0.1558 & 0.0000 & 0.0000 & 0.0000 & 0.0000 & 0.0000 & 0.0000 \\
\hline Cyclotella stelligera & 0.3115 & 0.0000 & 0.0000 & 0.0000 & 0.1667 & 0.0000 & 0.1570 \\
\hline Eunotia flexuosa & 15.4206 & 6.5333 & 6.3187 & 6.7103 & 4.6667 & 9.3400 & 16.6405 \\
\hline E. intermedia & 8.4112 & 3.8667 & 2.6099 & 4.2553 & 3.3333 & 5.8531 & 6.7504 \\
\hline E. praerupta form 1 & 0.4673 & 0.8000 & 0.6868 & 0.3273 & 0.1667 & 0.3736 & 0.4710 \\
\hline Eunotia diadema & 0.9346 & 0.5333 & 0.1374 & 0.0000 & 0.0000 & 0.0000 & 0.0000 \\
\hline Fragilaria brevistriata & 0.0000 & 0.0000 & 0.0000 & 0.0000 & 0.1667 & 0.0000 & 0.0000 \\
\hline Frag. cap. var. cap. & 4.6729 & 8.2667 & 5.3571 & 1.9640 & 3.0000 & 13.5741 & 3.7677 \\
\hline Frag. cap. var. mesolepta & 0.1558 & 0.0000 & 0.2747 & 0.4910 & 0.3333 & 0.1245 & 0.0000 \\
\hline Frag. capucina v, rumpens & 0.0000 & 0.0000 & 0.0000 & 0.0000 & 0.0000 & 0.0000 & 0.0000 \\
\hline Staurosira construens & 0.0000 & 0.0000 & 0.0000 & 0.0000 & 0.0000 & 0.0000 & 0.0000 \\
\hline S. construens $v$. venter & 0.3115 & 0.0000 & 0.0000 & 0.0000 & 0.0000 & 0.0000 & 0.0000 \\
\hline Fragilaria leptostauron & 0.0000 & 0.0000 & 0.0000 & 0.0000 & 0.0000 & 0.0000 & 0.0000 \\
\hline Fragilaria nanana & 0.6231 & 0.8000 & 1.2363 & 1.1457 & 12.3333 & 0.0000 & 0.1570 \\
\hline Fragilaria pinnata & 0.0000 & 0.0000 & 0.0000 & 0.0000 & 0.0000 & 0.0000 & 0.0000 \\
\hline Fragilaria tenera & 21.1838 & 39.2000 & 31.5934 & 43.3715 & 34.3333 & 33.8730 & 28.7284 \\
\hline F. ulna and arcus & 0.0000 & 0.0000 & 0.0000 & 0.0000 & 0.0000 & 0.0000 & 0.0000 \\
\hline Cf. G. acuminatum & 0.7788 & 0.2667 & 1.3736 & 0.6547 & 0.0000 & 0.0000 & 0.1570 \\
\hline Gomphonema micropus & 0.0000 & 0.0000 & 0.0000 & 0.0000 & 0.0000 & 0.0000 & 0.0000 \\
\hline Gomphonema augur & 0.3115 & 0.0000 & 0.0000 & 0.0000 & 0.0000 & 0.0000 & 0.3140 \\
\hline G. angustatumgracileaffine & 0.0000 & 0.0000 & 0.0000 & 0.0000 & 0.0000 & 0.0000 & 0.0000 \\
\hline G. truncatumcapitatum+sp7 & 0.0000 & 0.0000 & 0.0000 & 0.0000 & 0.0000 & 0.0000 & 0.0000 \\
\hline Nitzschia sp6 & 0.0000 & 0.0000 & 0.2747 & 0.0000 & 0.0000 & 0.0000 & 0.1570 \\
\hline Meridion circulare Fm1 & 0.0000 & 0.0000 & 0.0000 & 0.0000 & 0.0000 & 0.4981 & 0.0000 \\
\hline Navicula sp3 & 0.0000 & 0.0000 & 0.0000 & 0.0000 & 0.0000 & 0.0000 & 0.1570 \\
\hline Naviculacryptocephala & 0.9346 & 1.6000 & 1.0989 & 0.3273 & 0.0000 & 0.0000 & 4.7096 \\
\hline Navicula cryptotonella & 0.3115 & 0.2667 & 0.0000 & 0.3273 & 0.6667 & 0.0000 & 1.2559 \\
\hline Cf. Eolimna minima & 1.2461 & 2.4000 & 1.6484 & 1.8003 & 1.0000 & 0.1245 & 0.4710 \\
\hline Navicula pseudoventralis & 0.0000 & 0.0000 & 0.0000 & 0.0000 & 0.0000 & 0.0000 & 0.0000 \\
\hline Sellaphora pupula & 0.0000 & 0.0000 & 0.2747 & 0.0000 & 0.0000 & 0.0000 & 0.0000 \\
\hline Navicula radiosa & 3.5826 & 0.4000 & 2.7473 & 2.2913 & 2.5000 & 10.3362 & 7.3783 \\
\hline Nitzschia sp4 & 0.0000 & 1.0667 & 0.6868 & 1.9640 & 8.6667 & 0.0000 & 0.9419 \\
\hline Nitzschia gracilis & 0.0000 & 0.8000 & 0.0000 & 0.0000 & 1.3333 & 0.9963 & 0.0000 \\
\hline Pinnularia subanglica & 1.4019 & 0.5333 & 0.2747 & 1.8003 & 0.0000 & 0.0000 & 0.0000 \\
\hline Pinnularia sp4 & 0.0000 & 0.0000 & 0.0000 & 0.0000 & 0.0000 & 0.0000 & 0.0000 \\
\hline Pinnularia viridis & 0.0000 & 0.0000 & 0.0000 & 0.0000 & 0.0000 & 0.0000 & 0.0000 \\
\hline Stauroneis gracilis & 0.0000 & 0.0000 & 0.2747 & 0.0000 & 0.3333 & 0.0000 & 0.1570 \\
\hline Stauroneis sp2 & 0.0000 & 0.0000 & 0.0000 & 0.0000 & 0.0000 & 0.0000 & 0.0000 \\
\hline Stephanodiscus medius & 0.0000 & 0.0000 & 0.0000 & 0.0000 & 0.0000 & 0.0000 & 0.0000 \\
\hline Surirella linearis & 0.0000 & 0.0000 & 0.0000 & 0.0000 & 0.0000 & 0.0000 & 0.0000 \\
\hline T. flocculosa v. 4 & 0.4673 & 0.4000 & 0.8242 & 1.1457 & 1.0000 & 0.3736 & 0.1570 \\
\hline Taballeria fenestrata & 0.4673 & 0.4000 & 0.2747 & 0.3273 & 0.8333 & 0.3736 & 0.7849 \\
\hline Achnanthes sp & 0.2787 & 0.2853 & 1.1163 & 1.1229 & 26.5294 & 22.2904 & 0.8259 \\
\hline A. exigua & 0.0000 & 0.0000 & 0.0000 & 0.0000 & 0.0000 & 0.0000 & 0.1570 \\
\hline A. minut. v. scotica & 0.0000 & 0.0000 & 0.0000 & 0.0000 & 0.0000 & 0.0000 & 0.0000 \\
\hline Aulacoseira islandica & 2.0249 & 1.0667 & 0.2747 & 0.3273 & 0.1667 & 0.1245 & 0.0000 \\
\hline Eunotia sp1 & 0.1558 & 0.0000 & 0.1374 & 0.0000 & 0.0000 & 0.0000 & 0.0000 \\
\hline Eunotia sp2 & 0.0000 & 0.0000 & 0.0000 & 0.0000 & 0.0000 & 0.2491 & 0.0000 \\
\hline
\end{tabular}




\begin{tabular}{|c|c|c|c|c|c|c|c|}
\hline \multicolumn{8}{|c|}{ Diatom percent abundance: Teapot Lake, Ontario } \\
\hline \multirow[t]{2}{*}{ Taxon } & \multicolumn{7}{|c|}{ Core Depth } \\
\hline & $15 \mathrm{~cm}$ & $20 \mathrm{~cm}$ & $25 \mathrm{~cm}$ & $30 \mathrm{~cm}$ & $40 \mathrm{~cm}$ & $50 \mathrm{~cm}$ & $60 \mathrm{~cm}$ \\
\hline Eunotia incisa & 3.4268 & 2.2667 & 2.6099 & 3.1097 & 1.3333 & 3.3624 & 0.7849 \\
\hline E. monodon total & 0.0000 & 0.0000 & 0.0000 & 0.0000 & 25.9109 & 2.2220 & 1.4235 \\
\hline E. paludosa & 1.5576 & 0.6667 & 1.2363 & 0.9820 & 0.1667 & 2.1171 & 1.7268 \\
\hline Fragilaria sp1 & 0.0000 & 0.0000 & 0.0000 & 0.0000 & 0.0000 & 0.0000 & 0.0000 \\
\hline Fragilaria sp2 & 0.0000 & 0.0000 & 0.0000 & 0.0000 & 0.0000 & 0.1245 & 0.0000 \\
\hline Fragilaria sp3 & 0.0000 & 0.0000 & 0.0000 & 0.0000 & 0.0000 & 0.2491 & 0.0000 \\
\hline Cf. Frag. neoproducta & 0.0000 & 0.0000 & 0.0000 & 0.0000 & 0.0000 & 0.0000 & 0.0000 \\
\hline Fragilaria senedra & 0.0000 & 0.0000 & 0.0000 & 0.0000 & 0.0000 & 0.0000 & 0.0000 \\
\hline Gomphonema sp2 & 0.7788 & 0.0000 & 0.1374 & 0.0000 & 0.0000 & 0.0000 & 0.0000 \\
\hline Gomphonema sp3 & 0.3115 & 0.1333 & 0.5495 & 0.0000 & 0.0000 & 0.0000 & 0.7849 \\
\hline Gomphonema sp4 & 0.0000 & 0.0000 & 0.2747 & 0.6547 & 0.0000 & 0.2491 & 0.7849 \\
\hline Cf. G. acum. v. Turris & 0.4673 & 0.0000 & 0.1374 & 0.0000 & 0.0000 & 0.2491 & 0.0000 \\
\hline G. cymbelliclinum & 0.3115 & 0.9333 & 0.5495 & 0.0000 & 0.0000 & 0.2491 & 0.0000 \\
\hline Gomphonema gracile & 0.0000 & 0.0000 & 0.0000 & 0.0000 & 0.0000 & 0.0000 & 0.0000 \\
\hline Gparvvparv.f.saprophilum & 0.0000 & 0.0000 & 0.0000 & 0.0000 & 0.0000 & 0.0000 & 0.0000 \\
\hline Neidium sp1 & 0.0000 & 0.0000 & 0.0000 & 0.0000 & 0.0000 & 0.0000 & 0.0000 \\
\hline Neidium sp2 & 0.0000 & 0.1333 & 0.0000 & 0.1637 & 0.0000 & 0.0000 & 0.0000 \\
\hline Neidium affine & 0.9346 & 0.2667 & 0.4121 & 0.0000 & 0.0000 & 0.0000 & 0.1570 \\
\hline Nitzschia sp1 & 0.0000 & 0.0000 & 0.0000 & 0.0000 & 0.0000 & 0.0000 & 0.0000 \\
\hline Nitzschia sp2 & 0.0000 & 0.0000 & 0.0000 & 0.0000 & 0.0000 & 0.0000 & 0.0000 \\
\hline Nitzschia sp3 & 0.0000 & 0.0000 & 0.0000 & 0.0000 & 0.0000 & 0.0000 & 0.0000 \\
\hline Nitzschia perminuta SM & 0.4673 & 2.2667 & 2.6099 & 2.1277 & 0.6667 & 0.0000 & 0.3140 \\
\hline Nitzschia perminuta & 2.9595 & 3.8667 & 10.3022 & 4.4190 & 3.3333 & 0.2491 & 2.6688 \\
\hline Nupela neotropica & 0.6231 & 0.0000 & 0.8242 & 0.3273 & 0.1667 & 0.0000 & 0.3140 \\
\hline Pinnularia macilenta & 0.0000 & 0.0000 & 0.0000 & 0.0000 & 0.0000 & 0.0000 & 0.3140 \\
\hline P. nodosa v. robusta & 0.0000 & 0.0000 & 0.0000 & 0.0000 & 0.0000 & 0.0000 & 0.0000 \\
\hline Stauroneis kriegeri & 0.1558 & 0.0000 & 0.1374 & 0.0000 & 0.1667 & 0.0000 & 0.0000 \\
\hline Stenopterobiaintermedia & 0.0000 & 0.2667 & 0.4121 & 0.1637 & 0.0000 & 0.3736 & 0.1570 \\
\hline Nitzschia agnita & 2.3364 & 1.8667 & 1.5110 & 1.1457 & 0.3333 & 0.0000 & 0.3140 \\
\hline Nitzschia sp5 & 0.0000 & 0.0000 & 0.0000 & 0.0000 & 0.0000 & 0.0000 & 0.0000 \\
\hline Pinnularia sp1 & 0.0000 & 0.0000 & 0.0000 & 0.0000 & 0.0000 & 0.0000 & 0.0000 \\
\hline Achnanthes lanc.lanc. & 0.0000 & 0.0000 & 0.0000 & 0.3273 & 0.0000 & 0.0000 & 0.0000 \\
\hline Meridion sp1 & 0.0000 & 0.0000 & 0.2747 & 0.0000 & 0.1667 & 0.0000 & 0.0000 \\
\hline Gomphonema sp5 & 0.0000 & 0.0000 & 0.0000 & 0.0000 & 0.3333 & 0.0000 & 0.0000 \\
\hline Achnanthes saprophila & 0.0000 & 0.0000 & 0.0000 & 0.0000 & 0.0000 & 0.0000 & 0.0000 \\
\hline Fragilaria sp4 & 0.0000 & 0.0000 & 0.0000 & 0.1637 & 0.0000 & 0.0000 & 0.1570 \\
\hline Pinnularia sp2 & 0.1558 & 0.1333 & 0.0000 & 0.0000 & 0.0000 & 0.0000 & 0.0000 \\
\hline Pinnularia sp3 & 0.0000 & 0.0000 & 0.1374 & 0.0000 & 0.0000 & 0.0000 & 0.0000 \\
\hline Achnanthes holsatica & 0.0000 & 0.0000 & 0.0000 & 0.0000 & 0.0000 & 0.0000 & 0.0000 \\
\hline Pinnularia sp5 & 0.0000 & 0.0000 & 0.0000 & 0.1637 & 0.0000 & 0.0000 & 0.0000 \\
\hline Nitzschia sp7 & 0.0000 & 0.0000 & 0.0000 & 0.0000 & 0.0000 & 0.0000 & 0.0000 \\
\hline Stephanodiscus sp1 & 0.0000 & 0.0000 & 0.0000 & 0.0000 & 0.0000 & 0.0000 & 0.0000 \\
\hline Brachysira microcephala & 0.0000 & 0.0000 & 0.0000 & 0.0000 & 0.0000 & 0.0000 & 0.0000 \\
\hline Pinnularia sp6 & 0.0000 & 0.0000 & 0.0000 & 0.0000 & 0.0000 & 0.0000 & 0.0000 \\
\hline Cymbella sp1 & 0.0000 & 0.0000 & 0.0000 & 0.0000 & 0.0000 & 0.0000 & 0.0000 \\
\hline Gomphonema sp6 & 0.0000 & 0.0000 & 0.0000 & 0.0000 & 0.0000 & 0.0000 & 0.0000 \\
\hline Navicula chiarae & 0.0000 & 0.0000 & 0.0000 & 0.0000 & 0.0000 & 0.0000 & 0.0000 \\
\hline Denticula sp1 & 0.0000 & 0.0000 & 0.0000 & 0.0000 & 0.0000 & 0.0000 & 0.0000 \\
\hline Gomphonema sp8 & 0.0000 & 0.0000 & 0.0000 & 0.0000 & 0.0000 & 0.0000 & 0.0000 \\
\hline Brachysira sp1 & 0.0000 & 0.0000 & 0.0000 & 0.0000 & 0.0000 & 0.0000 & 0.0000 \\
\hline Navicula sp4 & 0.0000 & 0.0000 & 0.0000 & 0.0000 & 0.0000 & 0.0000 & 0.0000 \\
\hline
\end{tabular}




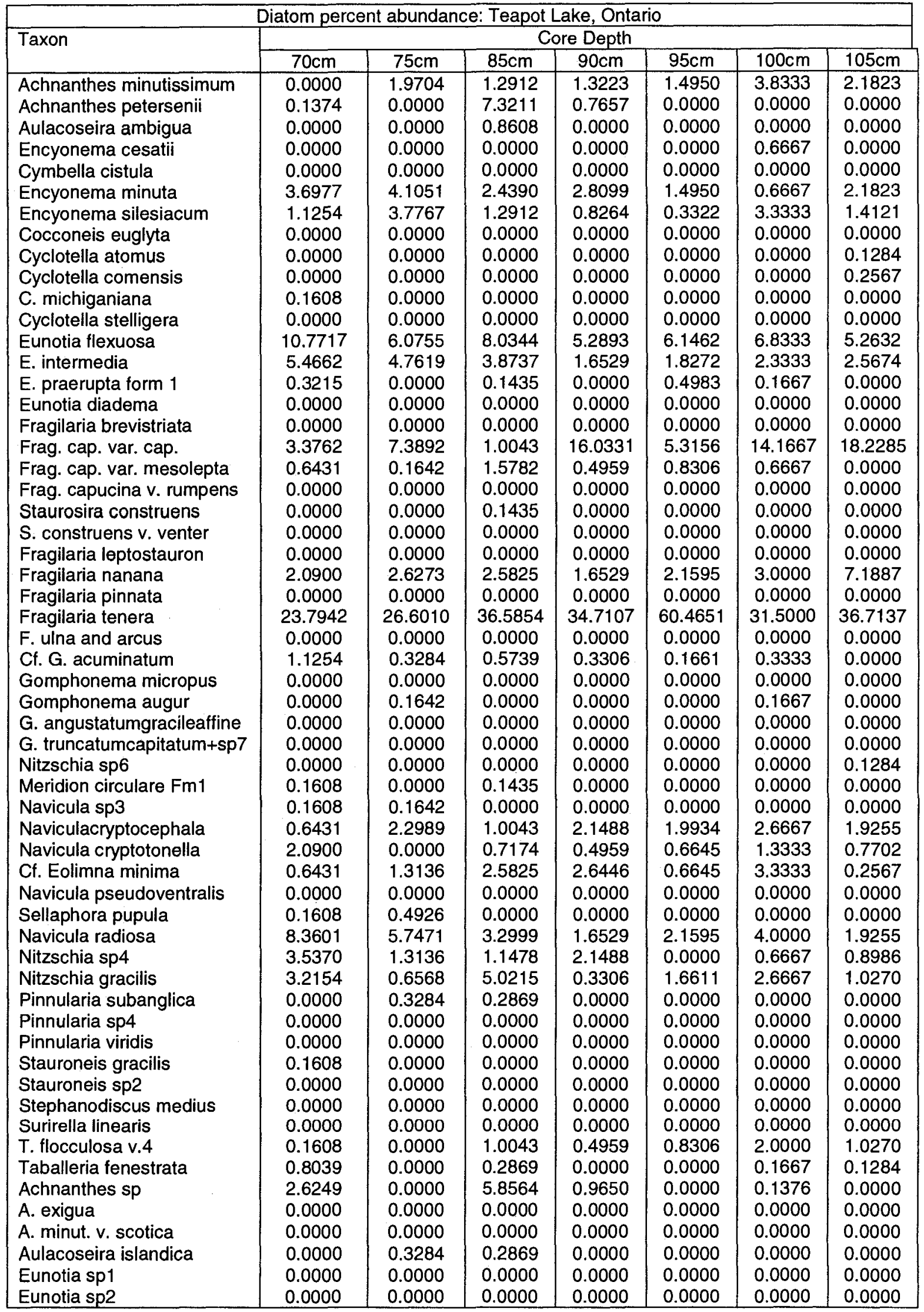




\begin{tabular}{|c|c|c|c|c|c|c|c|}
\hline \multicolumn{8}{|c|}{ Diatom percent abundance: Teapot Lake, Ontario } \\
\hline \multirow[t]{2}{*}{ Taxon } & \multicolumn{7}{|c|}{ Core Depth } \\
\hline & $70 \mathrm{~cm}$ & $75 \mathrm{~cm}$ & $85 \mathrm{~cm}$ & $90 \mathrm{~cm}$ & $95 \mathrm{~cm}$ & $100 \mathrm{~cm}$ & $105 \mathrm{~cm}$ \\
\hline Eunotia incisa & 0.8039 & 0.3284 & 0.7174 & 0.1653 & 0.1661 & 1.0000 & 1.1553 \\
\hline E. monodon total & 0.0000 & 0.0000 & 5.4080 & 0.0000 & 0.0000 & 0.0000 & 0.0000 \\
\hline E. paludosa & 0.9646 & 1.6420 & 0.2869 & 0.4959 & 0.4983 & 0.0000 & 0.0000 \\
\hline Fragilaria sp1 & 0.0000 & 0.9852 & 0.0000 & 0.0000 & 0.0000 & 0.0000 & 0.0000 \\
\hline Fragilaria sp2 & 0.0000 & 0.0000 & 0.0000 & 0.0000 & 0.0000 & 0.0000 & 0.0000 \\
\hline Fragilaria sp3 & 0.0000 & 0.0000 & 0.0000 & 0.0000 & 0.0000 & 0.0000 & 0.0000 \\
\hline Cf. Frag. neoproducta & 0.0000 & 0.0000 & 0.0000 & 0.0000 & 0.0000 & 0.0000 & 0.0000 \\
\hline Fragilaria senedra & 0.0000 & 0.0000 & 0.0000 & 0.0000 & 0.0000 & 0.0000 & 0.0000 \\
\hline Gomphonema sp2 & 0.0000 & 0.4926 & 0.0000 & 0.0000 & 0.0000 & 0.0000 & 0.0000 \\
\hline Gomphonema sp3 & 0.1608 & 0.6568 & 0.0000 & 0.0000 & 0.0000 & 0.0000 & 0.0000 \\
\hline Gomphonema sp4 & 0.0000 & 0.0000 & 0.1435 & 0.0000 & 0.3322 & 0.1667 & 0.0000 \\
\hline Cf. G. acum. v. Turris & 0.0000 & 0.3284 & 0.0000 & 0.0000 & 0.6645 & 0.0000 & 0.0000 \\
\hline G. cymbelliclinum & 0.0000 & 0.6568 & 0.0000 & 0.3306 & 0.0000 & 0.0000 & 0.0000 \\
\hline Gomphonema gracile & 0.0000 & 0.0000 & 0.0000 & 0.0000 & 0.0000 & 0.0000 & 0.0000 \\
\hline Gparvvparv.f.saprophilum & 0.4823 & 0.0000 & 0.0000 & 0.0000 & 0.3322 & 0.0000 & 0.0000 \\
\hline Neidium sp1 & 0.0000 & 0.0000 & 0.0000 & 0.0000 & 0.0000 & 0.0000 & 0.0000 \\
\hline Neidium sp2 & 0.0000 & 0.0000 & 0.0000 & 0.0000 & 0.0000 & 0.0000 & 0.0000 \\
\hline Neidium affine & 0.0000 & 0.0000 & 0.0000 & 0.0000 & 0.0000 & 0.0000 & 0.0000 \\
\hline Nitzschia sp1 & 0.0000 & 0.0000 & 0.0000 & 0.0000 & 0.0000 & 0.0000 & 0.0000 \\
\hline Nitzschia sp2 & 0.0000 & 0.0000 & 0.0000 & 0.0000 & 0.0000 & 0.0000 & 0.0000 \\
\hline Nitzschia sp3 & 0.0000 & 0.0000 & 0.0000 & 0.0000 & 0.0000 & 0.0000 & 0.0000 \\
\hline Nitzschia perminuta SM & 0.1608 & 0.0000 & 0.2869 & 0.8264 & 0.3322 & 3.3333 & 0.5135 \\
\hline Nitzschia perminuta & 1.4469 & 4.2693 & 2.8694 & 5.9504 & 0.3322 & 1.8333 & 1.2837 \\
\hline Nupela neotropica & 0.1608 & 0.8210 & 0.2869 & 0.0000 & 1.3289 & 1.6667 & 0.7702 \\
\hline Pinnularia macilenta & 0.0000 & 0.0000 & 0.0000 & 0.3306 & 0.0000 & 0.0000 & 0.1284 \\
\hline P. nodosa v. robusta & 0.0000 & 0.0000 & 0.0000 & 0.0000 & 0.0000 & 0.0000 & 0.0000 \\
\hline Stauroneis kriegeri & 0.4823 & 0.0000 & 0.0000 & 0.0000 & 0.0000 & 0.0000 & 0.0000 \\
\hline Stenopterobiaintermedia & 0.4823 & 1.1494 & 0.0000 & 0.3306 & 0.1661 & 0.3333 & 0.2567 \\
\hline Nitzschia agnita & 0.0000 & 1.8062 & 0.0000 & 0.8264 & 0.0000 & 0.0000 & 0.0000 \\
\hline Nitzschia sp5 & 0.0000 & 0.8210 & 0.0000 & 0.0000 & 0.0000 & 0.0000 & 0.0000 \\
\hline Pinnularia sp1 & 0.0000 & 0.3284 & 0.0000 & 0.0000 & 0.0000 & 0.0000 & 0.0000 \\
\hline Achnanthes lanc.lanc. & 0.0000 & 0.0000 & 0.0000 & 0.0000 & 0.0000 & 0.0000 & 0.0000 \\
\hline Meridion sp1 & 0.0000 & 0.0000 & 0.0000 & 0.0000 & 0.0000 & 0.0000 & 0.0000 \\
\hline Gomphonema sp5 & 0.0000 & 0.0000 & 0.0000 & 0.0000 & 0.0000 & 0.5000 & 0.2567 \\
\hline Achnanthes saprophila & 0.0000 & 0.0000 & 0.0000 & 0.0000 & 0.0000 & 0.0000 & 0.0000 \\
\hline Fragilaria sp4 & 0.0000 & 0.0000 & 0.0000 & 0.0000 & 0.0000 & 0.0000 & 0.0000 \\
\hline Pinnularia sp2 & 0.1608 & 0.0000 & 0.0000 & 0.0000 & 0.0000 & 0.0000 & 0.0000 \\
\hline Pinnularia sp3 & 0.0000 & 0.0000 & 0.0000 & 0.0000 & 0.0000 & 0.0000 & 0.0000 \\
\hline Achnanthes holsatica & 0.0000 & 0.0000 & 0.0000 & 0.0000 & 0.0000 & 0.0000 & 0.0000 \\
\hline Pinnularia sp5 & 0.0000 & 0.0000 & 0.0000 & 0.0000 & 0.0000 & 0.0000 & 0.0000 \\
\hline Nitzschia sp7 & 1.9293 & 0.0000 & 2.2956 & 3.3058 & 0.6645 & 0.6667 & 0.5135 \\
\hline Stephanodiscus sp1 & 0.0000 & 0.0000 & 0.0000 & 0.0000 & 0.1661 & 0.0000 & 1.1553 \\
\hline Brachysira microcephala & 0.0000 & 0.0000 & 0.0000 & 0.0000 & 0.0000 & 0.0000 & 0.2567 \\
\hline Pinnularia sp6 & 0.0000 & 0.0000 & 0.0000 & 0.0000 & 0.0000 & 0.0000 & 0.0000 \\
\hline Cymbella sp1 & 0.0000 & 0.0000 & 0.0000 & 0.0000 & 0.1661 & 0.0000 & 0.0000 \\
\hline Gomphonema sp6 & 0.0000 & 0.0000 & 0.0000 & 0.0000 & 0.0000 & 0.0000 & 0.0000 \\
\hline Navicula chiarae & 0.1608 & 0.0000 & 0.0000 & 0.0000 & 0.0000 & 0.0000 & 0.0000 \\
\hline Denticula sp1 & 1.4469 & 0.0000 & 0.1435 & 0.0000 & 0.1661 & 0.0000 & 0.0000 \\
\hline Gomphonema sp8 & 0.0000 & 0.0000 & 0.0000 & 0.0000 & 0.0000 & 0.0000 & 0.0000 \\
\hline Brachysira sp1 & 0.0000 & 0.0000 & 1.0043 & 0.0000 & 0.1661 & 0.0000 & 0.0000 \\
\hline Navicula sp4 & 0.0000 & 0.0000 & 0.0000 & 0.0000 & 0.0000 & 0.0000 & 0.0000 \\
\hline
\end{tabular}




\begin{tabular}{|c|c|c|c|c|c|c|c|}
\hline & $\pi$ & bund & rea & & & & \\
\hline Taxon & & & & re Depth & & & \\
\hline & $110 \mathrm{~cm}$ & $116 \mathrm{~cm}$ & $123 \mathrm{~cm}$ & $129 \mathrm{~cm}$ & $135 \mathrm{~cm}$ & $141 \mathrm{~cm}$ & $148 \mathrm{~cm}$ \\
\hline Achnanthes minutissimum & 0.8026 & 0.6006 & 3.5370 & 0.7485 & 1.2966 & 0.6431 & 0.1597 \\
\hline Achnanthes petersenii & 0.0000 & 2.3819 & 0.0000 & 0.2994 & 74.9649 & 0.0000 & 2.0283 \\
\hline Aulacoseira ambigua & 0.1605 & 0.0000 & 0.0000 & 0.1497 & 0.3241 & 0.0000 & 0.0000 \\
\hline Encyonema cesatii & 0.1605 & 0.0000 & 0.8039 & 0.0000 & 0.1621 & 0.0000 & 0.0000 \\
\hline Cymbella cistula & 0.0000 & 0.0000 & 0.0000 & 0.0000 & 0.0000 & 0.0000 & 0.0000 \\
\hline Encyonema minuta & 4.3339 & 6.0060 & 4.0193 & 6.8862 & 3.5656 & 4.5016 & 1.5974 \\
\hline Encyonema silesiacum & 0.4815 & 0.6006 & 1.1254 & 0.0000 & 0.6483 & 0.3215 & 0.6390 \\
\hline Cocconeis euglyta & 0.0000 & 0.0000 & 0.0000 & 0.0000 & 0.0000 & 0.0000 & 0.0000 \\
\hline Cyclotella atomus & 0.0000 & 0.0000 & 0.0000 & 0.0000 & 0.0000 & 0.0000 & 0.0000 \\
\hline Cyclotella comensis & 0.0000 & 0.0000 & 0.0000 & 0.0000 & 0.0000 & 0.0000 & 0.0000 \\
\hline C. michiganiana & 0.0000 & 0.0000 & 0.0000 & 0.1497 & 0.0000 & 0.0000 & 0.0000 \\
\hline Cyclotella stelligera & 0.0000 & 0.0000 & 0.0000 & 0.0000 & 0.3241 & 0.0000 & 0.0000 \\
\hline Eunotia flexuosa & 20.0642 & 16.3664 & 14.7910 & 17.8144 & 23.0146 & 19.9357 & 16.2939 \\
\hline E. intermedia & 7.3836 & 3.4535 & 3.8585 & 2.2455 & 2.7553 & 3.5370 & 2.8754 \\
\hline E. praerupta form 1 & 0.4815 & 1.2012 & 0.9646 & 0.4491 & 0.3241 & 0.1608 & 0.3195 \\
\hline Eunotia diadema & 0.0000 & 0.0000 & 0.0000 & 0.0000 & 0.0000 & 0.0000 & 0.0000 \\
\hline Fragilaria brevistriata & 0.0000 & 0.0000 & 0.4823 & 0.2994 & 0.0000 & 0.0000 & 0.0000 \\
\hline Frag. cap. var. cap. & 1.7657 & 0.0000 & 7.5563 & 0.0000 & 5.1864 & 0.1608 & 9.2652 \\
\hline Frag. cap. var. mesolepta & 0.0000 & 0.0000 & 0.0000 & 0.0000 & 0.0000 & 0.0000 & 0.0000 \\
\hline Frag. capucina v. rumpens & 0.0000 & 0.0000 & 0.0000 & 0.2994 & 0.0000 & 0.0000 & 0.0000 \\
\hline Staurosira construens & 0.0000 & 0.0000 & 0.0000 & 0.0000 & 0.0000 & 0.0000 & 0.0000 \\
\hline S. construens $v$. venter & 0.0000 & 0.0000 & 0.0000 & 0.2994 & 0.0000 & 0.0000 & 0.0000 \\
\hline Fragilaria leptostauron & 0.0000 & 0.0000 & 0.0000 & 0.0000 & 0.0000 & 0.0000 & 0.0000 \\
\hline Fragilaria nanana & 9.1493 & 4.6547 & 8.6817 & 1.1976 & 4.3760 & 0.9646 & 0.6390 \\
\hline Fragilaria pinnata & 0.0000 & 0.0000 & 0.0000 & 0.0000 & 0.0000 & 0.0000 & 0.0000 \\
\hline Fragilaria tenera & 25.2006 & 31.2312 & 21.2219 & 37.8743 & 19.7731 & 52.4116 & 38.8179 \\
\hline F. ulna and arcus & 0.0000 & 0.0000 & 0.0000 & 1.1976 & 0.0000 & 0.0000 & 0.0000 \\
\hline Cf. G. acuminatum & 0.0000 & 0.0000 & 0.0000 & 0.5988 & 0.4862 & 0.0000 & 0.0000 \\
\hline Gomphonema micropus & 0.0000 & 0.0000 & 0.0000 & 2.0958 & 0.0000 & 0.0000 & 0.0000 \\
\hline Gomphonema augur & 0.0000 & 0.0000 & 0.0000 & 0.0000 & 0.0000 & 0.0000 & 0.0000 \\
\hline G. angustatumgracileaffine & 0.0000 & 0.0000 & 0.0000 & 8.0838 & 0.0000 & 0.0000 & 0.0000 \\
\hline G. truncatumcapitatum $+\mathrm{sp} 7$ & 0.0000 & 0.0000 & 0.0000 & 0.7485 & 0.0000 & 0.0000 & 0.0000 \\
\hline Nitzschia sp6 & 0.0000 & 0.3003 & 0.0000 & 0.0000 & 0.0000 & 0.0000 & 0.0000 \\
\hline Meridion circulare Fm1 & 0.0000 & 0.0000 & 0.0000 & 0.0000 & 0.0000 & 0.0000 & 0.0000 \\
\hline Navicula sp3 & 0.0000 & 0.0000 & 0.0000 & 0.0000 & 0.3241 & 0.0000 & 0.1597 \\
\hline Naviculacryptocephala & 0.4815 & 0.7508 & 0.9646 & 0.2994 & 4.0519 & 0.3215 & 0.3195 \\
\hline Navicula cryptotonella & 0.4815 & 1.2012 & 0.6431 & 4.3413 & 1.1345 & 1.6077 & 0.9585 \\
\hline Cf. Eolimna minima & 0.0000 & 0.3003 & 0.3215 & 0.4491 & 0.1621 & 0.0000 & 0.0000 \\
\hline Navicula pseudoventralis & 0.0000 & 0.0000 & 0.0000 & 0.0000 & 0.0000 & 0.0000 & 0.0000 \\
\hline Sellaphora pupula & 0.0000 & 6.7568 & 1.9293 & 0.5988 & 0.9724 & 0.0000 & 0.1597 \\
\hline Navicula radiosa & 4.4944 & 6.0060 & 4.3408 & 6.1377 & 6.4830 & 2.0900 & 3.5144 \\
\hline Nitzschia sp4 & 0.0000 & 0.0000 & 1.4469 & 0.0000 & 0.9724 & 0.0000 & 0.0000 \\
\hline Nitzschia gracilis & 2.4077 & 1.3514 & 2.5723 & 0.7485 & 1.7828 & 0.0000 & 0.0000 \\
\hline Pinnularia subanglica & 0.0000 & 0.0000 & 0.0000 & 0.0000 & 0.0000 & 0.0000 & 0.0000 \\
\hline Pinnularia sp4 & 0.0000 & 0.0000 & 0.0000 & 0.0000 & 0.0000 & 0.3215 & 0.0000 \\
\hline Pinnularia viridis & 0.0000 & 0.1502 & 0.0000 & 0.0000 & 0.1621 & 0.0000 & 0.0000 \\
\hline Stauroneis gracilis & 0.0000 & 0.1502 & 0.0000 & 0.0000 & 0.4862 & 0.0000 & 0.4792 \\
\hline Stauroneis sp2 & 0.0000 & 0.0000 & 0.0000 & 0.0000 & 0.0000 & 0.0000 & 0.0000 \\
\hline Stephanodiscus medius & 0.0000 & 0.0000 & 0.0000 & 0.0000 & 0.0000 & 0.0000 & 0.0000 \\
\hline Surirella linearis & 0.0000 & 0.0000 & 0.0000 & 0.0000 & 0.0000 & 0.0000 & 0.0000 \\
\hline T. flocculosa v. 4 & 0.4815 & 0.0000 & 0.3215 & 0.0000 & 0.1621 & 0.0000 & 0.0000 \\
\hline Taballeria fenestrata & 1.4446 & 0.3003 & 0.1608 & 0.0000 & 0.6483 & 0.0000 & 0.0000 \\
\hline Achnanthes $s p$ & 0.0000 & 2.6198 & 0.2751 & 0.1497 & 71.4866 & 0.0000 & 0.2736 \\
\hline A. exigua & 0.0000 & 0.0000 & 0.0000 & 0.0000 & 0.0000 & 0.0000 & 0.0000 \\
\hline A. minut. v. scotica & 0.0000 & 0.0000 & 0.0000 & 0.0000 & 0.0000 & 0.0000 & 0.0000 \\
\hline Aulacoseira islandica & 0.0000 & 0.1502 & 0.0000 & 0.2994 & 0.0000 & 0.0000 & 0.0000 \\
\hline Eunotia sp 1 & 0.0000 & 0.0000 & 0.0000 & 0.0000 & 0.0000 & 0.0000 & 0.0000 \\
\hline Eunotia sp2 & 0.0000 & 0.0000 & 0.0000 & 0.0000 & 0.0000 & 0.0000 & 0.0000 \\
\hline
\end{tabular}




\begin{tabular}{|c|c|c|c|c|c|c|c|}
\hline & tom per & abundar & Teapo & ke, Ont & & & \\
\hline Taxon & & & & e Depth & & & \\
\hline & $110 \mathrm{~cm}$ & $116 \mathrm{~cm}$ & $123 \mathrm{~cm}$ & $129 \mathrm{~cm}$ & $135 \mathrm{~cm}$ & $141 \mathrm{~cm}$ & $148 \mathrm{~cm}$ \\
\hline Eunotia incisa & 3.2103 & 0.4505 & 1.6077 & 0.7485 & 0.6483 & 0.3215 & 0.7987 \\
\hline E. monodon total & 0.0000 & 15.7865 & 0.0000 & 0.4491 & 52.7955 & 0.0000 & 0.7117 \\
\hline E. paludosa & 0.9631 & 2.2523 & 0.4823 & 0.4491 & 0.1621 & 1.9293 & 0.0000 \\
\hline Fragilaria sp1 & 0.0000 & 0.0000 & 0.0000 & 0.0000 & 0.0000 & 0.0000 & 0.0000 \\
\hline Fragilaria sp2 & 0.0000 & 0.0000 & 0.0000 & 0.0000 & 0.0000 & 0.0000 & 0.0000 \\
\hline Fragilaria sp3 & 0.0000 & 0.0000 & 0.0000 & 0.0000 & 0.0000 & 0.0000 & 0.0000 \\
\hline Cf. Frag. neoproducta & 0.0000 & 0.0000 & 0.0000 & 0.1497 & 0.0000 & 0.0000 & 0.3195 \\
\hline Fragilaria senedra & 0.0000 & 0.0000 & 0.0000 & 0.0000 & 0.0000 & 0.0000 & 0.0000 \\
\hline Gomphonema sp2 & 0.1605 & 0.1502 & 0.1608 & 0.0000 & 0.3241 & 0.1608 & 0.3195 \\
\hline Gomphonema sp3 & 0.6421 & 0.6006 & 0.6431 & 0.4491 & 0.4862 & 0.1608 & 0.0000 \\
\hline Gomphonema sp4 & 0.0000 & 0.0000 & 0.1608 & 0.1497 & 0.9724 & 0.0000 & 0.0000 \\
\hline Cf. G. acum. v. Turris & 0.0000 & 0.3003 & 0.0000 & 0.0000 & 0.0000 & 0.0000 & 0.0000 \\
\hline G. cymbelliclinum & 1.1236 & 0.1502 & 0.3215 & 0.4491 & 0.8104 & 0.4823 & 0.1597 \\
\hline Gomphonema gracile & 0.0000 & 0.0000 & 0.0000 & 0.0000 & 0.0000 & 0.0000 & 0.0000 \\
\hline Gparvvparv.f.saprophilum & 0.0000 & 0.0000 & 0.0000 & 0.0000 & 0.0000 & 0.0000 & 0.0000 \\
\hline Neidium sp1 & 0.1605 & 0.0000 & 0.0000 & 0.0000 & 0.0000 & 0.0000 & 0.0000 \\
\hline Neidium sp2 & 0.0000 & 0.0000 & 0.0000 & 0.0000 & 0.0000 & 0.0000 & 0.0000 \\
\hline Neidium affine & 0.0000 & 0.0000 & 0.0000 & 0.0000 & 0.0000 & 0.0000 & 0.0000 \\
\hline Nitzschia sp1 & 0.0000 & 0.0000 & 0.0000 & 0.0000 & 0.0000 & 0.0000 & 0.0000 \\
\hline Nitzschia sp2 & 0.0000 & 0.0000 & 0.0000 & 0.0000 & 0.0000 & 0.0000 & 0.0000 \\
\hline Nitzschia sp3 & 0.0000 & 0.0000 & 0.0000 & 0.0000 & 0.0000 & 0.0000 & 0.0000 \\
\hline Nitzschia perminuta SM & 1.6051 & 0.0000 & 0.9646 & 0.1497 & 0.6483 & 0.0000 & 0.0000 \\
\hline Nitzschia perminuta & 0.6421 & 0.0000 & 0.0000 & 0.0000 & 0.9724 & 0.0000 & 0.3195 \\
\hline Nupela neotropica & 0.0000 & 0.0000 & 0.1608 & 0.0000 & 0.1621 & 0.0000 & 0.1597 \\
\hline Pinnularia macilenta & 0.1605 & 0.3003 & 0.0000 & 0.0000 & 0.3241 & 0.1608 & 0.0000 \\
\hline P. nodosa v. robusta & 0.0000 & 0.0000 & 0.0000 & 0.0000 & 0.0000 & 0.0000 & 0.0000 \\
\hline Stauroneis kriegeri & 0.0000 & 0.0000 & 0.0000 & 0.0000 & 0.1621 & 0.0000 & 0.0000 \\
\hline Stenopterobiaintermedia & 0.3210 & 0.0000 & 0.3215 & 0.5988 & 0.9724 & 0.1608 & 0.3195 \\
\hline Nitzschia agnita & 0.0000 & 0.0000 & 0.3215 & 0.0000 & 1.6207 & 0.0000 & 0.4792 \\
\hline Nitzschia sp5 & 0.0000 & 0.0000 & 0.3215 & 0.0000 & 0.0000 & 0.0000 & 0.0000 \\
\hline Pinnularia sp1 & 0.0000 & 0.0000 & 0.0000 & 0.0000 & 0.0000 & 0.0000 & 0.0000 \\
\hline Achnanthes lanc.lanc. & 0.0000 & 0.0000 & 0.0000 & 0.0000 & 0.0000 & 0.0000 & 0.0000 \\
\hline Meridion sp1 & 0.6421 & 0.0000 & 0.1608 & 0.0000 & 0.3241 & 0.0000 & 0.1597 \\
\hline Gomphonema sp5 & 0.3210 & 0.3003 & 0.3215 & 0.5988 & 0.3241 & 0.0000 & 0.0000 \\
\hline Achnanthes saprophila & 0.0000 & 0.0000 & 0.0000 & 0.0000 & 0.3241 & 0.0000 & 0.0000 \\
\hline Fragilaria sp4 & 0.0000 & 0.0000 & 0.1608 & 0.1497 & 0.0000 & 0.0000 & 0.0000 \\
\hline Pinnularia sp2 & 0.0000 & 0.0000 & 0.8039 & 0.1497 & 0.0000 & 0.0000 & 0.3195 \\
\hline Pinnularia sp3 & 0.0000 & 0.0000 & 0.0000 & 0.0000 & 0.0000 & 0.0000 & 0.0000 \\
\hline Achnanthes holsatica & 0.0000 & 0.0000 & 0.0000 & 0.0000 & 0.0000 & 0.0000 & 0.0000 \\
\hline Pinnularia sp5 & 0.0000 & 0.0000 & 0.0000 & 0.0000 & 0.0000 & 0.0000 & 0.0000 \\
\hline Nitzschia sp7 & 0.6421 & 0.0000 & 1.2862 & 0.0000 & 0.3241 & 0.0000 & 0.0000 \\
\hline Stephanodiscus sp1 & 0.0000 & 0.4505 & 1.2862 & 0.0000 & 0.1621 & 0.0000 & 0.0000 \\
\hline Brachysira microcephala & 0.0000 & 0.1502 & 0.3215 & 0.0000 & 0.0000 & 0.0000 & 0.0000 \\
\hline Pinnularia sp6 & 0.0000 & 0.0000 & 0.0000 & 0.0000 & 0.1621 & 0.3215 & 0.0000 \\
\hline Cymbella sp1 & 0.0000 & 0.4505 & 0.0000 & 0.0000 & 0.1621 & 0.0000 & 0.0000 \\
\hline Gomphonema sp6 & 0.0000 & 0.0000 & 0.0000 & 0.0000 & 0.0000 & 0.0000 & 0.0000 \\
\hline Navicula chiarae & 0.0000 & 0.0000 & 0.0000 & 0.8922 & 0.0000 & 0.0000 & 0.0000 \\
\hline Denticula sp1 & 0.0000 & 1.0511 & 0.0000 & 0.1497 & 0.0000 & 0.4823 & 0.0000 \\
\hline Gomphonema sp8 & 0.0000 & 0.0000 & 0.0000 & 0.0000 & 0.0000 & 0.0000 & 0.0000 \\
\hline Brachysira sp1 & 0.0000 & 0.0000 & 0.0000 & 0.0000 & 0.0000 & 0.0000 & 0.0000 \\
\hline Navicula sp4 & 0.0000 & 0.0000 & 0.0000 & 0.0000 & 0.0000 & 0.0000 & 0.0000 \\
\hline
\end{tabular}




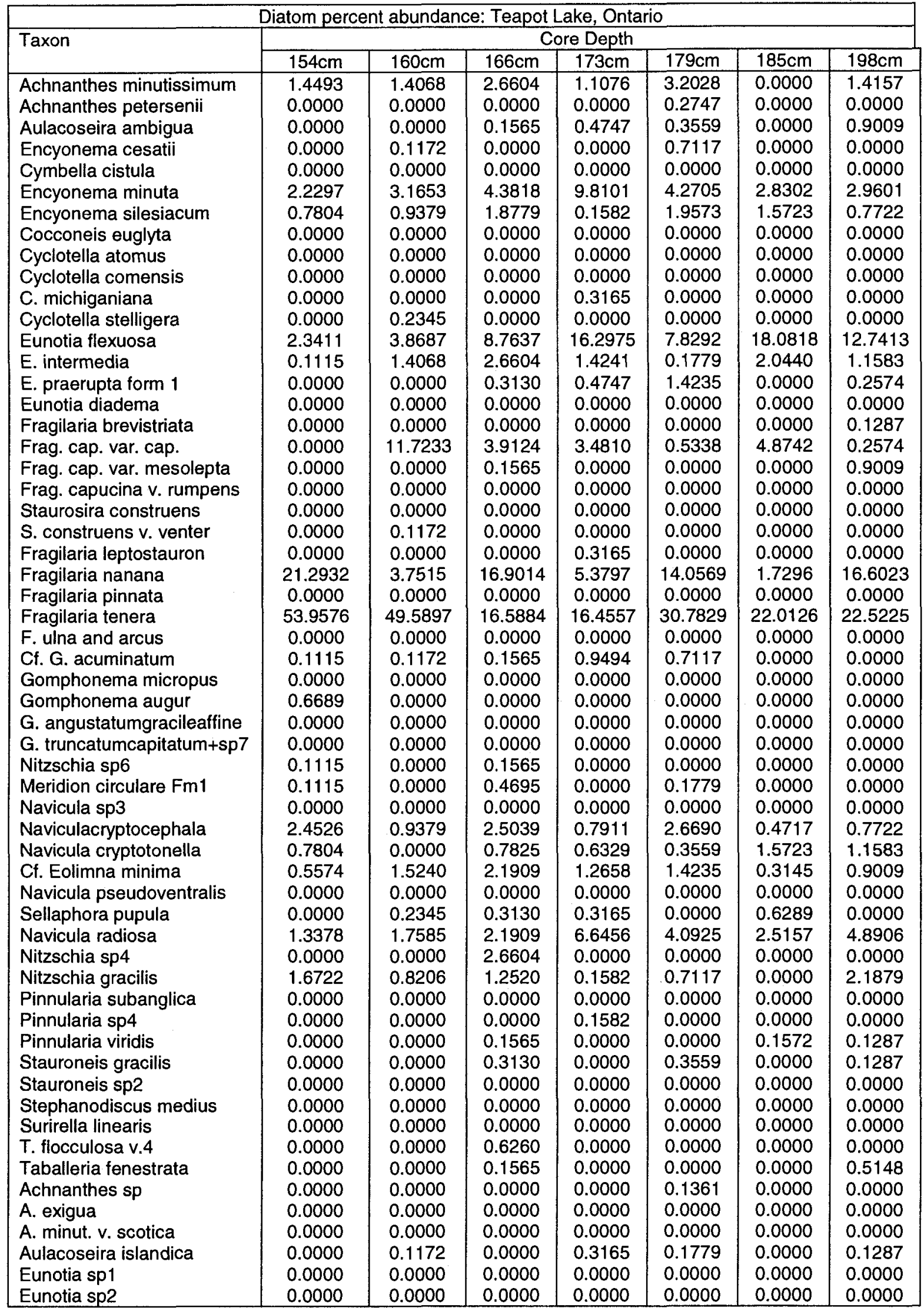




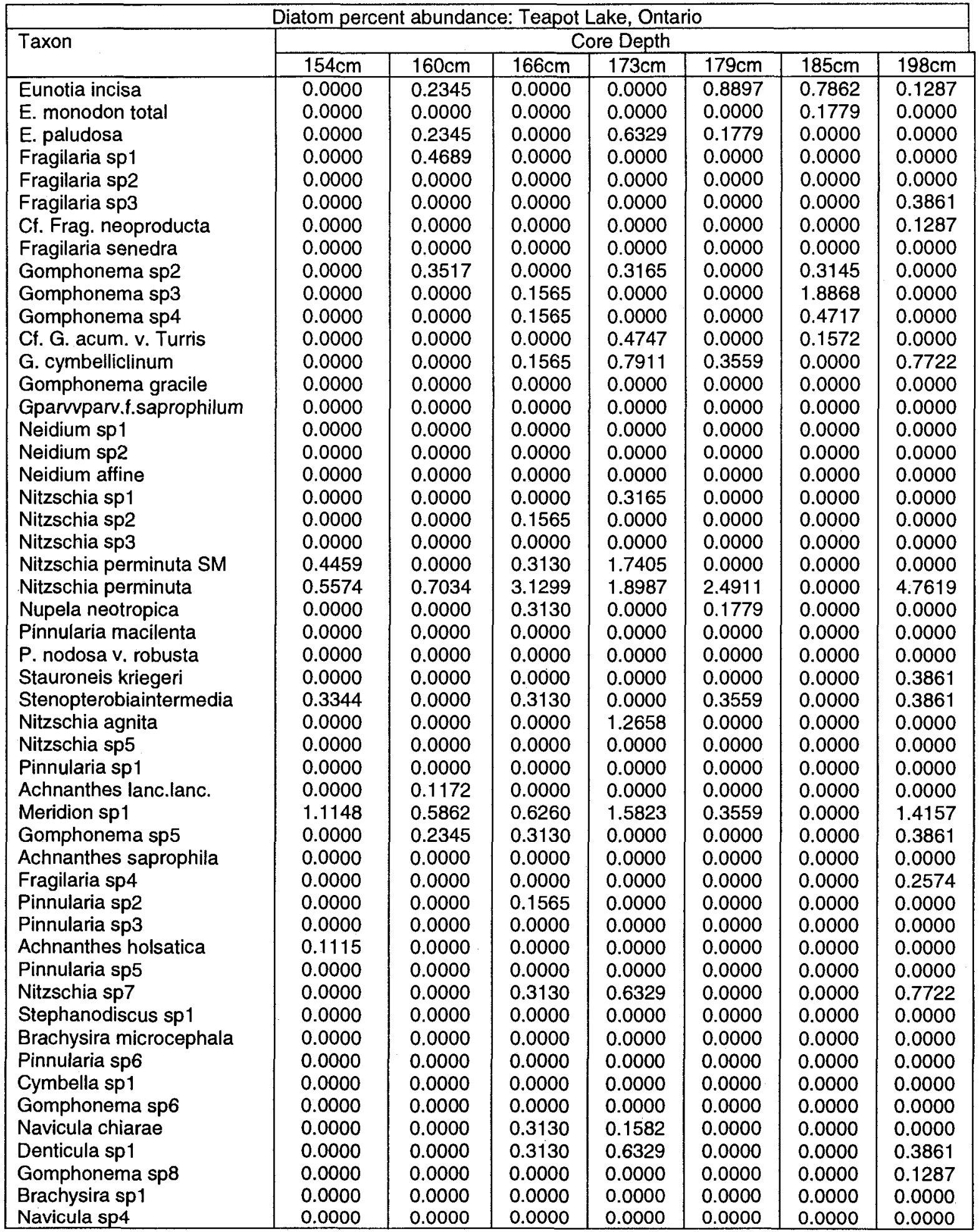




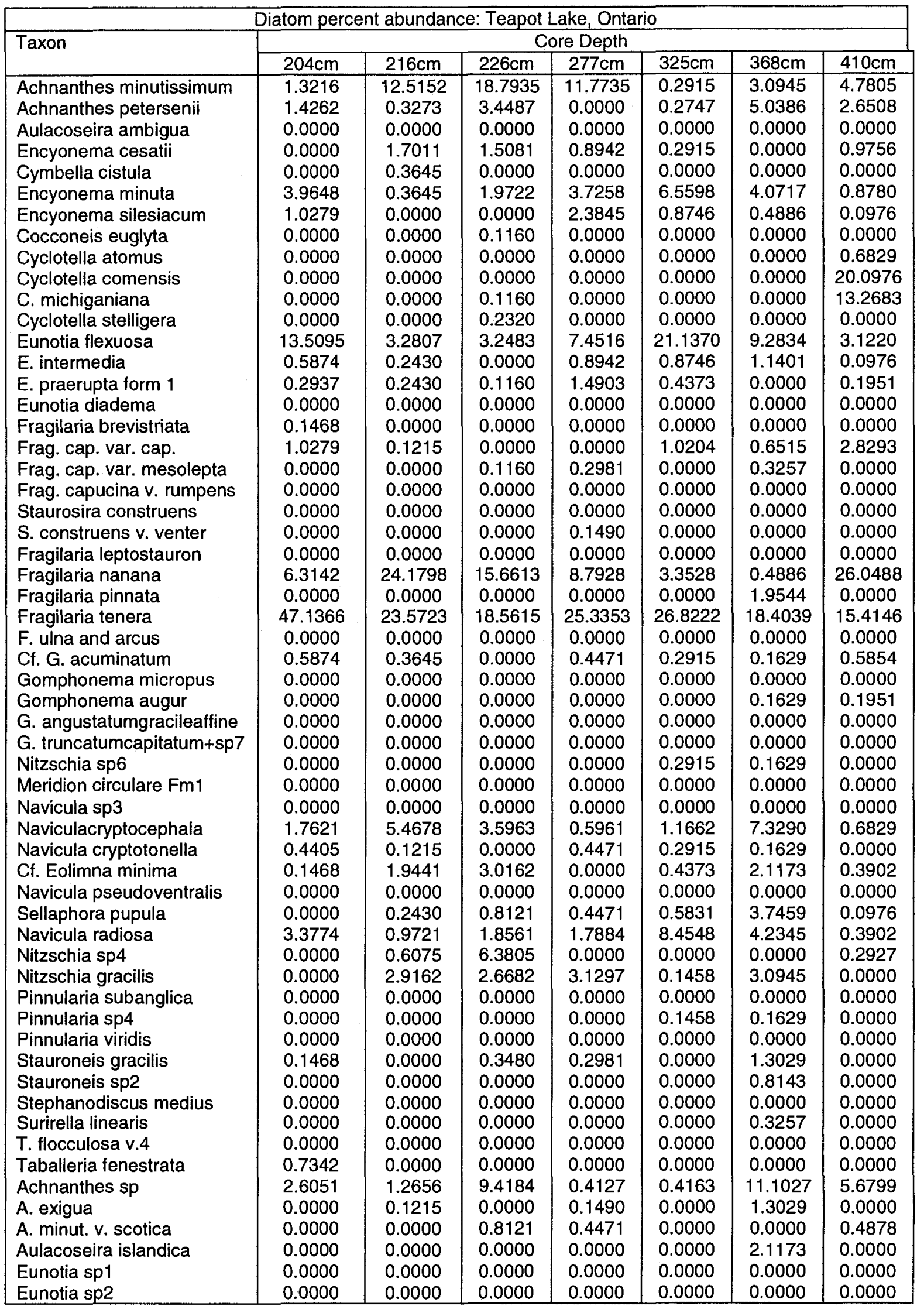




\begin{tabular}{|c|c|c|c|c|c|c|c|}
\hline & atom perc & abunda & Teapo & ke, Ont & & & \\
\hline Taxon & & & & e Depth & & & \\
\hline & $204 \mathrm{~cm}$ & $216 \mathrm{~cm}$ & $226 \mathrm{~cm}$ & $277 \mathrm{~cm}$ & $325 \mathrm{~cm}$ & $368 \mathrm{~cm}$ & $410 \mathrm{~cm}$ \\
\hline Eunotia incisa & 1.4684 & 0.2430 & 0.0000 & 1.4903 & 1.3120 & 1.3029 & 0.0000 \\
\hline E. monodon total & 3.1407 & 1.9282 & 1.7380 & 0.0000 & 0.6289 & 6.6082 & 0.0000 \\
\hline E. paludosa & 0.2937 & 0.0000 & 0.0000 & 0.0000 & 0.1458 & 0.0000 & 0.0000 \\
\hline Fragilaria sp1 & 0.7342 & 0.0000 & 0.0000 & 0.0000 & 0.0000 & 0.0000 & 0.0000 \\
\hline Fragilaria sp2 & 0.0000 & 0.0000 & 0.0000 & 0.0000 & 0.0000 & 0.0000 & 0.0000 \\
\hline Fragilaria sp3 & 0.0000 & 0.0000 & 0.0000 & 0.0000 & 0.0000 & 0.0000 & 0.0000 \\
\hline Cf. Frag. neoproducta & 0.0000 & 0.0000 & 0.0000 & 0.1490 & 0.0000 & 0.4886 & 0.0000 \\
\hline Fragilaria senedra & 0.0000 & 0.0000 & 0.0000 & 0.0000 & 0.0000 & 0.0000 & 0.0000 \\
\hline Gomphonema sp2 & 0.1468 & 0.0000 & 0.1160 & 0.0000 & 0.1458 & 0.0000 & 0.0000 \\
\hline Gomphonema sp3 & 0.2937 & 0.0000 & 0.0000 & 0.0000 & 0.0000 & 0.0000 & 0.0000 \\
\hline Gomphonema sp4 & 0.0000 & 0.0000 & 0.0000 & 0.0000 & 0.1458 & 0.0000 & 0.0000 \\
\hline Cf. G. acum. v. Turris & 0.1468 & 0.2430 & 0.0000 & 0.0000 & 0.0000 & 0.0000 & 0.0000 \\
\hline G. cymbelliclinum & 0.0000 & 0.0000 & 0.0000 & 0.4471 & 0.0000 & 0.9772 & 0.0000 \\
\hline Gomphonema gracile & 0.0000 & 0.0000 & 0.0000 & 0.0000 & 0.0000 & 0.0000 & 0.0000 \\
\hline Gparuparv.t.saprophilum & 0.2937 & 0.2430 & 0.2320 & 0.0000 & 0.0000 & 0.4886 & 0.0000 \\
\hline Neidium sp1 & 0.0000 & 0.0000 & 0.0000 & 0.0000 & 0.0000 & 0.0000 & 0.0000 \\
\hline Neidium sp2 & 0.0000 & 0.0000 & 0.0000 & 0.0000 & 0.0000 & 0.0000 & 0.0000 \\
\hline Neidium affine & 0.0000 & 0.0000 & 0.0000 & 0.0000 & 0.0000 & 1.1401 & 0.0000 \\
\hline Nitzschia sp1 & 0.0000 & 0.0000 & 0.0000 & 0.0000 & 0.0000 & 0.0000 & 0.0000 \\
\hline Nitzschia sp2 & 0.0000 & 0.0000 & 0.0000 & 0.0000 & 0.0000 & 0.0000 & 0.0000 \\
\hline Nitzschia sp3 & 0.0000 & 0.0000 & 0.0000 & 0.0000 & 0.0000 & 0.0000 & 0.0000 \\
\hline Nitzschia perminuta SM & 0.0000 & 0.3645 & 1.2761 & 0.0000 & 0.0000 & 0.0000 & 1.1707 \\
\hline Nitzschia perminuta & 0.4405 & 2.1871 & 2.7842 & 3.2787 & 2.4781 & 0.8143 & 1.3659 \\
\hline Nupela neotropica & 0.0000 & 0.0000 & 0.0000 & 0.0000 & 0.0000 & 0.1629 & 0.0000 \\
\hline Pinnularia macilenta & 0.0000 & 0.0000 & 0.0000 & 0.0000 & 0.0000 & 0.6515 & 0.0000 \\
\hline P. nodosa v. robusta & 0.0000 & 0.0000 & 0.0000 & 0.0000 & 0.0000 & 0.0000 & 0.0000 \\
\hline Stauroneis kriegeri & 0.0000 & 0.2430 & 0.2320 & 0.0000 & 0.0000 & 0.4886 & 0.0000 \\
\hline Stenopterobiaintermedia & 0.0000 & 0.0000 & 0.0000 & 0.1490 & 0.4373 & 0.9772 & 0.0976 \\
\hline Nitzschia agnita & 0.0000 & 0.0000 & 0.0000 & 0.0000 & 0.0000 & 0.0000 & 0.0000 \\
\hline Nitzschia sp5 & 0.0000 & 0.2430 & 2.5522 & 0.0000 & 0.0000 & 0.0000 & 0.0000 \\
\hline Pinnularia sp1 & 0.0000 & 0.2430 & 0.0000 & 0.0000 & 0.0000 & 0.1629 & 0.0000 \\
\hline Achnanthes lanc.lanc. & 0.0000 & 0.0000 & 0.2320 & 0.0000 & 0.0000 & 0.0000 & 0.0000 \\
\hline Meridion sp1 & 0.2937 & 0.0000 & 0.3480 & 0.0000 & 2.6239 & 0.1629 & 0.0000 \\
\hline Gomphonema sp5 & 0.7342 & 0.7290 & 0.4640 & 0.8942 & 1.0204 & 0.0000 & 0.7805 \\
\hline Achnanthes saprophila & 0.0000 & 1.2151 & 0.4640 & 0.1490 & 0.0000 & 0.0000 & 0.3902 \\
\hline Fragilaria sp4 & 0.2937 & 0.0000 & 0.0000 & 0.0000 & 0.2915 & 0.0000 & 0.0000 \\
\hline Pinnularia sp2 & 0.0000 & 0.0000 & 0.0000 & 0.1490 & 0.0000 & 0.0000 & 0.0000 \\
\hline Pinnularia sp3 & 0.0000 & 0.0000 & 0.0000 & 0.0000 & 0.0000 & 0.0000 & 0.0000 \\
\hline Achnanthes holsatica & 0.0000 & 0.0000 & 0.0000 & 0.0000 & 0.0000 & 0.9772 & 0.0000 \\
\hline Pinnularia sp5 & 0.0000 & 0.0000 & 0.0000 & 0.0000 & 0.0000 & 0.0000 & 0.0000 \\
\hline Nitzschia sp7 & 0.0000 & 0.4860 & 0.0000 & 0.5961 & 0.0000 & 0.0000 & 0.1951 \\
\hline Stephanodiscus sp1 & 0.0000 & 0.0000 & 0.0000 & 0.0000 & 0.0000 & 0.0000 & 0.0000 \\
\hline Brachysira microcephala & 0.0000 & 0.0000 & 0.3480 & 4.0238 & 0.0000 & 0.0000 & 0.2927 \\
\hline Pinnularia sp6 & 0.0000 & 0.1215 & 0.0000 & 0.0000 & 0.0000 & 0.0000 & 0.0000 \\
\hline Cymbella sp1 & 0.0000 & 0.0000 & 0.0000 & 0.0000 & 0.0000 & 0.0000 & 0.0000 \\
\hline Gomphonema sp6 & 0.0000 & 0.0000 & 0.0000 & 0.0000 & 0.0000 & 0.1629 & 0.2927 \\
\hline Navicula chiarae & 0.0000 & 0.0000 & 1.8561 & 0.1490 & 0.4373 & 0.1629 & 0.1951 \\
\hline Denticula sp1 & 0.0000 & 0.0000 & 0.4640 & 0.0000 & 0.0000 & 0.0000 & 0.1951 \\
\hline Gomphonema sp8 & 0.0000 & 0.2430 & 0.0000 & 1.0432 & 0.0000 & 0.0000 & 0.0000 \\
\hline Brachysira sp 1 & 0.2937 & 0.1215 & 0.1160 & 0.0000 & 0.0000 & 0.0000 & 0.0000 \\
\hline Navicula sp4 & 0.0000 & 0.0000 & 0.0000 & 0.2981 & 0.0000 & 0.9772 & 0.0000 \\
\hline
\end{tabular}




\section{Appendix 9. Teapot Lake Diatom Subsampling Data}

\begin{tabular}{|c|c|c|c|c|}
\hline $\begin{array}{c}\text { Sample } \\
\text { Depth } \\
\text { (cm) }\end{array}$ & $\begin{array}{c}\text { Total Wet } \\
\text { Weight } \\
\text { (g) }\end{array}$ & $\begin{array}{l}\text { Total Dry } \\
\text { Weight } \\
\text { (g) }\end{array}$ & $\begin{array}{c}\text { Water } \\
\text { Weight } \\
\text { (g) }\end{array}$ & $\begin{array}{c}\text { Subsample } \\
\text { Weight } \\
\text { (g) }\end{array}$ \\
\hline 1.0 & 17.3557 & 16.6667 & 0.6890 & 0.0225 \\
\hline 2.0 & 17.6788 & 16.7408 & 0.9380 & 0.0266 \\
\hline 5.0 & 17.3383 & 16.5396 & 0.7987 & 0.0238 \\
\hline 7.0 & 17.4617 & 16.5787 & 0.8830 & 0.0225 \\
\hline 8.0 & 17.6097 & 16.6936 & 0.9161 & 0.0212 \\
\hline 10.0 & 17.4191 & 16.6732 & 0.7459 & 0.0164 \\
\hline 12.0 & 17.5717 & 16.7628 & 0.8089 & 0.0268 \\
\hline 15.0 & 17.3898 & 16.6090 & 0.7808 & 0.0228 \\
\hline 20.0 & 17.2731 & 16.7179 & 0.5552 & 0.0201 \\
\hline 25.0 & 17.3363 & 16.7588 & 0.5775 & 0.0217 \\
\hline 30.0 & 17.3014 & 16.6355 & 0.6659 & 0.0263 \\
\hline 40.0 & 17.3321 & 16.7578 & 0.5743 & 0.0200 \\
\hline 50.0 & 17.4301 & 16.5135 & 0.9166 & 0.0389 \\
\hline 60.0 & 17.3677 & 16.5822 & 0.7855 & .0200 \\
\hline 70.0 & 18.1764 & 17.2684 & 0.9080 & 0.0265 \\
\hline 75.0 & 17.5852 & 16.8179 & 0.7673 & 0.0255 \\
\hline 85.0 & 17.7960 & 16.7962 & 0.9998 & 0.0239 \\
\hline 90.0 & 17.9518 & 16.6205 & 1.3313 & 0.0200 \\
\hline 95.0 & 17.7402 & 16.7939 & 0.9463 & 0.0332 \\
\hline 100.0 & 17.7240 & 16.6399 & 1.0841 & 0.0200 \\
\hline 105.0 & 17.7276 & 16.7014 & 1.0262 & 0.0200 \\
\hline 110.0 & 17.4091 & 16.5818 & 0.8273 & 0.0200 \\
\hline 116.0 & 17.6424 & 16.7610 & 0.8814 & 0.0307 \\
\hline 123.0 & 17.6953 & 16.9717 & 0.7236 & 0.0400 \\
\hline 129.0 & 17.6902 & 16.7768 & 0.9134 & 0.0303 \\
\hline 135.0 & 17.6033 & 16.7077 & 0.8956 & 0.0300 \\
\hline 141.0 & 17.6843 & 16.7465 & 0.9378 & 0.0308 \\
\hline 148.0 & 17.4416 & 16.5932 & 0.8484 & 0.0363 \\
\hline 154.0 & 17.6882 & 16.7661 & 0.9221 & 0.0309 \\
\hline 160.0 & 17.5672 & 16.6945 & 0.8727 & 0.0516 \\
\hline 166.0 & 17.7512 & 16.8107 & 0.9405 & 0.0351 \\
\hline 173.0 & 17.7545 & 16.8209 & 0.9336 & 0.0410 \\
\hline 179.0 & 17.8211 & 16.9586 & 0.8625 & 0.0335 \\
\hline 185.0 & 17.6271 & 16.6765 & 0.9506 & 0.0505 \\
\hline 198.0 & 17.6598 & 16.566 & 1.0938 & 0.0351 \\
\hline 204.0 & 17.6971 & 16.7699 & 0.9272 & 0.0383 \\
\hline 216.0 & 17.5581 & 16.7733 & 0.7848 & 0.0401 \\
\hline 226.0 & 17.7760 & 16.8767 & 0.8993 & 0.0400 \\
\hline 236.0 & 17.7474 & 16.8877 & 0.8597 & 0.0356 \\
\hline 277.0 & 17.6068 & 16.6990 & 0.9078 & 0.0200 \\
\hline
\end{tabular}




\begin{tabular}{|ccccc|}
\hline $\begin{array}{c}\text { Sample } \\
\text { Depth } \\
(\mathrm{cm})\end{array}$ & $\begin{array}{c}\text { Total Wet } \\
\text { Weight } \\
(\mathrm{g})\end{array}$ & $\begin{array}{c}\text { Total Dry } \\
\text { Weight } \\
(\mathrm{g})\end{array}$ & $\begin{array}{c}\text { Water } \\
\text { Weight } \\
(\mathrm{g})\end{array}$ & $\begin{array}{c}\text { Subsample } \\
\text { Weight } \\
(\mathrm{g})\end{array}$ \\
\hline 325.0 & 17.7131 & 16.8997 & 0.8134 & 0.0200 \\
368.0 & 17.6655 & 16.7468 & 0.9187 & 0.0369 \\
410.0 & 17.5370 & 16.6172 & 0.9198 & 0.0421 \\
\hline
\end{tabular}




\section{Appendix 10. Pollen percent abundance data: Teapot Lake, Ontario}

\begin{tabular}{|c|c|c|c|c|c|c|c|c|}
\hline \multicolumn{9}{|c|}{ Pollen Percent Abundance: Teapot Lake } \\
\hline \multirow{2}{*}{$\begin{array}{l}\text { Core } \\
\text { Depth } \\
\text { (cm) }\end{array}$} & \multicolumn{8}{|c|}{ Taxon } \\
\hline & $\begin{array}{c}\text { Tsuga } \\
\text { canadensis }\end{array}$ & Picea & Abies & $\begin{array}{c}\text { Pinus } \\
\text { haploxylon }\end{array}$ & $\begin{array}{c}\text { Pinus } \\
\text { diploxylon }\end{array}$ & $\begin{array}{c}\text { Undifferentiated } \\
\text { Pinus } \\
\end{array}$ & $\begin{array}{c}\text { Undifferentiated } \\
\text { Pinaceae }\end{array}$ & Cupressaceae \\
\hline 8.00 & 35.53 & 1.54 & 0.88 & 0.00 & 0.66 & 0.66 & 1.32 & 2.19 \\
\hline 22.00 & 27.06 & 0.00 & 0.00 & 0.00 & 2.55 & 0.20 & 1.76 & 2.35 \\
\hline 36.00 & 16.97 & 1.03 & 1.54 & 0.00 & 1.80 & 0.00 & 1.80 & 2.31 \\
\hline 43.00 & 17.65 & 0.00 & 0.71 & 0.00 & 0.71 & 0.47 & 0.71 & 4.94 \\
\hline 50.00 & 24.46 & 0.81 & 0.00 & 0.27 & 0.81 & 0.54 & 1.08 & 1.08 \\
\hline 64.00 & 16.94 & 1.09 & 0.00 & 0.00 & 0.27 & 0.00 & 0.82 & 2.73 \\
\hline 78.00 & 22.25 & 0.26 & 0.26 & 0.00 & 0.52 & 0.00 & 0.79 & 2.09 \\
\hline 92.00 & 15.96 & 0.22 & 1.33 & 0.44 & 0.89 & 0.22 & 0.44 & 1.55 \\
\hline 99.00 & 17.27 & 1.81 & 0.00 & 0.00 & 0.40 & 0.60 & 0.40 & 2.21 \\
\hline 107.00 & 15.29 & 1.94 & 0.49 & 0.00 & 0.24 & 0.00 & 1.46 & 1.70 \\
\hline 110.00 & 18.72 & 0.80 & 0.53 & 0.27 & 0.80 & 0.27 & 0.80 & 0.80 \\
\hline 117.00 & 14.35 & 0.71 & 1.18 & 0.71 & 0.24 & 0.00 & 0.94 & 12.00 \\
\hline 131.00 & 15.18 & 0.39 & 0.39 & 0.78 & 1.56 & 1.56 & 0.39 & 0.78 \\
\hline 138.00 & 21.54 & 0.19 & 0.96 & 0.00 & 0.00 & 0.00 & 2.12 & 2.12 \\
\hline 152.00 & 10.48 & 1.21 & 1.41 & 0.81 & 1.01 & 0.00 & 0.81 & 2.42 \\
\hline 166.00 & 14.17 & 0.81 & 0.00 & 0.40 & 0.81 & 0.40 & 1.42 & 1.01 \\
\hline 180.00 & 5.87 & 1.17 & 0.78 & 0.98 & 0.20 & 0.20 & 0.59 & 5.48 \\
\hline 187.00 & 38.61 & 1.04 & 0.58 & 0.23 & 1.39 & 0.00 & 0.69 & 1.39 \\
\hline 194.00 & 4.02 & 0.57 & 0.00 & 0.29 & 0.00 & 0.00 & 1.44 & 0.57 \\
\hline 201.00 & 4.33 & 2.64 & 2.26 & 0.94 & 3.39 & 0.00 & 2.45 & 1.51 \\
\hline 214.00 & 7.84 & 6.67 & 2.61 & 0.78 & 6.54 & 0.39 & 1.05 & 0.78 \\
\hline 228.00 & 2.43 & 1.46 & 0.16 & 0.00 & 2.11 & 0.00 & 0.81 & 4.05 \\
\hline 242.00 & 7.02 & 0.78 & 0.16 & 0.62 & 1.25 & 0.00 & 0.78 & 3.59 \\
\hline 249.00 & 6.49 & 2.16 & 0.36 & 0.00 & 0.36 & 0.00 & 1.62 & 2.34 \\
\hline 262.00 & 10.10 & 2.56 & 0.64 & 0.64 & 0.96 & 0.00 & 2.56 & 1.28 \\
\hline 277.00 & 27.72 & 0.41 & 0.27 & 0.00 & 0.41 & 0.00 & 0.41 & 1.22 \\
\hline 291.00 & 23.15 & 0.62 & 0.15 & 0.15 & 0.62 & 0.00 & 0.00 & 1.54 \\
\hline 305.00 & 15.95 & 0.00 & 0.00 & 0.00 & 0.33 & 0.00 & 0.33 & 0.82 \\
\hline 322.00 & 1.41 & 0.31 & 0.00 & 0.00 & 0.94 & 0.00 & 0.47 & 1.88 \\
\hline 336.00 & 3.03 & 2.42 & 1.06 & 0.30 & 1.06 & 0.00 & 0.76 & 0.61 \\
\hline 350.00 & 1.83 & 4.73 & 0.46 & 0.00 & 1.22 & 0.00 & 0.30 & 0.46 \\
\hline 356.00 & 4.68 & 2.42 & 0.30 & 0.76 & 2.57 & 0.00 & 1.81 & 1.36 \\
\hline 371.00 & 2.79 & 2.65 & 0.56 & 0.28 & 0.42 & 0.00 & 0.56 & 1.54 \\
\hline 385.00 & 4.64 & 1.77 & 0.55 & 0.00 & 0.14 & 0.00 & 0.41 & 0.55 \\
\hline 399.00 & 2.98 & 1.70 & 0.14 & 0.00 & 0.14 & 0.00 & 0.28 & 1.42 \\
\hline 413.00 & 27.83 & 0.46 & 0.00 & 0.00 & 0.69 & 0.00 & 0.00 & 0.12 \\
\hline 429.50 & 12.48 & 9.19 & 0.13 & 0.26 & 1.44 & 0.00 & 0.26 & 0.26 \\
\hline 443.50 & 10.16 & 5.46 & 0.38 & 0.13 & 0.76 & 0.00 & 2.41 & 0.25 \\
\hline 457.50 & 3.14 & 22.92 & 1.05 & 0.12 & 1.63 & 0.00 & 1.75 & 0.35 \\
\hline 471.50 & 1.42 & 30.10 & 0.88 & 0.11 & 1.20 & 0.33 & 0.00 & 0.11 \\
\hline 478.50 & 1.37 & 24.03 & 0.91 & 0.18 & 1.37 & 0.00 & 0.09 & 0.37 \\
\hline 497.50 & 7.88 & 8.61 & 0.36 & 0.00 & 1.58 & 0.00 & 0.12 & 0.36 \\
\hline
\end{tabular}




\begin{tabular}{|c|c|c|c|c|c|c|c|c|}
\hline \multicolumn{9}{|c|}{ Pollen Percent Abundance: Teapot Lake } \\
\hline \multirow{2}{*}{$\begin{array}{l}\text { Core } \\
\text { Depth } \\
\text { (cm) }\end{array}$} & \multicolumn{8}{|c|}{ Taxon } \\
\hline & Larix & Salix & $\begin{array}{l}\text { Acer } \\
\text { rubrum }\end{array}$ & $\begin{array}{c}\text { Acer } \\
\text { negundo }\end{array}$ & $\begin{array}{c}\text { Acer } \\
\text { saccharinum }\end{array}$ & $\begin{array}{c}\text { Undifferentiated } \\
\text { Acer }\end{array}$ & Quercus & Fraxinus \\
\hline 8.00 & 1.10 & 1.97 & 0.00 & 0.00 & 0.00 & 1.97 & 1.32 & 1.10 \\
\hline 22.00 & 1.37 & 0.98 & 0.00 & 0.00 & 0.00 & 0.20 & 3.14 & 1.37 \\
\hline 36.00 & 4.37 & 0.26 & 0.00 & 0.00 & 0.00 & 0.26 & 3.08 & 1.29 \\
\hline 43.00 & 3.06 & 0.24 & 0.00 & 0.00 & 0.00 & 0.00 & 4.00 & 0.94 \\
\hline 50.00 & 1.61 & 1.08 & 0.00 & 0.00 & 0.00 & 0.00 & 4.03 & 0.00 \\
\hline 64.00 & 2.19 & 0.55 & 0.00 & 0.00 & 0.00 & 0.00 & 3.01 & 0.82 \\
\hline 78.00 & 1.57 & 1.05 & 0.00 & 0.00 & 0.00 & 0.00 & 1.57 & 0.79 \\
\hline 92.00 & 1.55 & 0.67 & 0.00 & 0.00 & 0.00 & 0.44 & 3.77 & 0.44 \\
\hline 99.00 & 1.61 & 0.60 & 0.00 & 0.00 & 0.00 & 0.20 & 4.02 & 1.00 \\
\hline 107.00 & 2.67 & 2.43 & 0.00 & 0.00 & 0.00 & 0.49 & 5.58 & 1.21 \\
\hline 110.00 & 1.60 & 0.27 & 0.00 & 0.00 & 0.00 & 0.27 & 2.67 & 0.53 \\
\hline 117.00 & 0.94 & 0.00 & 0.00 & 0.00 & 0.00 & 0.24 & 1.88 & 0.94 \\
\hline 131.00 & 0.39 & 0.00 & 0.00 & 0.00 & 0.00 & 0.00 & 0.78 & 0.00 \\
\hline 138.00 & 0.77 & 0.77 & 0.00 & 0.00 & 0.00 & 0.19 & 0.96 & 0.00 \\
\hline 152.00 & 2.02 & 0.60 & 0.00 & 0.00 & 0.00 & 0.40 & 2.22 & 0.00 \\
\hline 166.00 & 0.61 & 0.20 & 0.00 & 0.00 & 0.00 & 0.20 & 1.21 & 0.00 \\
\hline 180.00 & 0.59 & 0.78 & 0.00 & 0.00 & 0.00 & 0.20 & 1.57 & 0.00 \\
\hline 187.00 & 0.12 & 0.23 & 0.00 & 0.00 & 0.00 & 0.81 & 5.43 & 0.12 \\
\hline 194.00 & 0.00 & 0.00 & 0.00 & 0.00 & 0.00 & 0.00 & 3.45 & 0.00 \\
\hline 201.00 & 0.00 & 0.38 & 0.00 & 0.00 & 0.00 & 0.56 & 5.27 & 0.19 \\
\hline 214.00 & 0.39 & 1.44 & 0.00 & 0.00 & 0.00 & 1.05 & 4.58 & 1.05 \\
\hline 228.00 & 0.49 & 0.97 & 0.00 & 0.00 & 3.73 & 0.00 & 7.94 & 0.97 \\
\hline 242.00 & 0.31 & 0.94 & 0.00 & 0.00 & 1.40 & 0.00 & 6.40 & 1.72 \\
\hline 249.00 & 0.72 & 0.00 & 0.18 & 0.00 & 0.18 & 0.00 & 0.72 & 0.54 \\
\hline 262.00 & 0.48 & 0.00 & 0.48 & 0.00 & 0.00 & 0.00 & 2.72 & 0.64 \\
\hline 277.00 & 1.49 & 0.14 & 0.00 & 0.00 & 0.00 & 0.41 & 3.13 & 1.09 \\
\hline 291.00 & 1.39 & 0.00 & 0.31 & 0.00 & 0.00 & 0.00 & 8.18 & 0.93 \\
\hline 305.00 & 0.00 & 0.00 & 0.00 & 0.00 & 0.00 & 0.00 & 1.81 & 0.16 \\
\hline 322.00 & 0.31 & 0.16 & 0.00 & 0.00 & 1.72 & 0.00 & 5.63 & 2.19 \\
\hline 336.00 & 0.00 & 0.15 & 0.76 & 0.00 & 0.45 & 0.00 & 1.06 & 1.52 \\
\hline 350.00 & 3.81 & 0.00 & 0.00 & 0.00 & 0.30 & 0.00 & 4.12 & 1.83 \\
\hline 356.00 & 0.15 & 0.00 & 0.30 & 0.00 & 0.00 & 0.00 & 3.93 & 1.51 \\
\hline 371.00 & 0.70 & 0.00 & 0.84 & 0.00 & 0.84 & 0.00 & 6.56 & 1.82 \\
\hline 385.00 & 0.41 & 0.27 & 0.14 & 0.00 & 2.86 & 0.00 & 1.91 & 0.95 \\
\hline 399.00 & 0.28 & 0.00 & 0.14 & 0.00 & 0.85 & 0.00 & 2.98 & 2.56 \\
\hline 413.00 & 0.46 & 0.00 & 0.35 & 0.00 & 0.46 & 0.00 & 2.42 & 0.92 \\
\hline 429.50 & 0.53 & 0.00 & 0.00 & 0.00 & 0.00 & 0.00 & 7.62 & 1.31 \\
\hline 443.50 & 0.38 & 0.00 & 0.38 & 0.00 & 1.02 & 0.00 & 10.16 & 0.51 \\
\hline 457.50 & 0.93 & 0.23 & 0.12 & 0.00 & 0.58 & 0.00 & 5.82 & 0.35 \\
\hline 471.50 & 2.08 & 0.00 & 0.22 & 0.00 & 0.22 & 0.00 & 3.83 & 0.11 \\
\hline 478.50 & 3.75 & 0.00 & 0.09 & 0.00 & 1.19 & 0.00 & 8.31 & 0.46 \\
\hline 497.50 & 2.55 & 0.00 & 0.24 & 0.00 & 0.85 & 0.00 & 6.19 & 0.97 \\
\hline
\end{tabular}




\begin{tabular}{|c|c|c|c|c|c|c|c|c|}
\hline \multicolumn{9}{|c|}{ Pollen Percent Abundance: Teapot Lake } \\
\hline \multirow{2}{*}{$\begin{array}{l}\text { Core } \\
\text { Depth } \\
\text { (cm) }\end{array}$} & \multicolumn{8}{|c|}{ Taxon } \\
\hline & Ulmus & Celtis & Fagus & $\begin{array}{c}\text { Ostrya/ } \\
\text { Carpinus }\end{array}$ & Tilia & Juglans & Carya & Populus \\
\hline 8.00 & 2.63 & 0.00 & 20.83 & 2.41 & 0.00 & 0.88 & 0.00 & 0.00 \\
\hline 22.00 & 4.51 & 0.00 & 28.43 & 0.20 & 1.57 & 0.00 & 0.00 & 0.00 \\
\hline 36.00 & 3.08 & 0.00 & 30.59 & 0.77 & 1.03 & 0.00 & 0.00 & 0.00 \\
\hline 43.00 & 5.65 & 0.00 & 33.41 & 1.65 & 0.94 & 0.00 & 0.24 & 0.47 \\
\hline 50.00 & 2.96 & 0.00 & 33.33 & 1.34 & 0.27 & 0.00 & 0.00 & 0.00 \\
\hline 64.00 & 3.01 & 0.00 & 33.61 & 0.82 & 0.27 & 0.55 & 0.00 & 0.00 \\
\hline 78.00 & 4.45 & 0.00 & 26.70 & 0.52 & 0.26 & 0.52 & 0.26 & 0.26 \\
\hline 92.00 & 6.87 & 0.00 & 29.05 & 0.00 & 0.22 & 0.22 & 0.00 & 0.44 \\
\hline 99.00 & 8.03 & 0.00 & 21.89 & 0.40 & 0.60 & 0.80 & 2.21 & 0.20 \\
\hline 107.00 & 3.88 & 0.00 & 21.12 & 1.21 & 1.70 & 0.24 & 0.49 & 0.24 \\
\hline 110.00 & 4.55 & 0.00 & 22.46 & 1.07 & 0.53 & 0.27 & 0.80 & 0.27 \\
\hline 117.00 & 5.65 & 0.00 & 22.12 & 0.24 & 0.00 & 0.00 & 0.71 & 0.00 \\
\hline 131.00 & 1.17 & 0.00 & 13.23 & 0.00 & 0.00 & 0.00 & 0.00 & 0.00 \\
\hline 138.00 & 5.77 & 0.00 & 22.31 & 0.00 & 0.00 & 0.00 & 0.38 & 0.00 \\
\hline 152.00 & 4.44 & 0.00 & 24.40 & 0.00 & 0.00 & 0.00 & 0.81 & 0.00 \\
\hline 166.00 & 4.05 & 0.00 & 25.30 & 0.00 & 0.00 & 0.00 & 1.82 & 0.20 \\
\hline 180.00 & 3.91 & 0.39 & 22.11 & 0.20 & 0.39 & 0.00 & 0.98 & 0.00 \\
\hline 187.00 & 4.16 & 0.00 & 11.91 & 0.81 & 0.92 & 0.12 & 0.12 & 0.46 \\
\hline 194.00 & 2.01 & 0.00 & 18.39 & 0.00 & 0.00 & 0.29 & 0.57 & 0.00 \\
\hline 201.00 & 5.65 & 0.00 & 17.51 & 0.19 & 1.51 & 0.38 & 0.56 & 0.38 \\
\hline 214.00 & 6.80 & 0.00 & 11.50 & 0.39 & 0.39 & 0.92 & 1.31 & 0.00 \\
\hline 228.00 & 5.19 & 0.00 & 16.21 & 1.13 & 0.97 & 0.65 & 0.97 & 0.00 \\
\hline 242.00 & 6.24 & 0.00 & 15.29 & 0.31 & 0.31 & 0.78 & 1.25 & 0.16 \\
\hline 249.00 & 2.70 & 0.36 & 15.32 & 0.36 & 0.72 & 0.00 & 0.36 & 0.54 \\
\hline 262.00 & 2.40 & 0.00 & 22.28 & 0.48 & 0.32 & 0.00 & 1.28 & 0.00 \\
\hline 277.00 & 5.16 & 0.00 & 12.91 & 0.54 & 0.00 & 0.14 & 0.41 & 0.14 \\
\hline 291.00 & 3.55 & 0.00 & 9.10 & 0.15 & 0.62 & 0.15 & 0.31 & 0.15 \\
\hline 305.00 & 2.96 & 0.00 & 12.17 & 0.16 & 0.49 & 0.00 & 0.99 & 0.33 \\
\hline 322.00 & 3.29 & 0.00 & 14.55 & 1.41 & 1.10 & 0.16 & 0.94 & 0.00 \\
\hline 336.00 & 6.06 & 0.00 & 13.18 & 1.67 & 0.15 & 0.30 & 1.21 & 0.00 \\
\hline 350.00 & 3.66 & 0.00 & 11.13 & 0.30 & 0.91 & 0.15 & 2.59 & 0.00 \\
\hline 356.00 & 3.02 & 0.00 & 10.57 & 0.45 & 0.15 & 0.00 & 1.36 & 0.15 \\
\hline 371.00 & 4.75 & 0.00 & 10.20 & 1.68 & 0.70 & 0.84 & 1.96 & 0.28 \\
\hline 385.00 & 3.68 & 0.00 & 14.32 & 0.68 & 0.68 & 1.09 & 1.64 & 0.27 \\
\hline 399.00 & 3.13 & 0.00 & 15.63 & 0.00 & 0.43 & 0.71 & 2.70 & 0.00 \\
\hline 413.00 & 2.08 & 0.00 & 10.74 & 0.23 & 0.46 & 0.81 & 0.46 & 0.12 \\
\hline 429.50 & 1.97 & 0.00 & 1.18 & 0.92 & 0.39 & 0.00 & 0.00 & 0.00 \\
\hline 443.50 & 1.65 & 0.00 & 1.90 & 1.40 & 0.89 & 0.25 & 0.25 & 0.00 \\
\hline 457.50 & 1.75 & 0.00 & 0.70 & 0.81 & 0.12 & 0.12 & 0.00 & 0.00 \\
\hline 471.50 & 1.86 & 0.00 & 0.22 & 2.08 & 0.33 & 0.11 & 0.00 & 0.00 \\
\hline 478.50 & 1.64 & 0.55 & 0.46 & 1.55 & 0.27 & 0.09 & 0.82 & 0.09 \\
\hline 497.50 & 1.82 & 0.00 & 3.03 & 1.09 & 0.24 & 0.12 & 0.36 & 0.00 \\
\hline
\end{tabular}




\begin{tabular}{|c|c|c|c|c|c|c|c|c|}
\hline \multicolumn{9}{|c|}{ Pollen Percent Abundance: Teapot Lake } \\
\hline \multirow{2}{*}{$\begin{array}{l}\text { Core } \\
\text { Depth } \\
\text { (cm) }\end{array}$} & \multicolumn{8}{|c|}{ Taxon } \\
\hline & Morus & Cornus & Betula & Alnus & $\begin{array}{l}\text { Polygonom } \\
\text { amphibian }\end{array}$ & Petalostemum & Rubus & Rumex \\
\hline 8.00 & 0.00 & 0.00 & 8.11 & 0.66 & 0.00 & 0.00 & 0.00 & 0.00 \\
\hline 22.00 & 0.00 & 0.00 & 5.49 & 1.18 & 0.00 & 0.00 & 0.00 & 0.00 \\
\hline 36.00 & 0.00 & 0.00 & 2.83 & 1.80 & 0.00 & 0.00 & 0.00 & 0.00 \\
\hline 43.00 & 0.00 & 0.00 & 4.47 & 1.18 & 0.00 & 0.00 & 0.00 & 0.00 \\
\hline 50.00 & 0.00 & 0.00 & 2.42 & 1.61 & 0.00 & 0.00 & 0.00 & 0.00 \\
\hline 64.00 & 0.00 & 0.00 & 3.83 & 0.82 & 0.00 & 0.00 & 0.00 & 0.00 \\
\hline 78.00 & 0.00 & 0.00 & 4.71 & 0.26 & 0.00 & 0.00 & 0.00 & 0.00 \\
\hline 92.00 & 0.00 & 0.00 & 2.44 & 0.67 & 0.00 & 0.00 & 0.00 & 0.00 \\
\hline 99.00 & 0.00 & 0.00 & 3.82 & 0.60 & 0.00 & 0.40 & 0.00 & 0.00 \\
\hline 107.00 & 0.00 & 0.00 & 2.91 & 1.70 & 0.00 & 1.70 & 0.00 & 0.00 \\
\hline 110.00 & 0.00 & 0.00 & 2.41 & 1.34 & 0.00 & 0.53 & 0.00 & 0.00 \\
\hline 117.00 & 1.65 & 0.00 & 3.29 & 0.71 & 0.00 & 0.00 & 0.00 & 0.00 \\
\hline 131.00 & 0.00 & 0.00 & 1.95 & 0.00 & 0.00 & 0.00 & 0.00 & 0.00 \\
\hline 138.00 & 0.00 & 0.00 & 7.50 & 0.00 & 0.00 & 0.00 & 0.00 & 0.00 \\
\hline 152.00 & 0.00 & 0.00 & 6.45 & 3.83 & 0.00 & 0.00 & 0.00 & 0.00 \\
\hline 166.00 & 0.00 & 0.20 & 0.61 & 1.21 & 0.00 & 0.00 & 0.00 & 0.00 \\
\hline 180.00 & 0.00 & 0.00 & 6.85 & 0.78 & 0.00 & 0.00 & 0.00 & 0.00 \\
\hline 187.00 & 0.00 & 0.00 & 3.70 & 0.81 & 0.00 & 0.00 & 0.00 & 0.23 \\
\hline 194.00 & 0.00 & 0.00 & 1.72 & 1.15 & 0.00 & 0.00 & 0.00 & 0.00 \\
\hline 201.00 & 0.00 & 0.00 & 3.95 & 0.56 & 0.00 & 0.00 & 0.00 & 0.00 \\
\hline 214.00 & 0.00 & 0.00 & 4.31 & 1.31 & 0.00 & 0.00 & 0.00 & 1.05 \\
\hline 228.00 & 0.00 & 0.00 & 6.48 & 0.00 & 0.00 & 0.00 & 0.00 & 0.00 \\
\hline 242.00 & 0.00 & 0.00 & 3.90 & 0.31 & 0.00 & 0.00 & 0.00 & 0.00 \\
\hline 249.00 & 0.00 & 0.00 & 1.08 & 0.36 & 0.00 & 0.18 & 0.00 & 0.00 \\
\hline 262.00 & 0.00 & 0.00 & 1.12 & 0.00 & 0.00 & 0.00 & 0.16 & 0.00 \\
\hline 277.00 & 0.00 & 0.00 & 0.14 & 0.00 & 0.41 & 0.00 & 0.41 & 0.00 \\
\hline 291.00 & 0.00 & 0.00 & 0.93 & 0.00 & 0.31 & 0.00 & 0.46 & 0.00 \\
\hline 305.00 & 0.00 & 0.00 & 0.16 & 0.66 & 0.00 & 0.00 & 0.00 & 0.00 \\
\hline 322.00 & 0.00 & 0.00 & 4.07 & 2.82 & 0.00 & 0.00 & 0.00 & 0.00 \\
\hline 336.00 & 0.00 & 0.00 & 3.18 & 0.61 & 0.00 & 0.00 & 0.00 & 0.76 \\
\hline 350.00 & 0.00 & 0.00 & 2.74 & 0.00 & 0.00 & 0.00 & 0.00 & 0.00 \\
\hline 356.00 & 0.00 & 0.00 & 1.66 & 0.45 & 0.15 & 0.00 & 0.00 & 0.45 \\
\hline 371.00 & 0.00 & 0.00 & 3.21 & 0.28 & 0.28 & 0.14 & 0.00 & 0.28 \\
\hline 385.00 & 0.00 & 0.00 & 4.23 & 0.14 & 0.00 & 0.41 & 0.00 & 0.00 \\
\hline 399.00 & 0.00 & 0.00 & 2.70 & 0.14 & 0.00 & 0.28 & 0.00 & 0.00 \\
\hline 413.00 & 0.00 & 0.00 & 1.62 & 0.23 & 0.00 & 0.00 & 0.00 & 0.00 \\
\hline 429.50 & 0.00 & 0.13 & 2.10 & 0.00 & 0.00 & 0.13 & 0.00 & 0.00 \\
\hline 443.50 & 0.00 & 0.00 & 2.29 & 0.25 & 0.00 & 0.00 & 0.00 & 0.00 \\
\hline 457.50 & 0.00 & 0.00 & 2.33 & 0.00 & 0.23 & 0.00 & 0.00 & 0.00 \\
\hline 471.50 & 0.00 & 0.00 & 0.33 & 0.33 & 0.00 & 0.00 & 0.00 & 0.00 \\
\hline 478.50 & 0.00 & 0.00 & 4.29 & 0.00 & 0.00 & 0.00 & 0.00 & 0.82 \\
\hline 497.50 & 0.00 & 0.00 & 1.21 & 0.12 & 0.00 & 0.00 & 0.00 & 0.00 \\
\hline
\end{tabular}




\begin{tabular}{|c|c|c|c|c|c|c|c|c|}
\hline \multicolumn{9}{|c|}{ Pollen Percent Abundance: Teapot Lake } \\
\hline \multirow{2}{*}{$\begin{array}{l}\text { Core } \\
\text { Depth } \\
(\mathrm{cm})\end{array}$} & \multicolumn{8}{|c|}{ Taxon } \\
\hline & Chenopodiaceae & Plantago & Helianthus & Ambrosia & Artemisia & Portulaca & Andropogon & Zea \\
\hline 8.00 & 0.00 & 0.00 & 0.00 & 0.22 & 0.00 & 0.44 & 0.00 & 0.44 \\
\hline 22.00 & 0.00 & 0.20 & 0.20 & 0.00 & 0.00 & 0.00 & 0.00 & 0.00 \\
\hline 36.00 & 0.00 & 0.00 & 0.00 & 0.00 & 0.00 & 0.00 & 0.00 & 0.00 \\
\hline 43.00 & 0.00 & 0.00 & 0.00 & 0.24 & 0.00 & 0.00 & 0.00 & 0.00 \\
\hline 50.00 & 0.00 & 0.00 & 0.00 & 0.27 & 0.27 & 0.00 & 0.00 & 0.00 \\
\hline 64.00 & 0.00 & 0.00 & 0.00 & 0.27 & 0.00 & 0.00 & 0.00 & 0.00 \\
\hline 78.00 & 0.00 & 0.00 & 0.52 & 0.00 & 0.00 & 0.00 & 0.00 & 0.00 \\
\hline 92.00 & 0.44 & 0.00 & 0.00 & 1.11 & 0.00 & 0.00 & 0.00 & 0.00 \\
\hline 99.00 & 0.00 & 0.00 & 0.00 & 0.20 & 0.20 & 0.00 & 0.00 & 0.00 \\
\hline 107.00 & 0.49 & 0.00 & 0.00 & 0.24 & 0.00 & 0.00 & 0.00 & 0.00 \\
\hline 110.00 & 0.00 & 0.00 & 0.00 & 0.00 & 0.00 & 0.00 & 0.00 & 0.00 \\
\hline 117.00 & 0.00 & 0.00 & 0.00 & 0.00 & 0.00 & 0.00 & 0.00 & 0.00 \\
\hline 131.00 & 0.00 & 0.00 & 0.00 & 0.00 & 0.00 & 0.00 & 0.39 & 0.00 \\
\hline 138.00 & 0.00 & 0.00 & 0.00 & 0.00 & 0.00 & 0.00 & 0.00 & 0.00 \\
\hline 152.00 & 0.00 & 0.00 & 0.00 & 0.00 & 0.00 & 0.00 & 0.00 & 0.00 \\
\hline 166.00 & 0.00 & 0.00 & 0.00 & 0.20 & 0.00 & 0.00 & 0.00 & 0.00 \\
\hline 180.00 & 0.00 & 0.00 & 0.00 & 0.00 & 0.00 & 0.00 & 0.20 & 0.00 \\
\hline 187.00 & 0.00 & 0.00 & 0.00 & 0.00 & 0.12 & 0.00 & 0.00 & 0.00 \\
\hline 194.00 & 0.00 & 0.00 & 0.00 & 0.00 & 0.00 & 0.00 & 0.00 & 0.00 \\
\hline 201.00 & 0.00 & 0.00 & 0.00 & 0.00 & 0.00 & 0.00 & 0.00 & 0.00 \\
\hline 214.00 & 0.00 & 0.00 & 0.00 & 0.78 & 0.00 & 0.00 & 0.00 & 0.00 \\
\hline 228.00 & 0.00 & 0.00 & 0.00 & 0.00 & 0.00 & 0.00 & 0.00 & 0.00 \\
\hline 242.00 & 0.00 & 0.00 & 0.00 & 0.00 & 0.31 & 0.00 & 0.16 & 0.00 \\
\hline 249.00 & 0.00 & 0.18 & 0.00 & 0.18 & 0.36 & 0.00 & 0.00 & 0.00 \\
\hline 262.00 & 0.00 & 0.00 & 0.00 & 0.00 & 0.32 & 0.48 & 0.00 & 0.00 \\
\hline 277.00 & 0.00 & 0.14 & 0.00 & 0.14 & 0.54 & 0.00 & 0.27 & 0.00 \\
\hline 291.00 & 0.00 & 0.00 & 0.00 & 0.15 & 0.00 & 0.15 & 0.00 & 0.00 \\
\hline 305.00 & 0.00 & 0.33 & 0.00 & 0.00 & 0.33 & 0.00 & 0.00 & 0.00 \\
\hline 322.00 & 0.16 & 0.00 & 0.00 & 0.00 & 0.00 & 0.00 & 0.00 & 0.00 \\
\hline 336.00 & 0.15 & 0.00 & 0.00 & 0.15 & 0.00 & 0.00 & 0.00 & 0.00 \\
\hline 350.00 & 0.00 & 0.00 & 0.00 & 0.00 & 0.15 & 0.00 & 0.00 & 0.00 \\
\hline 356.00 & 0.00 & 0.00 & 0.00 & 0.30 & 0.00 & 0.00 & 0.00 & 0.00 \\
\hline 371.00 & 0.00 & 0.00 & 0.00 & 0.28 & 0.00 & 0.00 & 0.14 & 0.00 \\
\hline 385.00 & 0.00 & 0.00 & 0.00 & 0.55 & 0.00 & 0.00 & 0.00 & 0.00 \\
\hline 399.00 & 0.00 & 0.00 & 0.00 & 0.57 & 0.00 & 0.00 & 0.00 & 0.00 \\
\hline 413.00 & 0.00 & 0.00 & 0.00 & 0.00 & 0.12 & 0.00 & 0.00 & 0.12 \\
\hline 429.50 & 0.00 & 0.00 & 0.00 & 0.39 & 0.00 & 0.00 & 0.00 & 0.00 \\
\hline 443.50 & 0.00 & 0.00 & 0.00 & 0.13 & 0.00 & 0.00 & 0.00 & 0.00 \\
\hline 457.50 & 0.00 & 0.00 & 0.00 & 0.35 & 0.00 & 0.00 & 0.00 & 0.00 \\
\hline 471.50 & 0.00 & 0.00 & 0.00 & 0.00 & 0.00 & 0.00 & 0.00 & 0.00 \\
\hline 478.50 & 0.09 & 0.00 & 0.00 & 0.27 & 0.00 & 0.00 & 0.00 & 0.00 \\
\hline 497.50 & 0.00 & 0.00 & 0.00 & 0.00 & 0.00 & 0.00 & 0.00 & 0.00 \\
\hline
\end{tabular}




\begin{tabular}{|c|c|c|c|c|c|c|c|c|}
\hline \multicolumn{9}{|c|}{ Pollen Percent Abundance: Teapot Lake } \\
\hline \multirow{2}{*}{$\begin{array}{l}\text { Core } \\
\text { Depth } \\
\text { (cm) }\end{array}$} & \multicolumn{8}{|c|}{ Taxon } \\
\hline & $\begin{array}{c}\text { Zizania } \\
\text { aquatica }\end{array}$ & $\begin{array}{c}\text { Undifferentiated } \\
\text { Poaceae }\end{array}$ & Equisteum & Pteridium & Pteropsida & $\begin{array}{l}\text { Ulota } \\
\text { crispa }\end{array}$ & $\begin{array}{l}\text { Lycopodium } \\
\text { lucidulum }\end{array}$ & $\begin{array}{l}\text { Lycopodium } \\
\text { inundatum }\end{array}$ \\
\hline 8.00 & 0.00 & 0.00 & 0.00 & 0.00 & 0.22 & 0.00 & 0.00 & 0.00 \\
\hline 22.00 & 0.00 & 0.00 & 0.00 & 0.00 & 0.39 & 0.00 & 0.00 & 0.20 \\
\hline 36.00 & 0.26 & 0.51 & 0.00 & 0.00 & 0.51 & 0.00 & 0.00 & 0.00 \\
\hline 43.00 & 0.24 & 0.00 & 0.00 & 0.00 & 0.24 & 0.00 & 0.00 & 0.00 \\
\hline 50.00 & 0.27 & 0.00 & 0.00 & 0.00 & 0.00 & 0.00 & 0.00 & 0.00 \\
\hline 64.00 & 0.55 & 0.00 & 0.00 & 0.00 & 0.27 & 0.00 & 0.00 & 0.00 \\
\hline 78.00 & 0.00 & 0.00 & 0.00 & 0.00 & 2.62 & 0.00 & 0.00 & 0.00 \\
\hline 92.00 & 0.00 & 0.00 & 0.00 & 0.22 & 0.67 & 0.00 & 0.00 & 0.00 \\
\hline 99.00 & 0.00 & 0.00 & 0.00 & 0.40 & 1.00 & 0.00 & 0.00 & 0.00 \\
\hline 107.00 & 0.00 & 0.00 & 0.00 & 0.00 & 0.73 & 0.00 & 0.00 & 0.00 \\
\hline 110.00 & 0.00 & 0.27 & 0.53 & 0.27 & 0.00 & 0.00 & 0.00 & 0.00 \\
\hline 117.00 & 0.00 & 0.24 & 0.00 & 0.00 & 0.24 & 0.00 & 0.00 & 0.00 \\
\hline 131.00 & 0.00 & 0.00 & 0.00 & 0.00 & 0.78 & 0.00 & 0.00 & 0.00 \\
\hline 138.00 & 0.00 & 0.00 & 0.00 & 0.00 & 1.15 & 0.00 & 0.00 & 0.00 \\
\hline 152.00 & 0.00 & 0.40 & 0.00 & 0.00 & 0.20 & 0.00 & 0.00 & 0.00 \\
\hline 166.00 & 0.00 & 0.00 & 0.00 & 0.00 & 1.42 & 0.00 & 0.00 & 0.00 \\
\hline 180.00 & 0.00 & 0.00 & 0.00 & 0.00 & 0.98 & 0.00 & 0.00 & 0.00 \\
\hline 187.00 & 0.00 & 0.00 & 0.00 & 0.00 & 0.12 & 0.00 & 0.00 & 0.00 \\
\hline 194.00 & 0.00 & 0.00 & 0.00 & 0.00 & 1.15 & 0.00 & 0.00 & 0.00 \\
\hline 201.00 & 0.00 & 0.00 & 0.00 & 0.00 & 1.13 & 0.00 & 0.00 & 0.00 \\
\hline 214.00 & 0.00 & 0.00 & 0.00 & 0.13 & 0.92 & 0.00 & 0.13 & 0.00 \\
\hline 228.00 & 0.00 & 0.16 & 0.00 & 0.00 & 0.32 & 0.00 & 0.00 & 0.00 \\
\hline 242.00 & 0.31 & 0.00 & 0.00 & 0.00 & 1.40 & 0.00 & 0.00 & 0.00 \\
\hline 249.00 & 0.00 & 0.00 & 0.00 & 0.00 & 1.08 & 0.36 & 0.00 & 0.00 \\
\hline 262.00 & 0.00 & 0.00 & 0.00 & 0.00 & 0.00 & 0.00 & 0.00 & 0.00 \\
\hline 277.00 & 0.00 & 0.00 & 0.00 & 0.14 & 0.00 & 0.00 & 0.00 & 0.00 \\
\hline 291.00 & 0.00 & 0.00 & 0.00 & 0.00 & 0.15 & 0.00 & 0.00 & 0.00 \\
\hline 305.00 & 0.16 & 0.00 & 0.00 & 0.00 & 1.15 & 0.00 & 0.00 & 0.00 \\
\hline 322.00 & 0.00 & 0.00 & 0.00 & 0.00 & 0.47 & 0.00 & 0.00 & 0.00 \\
\hline 336.00 & 0.00 & 0.00 & 0.00 & 0.00 & 0.30 & 0.00 & 0.00 & 0.00 \\
\hline 350.00 & 0.00 & 0.00 & 0.00 & 0.00 & 1.68 & 0.00 & 0.00 & 0.00 \\
\hline 356.00 & 0.00 & 0.00 & 0.00 & 0.00 & 0.15 & 0.00 & 0.00 & 0.00 \\
\hline 371.00 & 0.00 & 0.28 & 0.00 & 0.00 & 0.42 & 0.00 & 0.00 & 0.00 \\
\hline 385.00 & 0.00 & 0.00 & 0.00 & 0.00 & 0.27 & 0.00 & 0.00 & 0.00 \\
\hline 399.00 & 0.14 & 0.00 & 0.00 & 0.00 & 0.00 & 0.00 & 0.00 & 0.00 \\
\hline 413.00 & 0.00 & 0.00 & 0.00 & 0.00 & 0.00 & 0.00 & 0.00 & 0.00 \\
\hline 429.50 & 0.00 & 0.13 & 0.00 & 0.00 & 0.00 & 0.00 & 0.00 & 0.00 \\
\hline 443.50 & 0.00 & 0.25 & 0.00 & 0.00 & 0.13 & 0.00 & 0.00 & 0.00 \\
\hline 457.50 & 0.00 & 0.00 & 0.00 & 0.00 & 0.12 & 0.00 & 0.00 & 0.00 \\
\hline 471.50 & 0.00 & 0.00 & 0.00 & 0.00 & 0.33 & 0.00 & 0.00 & 0.00 \\
\hline 478.50 & 0.00 & 0.00 & 0.00 & 0.00 & 0.00 & 0.00 & 0.00 & 0.00 \\
\hline 497.50 & 0.00 & 0.12 & 0.00 & 0.00 & 0.12 & 0.00 & 0.00 & 0.00 \\
\hline
\end{tabular}




\begin{tabular}{|c|c|c|c|c|c|c|c|c|}
\hline \multicolumn{9}{|c|}{ Pollen Percent Abundance: Teapot Lake } \\
\hline \multirow{2}{*}{$\begin{array}{l}\text { Core } \\
\text { Depth } \\
\text { (cm) }\end{array}$} & \multicolumn{8}{|c|}{ Taxon } \\
\hline & $\begin{array}{c}\text { Other/ } \\
\text { Unkown }\end{array}$ & $\begin{array}{l}\text { Potamogeton } \\
\text { pentin }\end{array}$ & $\begin{array}{l}\text { Potamogeton } \\
\text { natans }\end{array}$ & Nuphar & Cyperaceae & Nymphaea & Typha & Charcoal \\
\hline 8.00 & 11.18 & 0.00 & 0.00 & 0.00 & 0.00 & 0.00 & 0.00 & 0.00 \\
\hline 22.00 & 12.35 & 0.00 & 0.58 & 0.00 & 0.00 & 0.00 & 0.77 & 5.49 \\
\hline 36.00 & 14.65 & 0.00 & 0.25 & 0.25 & 0.25 & 0.00 & 1.01 & 0.77 \\
\hline 43.00 & 7.76 & 0.00 & 0.00 & 0.23 & 0.00 & 0.23 & 0.00 & 6.12 \\
\hline 50.00 & 8.06 & 0.00 & 0.00 & 0.00 & 0.00 & 0.00 & 0.00 & 4.84 \\
\hline 64.00 & 10.11 & 0.00 & 0.00 & 0.00 & 0.00 & 0.00 & 0.00 & 11.20 \\
\hline 78.00 & 7.33 & 0.00 & 0.00 & 0.00 & 0.00 & 0.00 & 0.00 & 14.92 \\
\hline 92.00 & 9.31 & 0.00 & 2.16 & 0.22 & 0.22 & 0.00 & 0.00 & 9.09 \\
\hline 99.00 & 9.24 & 0.00 & 0.60 & 0.00 & 0.00 & 0.00 & 0.00 & 8.84 \\
\hline 107.00 & 3.88 & 0.00 & 0.00 & 0.00 & 0.24 & 0.00 & 0.00 & 26.70 \\
\hline 110.00 & 6.95 & 0.00 & 0.00 & 0.00 & 0.00 & 0.00 & 0.00 & 9.36 \\
\hline 117.00 & 3.53 & 0.00 & 0.00 & 0.00 & 0.00 & 0.70 & 0.00 & 18.12 \\
\hline 131.00 & 9.34 & 0.00 & 0.00 & 0.00 & 0.00 & 0.00 & 0.00 & 5.84 \\
\hline 138.00 & 6.73 & 0.00 & 0.00 & 0.57 & 0.00 & 0.00 & 0.76 & 6.73 \\
\hline 152.00 & 5.44 & 0.00 & 0.00 & 0.00 & 0.00 & 0.00 & 0.00 & 3.43 \\
\hline 166.00 & 10.12 & 0.00 & 0.20 & 0.00 & 0.00 & 0.00 & 0.20 & 11.74 \\
\hline 180.00 & 9.59 & 0.00 & 0.00 & 0.20 & 0.00 & 0.00 & 0.00 & 31.31 \\
\hline 187.00 & 4.28 & 0.00 & 0.12 & 0.00 & 0.00 & 0.00 & 0.00 & 3.35 \\
\hline 194.00 & 8.62 & 0.00 & 0.00 & 0.00 & 0.29 & 0.00 & 0.00 & 17.53 \\
\hline 201.00 & 6.40 & 0.00 & 0.00 & 0.00 & 0.00 & 0.00 & 0.00 & 3.39 \\
\hline 214.00 & 6.93 & 0.00 & 0.00 & 0.13 & 0.00 & 0.00 & 0.00 & 3.53 \\
\hline 228.00 & 5.83 & 0.00 & 0.00 & 0.00 & 0.32 & 0.00 & 0.32 & 10.37 \\
\hline 242.00 & 6.55 & 0.00 & 0.00 & 0.46 & 0.15 & 0.15 & 0.00 & 3.28 \\
\hline 249.00 & 15.32 & 0.35 & 1.24 & 0.18 & 0.00 & 0.00 & 0.00 & 10.63 \\
\hline 262.00 & 6.09 & 0.00 & 0.00 & 0.00 & 0.00 & 0.16 & 0.00 & 5.29 \\
\hline 277.00 & 4.21 & 0.00 & 0.00 & 0.27 & 1.20 & 0.00 & 0.00 & 1.63 \\
\hline 291.00 & 1.85 & 0.00 & 0.00 & 0.15 & 1.07 & 0.00 & 0.00 & 2.62 \\
\hline 305.00 & 10.53 & 0.00 & 0.00 & 0.00 & 0.00 & 0.00 & 0.00 & 1.81 \\
\hline 322.00 & 5.63 & 0.00 & 0.00 & 0.00 & 0.00 & 0.00 & 0.00 & 1.41 \\
\hline 336.00 & 8.18 & 0.00 & 0.00 & 0.00 & 0.00 & 0.00 & 0.00 & 1.52 \\
\hline 350.00 & 4.27 & 0.00 & 0.00 & 0.00 & 0.00 & 0.15 & 0.00 & 1.07 \\
\hline 356.00 & 7.55 & 0.00 & 0.00 & 0.15 & 0.00 & 0.00 & 0.00 & 0.76 \\
\hline 371.00 & 2.93 & 0.14 & 0.00 & 0.00 & 0.00 & 0.00 & 0.00 & 1.26 \\
\hline 385.00 & 4.91 & 0.00 & 0.27 & 0.00 & 0.00 & 0.00 & 0.00 & 0.68 \\
\hline 399.00 & 3.41 & 0.00 & 0.00 & 0.00 & 0.00 & 0.00 & 0.00 & 0.28 \\
\hline 413.00 & 1.62 & 0.00 & 0.00 & 0.00 & 0.00 & 0.12 & 0.00 & 0.00 \\
\hline 429.50 & 2.76 & 0.00 & 0.00 & 0.00 & 0.00 & 0.00 & 0.00 & 0.39 \\
\hline 443.50 & 2.29 & 0.00 & 0.00 & 0.00 & 0.00 & 0.00 & 0.00 & 0.25 \\
\hline 457.50 & 1.28 & 0.00 & 0.00 & 0.00 & 0.12 & 0.00 & 0.00 & 0.12 \\
\hline 471.50 & 2.19 & 0.00 & 0.00 & 0.00 & 0.00 & 0.00 & 0.00 & 0.22 \\
\hline 478.50 & 3.20 & 0.00 & 0.00 & 0.09 & 0.18 & 0.00 & 0.00 & 0.91 \\
\hline 497.50 & 1.70 & 0.00 & 0.00 & 0.00 & 0.00 & 0.00 & 0.00 & 0.24 \\
\hline
\end{tabular}




\begin{tabular}{|l|c|c|c|c|c|}
\hline \multicolumn{7}{|c|}{ Pollen Percent Abundance: Teapot Lake } \\
\hline Core & \multicolumn{5}{|c|}{ Taxon } \\
\cline { 2 - 6 } Depth \\
(cm) & $\begin{array}{c}\text { Nymphaea } \\
\text { hairs }\end{array}$ & $\begin{array}{c}\text { Tilletia } \\
\text { caries }\end{array}$ & Ustilago & Pediastrum & Spicules \\
\hline 8.00 & 0.00 & 0.00 & 0.44 & 0.00 & 0.00 \\
22.00 & 0.00 & 0.00 & 0.00 & 0.20 & 5.10 \\
36.00 & 0.00 & 0.00 & 0.00 & 0.26 & 8.23 \\
43.00 & 0.00 & 0.00 & 0.00 & 0.00 & 8.00 \\
50.00 & 0.00 & 0.00 & 0.27 & 0.00 & 5.38 \\
64.00 & 0.00 & 0.00 & 0.00 & 0.00 & 8.20 \\
78.00 & 0.00 & 0.00 & 0.00 & 0.00 & 10.47 \\
92.00 & 0.00 & 0.00 & 0.00 & 0.00 & 2.66 \\
99.00 & 0.00 & 1.00 & 0.00 & 0.00 & 5.02 \\
107.00 & 0.00 & 0.49 & 0.00 & 0.00 & 6.31 \\
110.00 & 0.00 & 0.00 & 0.00 & 0.00 & 6.95 \\
117.00 & 0.24 & 0.00 & 0.00 & 0.00 & 1.18 \\
131.00 & 0.00 & 0.00 & 0.00 & 0.00 & 0.39 \\
138.00 & 0.00 & 0.00 & 0.00 & 0.00 & 0.19 \\
152.00 & 0.00 & 0.00 & 0.00 & 0.00 & 0.00 \\
166.00 & 0.00 & 0.00 & 0.00 & 0.00 & 0.20 \\
180.00 & 0.00 & 0.00 & 0.00 & 0.00 & 0.20 \\
187.00 & 0.12 & 0.58 & 0.00 & 0.00 & 0.00 \\
194.00 & 0.00 & 0.00 & 0.00 & 0.00 & 0.00 \\
201.00 & 0.00 & 0.00 & 0.00 & 0.00 & 0.19 \\
214.00 & 0.13 & 0.00 & 0.00 & 0.00 & 0.26 \\
228.00 & 0.16 & 0.16 & 0.00 & 0.00 & 0.32 \\
242.00 & 0.00 & 0.00 & 0.00 & 0.00 & 0.00 \\
249.00 & 0.00 & 0.00 & 0.00 & 0.00 & 0.18 \\
262.00 & 0.00 & 0.32 & 0.00 & 0.00 & 0.16 \\
277.00 & 0.00 & 0.00 & 0.00 & 0.27 & 1.63 \\
291.00 & 0.00 & 0.15 & 0.00 & 0.00 & 4.48 \\
305.00 & 0.00 & 0.00 & 0.00 & 0.00 & 0.33 \\
322.00 & 0.00 & 0.16 & 0.00 & 0.00 & 0.31 \\
336.00 & 0.00 & 0.00 & 0.00 & 0.00 & 2.27 \\
350.00 & 1.07 & 0.15 & 0.00 & 0.15 & 0.46 \\
356.00 & 0.00 & 0.30 & 0.00 & 0.00 & 1.81 \\
371.00 & 0.00 & 0.42 & 0.00 & 0.14 & 9.92 \\
385.00 & 0.00 & 0.00 & 0.00 & 0.00 & 0.27 \\
399.00 & 0.00 & 0.14 & 0.00 & 0.00 & 3.98 \\
413.00 & 0.00 & 0.00 & 0.00 & 0.00 & 6.00 \\
429.50 & 0.00 & 0.00 & 0.00 & 0.00 & 0.26 \\
443.50 & 0.00 & 0.13 & 0.00 & 0.00 & 0.76 \\
457.50 & 0.00 & 0.12 & 0.00 & 0.00 & 0.35 \\
471.50 & 0.00 & 0.00 & 0.00 & 0.00 & 1.53 \\
478.50 & 0.09 & 1.55 & 0.00 & 0.18 & 0.27 \\
497.50 & 0.00 & 0.24 & 0.00 & 0.00 & 0.61 \\
\hline
\end{tabular}




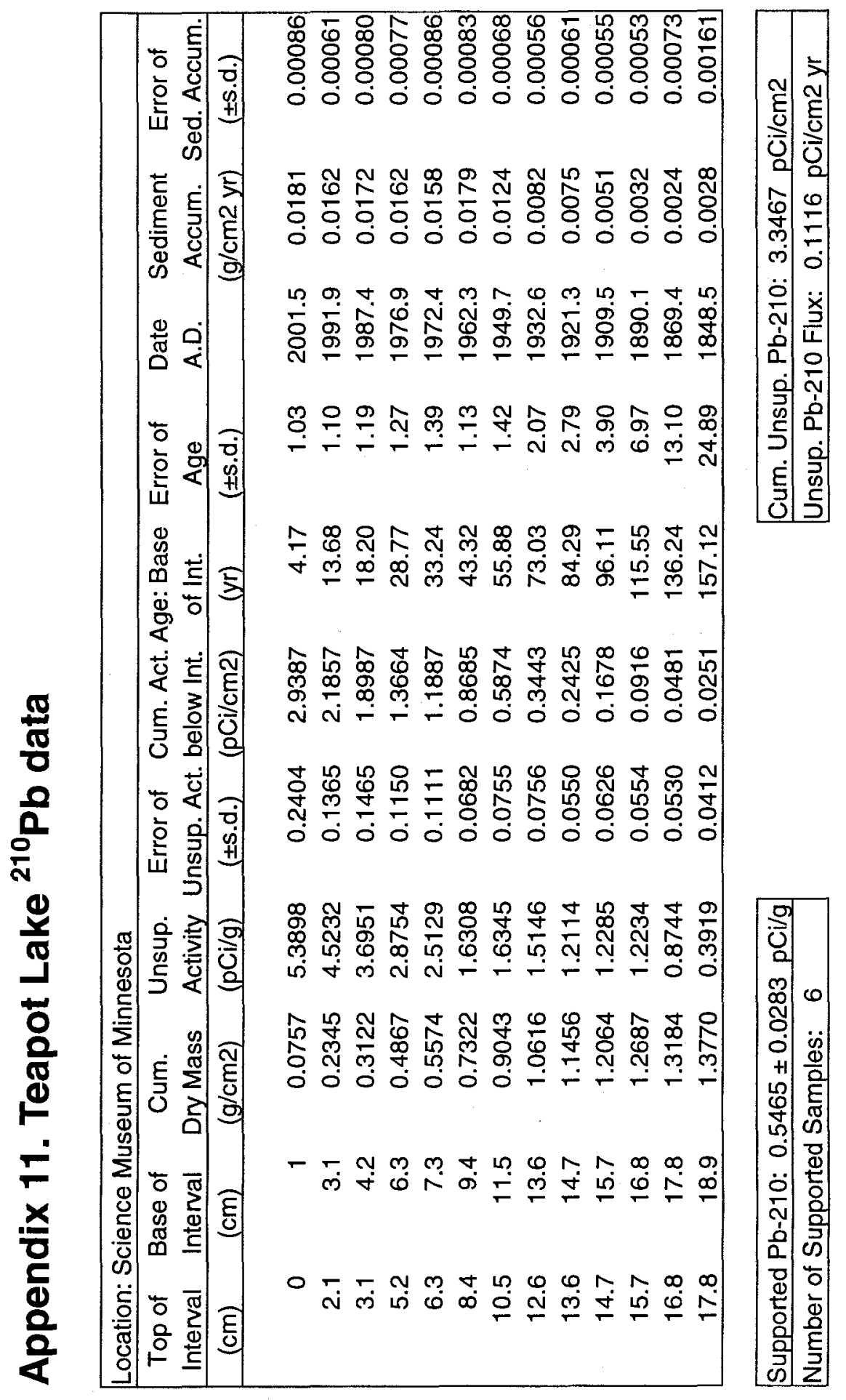




\section{Appendix 12. Common diatom species images: Teapot Lake, Ontario}

These images, as well as subsample material and microscope slides, are archived at the Canadian Museum of Nature, Research Division, Ottawa, Ontario.

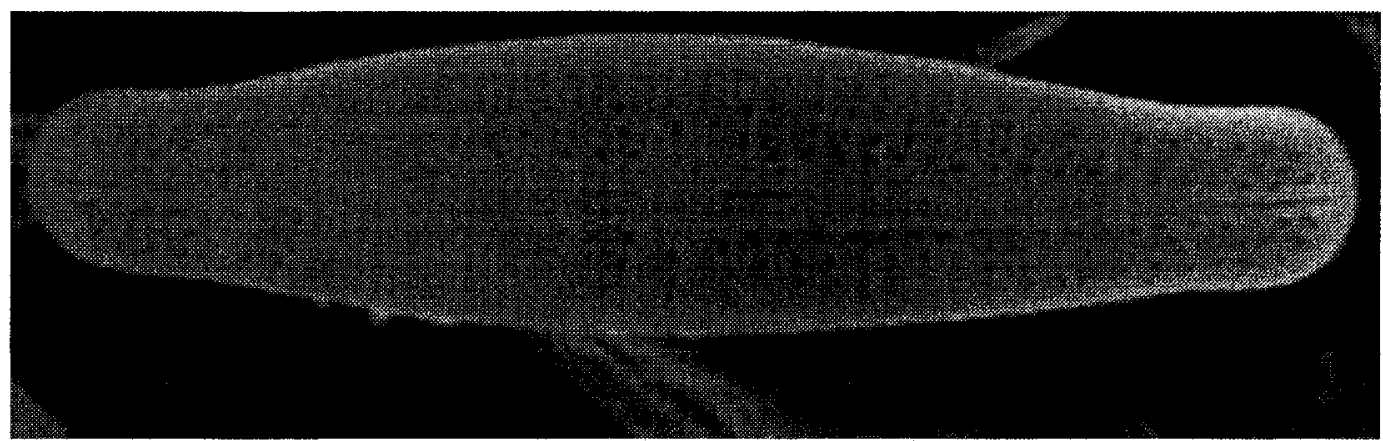

Achnanthidium minutissimum var. minutissimum

Core Depth: $410 \mathrm{~cm}$

Length: $11 \mu \mathrm{m}$; Width: $2.66 \mu \mathrm{m}$

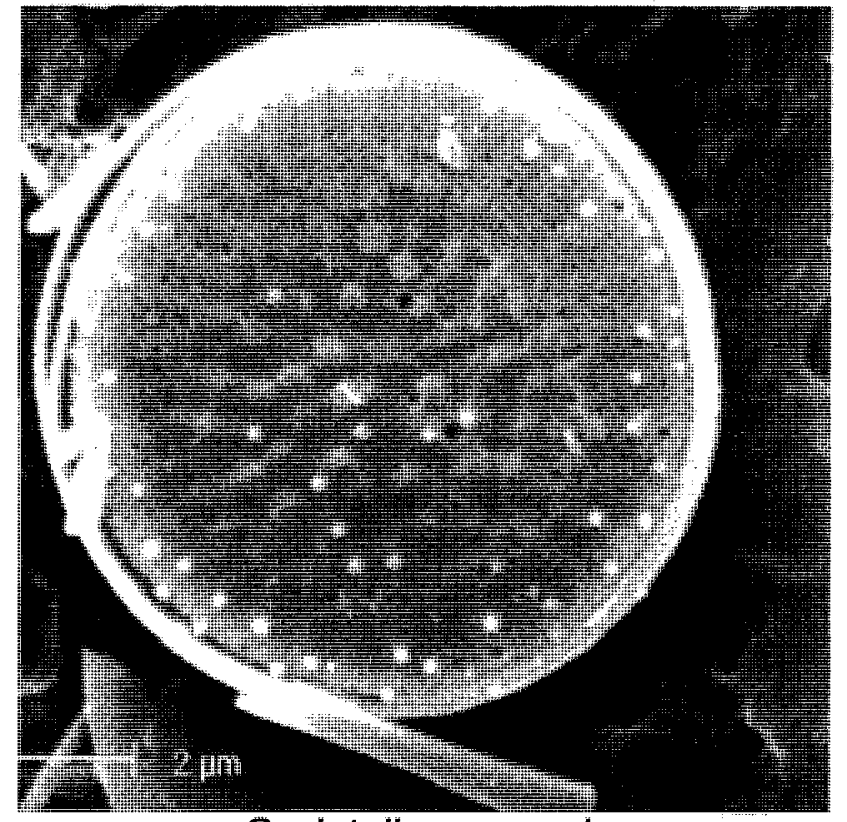

Cyclotella comensis

Core Depth: $410 \mathrm{~cm}$

Length: $6.23 \mu \mathrm{m}$; Width: $6.23 \mu \mathrm{m}$ 


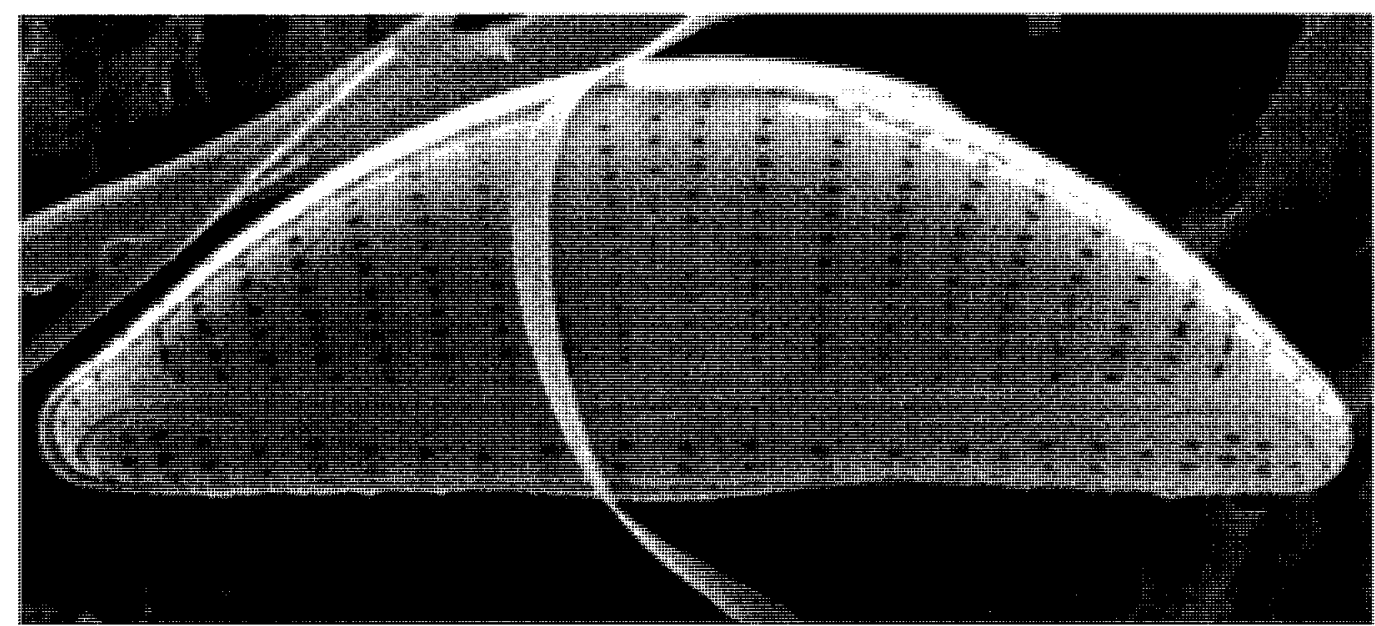

Encyonema minuta

Core Depth: $10 \mathrm{~cm}$

Length: $13.8 \mu \mathrm{m}$; Width: $4.58 \mu \mathrm{m}$

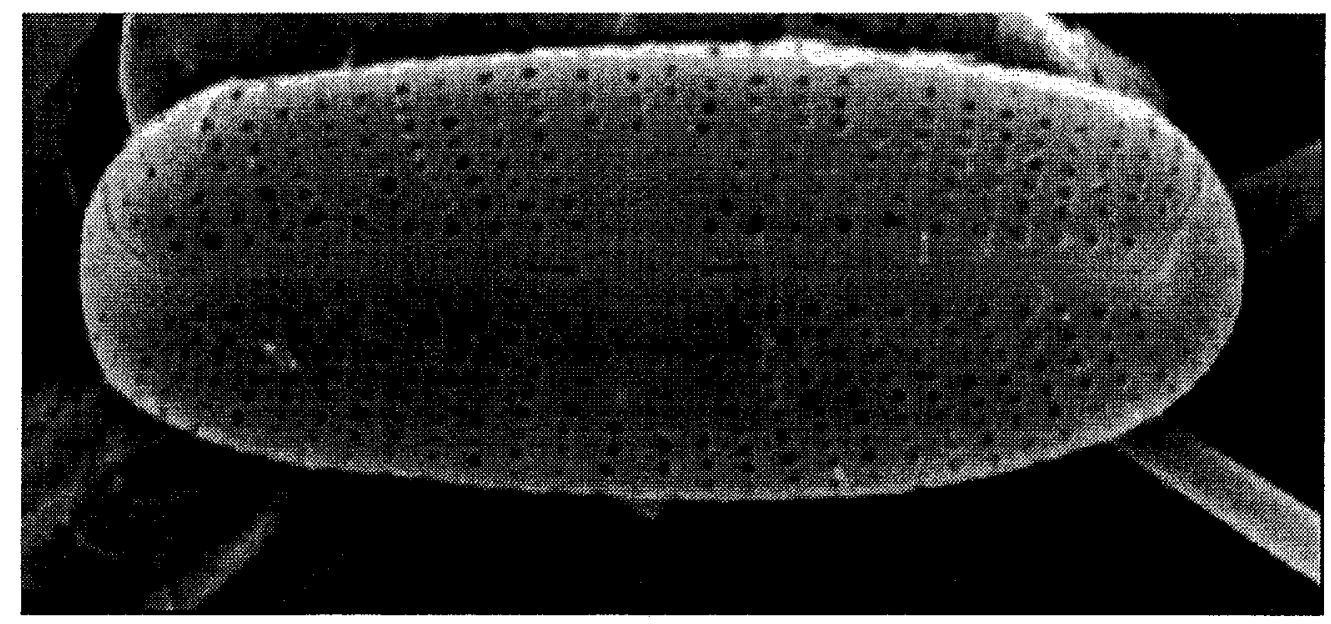

Cf. Eolimna minima

Core Depth: $410 \mathrm{~cm}$

Length: $9.33 \mu \mathrm{m}$; Width: $3.77 \mu \mathrm{m}$ 


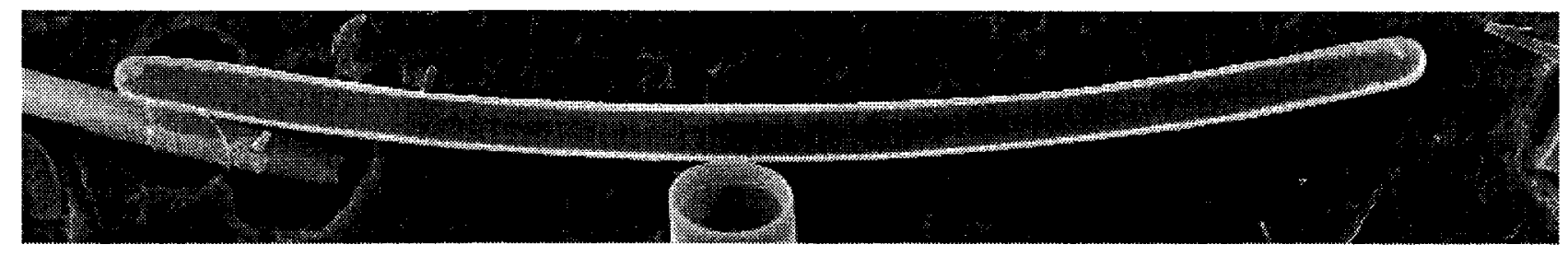

Eunotia flexuosa

Core Depth: $10 \mathrm{~cm}$

Length: $74.7 \mu \mathrm{m}$; Width: $3.61 \mu \mathrm{m}$

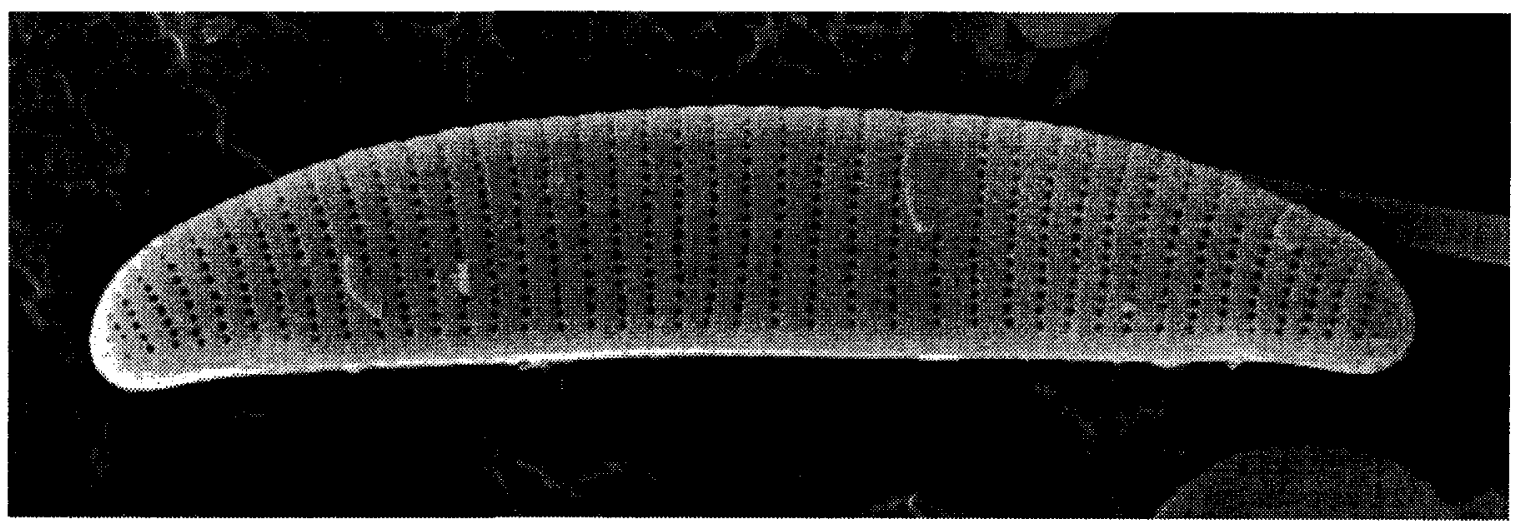

Eunotia incisa

Core Depth: $10 \mathrm{~cm}$

Length: $19.2 \mu \mathrm{m}$; Width: $3.73 \mu \mathrm{m}$

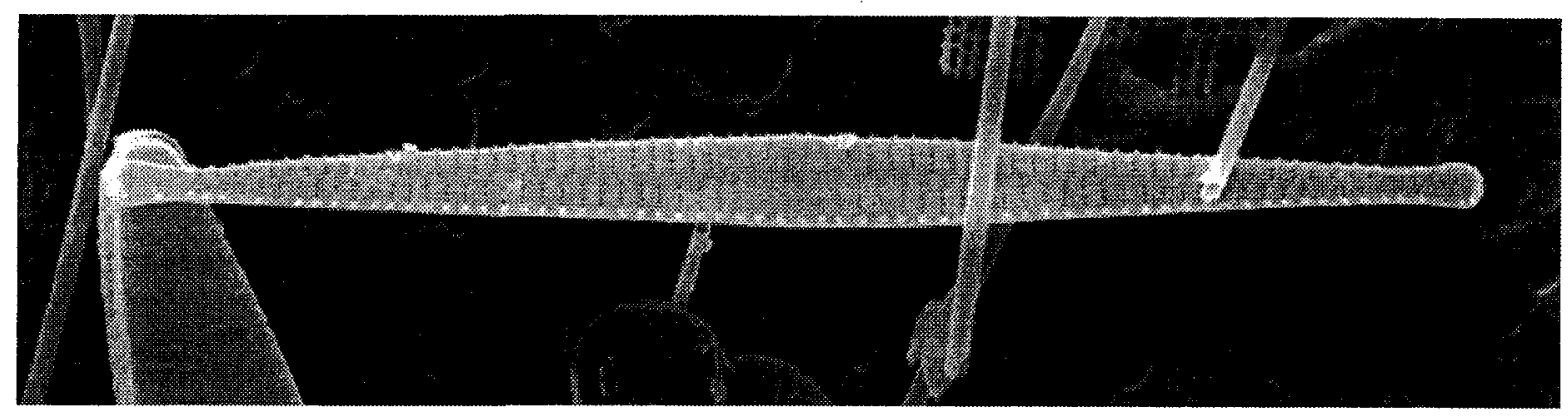

Fragilaria tenera

Core Depth: $10 \mathrm{~cm}$

Length: $34.5 \mu \mathrm{m}$; Width: $2.25 \mu \mathrm{m}$ 


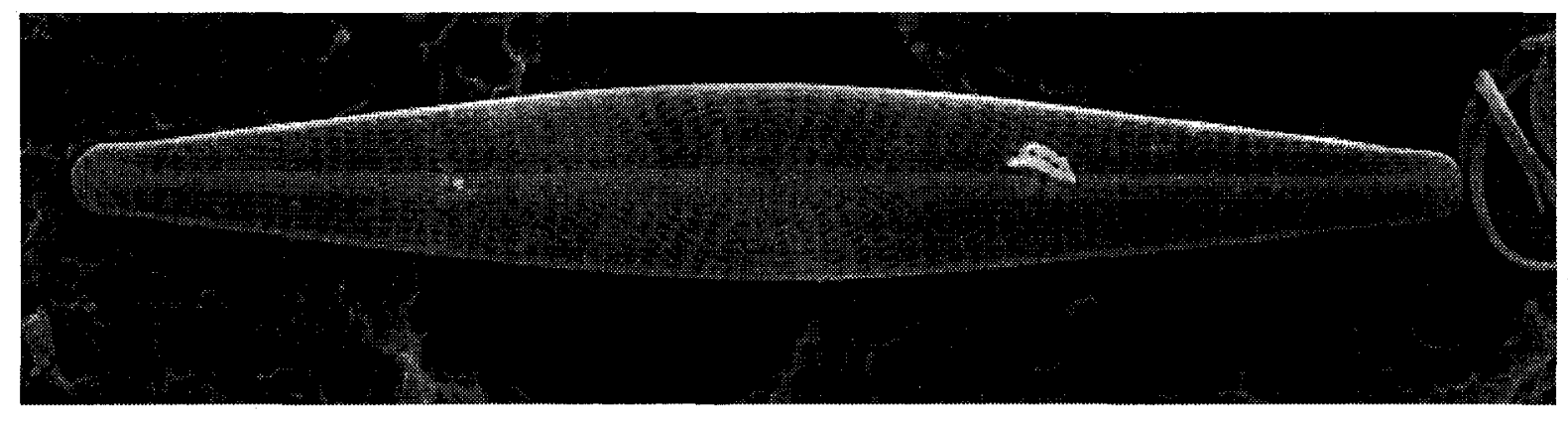

Navicula radiosa

Core Depth: $10 \mathrm{~cm}$

Length: $39.1 \mu \mathrm{m}$; Width: $5.72 \mu \mathrm{m}$

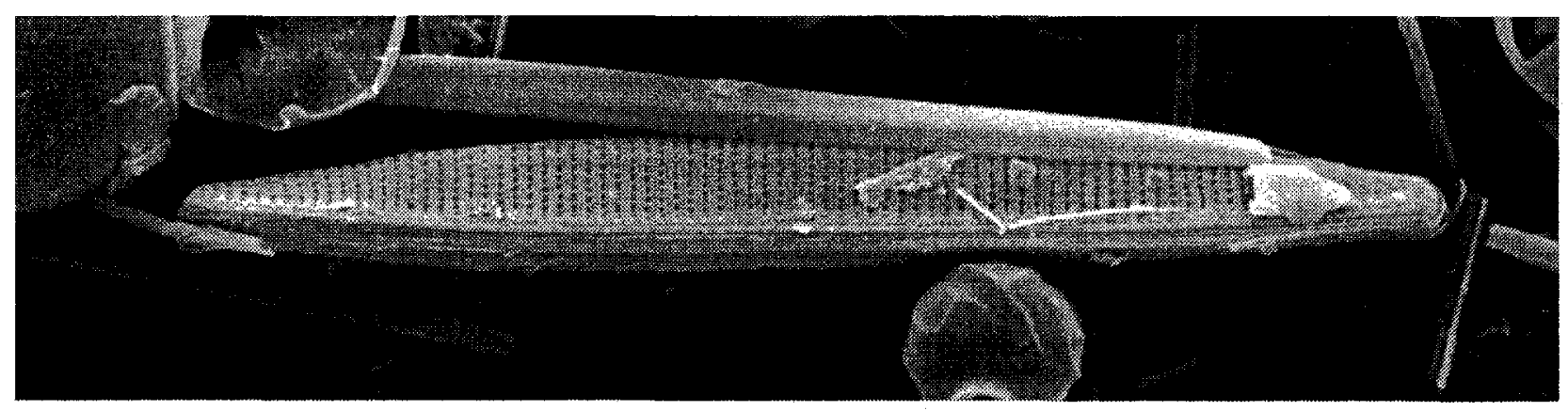

Nitzschia perminuta

Core Depth: $410 \mathrm{~cm}$

Length: $26.6 \mu \mathrm{m}$; Width: $2.87 \mu \mathrm{m}$ 


\section{Appendix 13. Sediment core x-ray images: Teapot Lake, Ontario}

Note: The images below are those not included within the text. The top direction is all of these images is to the left.

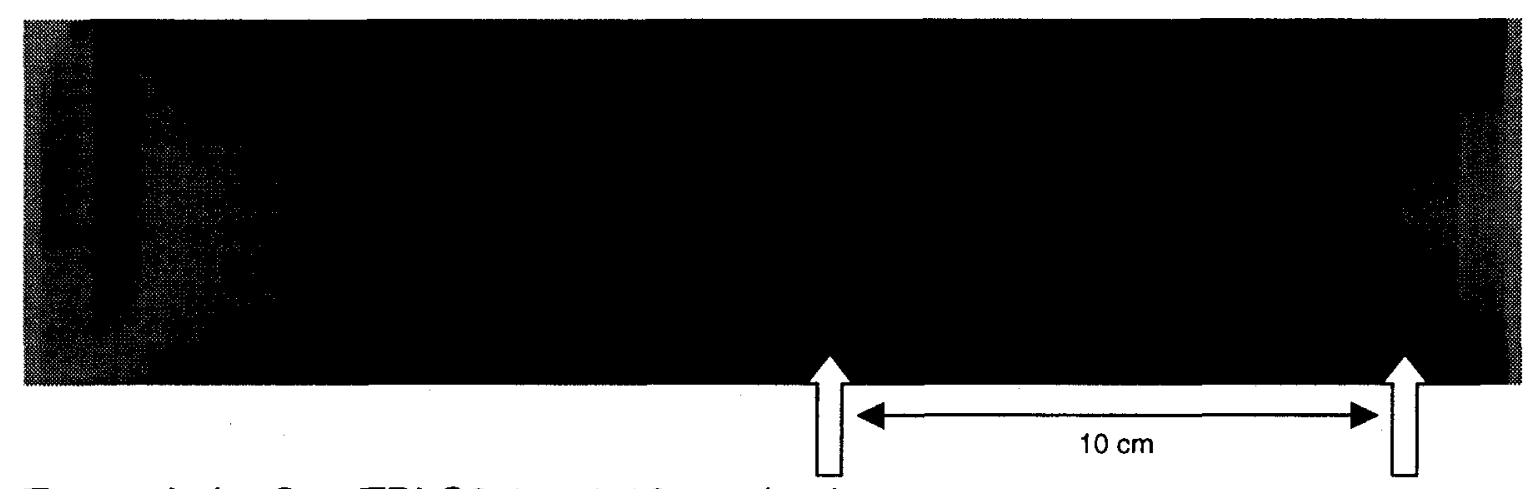

Teapot Lake CoreTPLC2-1: 0-20 cm depth

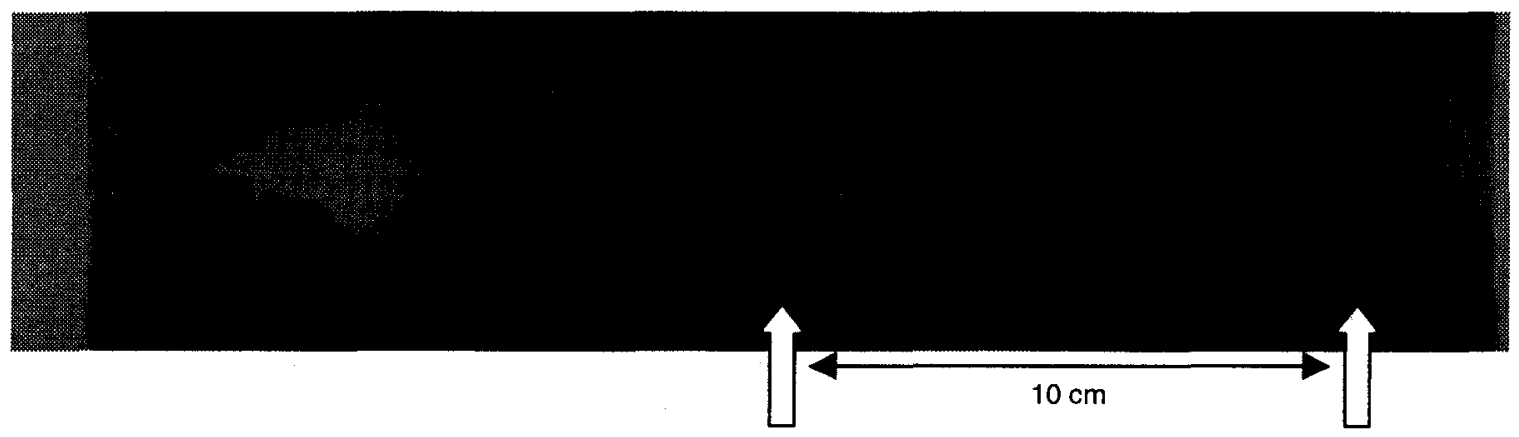

Teapot Lake Core TPLC2-1: 40-60 cm depth 


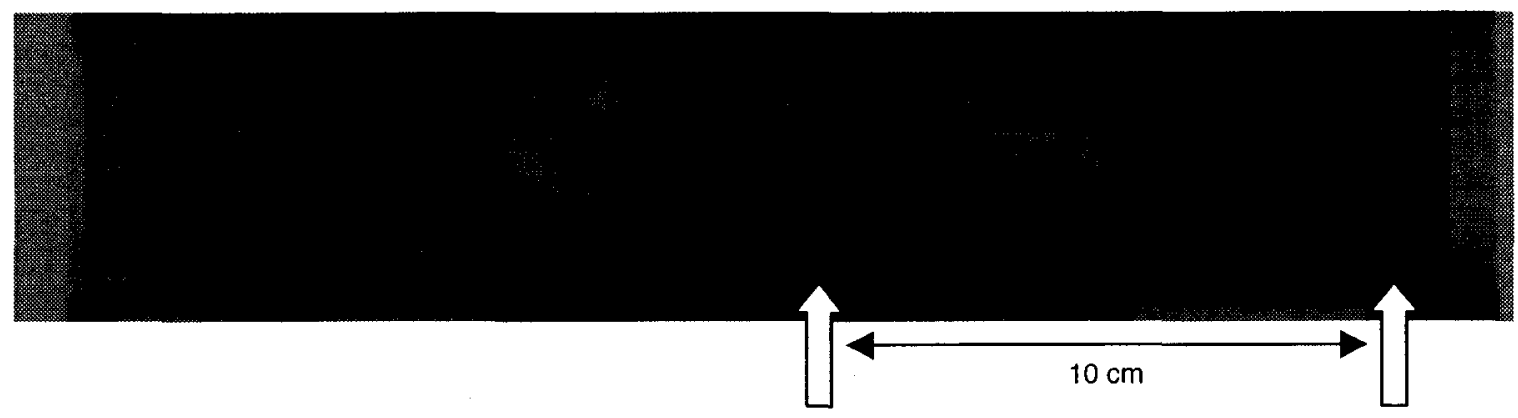

Teapot Lake CoreTPLC2-1: 60-80 cm depth

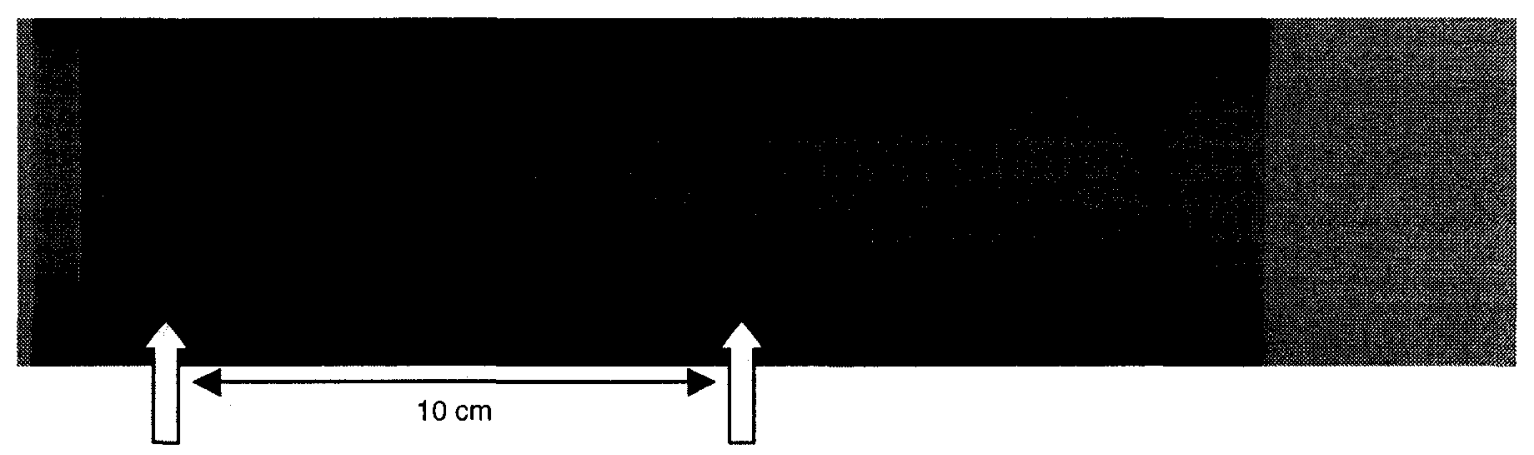

Teapot Lake Core TPLC2-1: 80-100 cm depth

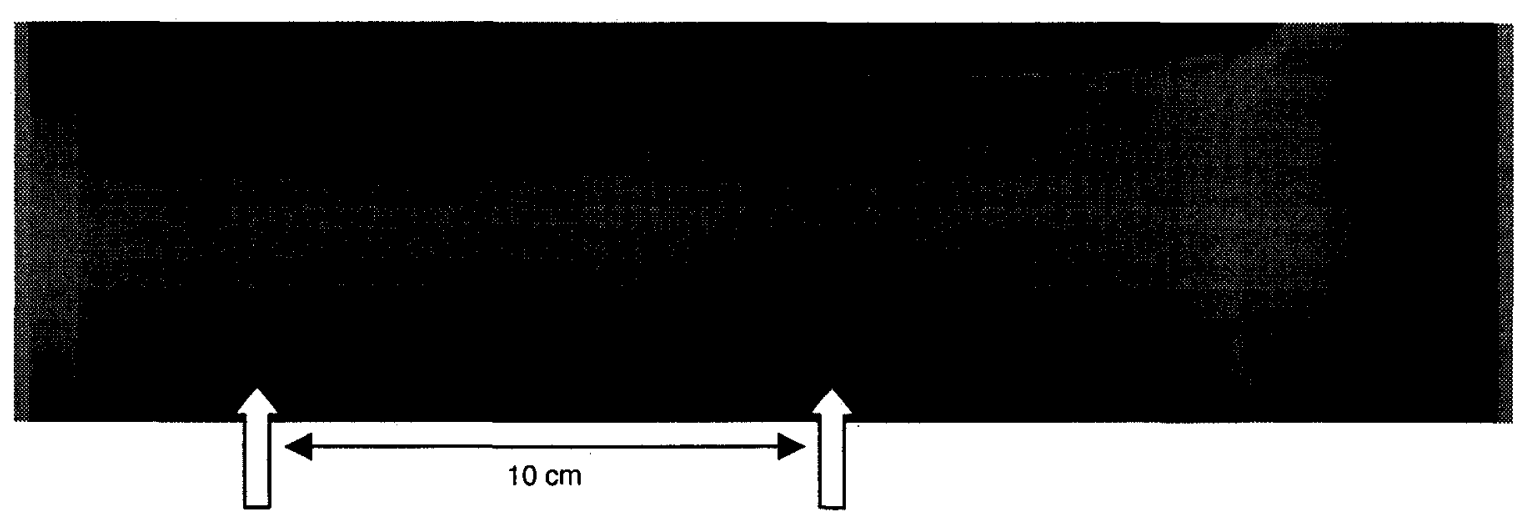

Teapot Lake Core TPLC2-1: 90-110 cm depth 


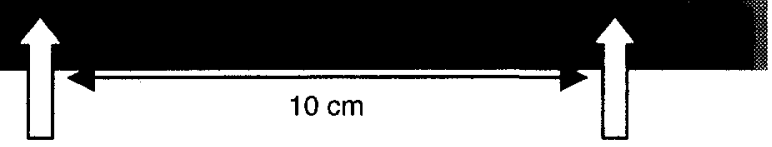

Teapot Lake CoreTPLC2-2: 110-130 cm depth

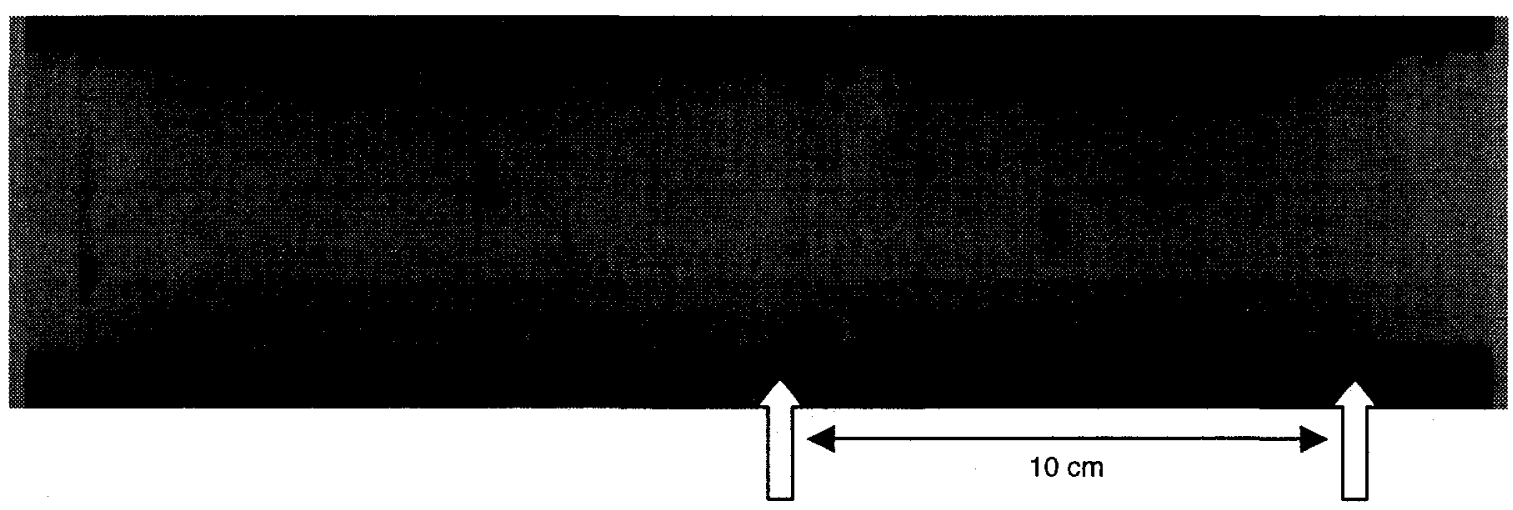

Teapot Lake Core TPLC2-2: 150-170 cm depth

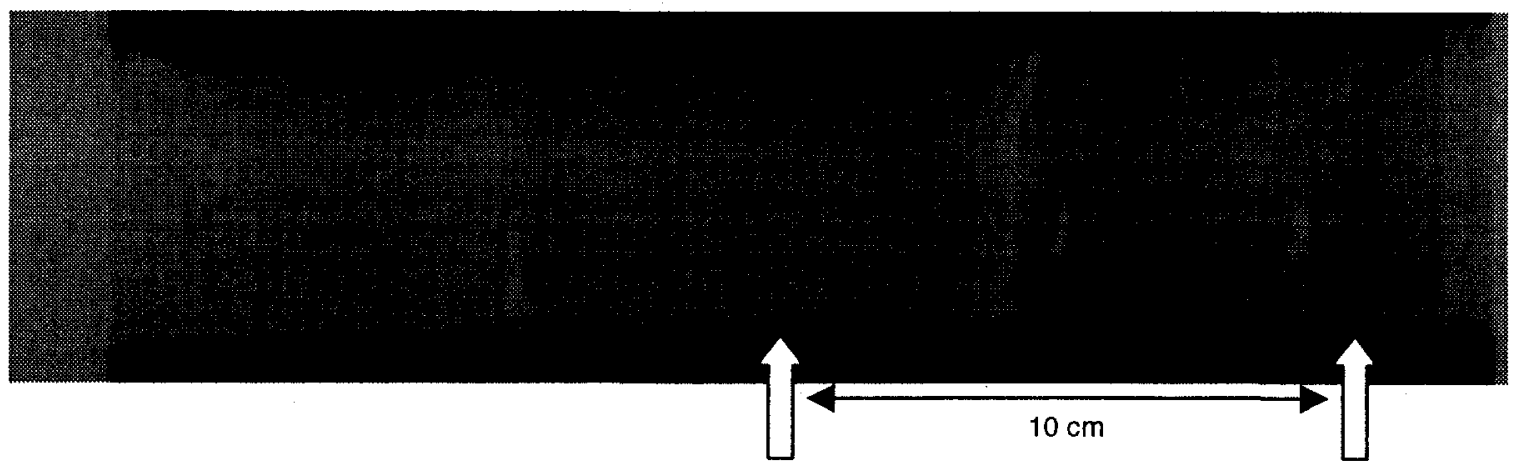

Teapot Lake Core TPLC2-2: 170-190 cm depth 


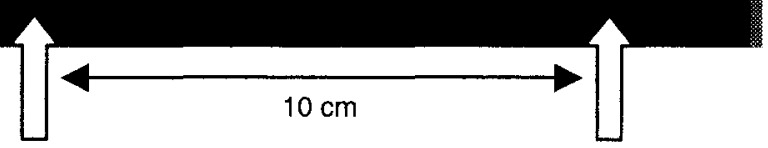

Teapot Lake Core TPLC2-3: 206-226 cm depth

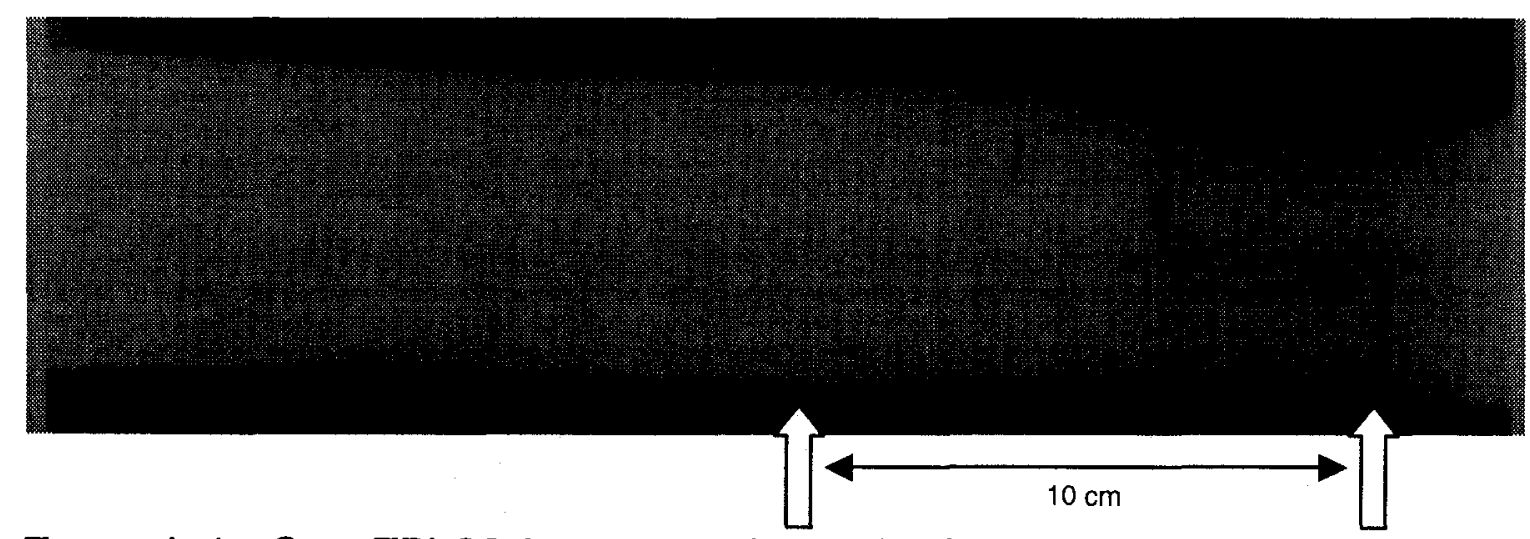

Teapot Lake Core TPLC2-3: 226 - 246 cm depth

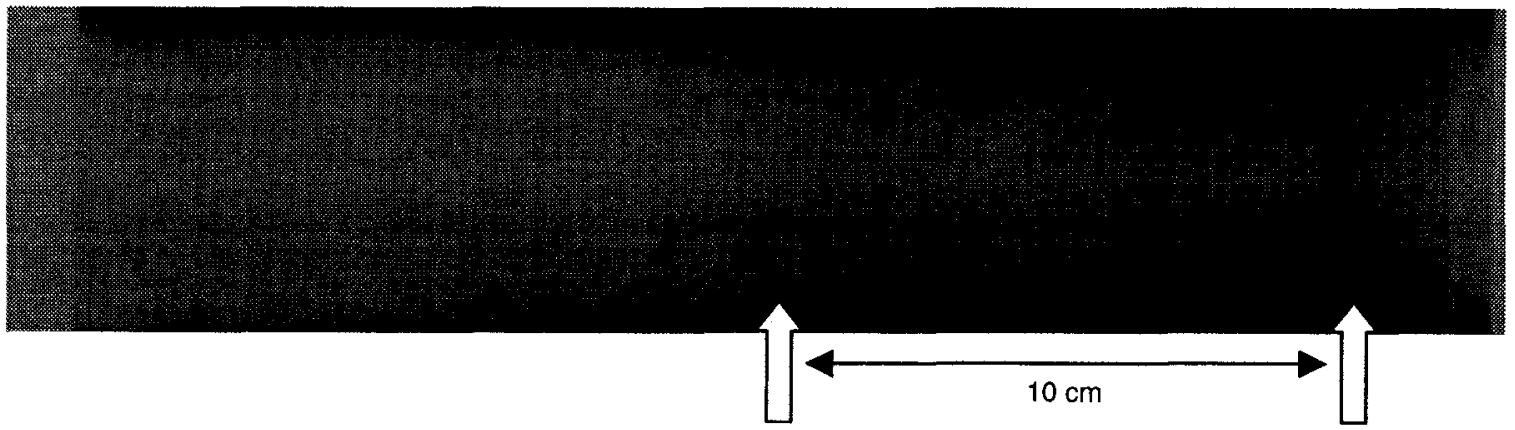

Teapot Lake Core TPLC2-3: $~ 246-266 \mathrm{~cm}$ depth 


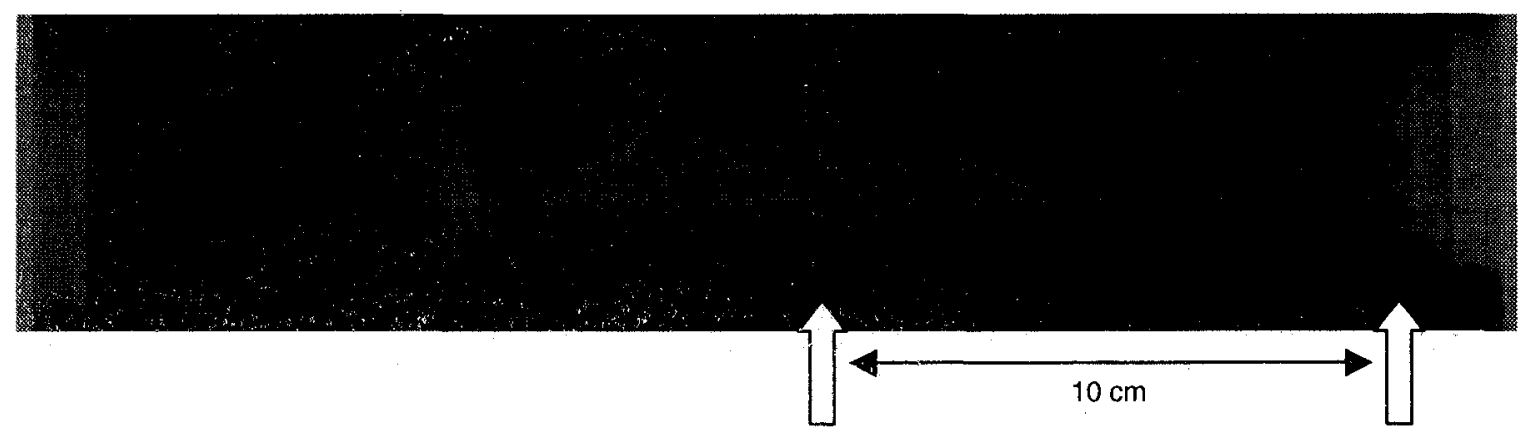

Teapot Lake Core TPLC2-3: 266 - $286 \mathrm{~cm}$ depth

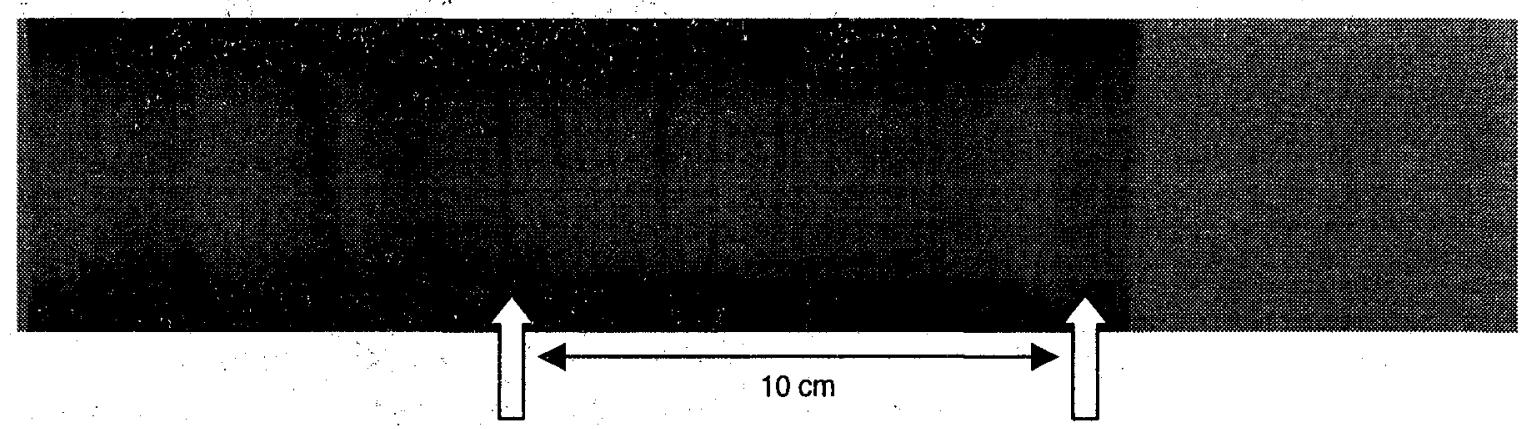

Teapot Lake Core TPL.C2-3: 287-307 cm depth

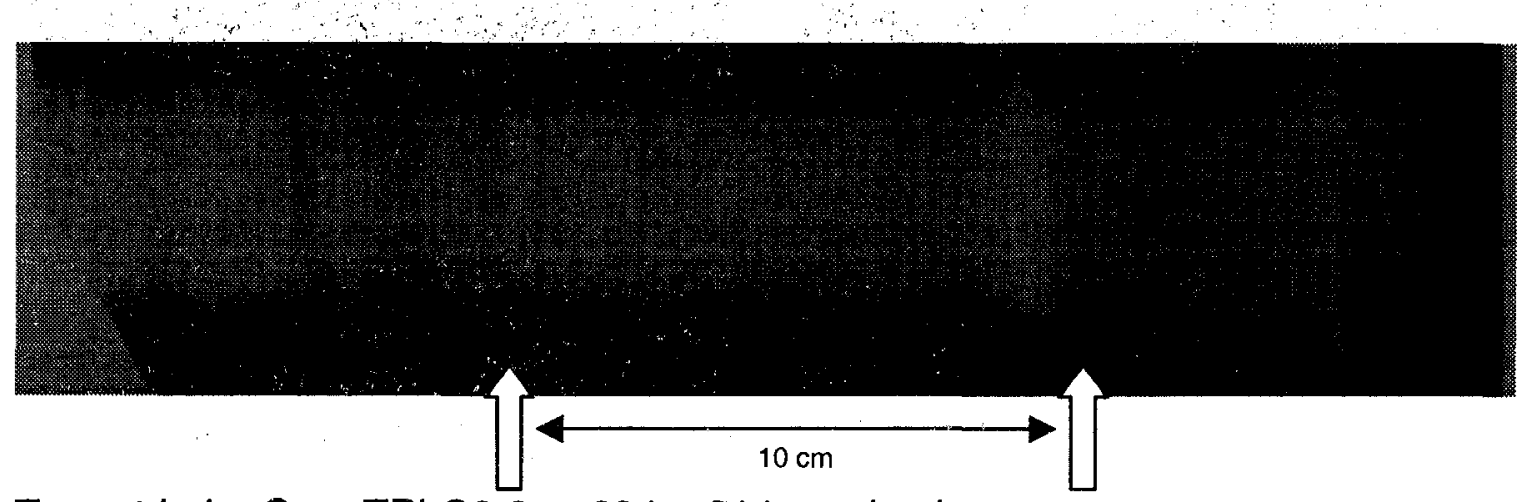

Teapot Lake Core TPLC2-3: 294 - 314 cm depth 


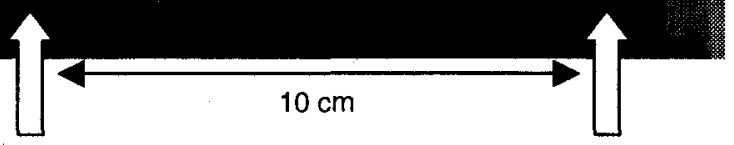

Teapot Lake Core TPLC2-4: $314-334 \mathrm{~cm}$ depth

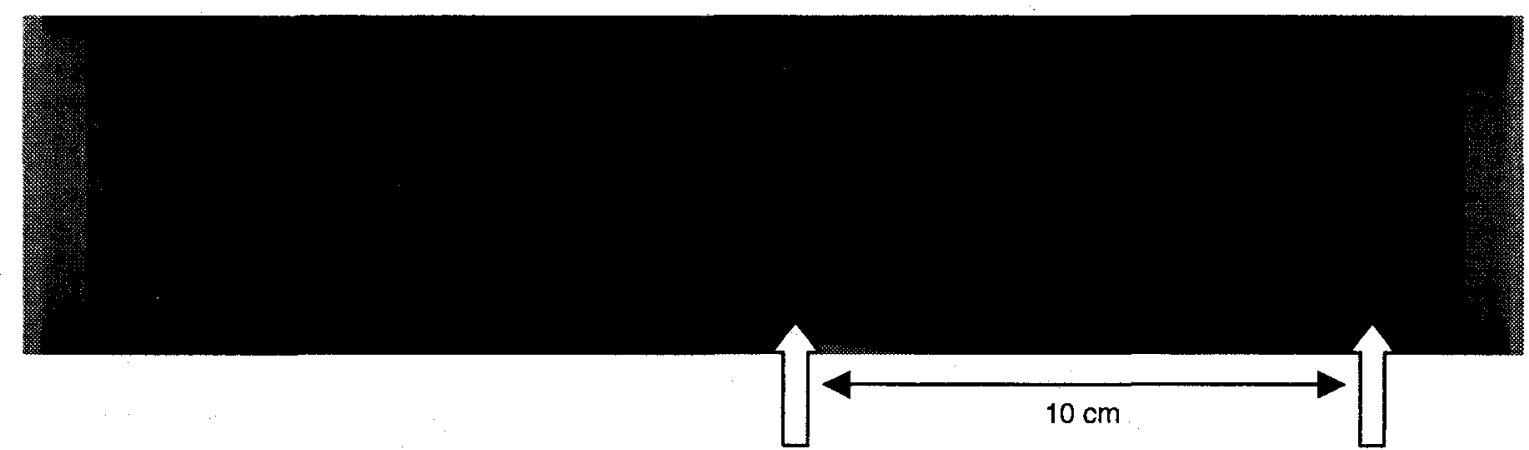

Teapot Lake Core TPLC2-4: $356 \mathrm{~cm}-376 \mathrm{~cm}$ depth

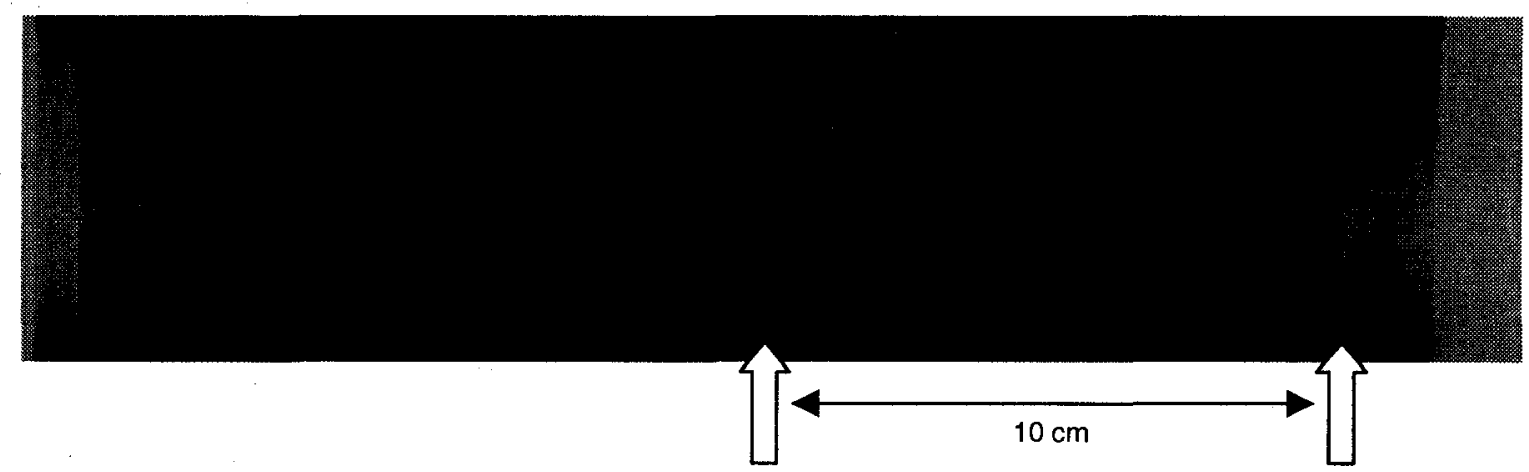

Teapot Lake Core TPLC2-4: 376 - $396 \mathrm{~cm}$ depth 


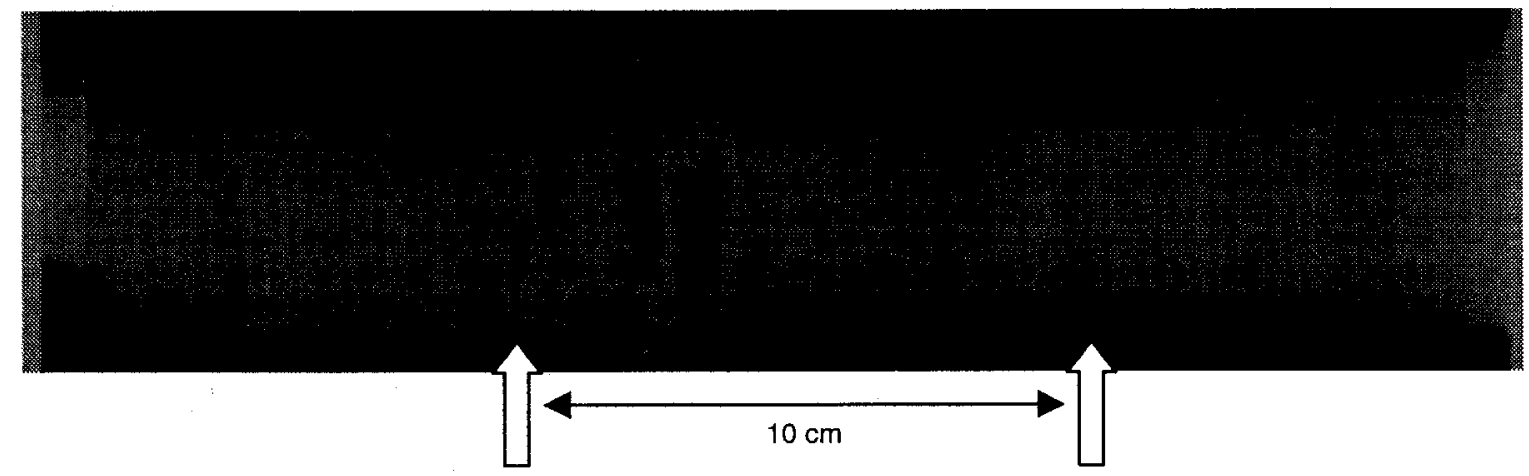

Teapot Lake Core TPLC2-5: 421 - 441 cm depth

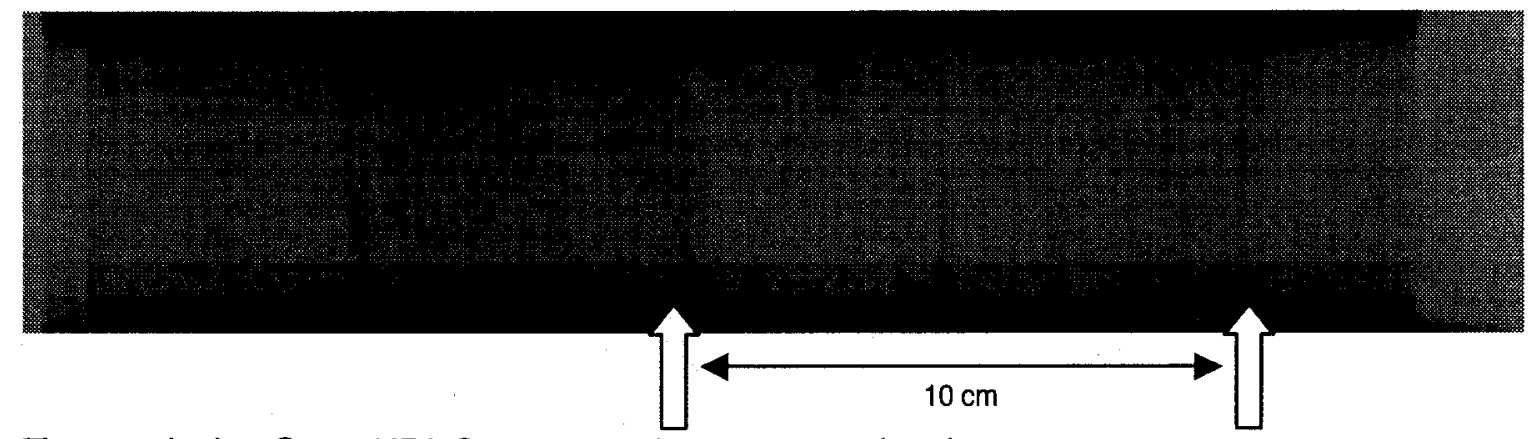

Teapot Lake Core TPLC2-5: 441 - $461 \mathrm{~cm}$ depth

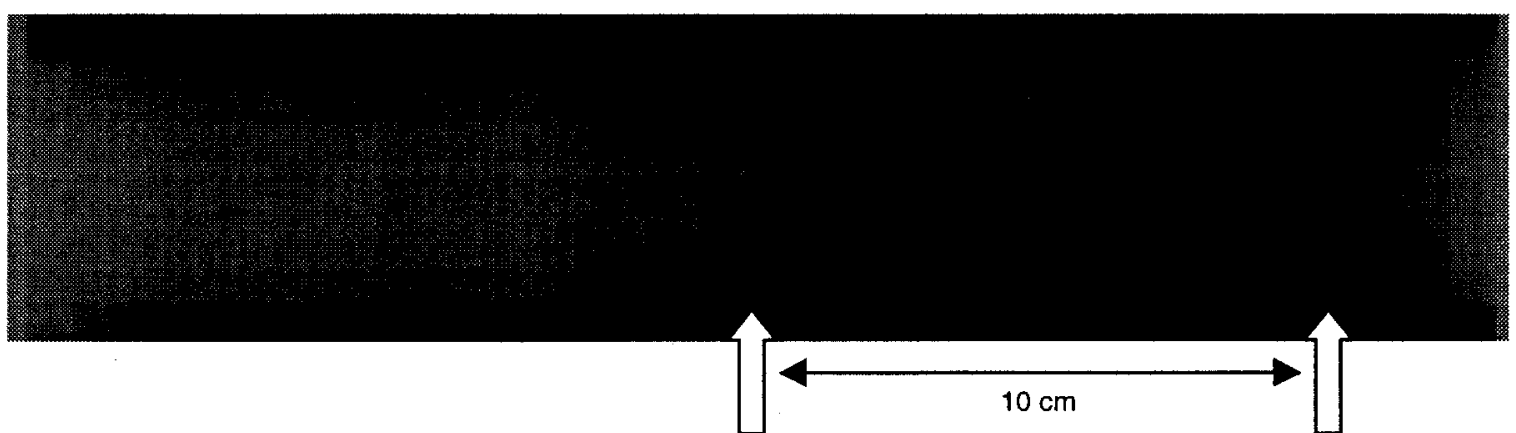

Teapot Lake Core TPLC2-5: $461-481 \mathrm{~cm}$ depth 


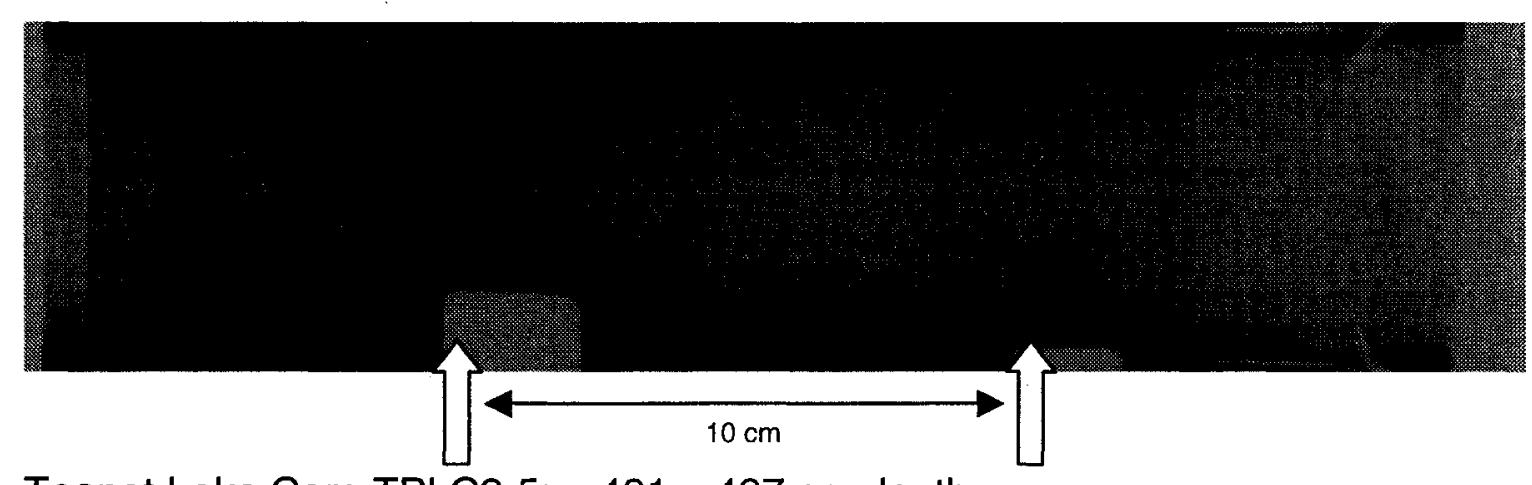

Teapot Lake Core TPLC2-5: $481-497 \mathrm{~cm}$ depth 